SAUL NITSCHE ROCHA

Expressão e secreção de proteínas heterólogas em leveduras do gênero Kluyveromyces 
SAUL NITSCHE ROCHA

\section{Expressão e secreção de proteínas heterólogas em leveduras do gênero Kluyveromyces}

Tese apresentada à Escola Politécnica da Universidade de São Paulo para a obtenção do título de Doutor em Engenharia

Área de concentração: Engenharia Química

Orientador: Prof. Dr. Andreas Karoly Gombert

São Paulo 
Autorizo a reprodução e divulgação total ou parcial deste trabalho, por qualquer meio convencional ou eletrônico, para fins de estudo e pesquisa, desde que citada a fonte.

Este exemplar foi revisado e alterado em relação à versão original, sob responsabilidade única do autor e com a anuência de seu orientador.

São Paulo, 21 de janeiro de 2010.

Assinatura do autor

Assinatura do orientador

FICHA CATALOGRÁFICA

Rocha, Saul Nitsche

Expressão e secreção de proteínas heterólogas em levedu ras do gênero Kluyveromyces marxianus / S.N. Rocha. -- ed.rev. -- São Paulo, 2010.

$179 \mathrm{p}$.

Tese (Doutorado) - Escola Politécnica da Universidade de São Paulo. Departamento de Engenharia Química.

1. Leveduras 2. Metabolismo celular 3. Biologia molecular 4. Enzimas lipolíticas 5. Enzimas oxirredutoras I. Universidade de São Paulo. Escola Politécnica. Departamento de Engenharia Química II. t. 
Às pessoas que eu amo: Carla, João, Kamila, Lucas e Rosa, que me apoiaram incondicionalmente durante os anos de estudos e realização deste trabalho. 


\section{AGRADECIMENTOS}

Aos meus pais João e Rosa e aos meus irmãos Carla e Lucas primeiro por me acompanharem desde o início da minha vida. Depois pelo apoio durante os difíceis anos de estudo, por todo o amor e também pelo apoio emocional e financeiro, quando assim necessitei, tanto em São Paulo quanto na Espanha;

À minha namorada Kamila por todo o amor dispensado e por me acompanhar diariamente durante o período deste trabalho. Agradeço a compreensão e paciência para ficar semanas distante e o pior de tudo, por eu ter ficado um ano afastado do país;

À Cida, Hamilton, Karina, Mário e Zinha por se tornarem minha família "adotiva" que muito me apoiou neste período;

Ao Prof. Dr. Andreas Karoly Gombert, pela orientação, pela amizade e pelo apoio de maneira incondicional, tanto em quesitos técnicos quanto burocráticos. Pelo apoio incessante no pedido de bolsas de estudo no Brasil e no exterior. Pelo conhecimento transmitido e pelo rigor acadêmico com que sempre conduziu este estudo;

Ao Prof. Dr. José Abrahão Neto pela co-orientação extra-oficial deste trabalho e pelas inúmeras sugestões realizadas nesta pesquisa. Também agradeço a amizade e companheirismo partilhados desde o início da Tese;

À Profa. Dra. María Isabel González-Siso que foi de vital importância para o desenvolvimento das pesquisas em biologia molecular. Seu apoio à este trabalho foi intenso e também me apoiou em inúmeros quesitos durante a minha estada em $\mathrm{A}$ Coruña, Espanha;

Aos Professores do Laboratório de Engenharia Bioquímica (LEB) Prof. Dr. Aldo Tonso, Profa. Dra. Beatriz Vahan Kilikian, Profa. Dra. Maria Cândida Reginato Facciotti e Prof. Dr. Pedro de Alcântara Machado, pelo apoio dispensado em inúmeras oportunidades;

À minha amiga Roberta Costa por ter proporcionado a oportunidade de eu conhecer o Prof. Andreas e claro, pela amizade durante esses anos desde a graduação;

Ao meu amigo Thiago Basso pelo incomensurável companheirismo e pela ajuda dispensada em vários experimentos realizados durante este estudo;

Aos meus amigos Angel Pereira e Rafael Fernández, pelo companheirismo, amizade e pelo acolhimento dispensado durante minha estada na Espanha;

Aos companheiros de laboratório em São Paulo: Andréa, Bianca, Bruno, Daniela, Felipe, Gustavo, lara, Mariana, Marcelo, Olavo, Orlinda, Paula, Teresa, Zé Paulo pelo companheirismo e amizade;

Aos companheiros de laboratório na A Coruña: Aida, Ana García, María del Pilar, Marcos e Olalla e Raquel, pelo respeito e acolhimento demonstrados;

Aos meus amigos não citados, porém não esquecidos; 
À Universidade de São Paulo (USP) pela oportunidade de realização do curso de doutorado;

Ao Laboratório de Engenharia Bioquímica da USP por colocar a disposição a área experimental e o laboratório;

Ao Laboratório de Bioquímica e Bioloxía Molecular da UDC por colocar a disposição a área experimental e o laboratório;

À Fundação de Amparo à Pesquisa do Estado de São Paulo, pela concessão da bolsa de doutorado e pelo apoio financeiro para a realização desta pesquisa;

Ao Conselho Nacional de Desenvolvimento Científico e Tecnológico (CNPq), pelo apoio financeiro para a realização desta pesquisa;

À Coordenação de Aperfeiçoamento de Pessoal de Nível Superior (Capes), pela concessão de bolsa e viagem para desenvolvimento de parte do trabalho na Universidade da Coruña;

À Xunta de Galícia, pelo apoio financeiro para a realização desta pesquisa na Espanha. 


\section{RESUMO}

ROCHA, S. N. Expressão e secreção de proteínas heterólogas em leveduras do gênero Kluyveromyces. 2010. Tese (Doutorado) - Escola Politécnica, Universidade de São Paulo, São Paulo, 2010.

A levedura Kluyveromyces marxianus, apesar de apresentar propriedades fisiológicas vantajosas para a produção heteróloga de proteínas, foi utilizada apenas poucas vezes como hospedeira na síntese dessa classe de moléculas. Em contrapartida, a sua congênere Kluyveromyces lactis possui mais de 40 sistemas de expressão desenvolvidos, inclusive comerciais. Além disso, não há literatura disponível sobre glicosilação de proteínas em $K$. marxianus. Levando-se isso em consideração, este trabalho visou a desenvolver sistemas para a expressão heteróloga da enzima glicose oxidase (GOX) de Aspergillus niger e de uma esterase termófila (EST) de Thermus thermophilus em K. marxianus. A linhagem $K$. lactis CBS 2359 foi utilizada como parâmetro de comparação em todos os sistemas de expressão construídos. Primeiramente, foi realizado um estudo fisiológico com a finalidade de selecionar, dentre três linhagens de $K$. marxianus pré-selecionadas a partir de informação da literatura, a que apresentasse as melhores características fisiológicas para se tornar uma hospedeira de expressão heteróloga. A linhagem selecionada foi a CBS 6556, baseando-se numa combinação das seguintes características: velocidade específica de crescimento, formação de metabólitos, rendimento de substrato em biomassa e secreção da enzima homóloga inulinase. Após, foram construídos dois sistemas de expressão epissomais. No primeiro, o gene era expresso sob controle do promotor PGK de $S$. cerevisiae e no segundo, sob controle de INU1 de K. marxianus. Um sistema integrativo foi utilizado, no qual a expressão era dirigida pelo promotor INU1. Estudos bioquímicos e de glicosilação foram realizados nas enzimas produzidas. Em relação aos sistemas para expressão de GOX, foram alcançados níveis de produção de 1722 U/gMS (unidades por grama de biomassa seca) em $K$. marxianus transformado com o sistema epissomal no qual a expressão era controlada pelo promotor INU1. As caracterizações bioquímicas da enzima mostraram que a molécula produzida apresentava propriedades 
semelhantes à enzima homóloga de $A$. niger. Além disso, os estudos de glicosilação mostraram uma menor tendência de hiperglicosilação de $K$. marxianus quando comparada com $K$. lactis. Já em relação à esterase, $K$. lactis apresentou maiores níveis de expressão (294 U/gMS), porém a enzima produzida em K. marxianus apresentou temperatura ótima de atividade $\left(50{ }^{\circ} \mathrm{C}\right)$ ligeiramente superior à enzima produzida por sua congênere $\left(45^{\circ} \mathrm{C}\right)$, temperaturas abaixo da qual ocorre maior atividade da enzima homóloga $\left(65^{\circ} \mathrm{C}\right)$. Isso pode ser explicado pela glicosilação exercida por ambas espécies de leveduras sobre a proteína, ao contrário da homóloga, não glicosilada. Além disso, os produtos das leveduras apresentaram três padrões de glicosilação. Dessa forma, o trabalho desenvolvido alcançou seu objetivo de desenvolver esses sistemas de expressão, bem como de avaliar a síntese heteróloga de proteínas nessa levedura de destacado potencial. Os resultados obtidos devem servir à comunidade científica, no sentido de estimular e orientar futuros trabalhos que objetivem a síntese heteróloga de proteínas em microrganismos.

Palavras-chave: Kluyveromyces marxianus, Kluyveromyces lactis, expressão heteróloga, glicose oxidase, esterase, glicosilação 
ABSTRACT

ROCHA, S. N. Expression and secretion of heterologous proteins in Kluyveromyces yeasts. 2010. Tese (Doutorado) - Escola Politécnica, Universidade de São Paulo, São Paulo, 2010.

In spite of the advantageous physiological properties of the yeast Kluyveromyces marxianus to produce heterologous proteins, this species has not been widely explored for the synthesis of these biomolecules. On the other hand, more than 40 heterologous expression systems, including commercial ones, were developed for Kluyveromyces lactis. Moreover, there is no available literature concerning heterologous protein glycosylation in K. marxianus. Taking these facts into account, this work aimed at developing systems for the heterologous production of Aspergillus niger glucose oxidase (GOX) and of a thermophilic esterase (EST) from Thermus thermophilus in K. marxianus. The strain K. lactis CBS 2359 was utilized as a reference throughout the whole work. First, a physiological study was carried out in order to select one K. marxianus strain, out of three which had been chosen based on literature information, that exhibited the best physiological traits to be a heterologous expression host. The chosen strain was CBS 6556, based on a combination of the following properties: specific growth rate, metabolites formation, biomass yield on substrate, and secretion of the homologous enzyme inulinase. Subsequently, two episomal systems were constructed. In one of them, the heterologous gene was expressed under control of the S. cerevisiae PGK promoter, whereas in the other system, heterologous gene expression occurred under control of the K. marxianus INU1 promoter. An integrative expression system was also constructed, in which the KmINU1 promoter drove foreign gene expression. Both heterologous enzymes were characterized biochemically and also with respect to their glycosylation. The results attained with GOX led to an expression level of 1722 U/g DW (unit per gram of dry cell weight) in $K$. marxianus transformed with the episomal INU1-based system. The biochemical studies showed that the enzyme was very similar to the $A$. niger GOX. Furthermore, analysis of the glycosylation pattern showed a lower tendency of $K$. marxianus to hypermannosylate proteins, when 
compared to K. lactis. Higher levels of esterase (294 U/gDW) were obtained in $K$. lactis than in K. marxianus. However, the enzyme produced in the latter host presented a higher temperature for maximal activity $\left(\left(50^{\circ} \mathrm{C}\right)\right.$, when compared to the former organism $\left(45^{\circ} \mathrm{C}\right)$. Both values are lower than the temperature for maximal activity of the homologous enzyme $\left(65^{\circ} \mathrm{C}\right)$, which can be explained by the glycans added by both yeast species to the peptide, resulting in a glycosylated protein, in contrast to the homologous esterase. Moreover, the yeast products presented three glycosylation patterns. In conclusion, the work presented in this thesis reached its aims, which were to develop these expression systems and to characterize biochemically the heterologous enzymes expressed, which included an analysis of the glycosylation pattern. The results presented here will certainly be of interest and aid the scientific community working on the expression of heterologous proteins in microorganisms.

Keywords: Kluyveromyces marxianus, Kluyveromyces lactis, heterologous expression, glucose oxidase, esterase, glycosylation. 


\section{LISTA DE ABREVIATURAS E SIGLAS}

\begin{tabular}{|c|c|}
\hline${ }^{\circ} \mathrm{C}$ & Graus Celsius \\
\hline Asn & Asparagina \\
\hline Asp & Ácido Aspártico \\
\hline C-mmol & Milimol de carbono \\
\hline C-mol & Mol de carbono \\
\hline CDS & coding sequence (seqüência codificadora do gene) \\
\hline DNA & Ácido desoxirribonucléico \\
\hline DSB & Double-strand break mechanism \\
\hline EST & Esterase \\
\hline FAD & Flavina-adenina dinucleotídeo \\
\hline FDA & Food and Drug Administration \\
\hline g GLC & Grama de glicose \\
\hline g LAC & Grama de lactose \\
\hline g MS & Grama de biomassa seca \\
\hline g SUC & Grama de sacarose \\
\hline$g, m g, \mu g, n g$ & Grama, miligrama, micrograma, nanograma \\
\hline Gal & Galactose \\
\hline Glc & Glicose \\
\hline GlcNAc & N-acetil-glicosamina \\
\hline Glu & Ácido Glutâmico \\
\hline Gly & Glicina \\
\hline GOX & Glicose oxidase \\
\hline GRAS & Generally Recognized As Safe \\
\hline $\mathrm{h}$ & hora \\
\hline His & Histidina \\
\hline HR & Homologous recombination \\
\hline $\mathrm{kDa}$ & Quilo Daltons \\
\hline$K m G A P D H$ & Promotor GAPDH de Kluyveromyces marxianus \\
\hline KmINU1 & Promotor INU1 de Kluyveromyces marxianus \\
\hline $\mathrm{L}, \mathrm{mL}, \mu \mathrm{L}$ & Litro, mililitro, microlitro \\
\hline
\end{tabular}




\begin{tabular}{|c|c|}
\hline $\mathrm{m}, \mathrm{mm}, \mu \mathrm{m}, \mathrm{nm}$ & Metro, milímetro, micrômetro, nanômetro \\
\hline Man & Manose \\
\hline mg Prot & Miligrama de proteína \\
\hline $\min$ & Minuto \\
\hline mmol, $\mu \mathrm{mol}$ & Milimol, micromol \\
\hline mRNA & RNA mensageiro \\
\hline NANA & ácido $N$-acetilneuramínico \\
\hline NHEJ & Non-homologous end joining \\
\hline PCR & Polymerase Chain Reaction \\
\hline Pro & Prolina \\
\hline rDNA & DNA recombinante \\
\hline RNA & Ácido ribonucleico \\
\hline ScADH & Promotor $A D H$ de Saccharomyces cerevisiae \\
\hline ScPGK & Promotor PGK de Saccharomyces cerevisiae \\
\hline ScTDH3 & Promotor TDH3 de Saccharomyces cerevisiae \\
\hline Ser & Serina \\
\hline Thr & Treonina \\
\hline Tyr & Tirosina \\
\hline$U$ & Unidade de atividade enzimática \\
\hline UDP & Uridine diphosphate \\
\hline UPR & Unfolded protein response \\
\hline W & Watts \\
\hline$\times g$ & Vezes a força da gravidade \\
\hline Xaa & Qualquer aminoácido \\
\hline$Y_{X / S}{ }^{E X P}$ & $\begin{array}{l}\text { Conversão de biomassa a células na fase exponencial de } \\
\text { crescimento microbiano }\end{array}$ \\
\hline$Y_{X / S}^{G L O}$ & Conversão global de biomassa a células \\
\hline
\end{tabular}




\section{SUMÁRIO}

Introdução

14

Capítulo 1 - Revisão Bibliográfica 19

Capítulo 2 - Diversidade Fisiológica na Espécie Kluyveromyces marxianus 43

Capítulo 3 - Construção de sistemas de Expressão Heteróloga em Kluyveromyces marxianus e Kluyveromyces lactis 65

Capítulo 4 - Expressão Heteróloga da Glicose Oxidase de A. niger em Kluyveromyces marxianus 101

Capítulo 5 - Expressão Heteróloga de uma Esterase Termofílica em Kluyveromyces marxianus 124

Conclusões 145

Referências Bibliográficas 149

Apêndices 166 
Introdução 


\section{Apresentação}

A produção de proteínas de alto valor comercial, para aplicações diversas como saúde humana, saúde animal e catálise enzimática, entre outras, vem sendo cada vez mais conduzida através da inserção e expressão dos respectivos genes codificadores em hospedeiros como bactérias, leveduras, bolores, células animais em cultura, plantas ou mesmo em animais inteiros.

Cada um dos sistemas de expressão acima possui vantagens e desvantagens, mas na maioria dos casos procura-se sempre empregar o sistema mais simples, desde que seja possível obter as proteínas com sua devida conformação e funcionalmente ativas. Devido à facilidade de cultivo e ao baixo custo envolvido, as bactérias são os sistemas mais simples. No entanto, proteínas de mamíferos que apresentam estruturas muito complexas e que exigem várias modificações póstraducionais não são corretamente geradas em bactérias, pois as mesmas não possuem a maquinaria enzimática necessária para promover estas modificações. Nestes casos, o sistema de expressão a ser empregado tem que ser mais complexo.

De modo geral, as leveduras situam-se numa posição intermediária entre as bactérias e as células animais, como sistema de expressão. Elas são capazes de promover algumas das modificações pós-traducionais exigidas para a correta conformação de algumas proteínas de mamíferos. Além disto, apresentam características de cultivo e velocidades de crescimento similares às bactérias. Em contraste, as células de animais têm exigências muito mais complexas de cultivo e velocidades de crescimento muito mais baixas se comparadas a microrganismos, mas são capazes de promover as modificações pós-traducionais necessárias à correta conformação das proteínas com estruturas mais complexas.

Outra questão importante envolvida na escolha de um sistema de expressão é a purificação do produto de interesse. Enquanto as leveduras são mais dificilmente rompidas do que as bactérias, no caso de um produto intracelular, é mais fácil direcionar o produto de interesse para o meio extracelular nas leveduras, inserindose uma seqüência sinal adequada a montante do gene que codifica para a proteína heteróloga a ser sintetizada. Isto pode ser muito conveniente, pois no caso do produto ser formado no ambiente extracelular, evita-se o rompimento das células nas primeiras etapas de purificação, o que tornaria a separação do produto de 
interesse das moléculas contaminantes muito mais complexa.

Várias linhagens da levedura Kluyveromyces marxianus vêm sendo utilizadas em estudos fisiológicos no Laboratório de Engenharia Bioquímica do Departamento de Engenharia Química da Escola Politécnica da USP, desde o início da década de 2000, com o principal objetivo de estudar o metabolismo de carbono nesta espécie, que difere da espécie Saccharomyces cerevisiae principalmente quanto à utilização preferencial da via respiratória de obtenção de energia, sobre a fermentativa. Inicialmente, foram estudadas a produção de etanol e as atividades das enzimas em torno da glicose-6-fosfato, após choque de açúcar, na linhagem K. marxianus CBS 6556 (Bellaver, 2003). Mais tarde, foi estudado o consumo de substrato durante o crescimento desta mesma espécie em misturas de açúcares (de Carvalho, 2005 e Fonseca, 2007). Subseqüentemente, foi realizada uma análise de fluxos metabólicos nesta mesma linhagem, demonstrando a predominância do metabolismo respiratório e a alta capacidade de conversão de substrato em biomassa desta espécie de $K$. marxianus (Fonseca, 2007). Em paralelo, investigou-se o metabolismo da linhagem K. marxianus NRRL y2415, que possui tendência em crescer na forma de pseudohifas (Suárez-Castillo, 2005). No presente trabalho, as linhagens K. marxianus CBS 6566, CBS 712 e CBS 397, foram estudadas quanto a parâmetros da sua fisiologia relevantes para a expressão de proteínas heterólogas. A linhagem que apresentou as melhores características para esta finalidade foi empregada para a inserção de construções genéticas, com o objetivo de promover a expressão de duas proteínas heterólogas: glicose oxidase e esterase. A primeira foi escolhida por ser uma proteína amplamente estudada e por já ter sido expressa em diferentes sistemas heterólogos. A segunda é uma proteína pouco estudada, mas de potencial aplicação na produção de biodiesel. A levedura K. lactis CBS 2359 foi empregada como referência durante todo este trabalho, por ser uma levedura amplamente estudada e com muita informação disponível na literatura, o que não é o caso de $K$. marxianus.

Esta tese de doutoramento está dividida em capítulos. O primeiro capítulo apresenta uma revisão da literatura relevante a este trabalho. Nos capítulos subseqüentes, apresenta-se as diferentes etapas do trabalho na forma de artigo científico, ou seja, após uma breve introdução, apresentam-se os métodos, resultados e discussão. Dessa forma, no segundo capítulo está descrita a primeira etapa do trabalho, que consistiu no estudo fisiológico de diferentes linhagens de $K$. marxianus e comparação com $K$. lactis. No terceiro capítulo encontra-se o 
detalhamento do desenvolvimento das construções de DNA utilizadas para a expressão heteróloga. Já o quarto capítulo contempla os resultados obtidos com a expressão da glicose oxidase, tanto em termos de produção, quanto em relação às características bioquímicas da enzima. Por fim, no último capítulo está descrito o trabalho realizado com a produção e análise bioquímica da esterase de Thermus thermophilus.

A produção científica referente a este doutoramento está relacionada a seguir:

ROCHA, S. N.; GOMBERT, A. K. Selection of Kluyveromyces strains for the production of heterologous proteins. In: Simpósio Nacional de Bioprocessos (SINAFERM), 2007, Curitiba. Anais do XVI SINAFERM, 2007.

GUIMARAES, M. R. F.; ROCHA, S. N. ; TONSO, A.; GOMBERT, A. K. Fisiologia de Leveduras Industriais e de Laboratório em Cultivos Descontínuos. In: Simpósio Nacional de Bioprocessos (SINAFERM), 2007, Curitiba. Anais do XVI SINAFERM, 2007.

ROCHA, S. N.; Cerdán, M.E.; González-Siso, M.I.; GOMBERT, A. K. Heterologous Protein Production in Different Kluyveromyces Strains. In: 5th Conference on Recombinant Protein Production, 2008, Alghero. Abstracts of the 5th Conference on Recombinant Protein Production, 2008.

ROCHA, S. N.; ABRAHAO-NETO, J.; González-Siso, M.I.; Cerdán, M.E.; GOMBERT, A. K. Heterologous protein expression in Kluyveromyces marxianus. In: 27th ISSY Yeasts for health and biotechnologies, 2009, Paris. Abstracts of the 27th ISSY Yeasts for health and biotechnologies. Paris : Institute Pasteur, 2009.

ROCHA, S. N.; ABRAHAO-NetO, J.; GOMBERT, A. K. Physiologycal diversity within the Kluyveromyces marxianus species. Artigo submetido a uma revista internacional.

ROCHA, S. N.; ABRAHAO-NETO, J.; González-Siso, M.I.; Cerdán, M.E.; GOMBERT, A. K. Heterologous expression of glucose oxidase in the yeast Kluyveromyces marxianus. Artigo aceito para publicação na revista Microbial Cell Factories. 
ROCHA, S. N.; ABRAHAO-NETO, J.; González-Siso, M.I.; Cerdán, M.E.; GOMBERT, A. K. Heterologous expression of thermophilic esterase in the yeast Kluyveromyces marxianus. Artigo a ser submetido a uma revista internacional.

\section{Objetivos}

Este trabalho teve como objetivo geral avaliar a capacidade da levedura Kluyveromyces marxianus em servir de hospedeira para a síntese de proteínas heterólogas.

Os objetivos específicos foram os seguintes:

1. Selecionar uma linhagem de $K$. marxianus que possuísse características fisiológicas favoráveis ao uso em cultivos a altas concentrações celulares, mais especificamente um alto rendimento de conversão de substrato a biomassa e baixa tendência em formar subprodutos não vinculados à biomassa celular, além de uma alta capacidade de expressão e secreção de uma proteína homóloga, a inulinase, que tem alto peso molecular e glicosilações;

2. Desenvolver sistemas de expressão e secreção para as seguintes proteínas em K. marxianus: glicose oxidase (GOX) de Aspergillus niger e esterase de Thermus thermophilus. Isso foi realizado através da inserção de fragmentos de DNA (seqüência promotora - seqüência sinal de secreção - gene heterólogo seqüência terminadora) em plasmídeos com capacidade de auto-replicação nesta levedura e também em sistemas integrativos. Inserir as mesmas construções genéticas na linhagem $K$. lactis CBS 2359, para comparar os níveis de expressão das proteínas heterólogas nas duas espécies;

3. Realizar cultivos com as linhagens obtidas acima, a fim de se avaliar os níveis de expressão atingidos com cada construção genética, para as duas proteínas e as duas leveduras estudadas, além de determinar as características bioquímicas principais das proteínas heterólogas, incluindo os níveis de glicosilação aplicados às mesmas por ambas as leveduras. 
Capítulo 1

\section{Revisão Bibliográfica}




\section{Uso da levedura K. marxianus para a síntese de proteínas heterólogas}

A produção de altos níveis de proteínas através de organismos geneticamente modificados é uma alternativa à extração dessas moléculas de fontes naturais. Estas fontes, além de serem limitadas, normalmente produzem proteínas em pequenas concentrações, o que pode tornar o processo de extração economicamente inviável. Dessa forma, com um processo capaz de produzir proteínas a altas concentrações e preferencialmente de forma que as mesmas sejam facilmente isoladas (como no sobrenadante do cultivo), pode-se ganhar em rendimento na etapa de purificação.

Com o desenvolvimento de técnicas de biologia molecular na década de 1970, surgiram as primeiras perspectivas de utilizar leveduras como hospedeiras na síntese de proteínas heterólogas. A tecnologia de DNA recombinante (rDNA) permite a produção de uma ampla gama de peptídeos e proteínas a partir de células que naturalmente não os produzem. Os primeiros produtos de origem biotecnológica oferecidos no mercado mundial a partir da tecnologia de rDNA foram produtos farmacêuticos (insulina, interferons, eritropoietina) e enzimas industriais (para o beneficiamento de alimentos, fabricação de detergentes e papel) (Porro et al., 2005).

A bactéria Escherichia coli até o presente momento é o organismo mais amplamente utilizado como hospedeiro na síntese heteróloga de proteínas. Isso se deve ao fato de que há um grande volume de informações de alta qualidade que dizem respeito à sua genética, metabolismo, fisiologia e tecnologia de fermentação. Porém, existem limitações práticas no uso de bactérias que impedem a utilização desses microrganismos como hospedeiros em algumas situações. As principais delas são: a falta de capacidade de processar o peptídeo recém traduzido corretamente e também, em muitos casos, o fato de que as proteínas expressas são concentradas em corpos de inclusão intracelulares, muitas vezes causando perda da estrutura tridimensional e de atividade enzimática (no caso de enzimas). Como resultado, o uso de proteínas com estrutura incorreta em humanos não é possível, a não ser que a mesma seja re-editada in vitro, como ocorre no caso de grande parte da insulina produzida comercialmente (Hamilton e Gerngross, 2007). 
Entre os sistemas de hospedeiros microbianos eucarióticos, as leveduras combinam as vantagens de organismos unicelulares (i.e., a facilidade de manipulação genética e de crescimento submerso) com a capacidade de processamento de proteínas típica de organismos eucarióticos (i.e., organização da estrutura tri-dimensional e edições pós-traducionais), em conjunto com a ausência de endotoxinas bem como de DNA oncogênico ou viral (Porro et al., 2005).

A partir da primeira menção da transformação de Saccharomyces cerevisiae com um plasmídeo autônomo (Beggs, 1978), surgiu um amplo campo de estudo para a expressão de proteínas heterólogas nesta espécie. A levedura Saccharomyces cerevisiae começou a ser utilizada a partir do final do século passado para a produção heteróloga de proquimosina (Goff et al., 1984) e a-amilase (Sakai et al., 1988). Atualmente, continua sendo utilizada em diversas aplicações, como produção de vacinas (Antoniukas et al., 2006; Parolin et al., 2005) e produção de anticorpos (Thomassen et al., 2005; Miller et al., 2005).

No entanto, as características fisiológicas da Saccharomyces cerevisiae não são em todos os aspectos favoráveis para a sua aplicação na produção industrial de proteínas heterólogas. Por exemplo, S. cerevisiae apresenta característica Crabtreepositiva, o que afeta o gerenciamento de um processo fermentativo industrial, tornando-o muito delicado o controle do mesmo, já que variações mínimas na relação entre substrato e oxigênio ideal levam a uma baixa no rendimento de substrato em biomassa. Esse baixo rendimento é devido à formação de metabólitos extracelulares, como o etanol.

Dentre as mais de 700 espécies conhecidas de leveduras (Kurtzman e Fell, 1998), deve haver algumas que sejam mais versáteis do que $S$. cerevisiae (Rouwenhorst, 1988; Buckholz e Gleeson, 1991; Dominguez et al., 1998). Além disso, as proteínas produzidas em $S$. cerevisiae são muitas vezes hiperglicosiladas e a retenção dos produtos no espaço periplásmico é freqüentemente observada (Porro et al., 2005).

A escolha da levedura hospedeira para a síntese de uma proteína heteróloga é de suma importância para o sucesso de um processo biotecnológico. Na literatura, as leveduras costumam ser classificadas de duas formas: (1) convencionais ou nãoconvencionais e (2) Crabtree-positivas (preferencialmente fermentadoras) ou 
Crabtree-negativas (preferencialmente respiradoras). Dentro desta classificação, $S$. cerevisiae é a única levedura convencional e umas das poucas Crabtree-positivas. O espectro de hospedeiros alternativos à $S$. cerevisiae pode variar entre diversas espécies de leveduras. Entre elas, a Pichia pastoris, que além de ser Crabtreenegativa pode permitir a expressão heteróloga regulada pelo promotor $A O X 1$, induzido na presença de metanol (Macauley-Patrick et al., 2005). Outra alternativa seria a Yarrowia lipolytica, que além de ser heterotálica, possui capacidade destacada de secreção de proteínas homólogas (Madzak et al., 2004). A levedura Hansenula polymorpha, assim como a Pichia pastoris, é metilotrófica Crabtreenegativa (Gellissen \& Hollenberg, 1997; Stasyk et al., 2008). Já Zygosaccharomyces bailli possui vantagens de crescer a altas temperaturas e pressões osmóticas elevadas (Branduardi et al., 2004). Por fim, Kluyveromyces lactis, apresenta a versatilidade de crescer em lactose e de ser Crabtree-negativa, o que pode ser interessante na síntese de proteínas heterólogas (Merico et al., 2004).

Para que uma determinada linhagem de levedura seja passível de utilização como hospedeira da síntese de uma proteína heteróloga, alguns requisitos devem ser atendidos, sendo os principais os seguintes (Hensing et al., 1995):

1. Possibilidade de cultivo em biorreator a altas concentrações celulares;

2. Alta capacidade de conversão de substrato em biomassa (baixa tendência em desviar o fluxo de carbono para a síntese de produtos que não fazem parte da biomassa celular);

3. Possibilidade de expressão do gene heterólogo dissociada do crescimento;

4. Boa capacidade de secreção de proteínas e de realizar edições pós-traducionais;

5. Ser GRAS (Generally Recognized As Safe).

Leveduras do gênero Kluyveromyces costumam atender aos requisitos necessários para um bom organismo de expressão heteróloga. Dentre as espécies deste gênero, $K$. lactis é até o momento a mais estudada para tal finalidade, sendo que o primeiro sistema de transformação descrito nessa levedura foi desenvolvido por Das e Hollenberg (1982). O desenvolvimento de um vetor de transformação abriu a possibilidade de se construir um sistema de expressão, como realizado por 
Van den Berg et al. (1990) para o uso comercial na produção de quimosina bovina. Segundo Van Ooyen et al. (2006), essa proteína foi a primeira enzima heteróloga originada de um eucarioto superior que foi produzida a baixo custo e o processo desenvolvido para a produção dessa enzima em larga escala foi amplamente reconhecido como um grande avanço biotecnológico.

Como hospedeira para a produção heteróloga de proteínas, $K$. lactis possui algumas vantagens sobre outros sistemas de expressão. Entre elas, a facilidade na manipulação genética, com a possibilidade de se utilizar tanto vetores epissomais quanto integrativos, e a disposição do genoma totalmente seqüenciado (Dujon, 2004). K. lactis pode ser cultivada a altas concentrações celulares sem que sejam necessárias estratégias complexas de crescimento, devido à sua característica Crabtree-negativa (ou preferencialmente respiradora). Essas vantagens levaram até ao desenvolvimento de um kit comercial para a expressão de proteínas heterólogas nessa espécie. Consiste em um vetor integrativo multicópia, que integra várias cópias do gene de interesse in tandem no promotor LAC4 do gene da $\beta$ galactosidase (New England Biolabs, produto E1000).

Várias proteínas foram expressas por sistemas heterólogos em $K$. lactis (para uma revisão sobre o assunto, ver Van Ooyen et al., 2006). Dentre elas, $\alpha$-amilases (Strasser et al., 1989; Tokunaga et al., 1997) e celulases (Müller et al., 1998). Becerra et al. (2001) construíram um vetor para expressar $\beta$-galactosidase da própria $K$. lactis de maneira constitutiva. Isso levou a levedura produzir ainda mais enzima, além da homóloga produzida. Outros sistemas, por exemplo para a produção de proteínas de interesse farmacêutico, também já foram desenvolvidos para este hospedeiro. Dentre elas, a interleucina 1- $\beta$ (Fleer et al., 1991), interferon $\alpha-$ A (Chen et al., 1992), $\beta$-lactoglobulina (Rocha et al., 1996), lisozima (Iwata et al., 2004) e precursor da insulina (Feng et al., 1997).

K. lactis é atualmente a espécie mais estudada dentre as existentes do gênero Kluyveromyces. Porém, sua congênere $K$. marxianus apresenta várias potenciais aplicações em diversos segmentos da biotecnologia (para uma revisão sobre o assunto, ver Fonseca et al., 2008). Essa levedura é capaz de sintetizar diversos compostos de interesse comercial de forma homóloga. Dentre eles, encontram-se a enzima pectinase (Schwan et al., 1997) que hidrolisa a pectina, 
polissacarídeo derivado da parede celular de células vegetais, formada principalmente de resíduos de ácido galacturônico parcialmente metil-esterificado, unidos por ligação $\alpha-1,4$ (Blanco et al., 1999). Essas enzimas, além de serem amplamente utilizadas na indústria de sucos, também têm seu uso associado a indústrias têxteis, no tratamento do algodão, no tratamento de efluentes industriais e também na indústria de papel (Almeida et al., 2003). Além da aplicação natural da levedura K. marxianus na produção de pectinases, existem diversas possibilidades de utilizá-la na produção de várias outras moléculas. Etschmann et al. (2003) apresentaram a K. marxianus como produtora de 2-feniletanol, composto com acentuado aroma de rosas. Outro produto, bastante estudado em K. marxianus, é a enzima inulinase (Rouwenhorst et al., 1988) (2,1- $\beta$-D-frutanfrutanohidrolase, EC 3.2.1.7), que hidrolisa a ligação $\beta-2,1$ da inulina, a qual é um polímero formado basicamente por frutose, monômero com alto poder edulcorante e normalmente obtido através da isomerização da glicose por processo enzimático. A inulinase é, portanto, uma alternativa para a produção de xaropes de frutose com concentrações acima de 95\% em apenas uma etapa enzimática (Singh et al., 2007). Além da produção de xaropes de frutose, já foi descrita a produção de etanol a partir de inulina por $S$. cerevisiae em uma única etapa (sacarificação e fermentação) (Nakamura et al., 1996). O crescimento de K. marxianus em sacarose é dependente da ação da inulinase, pois esta, apesar de possuir maior especificidade para a inulina, também é capaz de hidrolisar a sacarose (Hensing et al., 1995).

Além disso, K. marxianus possui características fisiológicas importantes que a tornam muito estudada e potencialmente interessante para a síntese de proteínas heterológas. Dentre elas, estão os já citados alto fator de conversão de substrato a células, a baixa tendência de formar subprodutos em aerobiose, e o fato de essa espécie ser reconhecidamente segura. Somado a isso, está o fato de que $K$. marxianus apresentar crescimento altas temperaturas, ser capaz de crescer a altas velocidades específicas e de utilizar um amplo espectro de fontes de carbono.

Das et al. (1984) já notaram na época, dois anos após construir o primeiro vetor de transformação para K. lactis (Das e Hollenberg, 1982), o potencial de sua congênere, na época conhecida como Kluyveromyces fragilis (que atualmente é a Kluyveromyces marxianus), para a produção de proteínas heterólogas, principalmente pelo fato de esta possuir capacidade de crescer em um intervalo 
mais amplo de temperaturas que a primeira. Além dessa característica, muitas de suas linhagens apresentam a capacidade de crescer em lactose, que muitas vezes é utilizada como matéria-prima de baixo custo, sob a forma de soro de leite. Recentemente, Groeneveld et al. (2009) propuseram que K. marxianus é o organismo eucarioto de crescimento mais rápido dentre todos os conhecidos. Essa característica pode ser explorada em processos industriais para a diminuição do tempo da batelada, apesar do fato de altas velocidades específicas exigirem altas taxas de transferência de oxigênio, no caso de cultivos aeróbios (Hensing et al., 1995). Fonseca et al. (2008), dentre outras características, destacam a capacidade de K. marxianus de secretar proteínas, o que é desejável quando é levado em conta o custo de purificação do produto recém sintetizado. Essas virtudes, somadas às já existentes em $K$. lactis que são comuns a $K$. marxianus, fazem com que está última seja, no mínimo, um interessante objeto de investigação para a expressão heteróloga de proteínas.

Após o primeiro sucesso da técnica de transformação de K. marxianus (Das et al., 1984), que aproveitou a técnica de inserção de DNA exógeno em S. cerevisiae descrita por lto et al. (1983), o que realmente possibilitou o avanço nos estudos de expressão heteróloga em $K$. marxianus foi o descobrimento do plasmídeo pKD1 de Kluyveromyces drosophilarum (Falcone et al. 1986). Esse plasmídeo de $4,8 \mathrm{~kb}$ e 1,65 $\mu \mathrm{m}$ possui uma organização similar ao plasmídeo $2 \mu$ (Futcher et al., 1988) do gênero Saccharomyces (Chen et al., 1986), e pode replicar-se em uma variedade de espécies do gênero Kluyveromyces, inclusive K. lactis (Fleer et al., 1991) e K. marxianus (Bergkamp et al., 1993). Em células cultivadas na ausência de pressão seletiva, o plasmídeo pKD1 pode ser mantido em $K$. lactis, porém sua estabilidade depende da linhagem hospedeira (Hensing et al., 1995). Mais recentemente, foi demonstrado que a inserção do gene de resistência à canamicina, do gene URA3 de S. cerevisiae, a origem de replicação de $E$. coli e o gene que confere resistência à ampicilina ao plasmídeo pKD1 resultou em um vetor versátil que pode transformar e ser mantido em K. marxianus CBS 6556 e CBS 712, embora com baixa eficiência de transformação. Dessa forma, plasmídeos baseados no pKD1 tornaram-se a escolha mais comum para inserir seqüências heterólogas de DNA em $K$. marxianus (Fonseca et al., 2008).

Apesar de a técnica de engenharia genética utilizando plasmídeos de 
replicação autônoma ser conveniente, a estabilidade dos plasmídeos após gerações é limitada (Bartkeviciute et al., 2000; Souza Jr e Morais Jr, 2000). Essa instabilidade é fator crucial em processos industriais. Uma alternativa a essa técnica, é a utilização de plasmídeos integrativos.

A integração de fragmentos de DNA num organismo requer a ação de um mecanismo de reparação de cadeia dupla (DSB- double-strand break mechanism). Em Eukarya, dois mecanismos foram identificados: a recombinação homóloga (homologous recombination, HR) que resulta numa integração direcionada e a ligação de extremidades não homólogas (non-homologous end joining, NHEJ) que resulta numa integração casual. As diferenças na eficiência de integração direcionada nos diferentes organismos podem ser explicadas pela maior atividade de um destes mecanismos. A levedura modelo $S$. cerevisiae apresenta um mecanismo de recombinação homóloga extremamente eficiente, resultando numa freqüência de inserção de genes direcionada elevada (perto dos 100\%) e requer apenas 40 pares de bases de homologia ao gene alvo nas extremidades da cassete de inserção (Baudin et al. 1993). No entanto, S. cerevisiae neste aspecto é uma exceção à regra, uma vez que os fungos filamentosos e organismos eucariotos superiores, apresentam na generalidade um sistema de recombinação homóloga ineficiente. Nos caso dos fungos filamentosos, por exemplo, a recombinação homóloga ocorre a muito baixa freqüência (0,1-20\%) e requer a utilização de grandes fragmentos com mais de 2000 pares de base de homologia. A levedura $K$. lactis, próxima de $S$. cerevisiae e de $K$. marxianus, possui um grau intermediário entre fungos superiores e $S$. cerevisiae de recombinação homóloga. Geralmente, com fragmentos de DNA possuindo centenas de pares de bases de homologia, a eficiência da integração homóloga é mais de 50\%, embora alguns casos tenham sido descritos com integração homóloga em menos de 1\% (Zeeman e Steensma, 2003). A ineficiência do sistema de recombinação homóloga dificulta não só a interrupção de genes, dificultando o estudo fisiológico destes organismos, como também dificulta a integração de cassetes de expressão em locais pré-definidos.

Como referido anteriormente, a integração de cassetes de expressão em múltiplas cópias pode ser conseguida de forma aleatória, mas a integração nãodirecionada poderá afetar aspectos essenciais da fisiologia do hospedeiro. Assim, no contexto do desenvolvimento de um sistema de expressão eficiente para $K$. 
marxianus, é importante estudar este aspecto com vista ao desenvolvimento de vetores que integrem os cassetes de expressão em sítios pré-determinados e que não afetem o funcionamento normal da célula. Outro fator relevante é a eficiência da recombinação homóloga. Kooistra et al. (2004) publicaram uma eficiência de 0\% quando as zonas ladeadoras continham apenas $50 \mathrm{pb}$ em $\mathrm{K}$. lactis. No caso em que foram usadas regiões homólogas de 600 pb para a recombinação, a eficiência da mesma saltou para $88 \%$. Em contrapartida, Ribeiro et al. (2007) alcançaram apenas $34 \%$ de eficiência em $K$. marxianus, usando regiões homólogas ainda maiores que a anterior: 723 e 713 pb, indicando que provavelmente a recombinação homóloga é ainda menos eficiente em $K$. marxianus que em $K$. lactis.

A estabilidade dos vetores integrativos é geralmente muito alta (as taxas de perda da integração são freqüentemente menores que $1 \%$ por geração (Hensing et al., 1995). Uma desvantagem que pode ser citada quanto às construções integrativas é o seu baixo número de cópias por célula. Uma alternativa descrita por Pecota et al. (2007) que permite a integração do gene de interesse em múltiplas cópias ao genoma de $K$. marxianus é o emprego de um cassete de seleção reutilizável. Neste caso, o marcador de seleção auxotrófico URA3 (confere capacidade de crescimento de linhagens ura3 em meios desprovidos de uracila) é envolvido a montante e a jusante por duas repetições do gene hisG de Salmonella, formando o cassete URA3 blaster (UB). Esse método também foi usado com sucesso em integrações seqüenciais de genes heterólogos em S. cerevisiae (Lee e Da Silva, 1997) e em K. lactis (Wang et al., 2003).

Além de requerer vetores eficientes, a expressão de genes heterólogos também depende do promotor e eventualmente de uma seqüência sinal de secreção que direcione a proteína sintetizada para o meio externo, o que geralmente facilita o processo de purificação da mesma (Fonseca et al., 2008).

Um promotor clássico, utilizado em expressão de genes heterólogos em leveduras é o PGK (phosphoglycerate kinase) de S. cerevisiae. Esse promotor é constitutivo e provoca alta expressão gênica. Em conjunto com o terminador do mesmo gene e a seqüência sinal $k_{1}$ (da proteína killer) de $K$. lactis, constitui o cassete de expressão do plasmídeo pSPGK1, utilizado neste trabalho.

Já o promotor INU1 de K. marxianus é responsável pelo controle da 
expressão da enzima inulinase nessa espécie. Este promotor contém uma seqüência prepro que confere a sinalização para a secreção da proteína expressada ao meio extracelular. Essa seqüência sinal também já foi aplicada com sucesso na secreção de proteínas heterólogas em S. cerevisiae (Chung et al. 1996), mostrandose mais eficaz do que a seqüência sinal do fator alfa, cuja utilização se encontra generalizada. Além disso, o promotor INU1 é regulado de acordo com a fonte de carbono existente no meio. Não opera na presença de lactose e em contrapartida promove a expressão na presença de sacarose. Dados da literatura sobre a síntese heteróloga de proteínas sob controle do promotor e seqüência prepro INU1, demonstram a obtenção de $60 \mathrm{mg} / \mathrm{L}$ de interferon humano $\alpha-2 a$ no meio extracelular (Cai et al., 2005). Outro estudo realizado por Bergkamp et al., (1993) relata a produção e secreção para o meio extracelular de 150 mg/L de a-galactosidase. Neste mesmo estudo também é destacado que a eficiência de secreção da enzima heteróloga sob controle de INU1 alcançou 99\% (soma das frações do sobrenadante e periplasma).

A Tabela 1.1 resume os sistemas de expressão heteróloga desenvolvidos até o momento em K. marxianus. Deve-se levar em conta que poucos desses trabalhos tinham o intuito único de produzir proteínas em grande quantidade como nos casos dos trabalhos de Bergkamp et al. (1993) e Cai et al. (2005) indicados acima. Nonklang et al. (2008) relatam a expressão de $\alpha$-amilase de $A$. oryzae em $K$. marxianus, porém sem mencionar valores de produção. Outros trabalhos apresentam focos distintos, como por exemplo o de Hong et al. (2007) que, ao expressar celulases em K. marxianus, esperavam aproveitar a capacidade da levedura de crescer a elevadas temperaturas, para produzir etanol a partir de materiais lignocelulósicos. Pecota et al. (2007) objetivaram a construção de um vetor integrativo para a expressão intracelular da enzima lactato desidrogenase, a qual faria com que $K$. marxianus fosse capaz de transformar piruvato em lactato, sendo este o produto almejado. 
Tabela 1.1. Construções realizadas até o momento visando à expressão heteróloga de proteínas em K. marxianus.

\begin{tabular}{|c|c|c|c|c|c|}
\hline Proteína & Fonte & Vetor & Promotor & $\begin{array}{l}\text { Sinal de } \\
\text { secreção }\end{array}$ & Referência \\
\hline$\alpha$-galactosidase & $\begin{array}{l}\text { Cyamopsis } \\
\text { tetragonoloba }\end{array}$ & $\begin{array}{l}\text { pKMGAL3 } \\
\text { (epissomal) }\end{array}$ & KmINU1 & $\begin{array}{l}\text { KmINU1 } \\
\text { pre-pro }\end{array}$ & $\begin{array}{l}\text { Bergkamp et al. } \\
\text { (1993) }\end{array}$ \\
\hline Endopoligalacturonase & K. marxianus & pKPEC1 & KmPEC1 & $K m P E C 1$ & $\begin{array}{l}\text { Siekstele et al. } \\
\text { (1999) }\end{array}$ \\
\hline$\beta$-glucuronidase & E. coli & pKM2/GUS & ScPGK & Intracelular & Ball et al. (1999) \\
\hline $\begin{array}{l}\text { Glyceraldeído-3-fosfato } \\
\text { desidrogenase }\end{array}$ & K. marxianus & pKYES2 & $G A L 1$ & GPD1 & $\begin{array}{l}\text { Almeida et al. } \\
(2003)\end{array}$ \\
\hline$\beta$-glucuronidase & K. marxianus & pTetGus & tet-off & Intracelular & $\begin{array}{l}\text { Pecota et al. } \\
\text { (2005) }\end{array}$ \\
\hline Interferon $\alpha-2 a$ & H. sapiens & pUKD-S-PIT & KmINU1 & Sc $\alpha$-factor & Cai et al. (2005) \\
\hline Lactato desidrogenase & $\begin{array}{l}\text { Bacillus } \\
\text { megaterium }\end{array}$ & $\begin{array}{l}\text { pUB-LDH } \\
\text { (integrativo) }\end{array}$ & ScPGK & Intracelular & $\begin{array}{l}\text { Pecota et al. } \\
\text { (2007) }\end{array}$ \\
\hline Endo- $\beta$-1,4-glucanase & $\begin{array}{l}\text { Thermoascus } \\
\text { aurantiacus }\end{array}$ & $\begin{array}{l}\mathrm{pKmUI} / \mathrm{KmG} \\
\mathrm{AP}-\alpha-e n g 1\end{array}$ & $K m G A P D H$ & Sc $\alpha$-factor & $\begin{array}{l}\text { Hong et al. } \\
(2007)\end{array}$ \\
\hline Celobioidrolase & $\begin{array}{l}\text { Thermoascus } \\
\text { aurantiacus }\end{array}$ & $\mathrm{pEC}$ & $S c A D H$ & Intracelular & $\begin{array}{l}\text { Hong et al. } \\
(2007)\end{array}$ \\
\hline$\beta$-glucosidase & $\begin{array}{l}\text { Thermoascus } \\
\text { aurantiacus }\end{array}$ & pBGL & $K m G A P D H$ & Sc $\alpha$-factor & $\begin{array}{l}\text { Hong et al. } \\
\text { (2007) }\end{array}$ \\
\hline$\alpha$-amilase & A. oryzae & $\begin{array}{l}\text { pRS316 } \\
\text { (integrativo) }\end{array}$ & ScTDH3 & $\begin{array}{l}\text { Não } \\
\text { informado }\end{array}$ & $\begin{array}{l}\text { Nonklang et al. } \\
(2008)\end{array}$ \\
\hline
\end{tabular}

\section{A enzima glicose oxidase}

A glicose oxidase (GOX) (beta-D-glicose:oxigênio-1-oxidoredutase, EC 1.1.3.4) é uma enzima muito bem caracterizada e estudada, geralmente sendo usada como modelo de estudos na área de expressão heteróloga, tanto por ser uma proteína cuja atividade é de fácil quantificação, quanto por apresentar características bioquímicas importantes para se testar a eficiência do sistema heterólogo, como possuir alguns tipos de edições pós traducionais, como pontes dissulfeto e glicosilações.

A enzima catalisa a oxidação da $\beta$-D-glicose em glucona- $\delta$-lactona e a redução concomitante de oxigênio molecular a peróxido de hidrogênio: $\beta$-D-glicose + $\mathrm{O}_{2} \rightarrow$ glucono- $\delta$-lactona $+\mathrm{H}_{2} \mathrm{O}_{2}$. (Frederick et al. 1990). A GOX foi descoberta por Müller (1928) em extratos de $A$. niger e, décadas depois, a enzima foi purificada a partir de espécies de Aspergillus (Swoboda e Massey, 1965) e Penicillium (Kusai et al., 1960). A seqüência de DNA correspondente à enzima originada de A. niger NRRL-3 foi primeiramente descrita por Kriechbaum et al. (1989), seguida por uma extensa caracterização bioquímica e molecular executada por Frederick et al. (1990). A estrutura da enzima, de 1,9 A, foi descrita por Wohlfahrt et al. (1999). 
Estruturalmente, a enzima consiste em duas subunidades de tamanho idêntico ( $75 \mathrm{kDa}$ ) e dois cofatores FAD ligados não-covalentemente. Esses cofatores agem como carreadores de elétrons durante a catálise (Wong et al., 2008) (Figura 1.1). A GOX possui oito pontos possíveis de $N$-glicosilação (Kim et al., 2004). A proteína nativa é glicosilada e apresenta uma porcentagem de carboidrato de 16$25 \%$ (Kohen et al., 1997). Outras propriedades bioquímicas relevantes estão listadas na Tabela 1.2.

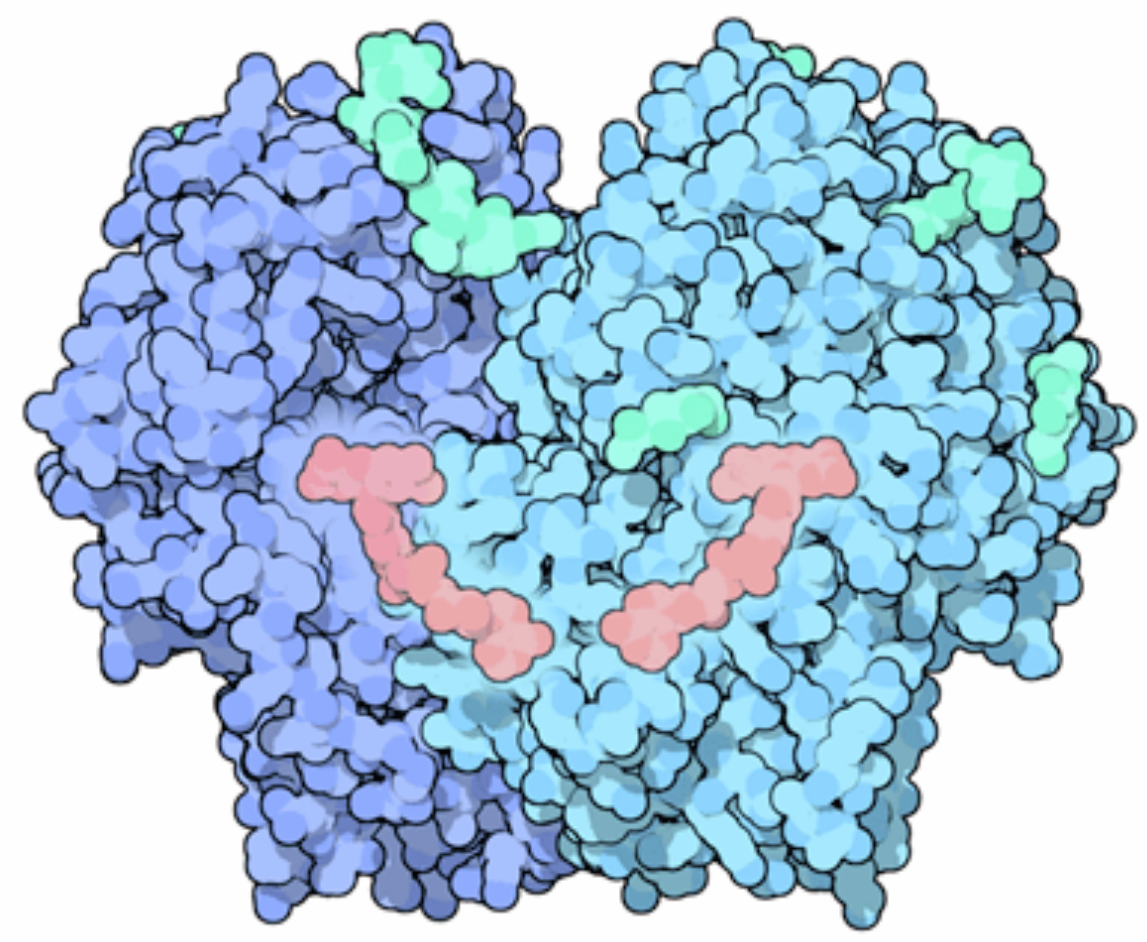

Figura 1.1. Estrutura da glicose oxidase. As subunidades estão representadas em azul claro e azul escuro. Em vermelho, os grupamentos FAD de cada subunidade (Wong et al., 2008)

Tabela 1.2. Propriedades da GOX de A. niger.

\begin{tabular}{|c|c|}
\hline Propriedades & Valores \\
\hline Massa molecular (homóloga, glicosilada) & $\begin{array}{l}186 \mathrm{kDa} \text { (Swoboda e Massey, 1965); } 160 \mathrm{kDa} \text { (Tsuge et } \\
\text { al., 1975; Frederick et al., 1990) }\end{array}$ \\
\hline Massa molecular (homóloga, desglicosilada) & $\begin{array}{l}134 \text { kDa (Frederick et al., 1990); } 136 \text { kDa (Kohen et al., } \\
\text { 1997) }\end{array}$ \\
\hline Absorção UV-Vis (Tsuge et al., 1975) & $\begin{array}{l}280: 380: 450(\mathrm{~nm}) \\
11,5: 1: 1,03 \text { (relação) }\end{array}$ \\
\hline Coeficiente de extinção molar $\left(\mathrm{M}^{-1} \mathrm{~cm}^{-1}\right)$ & 25180 (Swoboda e Massey, 1965) \\
\hline Atividade específica (pH 5.6) & $\begin{array}{l}80 \mu \mathrm{mol} / \mathrm{min} / \mathrm{mg} \text { enzima (Swoboda e Massey, 1965); } \\
172 \mu \mathrm{mol} / \mathrm{min} / \mathrm{mg} \text { enzima (Tsuge et al., 1975) }\end{array}$ \\
\hline $\mathrm{K}_{\mathrm{M}}$ em relação à glicose & $\begin{array}{l}16,4 \mathrm{mM} \text { - pH } 4,5,37^{\circ} \mathrm{C} \text {; Este trabalho } \\
2,56 \mathrm{mM}-\mathrm{pH} 5,5,40^{\circ} \mathrm{C} \text {; Zia et al. }(2007) \\
18 \mathrm{mM}-\mathrm{pH} 5,5,30^{\circ} \mathrm{C} \text {; Mirón et al. }(2002) \\
28 \mathrm{mM}-\mathrm{pH} 4,5,25^{\circ} \mathrm{C} \text {; Kohen et al. (1997) }\end{array}$ \\
\hline pH ótimo & 4-7 (Bao et al., 2001; este trabalho) \\
\hline Ponto Isoelétrico & 4,2 (Ferreira et al., 2005) \\
\hline
\end{tabular}


A produção comercial de glicose oxidase a partir de organismos homólogos pode se tornar um problema, já que, concomitante com a expressão de GOX, vem a expressão de diversas outras enzimas, como a catalase, prejudicando o rendimento do sistema. Para contornar esses problemas, o uso de organismos geneticamente modificados para a expressão da glicose oxidase é fortemente sugerido (Park et al., 2000). Malherbe et al. (2003) exploraram a produção de GOX de A. niger em S. cerevisiae, a fim de permitir que a levedura fosse capaz de diminuir o crescimento de contaminantes na produção de vinho. Os resultados mostraram um alto nível de expressão, de até $126 \mathrm{U} / \mathrm{mL}$. No entanto, a expressão de GOX em S. cerevisiae pode resultar em uma proteína hiperglicosilada, apresentando uma relação de carboidrato de até $60 \%$ da massa total da molécula (Frederick et al., 1990). Outro sistema heterólogo para produção de glicose oxidase foi desenvolvido na levedura metilotrófica Pichia pastoris. A seqüência codificadora da enzima foi isolada de $P$. variabile P16 e a levedura foi capaz de alcançar a produção de $50 \mathrm{U} / \mathrm{mL}$, quatro vezes mais que o valor obtido por expressão homóloga (Crognale et al., 2006). A expressão heteróloga de GOX também foi realizada em E. coli (Witt et al., 1998), porém o resultado não foi expressivo, já que mais de $60 \%$ da proteína expressa estava inativa na forma de corpos de inclusão insolúveis.

Em relação a sua função biológica, a GOX é uma enzima produzida naturalmente por alguns fungos e insetos e sua principal função biológica é a ação antibacteriana e antifúngica, pois é capaz de produzir peróxido de hidrogênio a partir de um substrato comum em meios biológicos: a glicose. Segundo Wong et al. (2008), esse estresse oxidativo permanente é efetivo contra o crescimento de bactérias e fungos, principalmente microrganismos incapazes de agir contra $o$ estresse através, por exemplo, da ação de catalases. Leiter et al. (2004) estudaram o estresse oxidativo gerado pela ação de GOX de $P$. chysogenum sobre diversos microrganismos, observando que o próprio organismo produtor da enzima sofre com a ação da mesma. Entretanto, segundo os autores, há um sensível balanço entre a GOX produzida e a ação antioxidativa da célula, equilíbrio esse que é rompido quando é adicionada subitamente GOX no meio. Outra função da glicose oxidase, descrita em Pleorotus ostreatus (Shin et al., 1993), é a de gerar $\mathrm{H}_{2} \mathrm{O}_{2}$ para degradar lignina, processo no qual é utilizada uma peroxidase extracelular dependente de 
peróxido de hidrogênio. Outra função, descrita na larva do nematóide Helicoperva zea, é a desinfecção do alimento ingerido (Eichenseer et al., 1999).

Em relação à especificidade dos substratos utilizados pela glicose oxidase, esta enzima é capaz de oxidar monossacarídeos, nitroalcanos e compostos hidroxilados (Wilson e Turner, 1992). Considerando a velocidade de reação com Dglicose sendo 100\%, apenas 2-deoxi-D-glicose (20-30\%), 4-O-metil-D-glicose (15\%) e 6-deoxi-D-glicose (10\%) são oxidadas pela GOX a uma taxa significante (Wong et al., 2008). Além do doador de elétrons, que normalmente são moléculas de açúcares, a GOX necessita também de um aceptor de elétrons a fim de que a catálise enzimática seja completada. O aceptor de elétrons natural é o oxigênio dissolvido e é o que fornece maior entalpia à reação quando comparado a outros potenciais aceptores de elétrons como as quinonas (Wong et al., 2008).

Essa enzima possui diversas aplicações como na indústria alimentícia, já que é utilizada como antioxidante e estabilizante, além de ser GRAS (Generally Recognized As Safe) pela classificação do FDA. A GOX pode ser utilizada no transporte e/ou armazenamento do leite cru a fim de conservar o alimento. Ela cria com a enzima lactoperoxidase e o tiocianato, naturalmente presentes no leite 0 sistema da lactoperoxidase (LP). Experimentos demonstram que a vida de prateleira do leite com LP ativo é praticamente o dobro comparado ao alimento com LP inativo (Marks et al., 2001). Há utilização de glicose oxidase também na panificação, já que a enzima é utilizada para aumentar a consistência do glúten através da oxidação de duas proteínas da farinha: a gliadina e a glutenina, a fim de permitir mais ligações na formação do glúten, melhorando a textura do pão. O glúten se forma quando a gliadina e a glutenina estão em contato com água e sua maturação é assistida pela ação de leveduras (Wong et al., 2008). A glicose oxidase também é utilizada na fabricação de farinha de clara de ovo, já que, antes do processo de secagem, a glicose presente é removida a fim de se evitar escurecimento indesejável resultante da reação de Maillard com a albumina presente (Sisak et al., 2006). Além de todas as aplicações alimentícias, a GOX pode ser utilizada na produção de ácido glucônico, o qual é utilizado nas indústrias de tintas de tecidos, limpeza de superfícies metálicas, detergentes, concreto e cosméticos (Yu e Scott, 1997). 
Uma das aplicações da glicose oxidase mais amplamente estudada é a construção de biossensores. Um biossensor pode ser definido como um aparato analítico compacto, o qual incorpora um elemento biológico ou derivado integrado ou intimamente associado com um transdutor físico-químico. O objetivo usual desde aparato é o de produzir um sinal eletrônico, contínuo ou não, que é proporcional à concentração de um único componente (ou mesmo vários) dentro de um meio complexo (Newman e Setford, 2006). Os bioeletrodos amperométricos enzimáticos são muito adequados para auto-testes e monitoramento in vivo da glicemia a partir do sangue. A primeira geração de biossensores de glicose foi normalmente baseada no aprisionamento da glicose oxidase (GOX) entre membranas de diálise seletivas sobre um eletrodo de carbono ou metal usado como transdutor. Ocorre liberação de peróxido de hidrogênio que pode ser medido amperometricamente pelo eletrodo:

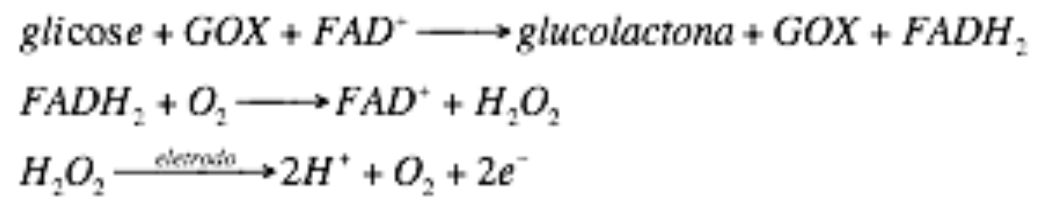

no qual $\mathrm{FAD}^{+} / \mathrm{FADH} \mathrm{H}_{2}$ são cofatores de $\mathrm{GOX}$ e $\mathrm{O}_{2}$ é o agente oxidante que pode ser encontrado no meio (Liu e Wang, 2001).

\section{A Esterase de Thermus thermophilus}

Esterases (EC 3.1.1.x) representam um diverso grupo de hidrolases que catalisam o rompimento e a formação de ligações éster. Essas enzimas estão distribuídas entre animais, plantas e microrganismos. Muitas delas apresentam um amplo espectro de ação sobre vários substratos, o que leva a crer que elas estão envolvidas no acesso a fontes de carbono ou em vias catabólicas. Além disso, as esterases apresentam uma alta regio- e estereoespecificidade, o que faz delas catalisadores atraentes para a produção de compostos enantiomericamente puros (Bornscheuer, 2002).

Uma das principais funções das esterases está na quebra de ligações éster presentes em pequenas moléculas. De acordo com essa definição, seria possível dizer que as enzimas capazes de hidrolisar, nos triacilgliceróis, as ligações éster 
entre os ácidos graxos e o glicerol, são esterases. Porém, existe uma classificação mais específica para essa classe de enzimas. A idéia mais difundida dita que as esterases (triacilglicerol hidrolases - EC 3.1.1.1) são enzimas que possuem a capacidade de hidrolisar ésteres de ácidos graxos de cadeias curtas, menores que 10 carbonos (Choi et al., 2004; Fuciños et al., 2005), ou mesmo, segundo Bornscheuer (2002), 6 carbonos. Arpigny e Jaeger (1999) vão além e adicionam a essa classificação o fato de que as esterases são capazes de hidrolisar apenas moléculas parcialmente solúveis em água. Enquanto isso, as "verdadeiras lipases" são enzimas que apresentam atividade máxima sobre triglicérides cujas cadeias de ácidos graxos sejam maiores do que 10 carbonos (Choi et al., 2004; Fuciños et al., 2005), mesmo insolúveis em meio aquoso (Arpigny e Jaeger, 1999).

As lipases também podem ser distinguidas das esterases pelo fenômeno denominado de ativação interfases, o qual é unicamente observado nas primeiras. Enquanto as esterases obedecem a cinética clássica de Michaelis-Menten, as lipases necessitam de uma mínima concentração de substrato antes que seja observada a atividade máxima (Bornscheuer, 2002). A elucidação da estrutura da enzima revelou que a ativação interfases é devida a um domínio de aminoácidos hidrofóbicos (uma espécie de tampa) que cobre os sítios ativos das lipases e que é aberta somente quando há uma concentração basal de substrato (solvente orgânico ou fase contendo triglicérides), movendo a tampa e liberando o acesso ao sítio ativo (Bornscheuer, 2002; Fuciños et al., 2005).

$\mathrm{Na}$ Tabela 1.3, estão descritas as principais diferenças entre lipases e esterases (Bornscheuer, 2002).

Tabela 1.3. Principais diferenças entre lipases e esterases.

\begin{tabular}{lll}
\hline Propriedade & Lipase & Esterase \\
\hline Substrato preferencial & Triglicérides (cadeia longa), & Ésteres simples, triglicérides \\
& alcoóis secundários & (cadeia curta) \\
Ativação de interface (tampa) & Sim & Não \\
Hidrofobicidade do substrato & Alta & Baixa \\
Enantioseletividade & Geralmente alta & Baixa ou nenhuma \\
Estabilidade em solventes & Alta & Baixa \\
\hline
\end{tabular}

Uma característica comum das lipases e esterases é que elas contêm uma tríade catalítica composta por Ser-Asp-His (em algumas lipases, Asp é substituído por Glu). Além disso, a maioria dessas enzimas possui uma seqüência consenso estrutural (Gly-Xaa-Ser-Xaa-Gly), a qual contém o resíduo de serina do sítio ativo. 
Essa seqüência está geralmente localizada entre uma folha- $\beta$ e uma $\alpha$-hélice, assumindo um loop extremamente acentuada, chamada de cotovelo nucleofílico (Choi et al., 2004).

Apesar de as esterases e lipases serem responsáveis por reações de hidrólise, elas também possuem a capacidade de catalisar outros tipos de biotransformação (e.g., esterificação e transesterificação) em ambientes contendo baixa atividade de água (Fuciños et al., 2005). Dentre potenciais aplicações, compreende-se a síntese de ésteres aromáticos para a indústria alimentícia e a resolução de misturas racêmicas para a indústria alimentícia (Verger, 1997).

Nos últimos anos, o estudo de microorganismos extremófilos cresceu consideravelmente, principalmente devido às propriedades particulares dos seus componentes celulares. Por exemplo, as enzimas termofílicas são mais termoestáveis e mais resistentes à desnaturação por proteólise ou por agentes químicos que as mesófilas (Domínguez et al., 2004; Niehaus et al., 1999). Enzimas termoestáveis são bem quistas em inúmeros processos, como as proteases na indústria de detergentes, catalases em biossensores e DNA polimerases em reações de PCR (Pantazaki et al., 2002). Além disso, essas enzimas são interessantes na investigação das necessidades estruturais que as tornam termodinamicamente estáveis (Zeikus et al., 1998). As esterases, em particular, podem ser empregadas na transesterificação de óleos vegetais, e transformando-os em biodiesel, em processo contínuo, utilizando enzimas imobilizadas. Alguns autores descreveram a existência de lipases e esterases na bactéria termófila Thermus thermophilus (Berger et al., 1995; Lagarde et al., 2002; Fuciños et al., 2005).

Haja vista todas as virtudes que uma proteína extremófila pode apresentar, não seria equivocado pensar no desenvolvimento de processos para obtenção dessas enzimas. Entretanto, existe uma limitação no que diz respeito ao processo industrial, já que altas temperaturas envolvem altos custos de operação e manutenção. Com isso, destaca-se a importância da produção dessas enzimas em organismos mesófilos (como realizado neste trabalho em leveduras do gênero Kluyveromyces), justamente pelo fato de a enzima ser produzida a altas quantidades, a um custo mais baixo em um processo menos complexo que a produção da mesma enzima no organismo homólogo. Contudo, não há trabalhos 
ainda publicados de expressão de lipases ou esterases de bactérias do gênero Thermus em qualquer hospedeiro, apesar de existirem diversos trabalhos relatando a expressão de diferentes lipases de bactérias, como por exemplo, a expressão de lipases de Bacillus subtilis NRRL B8079 em E. coli (Zock et al., 1994; Moore et al., 1996) e de esterases de Streptomyces chrysomallus em E. coli (Berger et al., 1998).

Poucos autores até o momento realizaram caracterizações de esterases de Thermus thermophilus (Fuciños et al., 2005; Domínguez et al., 2004). Fuciños et al. (2005) descreveram a existência de pelo menos duas esterases distintas em Thermus thermophilus HB27. A técnica utilizada para revelar atividade de esterase foi a descrita por Rúa et al. (1997), em que as amostras de proteínas eram submetidas a uma SDS-PAGE e depois renaturadas em Triton X-100. A atividade de esterase era revelada pela capacidade de hidrolisar o $\alpha$-naftil acetato. Neste caso, a banda de $34 \mathrm{kDa}$ apresentou atividade tanto a temperatura ambiente quanto a 65 ${ }^{\circ} \mathrm{C}$, enquanto a enzima de $62 \mathrm{kDa}$ apresentou atividade pronunciada apenas a 65 ${ }^{\circ} \mathrm{C}$. Eles também relatam a existência de um trímero de $108 \mathrm{kDa}$, o qual sugere-se que era formado pelas enzimas de menor peso molecular. Segundo os autores, essa oligomerização incrementa a proteção do monômero contra desnaturação irreversível induzida por agentes redutores. Em relação às propriedades bioquímicas das esterases de T. thermopphilus HB27, Fuciños et al., (2005) relataram dois valores ótimos de $\mathrm{pH}$, um entre 5 e 7 e outro acima de 9 . Segundo os autores, as enzimas apresentam diferentes valores de $\mathrm{pH}$ em que sua atividade é máxima. Também relatam que a temperatura em que ocorreu maior atividade enzimática de uma mistura contendo os dois peptídeos foi de $80{ }^{\circ} \mathrm{C}$, enquanto que as mesmas enzimas apresentaram perdas insignificantes de atividade quando incubadas por várias horas a $85^{\circ} \mathrm{C}$.

\section{Glicoproteínas}

Entre os diferentes tipos de modificações covalentes que as proteínas recém sintetizadas recebem nos organismos vivos, nenhuma é tão comum quanto a glicosilação (Kobata et al., 1992). É também o tipo de modificação mais diversificado, tanto pelos tipos de aminoácidos que são modificados, quanto pelas 
estruturas anexadas. Ao todo, foram identificados 13 monossacarídeos e 8 diferentes aminoácidos descritos como envolvidos em, pelo menos, 37 ligações carboidrato-proteína (Lommel et al., 2009). As cadeias de oligossacarídeos das glicoproteínas geralmente afetam diretamente parâmetros como atividade biológica, estabilidade e conformação. Entretanto, os passos que determinam a estrutura final da cadeia de açúcares são de considerável importância (Bergh et al., 1987). As origens para essa diversidade podem ser de ordem química ou biológica. Em relação à primeira, ela é resultado das diferentes maneiras em que os monossacarídeos combinam entre si, de forma que são formadas diferentes cadeias com distintos comprimentos, posição das ligações e pontos de ramificação. Dessa forma, uma imensa variedade de diferentes estruturas podem ser construídas com uma pequena variedade de monossacarídeos (Lis et al., 1993). Além disso, a acessibilidade do sítio de glicosilação, ou mesmo do endereçamento final da proteína, se intracelular ou extracelular, podem resultar em proteínas diferentemente glicosiladas (Bergh et al., 1987). A diversidade biológica deriva do fato de que, enquanto proteínas são produtos primários do código genético, os açúcares são secundários. Como resultado, as glicosilações são específicas a cada espécie e tipo de célula. Além disso, são determinadas pela estrutura primária da proteína e pelos sítios de ligação dos carboidratos (Lis et al., 1993) e também pelo tempo de passagem da proteína pelo retículo endoplasmático e pelo complexo de Golgi pode gerar diferenças nos níveis de glicosilação das proteínas e isso está intrinsecamente ligado à célula hospedeira (Hsieh et al., 1983).

Mais da metade das proteínas estudadas são glicosiladas (Apweiler et al., 1999). Elas possuem um ou mais sítios potenciais para a glicosilação $N$ ou O, os quais podem ser ou não glicosilados. No caso da $\mathrm{N}$-glicosilação, a condição básica necessária para que seja ligada covalentemente uma cadeia de carboidratos na proteína é que exista na estrutura primária desta uma das seqüências de aminoácidos consenso: Asn-Xaa-Ser ou Asn-Xaa-Thr (Xaa pode ser qualquer aminoácido com exceção da prolina) (Roitsch et al., 1989). A estrutura de carboidratos é ligada à proteína via o grupamento amida presente na asparagina da seqüência consenso (Benz e Schimidt, 2002). O passo inicial da via de inserção de glicosilação é a ligação do oligossacarídeo $\mathrm{Glc}_{3} \mathrm{Man}_{9} \mathrm{GlcNAc}_{2}$ no lipídeo carregador 
dolicol fosfato. Após isto, a estrutura de carboidratos é transferida ao peptídeo em questão e, no retículo endoplasmático, parte da cadeia de açúcares é processada, com a retirada de três resíduos de glicose e um de manose, resultando em um núcleo com a seguinte estrutura: $\operatorname{Man}_{8} \mathrm{GlcNAc}_{2}$. Outros processamentos ocorrem no complexo de Golgi e são diferentes quando comparados os mecanismos existentes em células animais e leveduras (Figura 1.2). Em mamíferos, ocorre retirada de mais manoses e uma adição seletiva de um diferente número de monossacarídeos (GlcNAc, galactose, fucose, ácido siálico). Já em $S$. cerevisiae, o processamento envolve predominantemente a adição de somente resíduos de manose a fim de criar o chamado núcleo interno, cuja estrutura é Man ${ }_{9-15} \mathrm{GlcNAc}_{2}$. Em alguns casos de glicoproteínas que são secretadas, o núcleo interno é outra vez processado com a adição de uma cadeia externa composta basicamente por um esqueleto principal de manoses unidas por ligação $\alpha-1,6$ e ramificações também compostas por manoses ligadas $\alpha-1,2$ ou $\alpha-1,3$ (Lehle et al., 1995). As cadeias externas podem variar de 50 a 150 resíduos de manose em leveduras, isso contribui para a heterogeneidade da maioria das glicoproteínas secretadas por esses organismos, e também aumenta o caráter imunogênico das moléculas (Flores-Carreón et al., 1990). Em relação às funções biológicas das glicosilações (listadas na Tabela 1.4), Lis et al. (1993) oportunamente sugerem que estejam relacionadas em ajudar o poli-peptídeo nascente a alcançar sua correta conformação e auxiliar na estabilização da proteína madura. Como conseqüência, isso pode afetar todas as funções dependentes da conformação da proteína, como notaram Sagt et al. (2000) que, após a inserção de um sítio de glicosilação na enzima cutinase, observaram aumento na secreção da mesma para o meio extracelular, fato esse que deve estar relacionado com a conformação da proteína recombinante. O efeito sobre a correta conformação da proteína dependerá de cada caso, pois está relacionada à extensão da cadeia glicosídica e de sua posição na cadeia polipeptídica (Lis et al., 1993). 


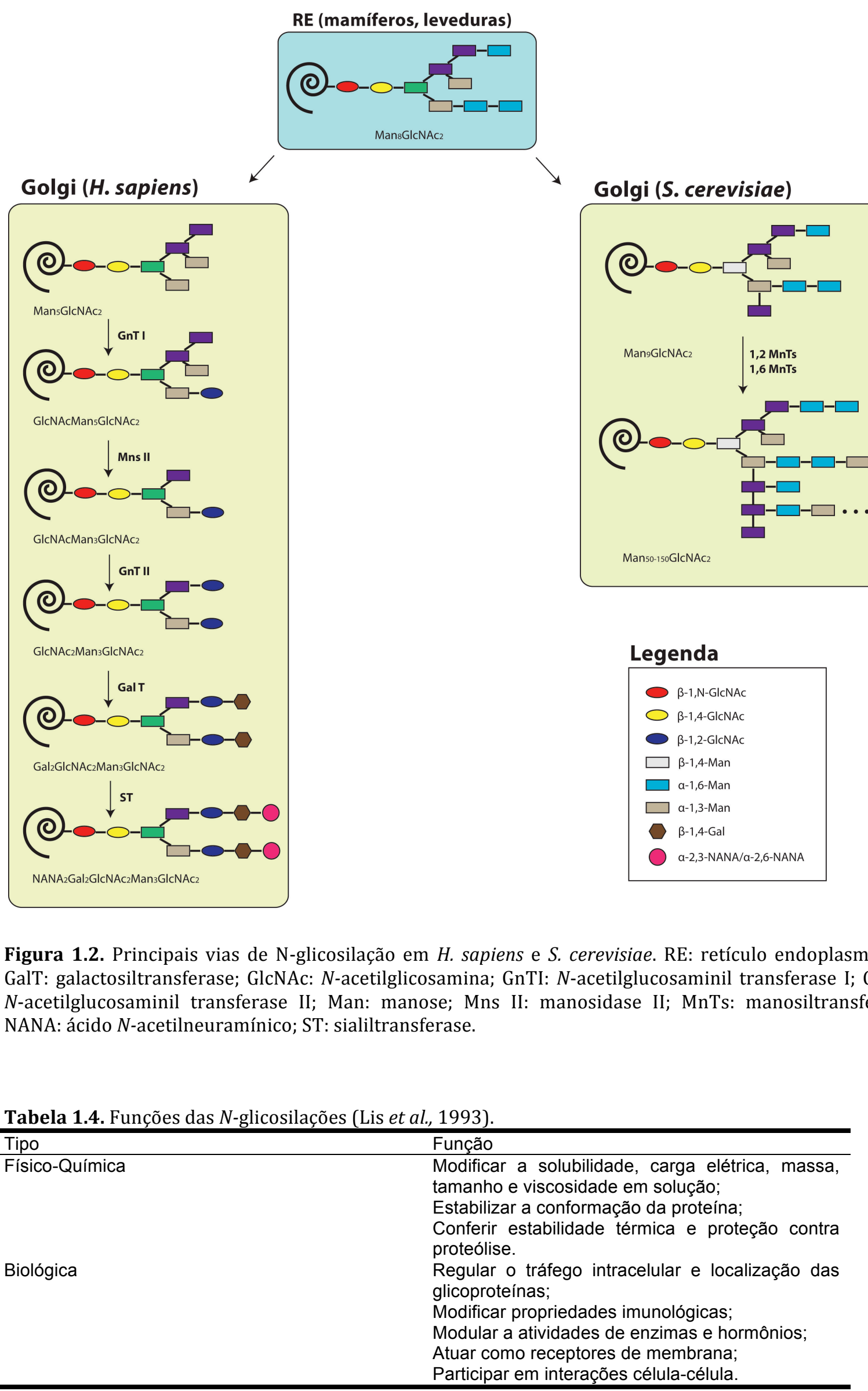


Já as O-glicosilações ligadas a resíduos de Ser e Thr foram primeiramente identificas em S. cerevisiae (Sentandreu e Northcote, 1968). Todos os hidroxiaminoácidos (Ser, Thr, Tyr) podem estar envolvidos em O-glicosilações, apesar de que os mais comuns sejam Ser e Thr (Spiro, 2002). Os resíduos de açúcares são ligados pelos grupamentos hidroxila aos resíduos de aminoácidos citados via ligação O-glicosídica (Lommel et al., 2009). Cadeias de açúcares O-ligadas, as quais não são ramificadas e contém no máximo quatro ou cinco resíduos de açúcares, são mais curtas quando comparadas com os componentes de $N$-glicosilações (StrahlBolsinger et al., 1999). Em todas as leveduras e fungos estudados até o momento, o terminal redutor do resíduo de manose nos $O$-glicanos é unido por ligação $\alpha$ com a Ser ou Thr e é estendido até formar uma manotriose ligada por ligações $\alpha-1,2$

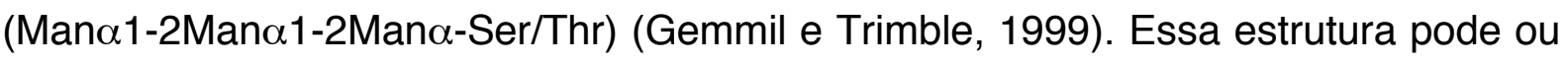
não ser alongada de acordo com a espécie do fungo/levedura (Lommel et al., 2009). A O-glicosilação em Saccharomyces cerevisiae é crucial para a estabilidade, localização e/ou função das proteínas da membrana plasmática e afeta vários processos celulares como a manutenção da polaridade celular (Lommel et al., 2004). Essa polaridade está relacionada à morfologia do brotamento. Por exemplo, células mutantes em relação às $O$-glicosilações exibem brotamento unipolar em vez do padrão comum: o axial. Uma outra função seria a solubilização de proteínas erroneamente processadas no retículo endoplasmático (Nakatsukasa et al., 2004).

Apesar de que a glicosilação é um mecanismo comumente relacionado à células eucarióticas, essa modificação pós-traducional também ocorre em bactérias (Benz e Schimidt, 2002; Wacker et al., 2002)., apesar de as mesmas não apresentarem a estrutura do retículo endoplasmático, local no qual as proteínas sofrem esse processamento em Eukarya. Nos procariotos (Archaea e Bacteria), os primeiros exemplos de glicosilação em proteínas foram verificados em Archaea, apresentando glicosilações nas proteínas de superfície (Mescher et al., 1974). Assim como nos organismos superiores, a seqüência consenso para a $N$-glicosilação em procariotos também é a Ser/Thr-Xaa-Asn (Moens e Vanderleyden, 1997) e as cadeias de açúcares podem ser separadas da estrutura protéica por tratamento por endoglicosidases, como a EndoH. Uma seqüência consenso além de um resíduo de 
Ser/Thr não foi identificada para a formação de O-glicosilações (Benz e Schimidt, 2002).

Saccharomyces cerevisiae é uma espécie conhecida por alongar demasiadamente a cadeia externa das $\mathrm{N}$-glicosilações, fazendo com que as proteínas tornem-se hiperglicosiladas, com um conteúdo de carboidratos muito imunogênico (Lehle et al., 1995; Merico et al., 2004). Mutantes incapazes de sintetizar a cadeia externa de manoses sobrevivem, porém, apresentam crescimento reduzido e sofrem distorção da parede celular (Ballou et al., 1980; Lehle et al., 1995). S. cerevisiae, assim como as outras leveduras, não edita o oligossacarídeo original $\mathrm{Glc}_{3} \mathrm{Man}_{9} \mathrm{GlcNAc}_{2}$ adicionado às proteínas recém-sintetizadas. Ao contrário, a levedura alonga diretamente a estrutura com resíduos de manose. O passo inicial para a elongação da cadeia é a adição de uma manose $\alpha 1,2$ ligada à última manose no núcleo principal (Gemmil e Trimble, 1999). O alongamento da cadeia depende do sítio em que está ocorrendo a glicosilação (Jars et al., 1995). Alguns sítios de certas glicoproteínas são preferencialmente alongados, enquanto outros tendem a manter somente o núcleo. Isso se deve a fatores estéricos, como o acoplamento preferencial de glicosil-transferases por determinadas estruturas terciárias da proteína-substrato (Trimble et al., 1983), fenômeno o qual ocorre também em eucariotos superiores (Hsieh et al., 1983). O fenômeno da hipermanosilação das proteínas é comum também em $K$. lactis, porém esta espécie apresenta este fenômeno com menor intensidade que $S$. cerevisiae. Uma virtude de $K$. lactis em relação ao sistema de glicosilação está no fato que, além de adicionar resíduos de manose e galatactose, como ocorre geralmente nas leveduras, esta levedura é capaz de adicionar GlcNAc, uma modificação comum em células animais (Raschke e Ballou, 1972), fato incomum em outros gêneros de leveduras.

O fato de as células de leveduras não realizarem exatamente o mesmo padrão de glicosilações que as células animais tem levado atualmente um grande número de cientistas ao desenvolvimento de sistemas ditos "humanizados", os quais correspondem a leveduras (ou outros organismos) capazes de glicosilar proteínas heterólogas com o mesmo padrão realizado por células animais. A principal aplicação dessa técnica está no desenvolvimento da produção de moléculas pouco imunogênicas, de uso farmacêutico. O principal trunfo desses organismos 
produtores de proteínas humanizadas, seria aliar a produtividade de sistemas unicelulares à exatidão das moléculas sintetizadas em células animais.

Células de mamíferos e de leveduras possuem a mesma via biossintética inicial para a síntese de $N$-glicanos. Como mostrado anteriormente, ambos organismos partem de um núcleo comum: $\mathrm{Man}_{8} \mathrm{GlcNAc}_{2}$, quando a estrutura parte para o complexo de Golgi. A partir deste ponto, as células animais retiram três resíduos de manose e adicionam um de $\mathrm{N}$-acetilglicosamina. Subseqüentemente, ocorrem as demais edições que resultam em proteínas "sializadas", as quais possuem um resíduo de ácido siálico na extremidade da cadeia de carboidratos. Esse sistema de transferência é inexistente em leveduras. Em contrapartida, as leveduras estendem a cadeias principalmente com resíduos de manose (Lehle et al., 1995; Hamilton e Gerngross, 2007; Lommel et al., 2009), conforme já mencionado acima.

Hamilton e Gerngross (2007) desenvolveram uma linhagem mutante de Pichia pastoris capaz de mimetizar uma cadeia glicosídica idêntica à sintetizada por mamíferos. Através de deleções de genes responsáveis pela extensão do núcleo de açúcares e pela expressão de glicosiltransferases específicas de mamíferos, os autores alcançaram o padrão de glicosilação realizado em mamíferos. O passo final foi a adição de ácido siálico, o qual foi resolvido pela expressão de seis genes responsáveis pela cadeia de síntese e transferência deste composto desde o precursor UDP-GIcNAc. O resultado foi uma levedura capaz de sintetizar glicoproteínas com o mesmo padrão de glicosilação presente em humanos, o qual está apresentado na Figura 1.2.

Os avanços da "humanização" das vias secretórias de proteínas ocorrido em leveduras como Pichia pastoris devem-se ao grande número de pesquisadores envolvidos no estudo destas espécies e ao vasto conhecimento gerado sobre elas. Em leveduras como K. marxianus (estudada no presente trabalho), que foram objeto de poucos estudos de expressão de proteínas heterólogas, ainda não há registros de tentativas de "humanização" de vias secretórias. 
Capítulo 2

\section{Diversidade fisiológica na espécie Kluyveromyces marxianus}

Artigo submetido 


\section{DIVERSIDADE FISIOLÓGICA NA ESPÉCIE Kluyveromyces} marxianus

Saul Nitsche Rocha ${ }^{1}$, José Abrahão-Neto ${ }^{2}$ e Andreas Karoly Gombert ${ }^{1 \S}$

${ }^{1}$ Departamento de Engenharia Química, Universidade de São Paulo, CP 61548, 05424-970, São Paulo-SP, Brasil

2 Faculdade de Ciências Farmacêuticas, Universidade de São Paulo, Av. Prof. Lineu Prestes, 580, bloco 15, 05508-900, São Paulo-SP, Brasil

$\S$ Autor para correspondência

E-mail: andreas.gombert@poli.usp.br

FAX: +551130912284

\section{Resumo}

Três diferentes linhagens da levedura Kluyveromyces marxianus, denominadas CBS 6556, CBS 397 e CBS 712, foram cultivadas em meio mineral suplementado com vitaminas e uma única fonte de carbono, com o intuito de se avaliar variações fisiológicas intra-específicas nesta levedura (Kluyveromyces lactis CBS 2359 foi utilizada como referência no presente estudo). Além disto, o trabalho teve como objetivo selecionar a linhagem mais apropriada para a futura expressão de proteínas heterólogas. Os critérios fisiológicos envolvidos neste estudo/seleção foram: formação de metabólitos extracelulares, velocidade específica de crescimento, rendimento de substrato em biomassa e capacidade de secreção de proteínas (inferida pela medição da atividade extracelular da inulinase, uma enzima homóloga e glicosilada). Cada linhagem foi cultivada em diferentes temperaturas (30 ${ }^{\circ} \mathrm{C}$ ou $37^{\circ} \mathrm{C}$ ) e em diferentes fontes de carbono (glicose, lactose ou sacarose). $\mathrm{K}$. marxianus CBS 6556 foi a linhagem de mais rápido crescimento, com velocidade específica máxima de $0,70 \pm 0,05 \mathrm{~h}^{-1}$, a $37^{\circ} \mathrm{C}$, em cultivos utilizando sacarose como fonte de carbono. Essa linhagem também apresentou mais alta atividade de inulinase extracelular $(1,65 \pm 0,20 \mathrm{U} / \mathrm{mg} \mathrm{MS})$. A menor formação de metabólitos e, conseqüentemente, o maior rendimento de substrato em biomassa foi alcançado por K. marxianus CBS 712 , com valor máximo de $0,59 \mathrm{~g} \mathrm{MS} / \mathrm{g}$ SUC a $37{ }^{\circ} \mathrm{C}$. Nesta 
condição, os metabólitos extracelulares foram formados a uma relação de 16 C$\mathrm{mmol} / \mathrm{C}-\mathrm{mol}$ de fonte de carbono consumida.

\section{Introdução}

Em contraste a K. lactis, espécie que possui a linhagem CBS 2359 como referência para pesquisa na comunidade científica, o trabalho sobre $K$. marxianus não vem sendo feito sistematicamente, o que significa que muitas linhagens diferentes já foram investigadas. Se, por um lado, isso pode resultar em uma vasta diversidade metabólica e várias potenciais aplicações biotecnológicas para essa levedura, por outro lado, isso acarreta em dificuldade na interpretação de todos os dados experimentais disponíveis para esse organismo. Isso é principalmente causado pelos seguintes fatos, entre outros: investigação desenvolvida em diferentes laboratórios, com objetivos diferentes, e diferentes linhagens (o isolamento da mesma é freqüentemente parte do estudo). Além disso, existe um grau substancial de polimorfismo genético entre as espécies, o que foi evidenciado no trabalho de Belloch et al. (2002). Esse polimorfismo pode refletir no metabolismo/fisiologia, uma questão que não foi investigada por muitos autores sistematicamente (Mahmoud e Kisikowski, 1982). Nesse contexto, o objetivo deste trabalho foi o de investigar o polimorfismo em espécies de $K$. marxianus em nível fisiológico. Para isso, foram selecionadas três das linhagens mais populares: CBS 6556, CBS 397 (=ATCC 46537, NRRL y2415), e CBS 712 (=NRRL y8281, PYCC 3886). K. lactis CBS 2359 foi estudada em paralelo como referência. Os parâmetros fisiológicos avaliados foram: velocidade específica de crescimento, rendimento de substrato em biomassa, formação de metabólitos e atividade de inulinase extracelular. 


\section{Materiais e métodos}

\subsection{Reagentes, linhagens, preservação e inóculo}

Todos os reagentes utilizados eram de grau analítico. A água utilizada nos experimentos foi filtrada por um sistema de filtração Milli-Q (Millipore, Billerica, EUA).

K. lactis CBS 2359 e K. marxianus CBS 712 foram gentilmente cedidas pela Profa. Lucília Domingues da Universidade do Minho, Braga, Portugal. O Prof. Marcos Morais Jr., da Universidade Federal de Pernambuco (Recife, Brasil) forneceu a linhagem K. marxianus CBS 6556. Já a linhagem K. marxianus CBS 397 foi obtida a partir do banco NRRL (Peoria, USA), através do curador Dr. Cletus Kurtzman. Cada linhagem foi submetida a um cultivo overnight a $30{ }^{\circ} \mathrm{C}$ em um frasco Erlenmeyer chicanado de volume $500 \mathrm{~mL}$ contendo $100 \mathrm{~mL}$ de meio YPD (extrato de levedura, $10 \mathrm{~g} / \mathrm{L}$; peptona, $20 \mathrm{~g} / \mathrm{L}$; glicose, $20 \mathrm{~g} / \mathrm{L})$. Após o cultivo, foi adicionado glicerol a uma concentração final de $15 \% \mathrm{v} / \mathrm{v}$ e alíquotas de $2 \mathrm{~mL}$ foram armazenadas a $-80^{\circ} \mathrm{C}$ em tubos criogênicos estéreis (Kiers et al., 1998). Os inóculos foram preparados primeiro transferindo-se algumas células congeladas dos tubos de estoque congelados para uma placa contendo meio YPD, utilizando-se uma alça de platina. Após $36 \mathrm{~h}$ de incubação a $30^{\circ} \mathrm{C}$, colônias isoladas cresciam na placa. Uma colônia foi utilizada para inocular um frasco Erlenmeyer de $500 \mathrm{~mL}$ contendo $100 \mathrm{~mL}$ de meio mineral contendo a mesma fonte de carbono que seria utilizada no cultivo. Além disso, os frascos de inóculo foram sempre incubados na mesma temperatura do cultivo $\left(30^{\circ} \mathrm{C}\right)$, a $300 \mathrm{rpm}$ em um incubador rotativo New Brunswick (Edison, EUA).

\subsection{Meio mineral utilizado nos cultivos}

O meio mineral (Verduyn et al., 1992) foi preparado como descrito a seguir. A solução nutriente era composta por: $\left(\mathrm{NH}_{4}\right)_{2} \mathrm{SO}_{4}, 10 \mathrm{~g} / \mathrm{L} ; \mathrm{KH}_{2} \mathrm{PO}_{4}, 6 \mathrm{~g} / \mathrm{L}$; 
$\mathrm{MgSO}_{4} \cdot 7 \mathrm{H}_{2} \mathrm{O}, 1 \mathrm{~g} / \mathrm{L}$. Ftalato ácido de potássio foi adicionado a essa solução a uma concentração final de $0,2 \mathrm{M} \mathrm{e} \mathrm{o} \mathrm{pH} \mathrm{foi} \mathrm{ajustado} \mathrm{para} \mathrm{5,0} \mathrm{com} \mathrm{a} \mathrm{adição} \mathrm{de} \mathrm{KOH}$ puro. Uma solução contendo a fonte de carbono a ser estudada (glicose, lactose ou sacarose) foi preparada em água pura a uma concentração de $20 \mathrm{~g} / \mathrm{L}$. As duas soluções foram esterilizadas separadamente $\left(121^{\circ} \mathrm{C}, 20 \mathrm{~min}\right.$.) e ambas foram resfriadas a temperatura ambiente. $50 \mathrm{~mL}$ da solução de nutrientes foram adicionados a $50 \mathrm{~mL}$ da solução de fonte de carbono. A essa mistura, foram adicionados $100 \mu \mathrm{L}$ de uma solução de microelementos pré-esterilizada $\left(121^{\circ} \mathrm{C}, 20\right.$ min.) e mais $100 \mu \mathrm{L}$ de uma solução de vitaminas esterilizada por filtração $(0,22 \mu \mathrm{m})$, completando assim a composição do meio. A composição da solução de elementos traço foi, por litro: EDTA, $15 \mathrm{~g} ; \mathrm{ZnSO}_{4} .7 \mathrm{H}_{2} \mathrm{O}, 4,5 \mathrm{~g} ; \mathrm{CoCl}_{2} \cdot 6 \mathrm{H}_{2} \mathrm{O}, 1 \mathrm{~g} ; \mathrm{MnCl}_{2} .4 \mathrm{H}_{2} \mathrm{O}, 1$ g; $\mathrm{CuSO}_{4} \cdot 5 \mathrm{H}_{2} \mathrm{O}, 0,3 \mathrm{~g} ; \mathrm{CaCl}_{2} \cdot 2 \mathrm{H}_{2} \mathrm{O}, 4,5 \mathrm{~g} ; \mathrm{FeSO}_{4} .7 \mathrm{H}_{2} \mathrm{O}, 3 \mathrm{~g} ; \mathrm{NaMoO}_{4} \cdot 2 \mathrm{H}_{2} \mathrm{O}, 0,4 \mathrm{~g}$; $\mathrm{H}_{3} \mathrm{BO}_{3}, 1 \mathrm{~g} ; \mathrm{KI}, 0,1 \mathrm{~g}$. Já a composição da solução de vitaminas foi a seguinte (por litro de solução): biotina, $0,05 \mathrm{~g}$; pantotenato de cálcio, $1 \mathrm{~g}$; ácido nicotínico, $1 \mathrm{~g}$; inositol, $25 \mathrm{~g}$; tiamina-HCl, $1 \mathrm{~g}$; piridoxina- $\mathrm{HCl}, 1 \mathrm{~g}$; e ácido para-aminobenzóico, 0,2 g. Ambas as soluções-estoque (de micronutrientes e de vitaminas) foram mantidas a $4{ }^{\circ} \mathrm{C}$.

\subsection{Cultivos em batelada em frascos Erlenmeyer}

Os cultivos em batelada foram iniciados pela adição de uma certa quantidade de células do inóculo, as quais estavam na fase exponencial de crescimento, de forma que a densidade óptica a $600 \mathrm{~nm}$ do início do cultivo fosse 0,1 . Antes de ocorrer a transferência de células para o frasco de cultivo, a suspensão proveniente do inóculo foi centrifugada (9030 x g, $1 \mathrm{~min}$ ), lavada com meio de cultura fresco, centrifugada novamente $(9030 \times \mathrm{g}, 1 \mathrm{~min})$, as células precipitadas foram ressuspendidas em meio de cultura fresco e então transferidas para o frasco Erlenmeyer chicanado de $500 \mathrm{~mL}$ contendo $100 \mathrm{~mL}$ do meio de cultivo. Esses frascos chicanados (as chicanas auxiliam na transferência de oxigênio para o meio líquido), bem como o sistema de retirada de amostra durante o cultivo, estão ilustrados na Figura 2.1. Todo o processo de preparação do inóculo e início do cultivo está ilustrado na Figura 2.2. As quatro linhagens foram cultivadas em meio 
mineral suplementado com glicose, lactose ou sacarose, a $30^{\circ} \mathrm{C}$ ou $37^{\circ} \mathrm{C}$. O pH dos cultivos era mantido a 5.0 pelo tamponamento do meio com ftalato- $\mathrm{KOH} \mathrm{0,1} \mathrm{M}$. Ao final dos cultivos, o pH do meio ficou sempre entre 4,5 e 5,0. Esse tampão se mostrou eficaz a concentrações de 100 a 200 mM, contendo a diminuição do pH do cultivo até no máximo 4,5. A $50 \mathrm{mM}$, o tampão não é capaz de manter o pH do cultivo, enquanto a uma concentração de 400 mM, não há crescimento. Os cultivos foram realizados em duplicata e em ordem aleatória.

A retirada de amostras ocorreu a cada hora. No caso de K. lactis CBS 6556, a amostragem era realizada a cada 30 minutos durante a fase exponencial. As amostras eram utilizadas para determinação de densidade óptica a $600 \mathrm{~nm}$, da concentração dos metabólitos e de fonte de carbono por HPLC, além da atividade de inulinase (nos cultivos em que a sacarose foi utilizada como fonte de carbono). As amostras utilizadas na análise de HPLC foram filtradas utilizando um filtro 0,22 $\mu \mathrm{m}$ (Millex - Millipore, Billerica, EUA) e congeladas a $-20^{\circ} \mathrm{C}$.

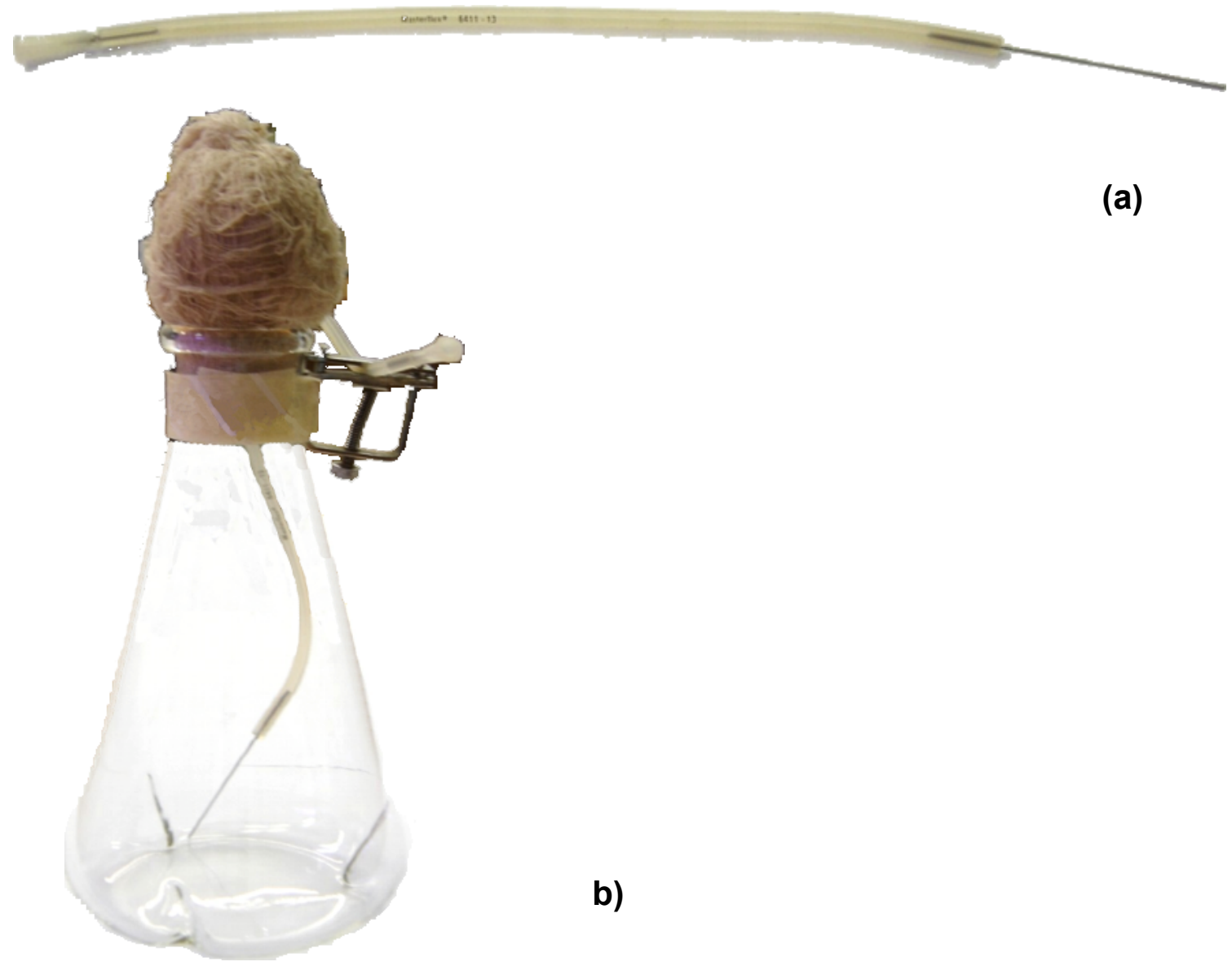

Figura 2.1. (a) Detalhe do amostrador utilizado nos ensaios em frascos Erlenmeyer. (b) Vizualização do sistema completo de ensaio. 

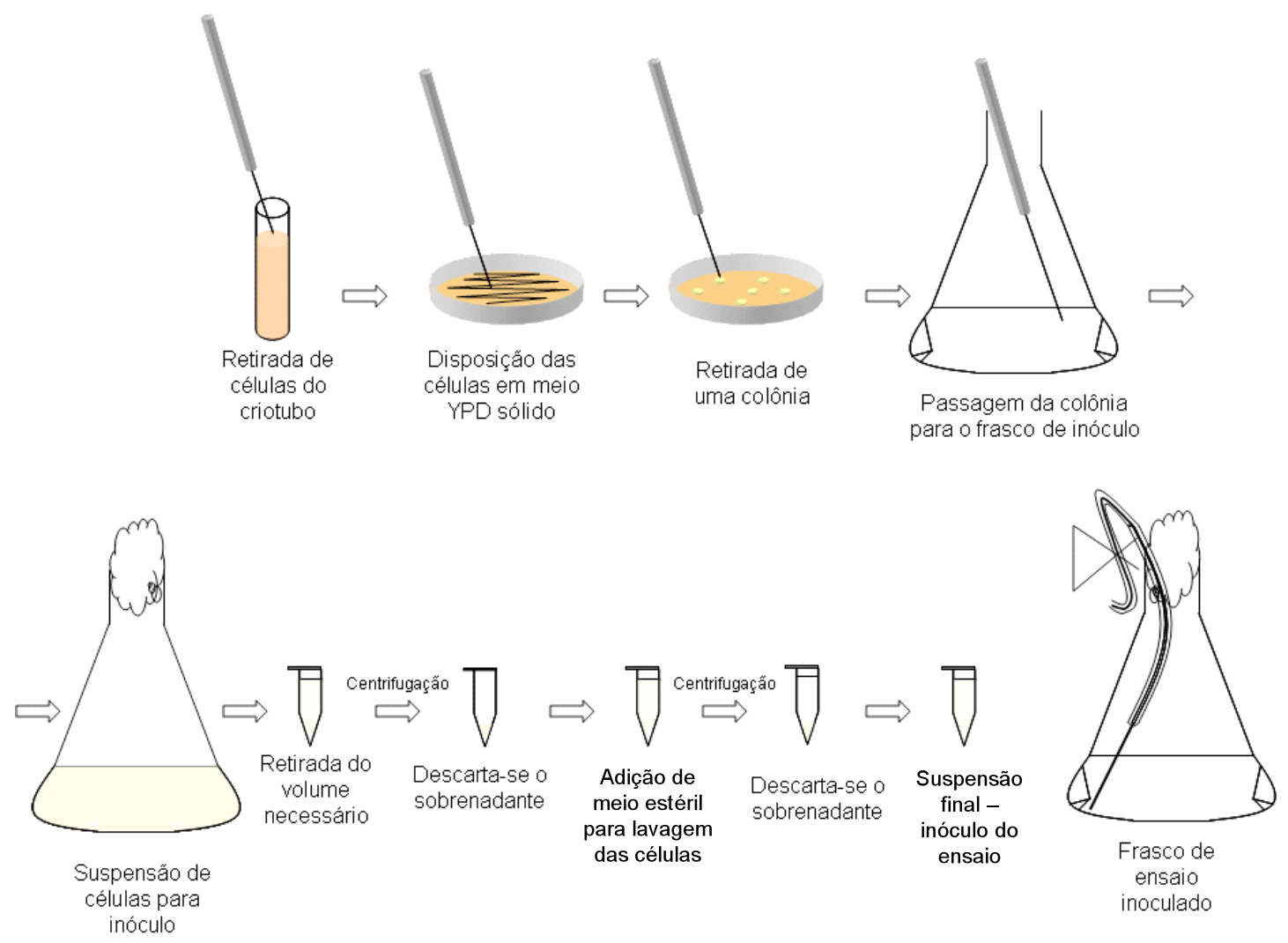

Figura 2.2. Representação do procedimento de inoculação dos ensaios.

3.4. Determinação de glicose, lactose, sacarose, metabólitos extracelulares e concentração de biomassa

A determinação de glicose, lactose, etanol, ácido acético, ácido succínico, ácido pirúvico e glicerol foi realizada em HPLC (Waters, Milford, EUA) utilizando a coluna analítica BioRad (Hercules, EUA) Aminex HPX-87H. A fase móvel era $\mathrm{H}_{2} \mathrm{SO}_{4}$ $5 \mathrm{mM}$, utilizada numa vazão de 0,6 $\mathrm{mL} / \mathrm{min}$. A detecção foi feita por índice de refração no detector Waters 410 (sensibilidade 32; scaling-factor 20). A integração dos picos e cálculo das concentrações foi realizada em software do próprio fabricante do equipamento Waters Millenium 32. Curvas padrão foram feitas a partir da altura dos picos a cada vez que o equipamento era religado. A sacarose foi determinada pela medição da concentração de glicose após hidrólise total, utilizando-se o kit para determinação de Sacarose/D-Glicose/D-Frutose da Boehringer-Mannheim (Ingelheim, Alemanha, Cat no. 10716260 035). 
A análise da concentração celular em cada tempo de cultivo foi feita medindose a densidade óptica da suspensão e relacionando-a com a concentração celular. Depois de retirada a amostra, $2 \mathrm{~mL}$ eram usados para a leitura em espectrofotômetro Beckman Du-530 com um comprimento de onda de $600 \mathrm{~nm}$. Para que não houvesse distorções na medida devido à não linearidade entre absorbância e concentração celular, eram aceitas leituras de absorbância de até 0,4. Caso contrário, a amostra sofria diluições de 10 ou 50 vezes, dependendo do caso. No final de cada ensaio, a concentração celular foi determinada a partir da massa seca de células formadas a fim de correlacioná-la à densidade ótica. Um determinado volume se suspensão de células foi filtrado em uma membrana de 0,45 $\mu \mathrm{m}$. $\mathrm{O}$ volume utilizado para a filtração variou entre 5,10 e $25 \mathrm{~mL}$ dependendo da concentração, de forma que se obtivesse sempre valor igual ou menor a $30 \mathrm{mg}$ de células secas na membrana. Depois de filtrada a suspensão, a membrana foi seca em forno de microondas (180 W) por 15 minutos. Após a secagem, foi colocada em um dessecador por 10 minutos para estabilizar a temperatura. A massa de células foi determinada em balança analítica (Mettler-Toledo AB204) e a concentração (em $\mathrm{g} / \mathrm{L}$ ) calculada de acordo com o volume filtrado. Com a relação entre massa seca e densidade ótica, era possível fazer os cálculos de $\mathrm{Y}_{\mathrm{X} / \mathrm{S}}{ }^{\mathrm{EXP}}$, descritos posteriormente.

\subsection{Tratamento dos dados}

Nos cultivos, os dados de densidade óptica foram convertidos a concentração celular usando uma relação calculada no final de cada experimento. Em duplicata, era medida a massa seca de uma suspensão de células de densidade óptica conhecida. A relação era utilizada para a inferência da concentração celular nos outros pontos do ensaio. A concentração celular em gMS/L (gramas de massa seca por litro) foi usada para o cálculo do coeficiente de rendimento de substrato a células $\left(\mathrm{Y}_{\mathrm{X} / \mathrm{S}}\right)$.

Este coeficiente foi apresentado de duas maneiras. O fator de conversão de substrato a células global $\left(\mathrm{Y}_{\mathrm{X} / \mathrm{S}}{ }^{\mathrm{GLO}}\right)$ é a relação entre a massa de células formada e a massa de substrato consumido no final do cultivo, ou seja, quando estava esgotada 
a fonte de carbono (Eq. 3.1). Dessa forma, observa-se quanto da fonte de carbono foi convertida em células. Em contrapartida, o coeficiente de rendimento de substrato a células durante a fase exponencial $\left(\mathrm{Y}_{\mathrm{X} / \mathrm{S}}{ }^{\mathrm{EXP}}\right)$ é calculado a partir de uma regressão linear de pontos de concentração de biomassa em função da concentração de substrato, durante o período correspondente à fase exponencial. Assim, o coeficiente angular da reta ajustada é o $Y_{X / S}{ }^{\text {EXP. }}$. No caso dos cultivos em que sacarose foi utilizada como fonte de carbono, o $Y_{X / S}{ }^{E X P}$ não foi calculado, pois parte da sacarose ainda é hidrolisada em glicose e frutose no meio extracelular.. Assim, a velocidade de desaparecimento da sacarose não é apenas proporcional ao seu consumo, mas também à sua hidrólise, o que impossibilita o cálculo do coeficiente de rendimento na fase exponencial.

$Y_{X / S}$ global $=\frac{X_{\text {final }}}{S_{\text {inicial }}}$

A velocidade específica de crescimento $\left(\mu\left[h^{-1}\right]\right)$ é definida conforme a equação 3.2

$\mu=\frac{1}{X} \frac{d X}{d t}$

No qual $X$ : concentração celular (g/L)

$t$ tempo (h)

$\mu$ : velocidade específica de crescimento $\left(\mathrm{h}^{-1}\right)$

Integra-se a equação 3.2 com as condições de contorno: $t=0, X=X_{0}$ e $t=t$, $X=X:$

$\int_{0}^{t} \mu d t=\int_{X_{0}}^{X} \frac{d X}{X}$

E se assume $\mu$ constante durante a fase exponencial. Isso resulta na equação a seguir:

$$
\mu t=\ln \left(\frac{X}{X_{0}}\right)
$$


Ou seja, $\mu$ será o coeficiente angular de $\ln X$ em função do tempo. Entretanto, a fase exponencial é aquela em que a velocidade específica de crescimento apresenta o seu valor máximo. Portanto, a linearização mostrada é aplicada sobre os pontos da fase exponencial. Desta forma, o coeficiente angular da reta dará o valor de $\mu$ quando este for máximo, ou seja $\mu_{\text {máx }}\left(h^{-1}\right)$.

Analogamente temos $\mu_{\mathrm{S}}$ (velocidade específica de consumo de substrato máxima), que informa a velocidade com que o substrato está sendo consumido por quantidade de células. Seu cálculo e feito pela seguinte equação:

$$
\mu_{S}=\frac{1}{S} \frac{d S}{d t}
$$

$\mathrm{Na}$ prática, supõe-se que o $\mu_{\mathrm{s}}$ é máximo durante a fase exponencial de crescimento, e o cálculo de $\mu_{\mathrm{S}}{ }^{\mathrm{EXP}}$ é feito como mostrado na equação 3.6.:

$\mu_{S}^{E X P}-\frac{\mu_{\operatorname{ms}}}{Y_{X / S}^{E X P}}$

\subsection{Determinação da atividade de inulinase extracelular}

A atividade de inulinase extracelular (EC 3.2.1.7) foi medida utilizando-se o sobrenadante da cultura, obtido pela filtração da suspensão celular em filtro de porosidade 0,22 $\mu \mathrm{m}$. Adiciona-se $0,2 \mathrm{~mL}$ deste sobrenadante a 0,8 $\mathrm{mL}$ de uma solução $2 \%$ de inulina em tampão acetato, $\mathrm{pH} 4,5$. Procede-se a reação por 10 minutos a $50{ }^{\circ} \mathrm{C}$ (GrootWassink e Hewitt, 1983; Rouwenhorst, 1988). A inativação da enzima é feita mergulhando o tubo em água a $100{ }^{\circ} \mathrm{C}$ por 10 minutos (Pessoa Jr. et al., 1996). Uma unidade de atividade da enzima é a quantidade de enzima necessária para formar $1 \mu \mathrm{mol}$ de frutose por minuto. A frutose formada é medida por um kit enzimático combinado (Boehringer-Mannheim Cat no. 10716260035). Os

níveis basais de frutose de cada amostra eram medidos de forma a serem descontados da frutose formada pela ação da inulinase. 


\section{Resultados e Discussão}

\subsection{Velocidade específica de crescimento}

Recentemente, Groeneveld et al. (2009) discutiram a importância da velocidade de crescimento em organismos conhecidos como "fábricas vivas". De acordo com os autores, o organismo eucarioto de mais rápido crescimento conhecido é a levedura Kluyveromyces marxianus. Por exemplo, altas velocidades de crescimento são interessantes na produção de proteína unicelular e $K$. marxianus é considerada como uma boa alternativa para tal (Bergkamp et al.,1993; Hensing et al., 1995). Levando isso em consideração, um estudo relativo à variação intraespecífica da máxima velocidade de crescimento torna-se uma importante proposta e nos permite saber a mais rápida linhagem do organismo eucarioto de crescimento mais rápido.

A máxima velocidade específica de crescimento refere-se à biossíntese de material celular em situação de excesso de todos os nutrientes (i.e. condições de saturação de substrato, relativamente a suas proteínas transportadores), e é somente limitada pelas propriedades biológicas próprias da célula (Groeneveld et al., 2009). No caso deste trabalho, a máxima velocidade de crescimento foi calculada para as células crescendo em meio mineral, suplementado com vitaminas e uma única fonte de carbono, no qual as velocidades de crescimento podem ser inferiores às observadas em meio complexo, uma vez que as células têm que sintetizar, a partir da única fonte de carbono, todas as moléculas precursoras para a biossíntese de componentes celulares, o que não ocorre no caso do meio complexo.

De acordo com a Tabela 2.1, K. marxianus CBS 6556 apresentou, em geral, maior velocidade específica que as outras linhagens estudadas, inclusive $K$. lactis CBS 2359. Valores mais altos de $\mu_{\text {máx }}$ foram observados quando as células foram cultivadas em sacarose, a $37{ }^{\circ} \mathrm{C}\left(0,70 \pm 0.05 \mathrm{~h}^{-1}\right)$. Os dados obtidos neste trabalho estão de acordo com os valores descritos na literatura. Fonseca et al. (2007) calcularam o valor da máxima velocidade específica de crescimento como sendo $0,56 \pm 0,02 \mathrm{~h}^{-1}$ (meio mineral definido, glicose com fonte de carbono, $30{ }^{\circ} \mathrm{C}$ ). 
Groeneveld et al. (2009), para esta linhagem e condições, estimaram esse valor como sendo $0,60 \mathrm{~h}^{-1}$, enquanto neste trabalho, o $\mu_{\text {máx }}$ calculado nas mesmas condições foi de 0,59 $\pm 0,01 \mathrm{~h}^{-1}$. Referente à linhagem K. marxianus CBS 397, dados não publicados do nosso grupo de pesquisa mostraram que o valor de $\mu_{\text {máx }}$ desta linhagem, cultivada nas mesmas condições descritas acima, foi de $0,60 \mathrm{~h}^{-1}$, enquanto neste trabalho foi calculado o valor de 0,55 $\pm 0,00 \mathrm{~h}^{-1}$. Além disto, Lages et al. (1999) calcularam um valor de $0,39 \mathrm{~h}^{-1}$ para a linhagem CBS 712 cultivada em meio complexo, enquanto neste trabalho, o $\mu_{\text {máx }}$ para a mesma linhagem foi de 0,32 $\pm 0,00 \mathrm{~h}^{-1}$. Neste caso, esta diferença pode ser explicada pela composição do meio, complexo no primeiro e definido no último caso. Para $K$. lactis CBS 2359, o valor de

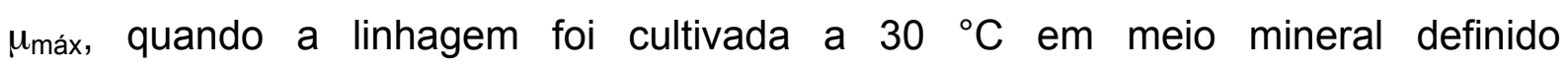
suplementado com glicose como fonte de carbono, foi de $0,37 \pm 0,00 \mathrm{~h}^{-1}$, enquanto em condições similares, Zeeman et al. (1999) calcularam 0,42 $\mathrm{h}^{-1}$ e Kiers et al. (1998), 0,40 $\mathrm{h}^{-1}$. Já linhagem de S. cerevisiae DS 28911, pertencente à espécie de leveduras mais estudada e muito utilizada como base de comparação, é capaz de crescer a uma velocidade específica máxima de $0,42 \mathrm{~h}^{-1}$ (van Hoek et al., 1998) no mesmo meio mineral descrito neste trabalho, usando glicose como fonte de carbono a $30{ }^{\circ} \mathrm{C}$. K. marxianus CBS 712 apresentou os valores mais baixos de $\mu_{\text {máx }}$ entre as linhagens da referida espécie. Além disso, essa linhagem não tem a capacidade de crescer em lactose, o que pode limitar sua aplicação em processos industriais, como na produção de proteínas heterólogas, que porventura possam utilizar substratos baratos como o soro de leite.

Também é possível verificar na Tabela 2.1, que as linhagens de $K$. marxianus cresceram mais rapidamente quando cultivadas a $37^{\circ} \mathrm{C}$ do que a $30{ }^{\circ} \mathrm{C}$. Fatichenti e Berardi (1987) mostraram que a linhagem K. marxianus SS-437 pode crescer em temperaturas entre $3{ }^{\circ} \mathrm{C}$ e $46{ }^{\circ} \mathrm{C}$, sendo que o pico de crescimento foi observado a $41,5^{\circ} \mathrm{C}$. Vários autores descrevem as temperaturas em torno de $40{ }^{\circ} \mathrm{C}$ como sendo aquelas nas quais células de $K$. marxianus se replicam num menor intervalo de tempo. Isso pode acarretar, num processo industrial, na redução dos custos de refrigeração em biorreatores, pois em grandes volumes, a transferência de calor torna-se complexa e uma maior quantidade de água refrigerada é necessária para resfriar adequadamente os tanques. Esse é um problema real em larga escala (Rouwenhorst et al., 1988; Hensing et al., 1995). 
Outra descoberta recente publicada por Groeneveld et al. (2009) é a capacidade evolutiva de $K$. marxianus em se tratando da velocidade específica de crescimento. Eles desenvolveram um sistema pH-auxostático no qual a pressão de seleção foi a velocidade de crescimento. Células de $K$. marxianus crescendo a um $\mu_{\text {máx }}$ de $0,60 \mathrm{~h}^{-1}$ foram capazes de crescer, após 50 gerações, a uma velocidade de $0,80 \mathrm{~h}^{-1}$. Os autores concluíram que esse incremento na velocidade é devido ao aparecimento de um mutante mais veloz, selecionado pelo ambiente. Em suma, $K$. marxianus CBS 6556 foi a linhagem que apresentou maior velocidade específica de crescimento na maioria das condições estudadas, com exceção do caso em que ela foi cultivada em lactose a $30^{\circ} \mathrm{C}$, situação na qual a linhagem K. marxianus CBS 397 cresceu mais rapidamente $\left(0,46 \pm 0,00 \mathrm{~h}^{-1}\right)$. Isso pode ser devido ao fato desta ter sido isolada do iogurte, enquanto aquela é nativa do pozol (bebida fermentada feita com milho e cacau), o qual não possui lactose em sua composição. Dessa forma, $K$. marxianus CBS 6556 pode ser uma boa alternativa para a produção de proteína unicelular, não apenas por crescer a altas velocidades, mas também por apresentar teor protéico na biomassa (55\% em média) maior que várias linhagens de $S$. cerevisiae (51\% em média), as quais são comumente utilizadas para essa finalidade (Fonseca et al., 2007). Limitações em processos envolvendo altas velocidades de crescimento podem ocorrer, como transferência insuficiente de oxigênio ou incapacidade de resfriamento do reator em culturas em altas concentrações, como descrito por Hensing et al., (1995), porém essa espécie apresenta a vantagem de oferecer a versatilidade de crescer a velocidades que possibilitam o encurtamento da duração da batelada, o que pode ser um ponto decisivo para a viabilidade do processo, inclusive para produção de proteínas heterólogas. 
Tabela 2.1. Crescimento, consumo de substrato e formação de metabólitos durante cultivos de $K$. marxianus e $K$. lactis. $\mu_{\max }$ é a máxima velocidade específica de crescimento; $\mu_{\mathrm{s}}$ significa a velocidade específica de consumo de substrato $\left[\mu_{S}=\mu_{\max }\left(\mathrm{Y}_{\mathrm{X} / \mathrm{S}}{ }^{\mathrm{EXP}}\right)^{-1}\right] ; \mathrm{Y}_{\mathrm{X} / \mathrm{S}}{ }^{\mathrm{GLO}}$ é a conversão global de substrato em biomassa; $\mathrm{Y}_{\mathrm{X} / \mathrm{S}}{ }^{\mathrm{EXP}}$ é a conversão de substrato em biomassa durante a fase exponencial; $\mathrm{T}^{\mathrm{EXP}}$ é a duração da fase exponencial. PT: número de pontos experimentais usado no cálculo de $\mu_{\max }$. As concentrações de metabólitos estão representadas pelo valor máximo obtido em cada cultivo. A determinação da inulinase extracelular ocorreu somente nos cultivos em sacarose. FC: fonte de carbono. Temp.: temperatura do cultivo. GLYC: glicerol; ACET: acetato; SUCC: succinato; PYR: piruvato; ETH: etanol. ND: não detectado. * A formação de metabólitos está mostrada por $\mathrm{Cmmol}$ de cada composto formado por $\mathrm{Cmol}$ da fonte de carbono consumida. Entre parênteses está o tempo relativo ao esgotamento da fonte de carbono que se obteve a concentração máxima do metabólito. Os experimentos foram realizados em duplicata e estão mostrados os valores médios. Em negrito estão os valores cujo coeficiente de variação (CV) foi maior de $10 \%$ [CV = Desvio padrão (média) ${ }^{-1}$ ]. Os gráficos das cinéticas de crescimento e produção de metabólitos extracelulares estão mostrados no apêndice $A$. Já os gráficos das cinéticas de produção de inulinase extracelular estão no apêndice $B$.

\begin{tabular}{|c|c|c|c|c|c|c|c|c|c|c|c|c|c|}
\hline Linhagem & $\begin{array}{c}\text { FC, } \\
\text { Temp. }\end{array}$ & $\begin{array}{l}\mu_{\max } \\
\left(\mathrm{h}^{-1}\right)\end{array}$ & $\begin{array}{c}\mu_{\mathrm{s}} \\
\left(\mathrm{h}^{-1}\right)\end{array}$ & $\begin{array}{l}Y_{\mathrm{X} / \mathrm{S}} \\
\mathrm{GLO}\end{array}$ & $\begin{array}{l}Y_{\mathrm{X} / \mathrm{S}} \\
\mathrm{EXP}\end{array}$ & $\begin{array}{l}\mathrm{T}^{\mathrm{EXP}} \\
\text { (h) }\end{array}$ & PT & GLYC* & ACET* & SUCC* & PYR* & ETH* $^{*}$ & $\begin{array}{l}\text { Inulinase } \\
\text { (U/mgDW) }\end{array}$ \\
\hline \multirow{6}{*}{$\begin{array}{l}\text { K. } \\
\text { marxianus } \\
\text { CBS6556 }\end{array}$} & $\begin{array}{l}\text { GLC, } \\
30^{\circ} \mathrm{C}\end{array}$ & 0.59 & 1.34 & 0.44 & 0.44 & 6 & 8 & $17.4(0)$ & $9.8(-1)$ & ND & $6.5(0)$ & $19.4(0)$ & - \\
\hline & $\begin{array}{l}\text { GLC, } \\
37^{\circ} \mathrm{C}\end{array}$ & 0.66 & 1.43 & 0.45 & 0.44 & 5 & 7 & $25.0(0)$ & $4.8(0)$ & $2.6(0)$ & $4.7(0)$ & $40.3(0)$ & - \\
\hline & $\begin{array}{l}\text { LAC, } \\
30^{\circ} \mathrm{C}\end{array}$ & 0.40 & 0.72 & 0.54 & 0.55 & 8 & 8 & 10.2 & 0.4 & 0.4 & 0.9 & ND & - \\
\hline & $\begin{array}{l}\text { LAC, } \\
37^{\circ} \mathrm{C}\end{array}$ & 0.63 & 1.19 & 0.53 & 0.53 & 6 & 8 & $30.4(0)$ & $5.6(0)$ & $2.3(0)$ & $5.3(0)$ & $45.5(0)$ & - \\
\hline & $\begin{array}{l}\text { SUC, } \\
30^{\circ} \mathrm{C}\end{array}$ & 0.58 & - & 0.39 & - & 6 & 9 & $10.6(0)$ & $21.0(-1)$ & $1.2(0)$ & $4.1(0)$ & $72.9(0)$ & 1.24 \\
\hline & $\begin{array}{l}\text { SUC, } \\
37^{\circ} \mathrm{C}\end{array}$ & 0.70 & - & 0.49 & - & 4 & 6 & $12.6(-.5)$ & $3.8(-.5)$ & ND & ND & $17.8(-.5)$ & 1.65 \\
\hline \multirow[t]{6}{*}{$\begin{array}{l}K . \\
\text { marxianus } \\
\text { CBS397 }\end{array}$} & $\begin{array}{l}\text { GLC, } \\
30^{\circ} \mathrm{C}\end{array}$ & 0.55 & 1.28 & 0.42 & 0.40 & 7 & 7 & $10.4(0)$ & $16.5(-1)$ & ND & $6.4(0)$ & $75.4(0)$ & - \\
\hline & $\begin{array}{l}\mathrm{GLC} \\
37^{\circ} \mathrm{C}\end{array}$ & 0.52 & 1.53 & 0.41 & 0.34 & 5 & 5 & $8.9(0)$ & $12.4(0)$ & $0.8(-1)$ & $3.6(0)$ & $73.3(0)$ & - \\
\hline & $\begin{array}{l}\text { LAC, } \\
30^{\circ} \mathrm{C}\end{array}$ & 0.46 & 1.02 & 0.40 & 0.42 & 8 & 8 & $10.7(-1)$ & $6.0(-1)$ & $6.9(-1)$ & ND & $92.3(-1)$ & - \\
\hline & $\begin{array}{l}\text { LAC, } \\
37^{\circ} \mathrm{C}\end{array}$ & 0.59 & 1.55 & 0.40 & 0.38 & 6 & 7 & $10.5(0)$ & $15.3(-1)$ & $2.3(0)$ & $4.3(0)$ & $85.8(-1)$ & - \\
\hline & $\begin{array}{l}\text { SUC, } \\
30^{\circ} \mathrm{C}\end{array}$ & 0.52 & - & 0.39 & - & 7 & 6 & $13.4(0)$ & $26.6(0)$ & $1.5(0)$ & $2.2(1)$ & $44.6(0)$ & 0.59 \\
\hline & $\begin{array}{l}\text { SUC, } \\
37^{\circ} \mathrm{C}\end{array}$ & 0.67 & - & 0.47 & - & 6 & 5 & $22.8(0)$ & $3.4(0)$ & ND & ND & $0.8(0)$ & 0.83 \\
\hline \multirow[t]{5}{*}{$\begin{array}{l}\text { K. } \\
\text { marxianus } \\
\text { CBS712 }\end{array}$} & $\begin{array}{l}\text { GLC, } \\
30^{\circ} \mathrm{C}\end{array}$ & 0.31 & 0.75 & 0.45 & 0.46 & 11 & 10 & $10.2(0)$ & $5.1(0)$ & $1.2(0)$ & $1.3(0)$ & $2.3(0)$ & - \\
\hline & $\begin{array}{l}\text { GLC, } \\
37^{\circ} \mathrm{C} \\
\mathrm{LAC}\end{array}$ & 0.47 & 0.85 & 0.58 & 0.55 & 8 & 8 & $9.7(0)$ & $1.5(-3)$ & $3.5(0)$ & $1.2(0)$ & ND & - \\
\hline & $\begin{array}{l}30^{\circ} \mathrm{C} \\
\text { LAC, } \\
37^{\circ} \mathrm{C}\end{array}$ & & & & & & & -Não hol & crescimen & & & ---- & \\
\hline & $\begin{array}{l}\text { SUC, } \\
30^{\circ} \mathrm{C}\end{array}$ & 0.33 & - & 0.45 & - & 10 & 11 & $7.2(0)$ & $6.6(0)$ & ND & ND & ND & 0.46 \\
\hline & $\begin{array}{l}\text { SUC, } \\
37^{\circ} \mathrm{C}\end{array}$ & 0.45 & - & 0.59 & - & & & $8.2(0)$ & $3.5(0)$ & $3.0(-2)$ & $4.4(0)$ & ND & 0.50 \\
\hline \multirow[t]{4}{*}{$\begin{array}{l}\text { K. lactis } \\
\text { CBS2359 }\end{array}$} & $\begin{array}{l}\mathrm{GLC} \\
30^{\circ} \mathrm{C} \\
\mathrm{GLC}\end{array}$ & 0.37 & 0.78 & 0.49 & 0.47 & 10 & 10 & $3.3(-4)$ & ND & ND & $6.1(-4)$ & ND & - \\
\hline & $\begin{array}{l}37^{\circ} \mathrm{C} \\
\mathrm{LAC}, \\
30^{\circ} \mathrm{C} \\
\text { LAC, }\end{array}$ & 0.37 & 1.16 & 0.30 & 0.32 & 10 & 11 & $16.9(0)$ & $9.2(-3)$ & $1.6(0)$ & ND & $78.6(0)$ & - \\
\hline & $\begin{array}{l}37^{\circ} \mathrm{C} \\
\text { SUC, } \\
30^{\circ} \mathrm{C} \\
\text { SUC, }\end{array}$ & 0.40 & - & 0,52 & - & 10 & 11 & $33,4(+1)$ & ND & $5,8(-1)$ & ND & $80,4(+1)$ & 0,00 \\
\hline & $37^{\circ} \mathrm{C}$ & & & & & & & & & & & & \\
\hline
\end{tabular}




\subsection{Conversão de substrato em biomassa}

A conversão de substrato em biomassa $\left(\mathrm{Y}_{\mathrm{x} / \mathrm{S}}\right)$ é um parâmetro importante da fisiologia celular. A eficiência da célula ao transformar substrato em biomassa é resumida por esse coeficiente. Neste trabalho, são mencionados dois valores de $\mathrm{Y}_{\mathrm{X} / \mathrm{S}}$. O primeiro é o coeficiente de conversão global $\left(\mathrm{Y}_{\mathrm{X} / \mathrm{S}}{ }^{\mathrm{GLO}}\right)$, o qual corresponde à biomassa formada durante o cultivo até o esgotamento da principal fonte de carbono. O outro coeficiente é a conversão de substrato em biomassa durante a fase exponencial de crescimento $\left(\mathrm{Y}_{\mathrm{X} / \mathrm{S}}{ }^{\mathrm{EXP}}\right)$. Na tabela 2.1, $\mathrm{Y}_{\mathrm{X} / \mathrm{S}}{ }^{\mathrm{EXP}}$ não está representado nos cultivos em sacarose, pois este substrato é hidrolisado no meio extracelular e a glicose e a frutose resultantes não são consumidas na mesma velocidade em que a sacarose é hidrolisada.

Analisando as quatro linhagens cultivadas em glicose a $30{ }^{\circ} \mathrm{C}$ (Tabela 2.1), $\mathrm{K}$. marxianus CBS 397 apresentou o menor valor de $Y_{X / S}{ }^{\text {EXP. }}: 0,40 \pm 0,02 \mathrm{~g} \mathrm{MS} / \mathrm{g}$ GLC. Esse valor mais baixo pode ser explicado por uma maior formação de etanol, sugerindo-se que pode ter havido limitação de oxigênio. Mesmo os valores de $Y_{x / s}$ de K. marxianus CBS 397 sendo relativamente menores que o das outras três linhagens, quando se comparam os valores desta levedura com fatores de conversão de substrato em biomassa de $S$. cerevisiae crescendo a velocidades próximas ao valor de seu $\mu_{\text {máx }}$ os valores da primeira são drasticamente maiores. Postma et al. (1989), para S. cerevisiae CBS 8066, calcularam o fator de conversão de substrato em biomassa como $0,50 \mathrm{~g} \mathrm{MS} / \mathrm{g}$ GLC quando o cultivo foi conduzido a $D=0,38 \mathrm{~h}^{-1}$. Quando $D$ foi aumentado para $0,48 \mathrm{~h}^{-1}, \mathrm{Y}_{\mathrm{X} / \mathrm{S}}{ }^{\mathrm{GLO}}$ diminuiu para $0,18 \mathrm{~g}$ MS/g GLC. Nissen et al. (2000) reportaram que, para S. cerevisiae TN1 crescendo a $\mu_{\text {máx }}$ de $0,41 \mathrm{~h}^{-1}$ em cultivos batelada e utilizando o mesmo meio mineral deste trabalho, a conversão global de substrato em biomassa foi de $0,17 \mathrm{~g} \mathrm{MS} / \mathrm{g} \mathrm{GLC}$. Esses exemplos mostram uma vantagem de $K$. marxianus quando comparada com $S$. cerevisiae no que se refere à conversão de substrato em biomassa. Aquela tem a capacidade de crescer a altas velocidades específicas com alto rendimento em biomassa, enquanto esta, uma espécie Crabtree-positiva, produz uma alta quantidade de metabólitos, principalmente etanol. Além da menor eficiência energética que a produção de etanol representa, o acúmulo desta molécula no meio 
pode aumentar a permeabilidade da membrana citoplasmática, pela sua inserção no interior hidrofóbico da mesma, aumentando a polaridade dessa região, enfraquecendo a barreira hidrofóbica e assim ocasionando a perda de compostos intracelulares importantes, como nucleotídeos e aminoácidos (Salgueiro et al., 1988). O etanol também pode contribuir para o aumento da penetração de ácidos fracos através da membrana citosólica, intensificando o chamado efeito desacoplador de ácidos fracos, o que aumenta o gasto de energia para manutenção do $\mathrm{pH}$ intracelular (Verduyn et al., 1991).

De acordo com a Tabela 2.1, K. marxianus CBS 6556 apresentou conversão de $0,54 \mathrm{~g} \mathrm{MS} / \mathrm{g} \mathrm{LAC} \mathrm{a} 30^{\circ} \mathrm{C}$. Esse valor está próximo ao teórico $(0,60 \mathrm{~g} \mathrm{MS} / \mathrm{g} \mathrm{LAC})$, de acordo com o modelo proposto por Longhi et al. (2004). Para esta linhagem, rendimentos mais altos foram obtidos em lactose e os mais baixos em sacarose. Já no caso da K. marxianus CBS 712, é clara a maior conversão de substrato em biomassa quando as células foram cultivadas a $37^{\circ} \mathrm{C}$ em vez de em $30^{\circ} \mathrm{C}$, tanto em glicose, como em sacarose.

Na Figura 2.1 é possível verificar a relação entre a formação de biomassa e a produção de metabólitos. Geralmente, com uma alta formação de metabólitos, a conversão em biomassa diminui. Quando as linhagens de K. marxianus foram cultivadas a $37{ }^{\circ} \mathrm{C}$, a produção de metabólitos aumentou. Isso provavelmente ocorreu devido à maior velocidade específica nessa temperatura. Segundo Blank e Sauer (2004), a repressão por glicose exercida sobre o ciclo dos ácidos tricarboxílicos é regulada pela velocidade específica de crescimento e de consumo de glicose. De fato, Fonseca et al. (2007) reforçaram essa assertiva, já que foram capazes de observar uma pequena formação de etanol quando $K$. marxianus cresceu a $D=0,25 \mathrm{~h}^{-1}$, enquanto a $D=0,1 \mathrm{~h}^{-1}$, não foi observada formação de metabólitos. 


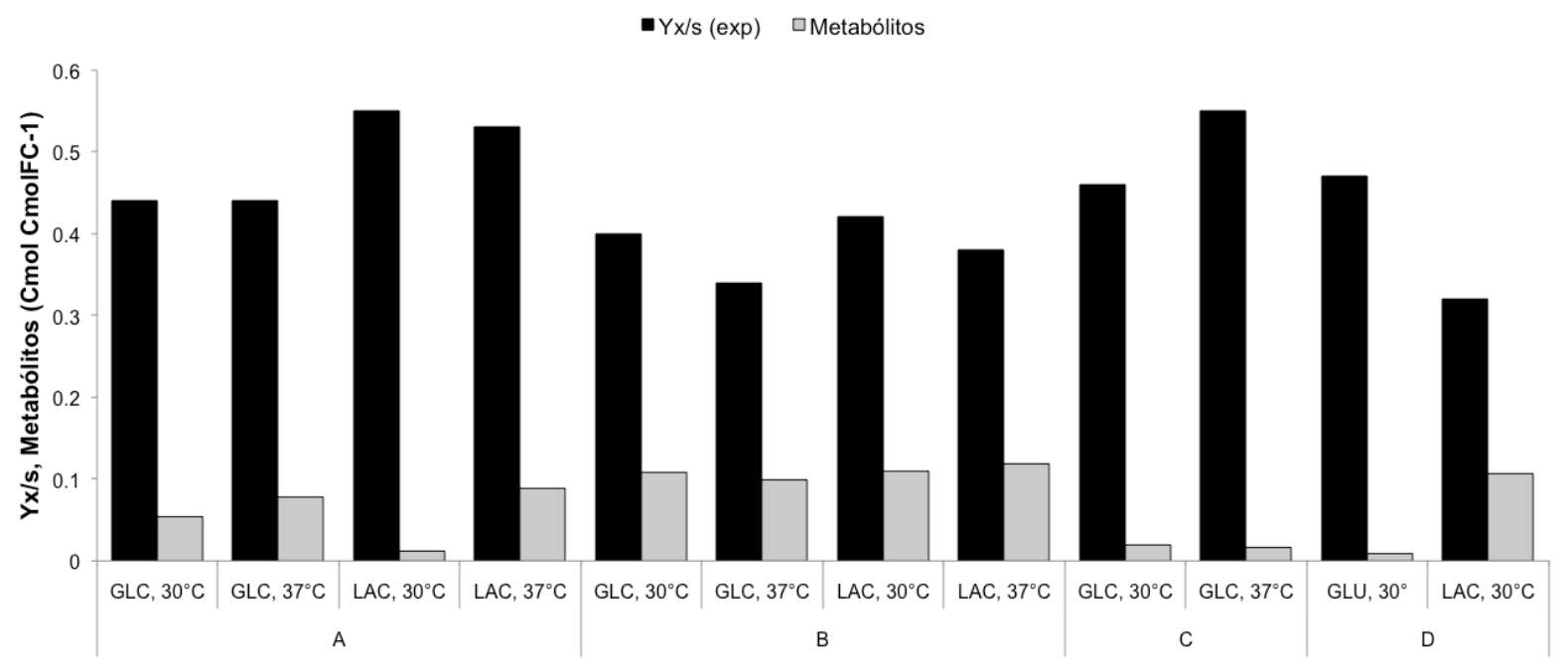

Figura 2.1. $Y_{X / S}{ }^{E X P}$ e a recuperação do carbono presente no substrato em metabólitos extracelulares (C-moles da soma dos metabólitos / C-moles da fonte de carbono ). A: K. marxianus CBS 6556; B: K. marxianus CBS 397; C: K. marxianus CBS 712; D: K. lactis CBS 2359.

\subsection{Formação de metabólitos extracelulares}

Em cultivos nos quais a glicose é a única fonte de carbono, a maioria das espécies de leveduras apresentam fermentação alcoólica quando em condições de limitação de oxigênio. Algumas espécies, como a levedura modelo $S$. cerevisiae, utilizam a via fermentativa para produção de energia mesmo sob condições aeróbicas. Isto somente não ocorre se três condições forem obedecidas simultaneamente: baixa concentração de glicose, oxigênio não-limitante e baixa velocidade específica de crescimento. Experimentalmente, esta situação pode ser obtida durante quimiostatos aeróbios, limitados por glicose, a baixos valores de vazão específica. Esse fenômeno de fermentação em aerobiose plena é conhecido como efeito Crabtree (Crabtree, 1929; De Deken, 1966). Por outro lado, as leveduras do gênero Kluyveromyces não apresentam esse efeito em aerobiose, embora seja muito importante considerar as condições do cultivo (aeração, fonte de carbono, fase de cultivo e limitação de nutrientes) para classificar a levedura como sendo Crabtree positiva ou negativa (González-Siso et al., 2000).

A formação de etanol é geralmente acompanhada da produção de outros metabólitos, inclusive ácidos orgânicos fracos, como é possível observar no apêndice $A$. Esses ácidos podem difundir do meio extracelular para o citosol na 
forma não dissociada através da membrana plasmática. Uma vez no citosol, a maior parte das moléculas vai dissociar, devido ao pH do meio ser mais alto (em torno de 7,0), quando comparado ao pK dos ácidos orgânicos, resultando na transferência de prótons do meio para o citosol. Para evitar uma alta concentração de prótons intracelular, a célula gasta energia para bombear o excesso para o ambiente externo (Verduyn et al., 1992). Neste trabalho, foi observada produção extracelular de acetato e também dos ácidos succínico e pirúvico em menores concentrações.

Além da formação de ácidos fracos, as células também produzem glicerol, o que pode ocorrer em aerobiose (Nissen et al., 1997) e também sob altas velocidades de crescimento (Postma et al., 1989). A formação de glicerol faz parte de um mecanismo para a célula reoxidar o excesso de NADH formado (Overkamp et al., 2002), exercendo a mesma função quando o acetaldeído é reduzido a etanol (Wang et al., 2001). Além disso, o glicerol formado é acumulado dentro da célula sob condições de estresse, situação na qual esse componente torna-se um eficiente protetor contra a lise celular.

Apesar de não ser possível garantir, nos cultivos realizados, condições de plena aerobiose, nos casos em que a glicose foi a única fonte de carbono, é possível constatar o status Crabtree-negativo de K. marxianus (Bellaver et al., 2004; Kiers et al.,1998; Fonseca et al., 2007), devido à pequena ou nula formação de etanol. A exceção ocorreu com a linhagem K. marxianus CBS397, em que houve significativa produção de etanol tanto a $30^{\circ} \mathrm{C}$ quanto a $37^{\circ} \mathrm{C}$. Sugere-se que durante o cultivo houve escassez de oxigênio dissolvido no meio, levando a levedura a desviar seu metabolismo para a via fermentativa. Um estudo feito por Mahmoud e Kisikowski (1982) revelou que dentre cinco congêneres, a linhagem K. marxianus CBS397 apresentou maior produção de etanol, mas não havia informação sobre a garantia de plena aerobiose. Entretanto, estudos recentes ainda não publicados pelo nosso grupo mostram que essa mesma linhagem é capaz de crescer em plena aerobiose sem a formação de etanol, confirmando seu status Crabtree-negativo. K. marxianus CBS 6556 também exibiu uma pequena formação de metabólitos em ambas os cultivos em glicose (a $30{ }^{\circ} \mathrm{C}$ e $37^{\circ} \mathrm{C}$ ), atingindo o máximo de concentração no momento em que se tornou escasso o substrato e a concentração celular era máxima. A linhagem que apresentou menor formação de metabólitos foi destacadamente a K. marxianus CBS 712. Não obstante, também apresentou 
valores altos de $Y x / s$, porém baixos de $\mu$ máx (Tabela 2.1). Não é possível inferir que a baixa formação de metabólitos, neste caso, seja intrínseca à linhagem, pois os valores mais baixos de velocidade de crescimento da linhagem $K$. marxianus CBS712 fizeram com que não houvesse escassez de oxigênio no meio. Conseqüentemente, a formação de metabólitos foi menor que nas linhagens que apresentaram maior $\mu$ máx.

Nos cultivos em lactose a $30{ }^{\circ} \mathrm{C}$, tanto a linhagem $K$. marxianus CBS 6556 quanto a linhagem K. marxianus CBS397 apresentaram crescimento com reduzida formação de metabólitos. Em contrapartida, sua congênere K. lactis CBS 2359 apresentou acentuada formação de etanol nessa condição, em torno de $21 \mathrm{mM}$. Relatos em que ocorreu metabolismo fermentativo sob aerobiose em $K$. lactis CBS 2359 são baseados em cultivos em frascos Erlenmeyer (Mulder et al., 1995) ou quando foi utilizado meio complexo (González-Siso et al., 1996). Kiers et al. (1998) descrevendo a mesma linhagem de $K$. lactis no mesmo meio mineral definido que este trabalho, relataram problemas de falta de oxigênio nos cultivos frascos Erlenmeyer. Quando cultivadas em reator, as células não apresentaram produção de etanol. Isso leva a crer que as células cresceram sob hipóxia durante uma fase do cultivo em Erlenmeyer. Outra hipótese que pode explicar a formação de etanol, é a que o cultivo pode ter sido limitado por ácido nicotínico. Kiers et al. (1998) verificaram que no mesmo meio mineral definido, cultivos de $K$. lactis a altas velocidades específicas de crescimento foram limitados por essa vitamina. A velocidades de crescimento mais baixas, o cultivo voltou a ser limitado pela fonte de carbono. Sugere-se que umas dessas alternativas possam ter ocorrido quando a linhagem CBS 2359 cresceu em sacarose. K. lactis CBS 2359 não cresce a $37^{\circ} \mathrm{C}$.

Nos cultivos em que a sacarose foi utilizada como única fonte de carbono, as altas velocidades de crescimento acarretaram em uma maior produção de glicerol e, além disso, a alta demanda de oxigênio resultou em hipóxia e conseqüentemente, em formação de etanol. Essa hipótese é reforçada pois o etanol fora somente detectado nas últimas horas do crescimento exponencial, quando a concentração de biomassa era mais alta, resultando em uma maior demanda de oxigênio. Assim como ocorreu nos cultivos em glicose, a linhagem K. marxianus CBS 712 apresentou os menores valores de formação de metabólitos por carbono consumido (19 C-mmol/C-mol a $30^{\circ} \mathrm{C}$ e $16 \mathrm{C}-\mathrm{mmol} / \mathrm{C}-\mathrm{mol}$ a $37^{\circ} \mathrm{C}$ ); seguida pelas linhagens $\mathrm{K}$. 
marxianus CBS 6556 (53 C-mmol/C-mol a $30{ }^{\circ} \mathrm{C}$ e $77 \mathrm{C}-\mathrm{mmol} / \mathrm{C}-\mathrm{mol}$ a $37^{\circ} \mathrm{C}$ ) e $\mathrm{K}$. marxianus CBS 397 (109 C-mmol/C-mol a $30^{\circ} \mathrm{C}$ e $99 \mathrm{C}-\mathrm{mmol} / \mathrm{C}-\mathrm{mol}$ a $37^{\circ} \mathrm{C}$ ).

\subsection{Produção de inulinase extracelular}

A atividade extracelular da enzima inulinase foi medida em cada amostra dos cultivos em que a sacarose foi utilizada como fonte de carbono (os gráficos das cinéticas estão apresentados no apêndice B). Este foi mais um ponto dessa investigação sobre a fisiologia de diferentes linhagens de K. marxianus. Estudos sobre a secreção de proteínas homólogas podem ajudar a selecionar uma linhagem para ser usada como hospedeira na síntese de proteínas heterólogas. É sabido que a eficiência na secreção de proteínas pode variar a cada caso, mas um ponto de partida é sempre necessário para executar essa seleção.

Sabe-se que o promotor do gene (INU1) do gene que codifica para a enzima inulinase é principalmente induzido na presença da inulina, um polissacarídeo composto basicamente de frutose (Kushi et al., 2000). Sacarose e frutose também são conhecidos como indutores. Parekh e Margaritis (1985) relataram que a atividade extracelular de inulinase quando $K$. marxianus UCD foi cultivada em meio complexo, utilizando inulina como fonte de carbono, foi 3,3 vezes maior que a detectada em meio contendo sacarose como substrato. Já no mesmo meio mineral que o utilizado neste trabalho, Rouwenhorst et al. (1988), utilizando K. marxianus CBS 6556, determinaram uma atividade $10 \%$ maior em meio contendo inulina em relação ao meio contendo sacarose em cultivos contínuos. Neste trabalho, sacarose foi utilizada como indutor da formação de inulinase, pois essa fonte de carbono está presente em matérias-primas de baixo custo, principalmente no Brasil, as quais podem ser exploradas em futuras aplicações industriais.

A produção de inulinase em cultivos contínuos diminui à medida que se aumenta a taxa de diluição (Rouwenhorst et al., 1988; Kushi et al., 2000). Como a regulação do gene INU1 ocorre via indução e repressão (GrootWassink e Hewitt, 1983; Cruz-Guerrero et al., 2006), a diminuição na atividade de inulinase com o aumento da taxa de diluição é principalmente causada pelo aumento do açúcar 
residual em taxas de diluição mais altas (Rouwenhorst, et al., 1988). Essa relação é claramente demonstrada na tabela 2.2.

Tabela 2.2. Relação entre taxa de diluição e atividade de inulinase extracelular produzida por $K$. marxianus.

\begin{tabular}{|c|c|c|c|c|}
\hline Fonte de Carbono & $\begin{array}{c}\text { Taxa de } \\
\text { Diluição }\left(\mathrm{h}^{-1}\right)\end{array}$ & $\begin{array}{l}\text { Atividade de } \\
\text { Inulinase }\end{array}$ & Unidade & Referência \\
\hline Inulina ${ }^{1}$ & 0,05 & 58 & $\mathrm{U}(\mathrm{mgMS})^{-1}$ & Rouwenhorst et al., 1988 \\
\hline Inulina ${ }^{1}$ & 0,15 & 25 & $U(\mathrm{mgMS})^{-1}$ & Rouwenhorst et al., 1988 \\
\hline Sacarose $^{1}$ & 0,10 & 52 & $U(\mathrm{mgMS})^{-1}$ & Rouwenhorst et al., 1988 \\
\hline Sacarose ${ }^{1}$ & 0,80 & 2,0 & $U(\mathrm{mgMS})^{-1}$ & Rouwenhorst et al., 1988 \\
\hline Sacarose $^{2}$ & 0,05 & 107 & $\mathrm{U} \mathrm{ml}^{-1}$ & Kushi et al., 2000 \\
\hline Sacarose $^{2}$ & 0,10 & 105 & $\mathrm{U} \mathrm{ml}^{-1}$ & Kushi et al., 2000 \\
\hline Sacarose $^{2}$ & 0,15 & 67 & $\mathrm{U} \mathrm{ml}^{-1}$ & Kushi et al., 2000 \\
\hline Sacarose $^{2}$ & 0,20 & 65 & $\mathrm{U} \mathrm{ml}^{-1}$ & Kushi et al., 2000 \\
\hline Sacarose $^{2}$ & 0,25 & 51 & $\mathrm{U} \mathrm{ml}^{-1}$ & Kushi et al., 2000 \\
\hline Sacarose $^{2}$ & 0,30 & 9 & $\mathrm{U} \mathrm{ml}^{-1}$ & Kushi et al., 2000 \\
\hline Sacarose $^{2}$ & 0,35 & 1,9 & $\mathrm{Uml}^{-1}$ & Kushi et al., 2000 \\
\hline Sacarose $^{2}$ & 0,40 & 0,84 & $\mathrm{U} \mathrm{ml}^{-1}$ & Kushi et al., 2000 \\
\hline Sacarose $^{2}$ & 0,45 & 0,81 & $\mathrm{Uml}^{-1}$ & Kushi et al., 2000 \\
\hline
\end{tabular}

Meio mineral definido

${ }^{2}$ Meio complexo

K. marxianus CBS 6556 apresentou maior atividade específica de inulinase extracelular durante seu crescimento em relação às outras duas linhagens estudadas. A $30^{\circ} \mathrm{C}$, chegou a um valor médio máximo de $1,24 \mathrm{U} / \mathrm{mgMS}$ e a $37^{\circ} \mathrm{C}$ observou-se atividade de 1,65 U/mgMS. As linhagens $\mathrm{K}$. marxianus CBS 397 e $\mathrm{K}$. marxianus CBS 712 apresentaram, respectivamente, atividades máximas de 0,59 U/ mgMS e $0,46 \mathrm{U} / \mathrm{mgMS}$ a $30^{\circ} \mathrm{C}$. Já na temperatura de $37^{\circ} \mathrm{C}$, observou-se atividade de 0,83 U/mgMS e 0,50 U/mgMS, respectivamente. Rouwenhorst et al. (1988) no mesmo meio mineral, relataram atividade de 2,0 U/mgMS para $K$. marxianus CBS 6556 crescendo a uma velocidade específica de $0,8 \mathrm{~h}^{-1}$. Porém, apenas cerca de $50 \%$ desse valor era relativo à enzima extracelular, concordando com os dados apresentados neste trabalho.Além da fração de inulinase existente no sobrenadante, Rouwenhorst et al. (1988) descrevem mais duas frações possíveis, nas quais pode ser encontrada inulinase: ligada à parede celular e ligada à célula. Essas duas frações não foram consideradas neste trabalho, pois a intenção era de estimar a capacidade de secreção total da enzima, ou seja, até a sua forma extracelular, no sobrenadante.

Sugere-se que a temperatura de cultivo exerce influência sobre a produção de inulinase. Rouwenhorst et al. (1988), estudando cultivos a uma larga faixa de temperaturas, perceberam que a atividade enzimática é maior quanto mais próxima 
a levedura estiver da sua temperatura ótima de crescimento, ou seja, entre $37{ }^{\circ} \mathrm{C} \mathrm{e}$ $42{ }^{\circ} \mathrm{C}$. Mazutti et al. (2005) relataram uma produção de inulinase mais alta quando K. marxianus NRRL y7551 cresceu a $36{ }^{\circ} \mathrm{C}$. Da mesma maneira, no presente, as atividades mais altas foram obtidas a $37^{\circ} \mathrm{C}$, para as três linhagens estudadas. Já em outros organismos, a temperatura ótima varia a cada caso. Em Pseudomonas sp., maior produção de inulinase foi alcançada a $42{ }^{\circ} \mathrm{C}$ e em Xanthomonas sp., a $37{ }^{\circ} \mathrm{C}$ (Park e Yun, 2001). Derycke e Vandamme (1984) publicaram que, em Penicillium $s p$. atividade mais alta de inulinase foi detectada em cultivos a $35^{\circ} \mathrm{C}$.

A linhagem K. lactis CBS 2359 foi também testada quanto à produção de inulinase, como um controle negativo, já que não era esperada produção da enzima nesta espécie. K. lactis é capaz de utilizar sacarose como fonte de carbono, porém a sua hidrólise é feita pela enzima invertase, codificada pelo gene INV1, que apresenta uma alta homologia com a invertase de $S$. cerevisiae (Fernandes et al., 1995).

\section{Conclusões}

O estudo comparativo cumpriu o objetivo de comparar e identificar variações fisiológicas intra-específicas em $K$. marxianus e comparar parâmetros fisiológicos desta espécie com $K$. lactis.

A linhagem K. marxianus CBS 6556 foi a que melhor reuniu as características esperadas para um hospedeiro de expressão heteróloga. Apresentou velocidade de crescimento específica e rendimento de substrato em biomassa, na maioria das condições estudadas, superiores aos valores apresentados pelas outras linhagens. Também apresentou maior produção e secreção da enzima homóloga inulinase, se comparada às demais linhagens de K. marxianus estudadas. Dessa forma, essa foi a linhagem selecionada para a segunda etapa do trabalho, a clonagem dos genes da glicose oxidase de Aspergillus niger e da esterase de Thermus thermophillus. Os estudos de biologia molecular foram realizados também na linhagem $K$. lactis PM53C (K. lactis CBS 2359 MATa uraA Rag'), já que esta espécie é considerada um organismo modelo e é referência para leveduras dentro do gênero Kluyveromyces (Lachance, 2007). 
Capítulo 3

\section{Construção de Sistemas de Expressão Heteróloga em $K$. marxianus e $K$. lactis}




\section{CONSTRUÇÃO DE SISTEMAS DE EXPRESSÃO HETERÓLOGA EM Kluyveromyces marxianus E Kluyveromyces lactis}

Saul Nitsche Rocha ${ }^{1}$, Andreas Karoly Gombert ${ }^{1}$, María Esperanza Cerdán ${ }^{2}$, María Isabel González-Siso²

${ }^{1}$ Departamento de Engenharia Química, Universidade de São Paulo, CP 61548, 05424-970, São Paulo-SP, Brasil

${ }^{2}$ Departamento de Bioloxía Celular e Molecular, Facultade de Ciencias, Universidade da Coruña, Campus da Zapateira s/n, 15071-A Coruña, Espanha

\section{Resumo}

Neste trabalho, foram construídos sistemas para expressão heteróloga de uma esterase (EST) de Thermus thermophilus, com potencial de aplicação industrial, pela sua capacidade de modificação de ácidos graxos a altas temperaturas, o que ocorre por exemplo na produção de biodiesel. Também foram gerados sistemas para a expressão heteróloga da proteína-modelo glicose oxidase (GOX) de Aspergillus niger, enzima muito utilizada na confecção de biossensores para medição da concentração de glicose no sangue. Ambas as proteínas foram expressas nas leveduras Kluyveromyces marxianus e Kluyveromyces lactis. Dois sistemas epissomais foram montados. No primeiro, utilizou-se o promotor e terminador do gene PGK (fosfoglicerato quinase) de $S$. cerevisiae e o sinal de secreção k1 de $K$. lactis. O outro sistema epissomal construído utilizou promotor, sinal de secreção e terminador do gene INU1 (inulinase) de K. marxianus. Ambos sistemas epissomais foram baseados no plasmídeo pSPGK1, que possui uma origem de replicação $S 11$ (funcional em $K$. marxianus e $K$. lactis) e a marca de seleção URA3. Cassetes de expressão contendo os genes da esterase ou da GOX, sob controle do promotor de INU1 foram também inseridos num vetor integrativo (pNADFL11), o qual possui a capacidade de se integrar ao genoma da levedura no locus do gene URA3. Resultados preliminares de expressão das duas proteínas heterólogas, nos três sistemas de expressão e nas duas leveduras estudadas (totalizando doze construções) são apresentados. 


\section{Introdução}

Uma classe de vetores epissomais utilizados para expressão de proteínas heterólogas são plasmídeos circulares que possuem uma origem de replicação de leveduras. A natureza dessa origem de replicação é um fator determinante à estabilidade desses plasmídeos. Vetores baseados nas origens de replicação ARS (seqüências de replicação autônomas, sigla em inglês), derivadas dos cromossomos de leveduras, estão disponíveis para todas as espécies de leveduras (Romanos et al., 1992). Apesar de alguns desses vetores possuírem capacidade de replicar-se em um grande número de cópias, sua estabilidade geralmente é muito baixa (as perdas são da ordem de $10 \%$ por geração). Essa baixa estabilidade torna os plasmídeos derivados de ARS inadequados para aplicações em processos de larga escala (Hensing et al., 1995).

Um grande avanço na pesquisa de biologia molecular em leveduras do gênero Kluyveromyces foi o descobrimento do plasmídeo pKD1 na espécie Kluyveromyces drosophilarum (Falcone et al., 1986). Esse plasmídeo de 4,8 kb e 1,65 $\mu \mathrm{m}$ possui uma organização similar ao plasmídeo $2 \mu$ (Futcher et al., 1988) do gênero Saccharomyces (Chen et al., 1986), e pode replicar-se em uma variedade de espécies do gênero Kluyveromyces, inclusive K. lactis (Fleer et al., 1991) e K. marxianus (Bartkeviciute et al., 2000). Em células cultivadas na ausência de pressão seletiva, o plasmídeo pKD1 pode ser mantido em K. lactis (Bianchi et al., 1987), porém sua estabilidade depende da linhagem hospedeira (Hensing et al., 1995). Mais tarde, foi demonstrado que a inserção do gene de resistência à canamicina, do gene URA3 de $S$. cerevisiae, a origem de replicação de $E$. coli e o gene que confere resistência à ampicilina, ao plasmídeo pKD1, resultaram em um vetor versátil que pode transformar e ser mantido em $K$. marxianus CBS 6556 e CBS 712, embora com baixa eficiência de transformação (Chen et al., 1989). Dessa forma, plasmídeos baseados no pKD1 tornaram-se a escolha mais comum para inserir seqüências heterólogas de DNA em K. marxianus (Fonseca et al., 2008).

Apesar de a técnica de engenharia genética utilizando plasmídeos de replicação autônoma ser conveniente, a estabilidade dos plasmídeos após gerações é limitada (Bartkeviciute et al., 2000). Essa instabilidade é fator crucial em processos 
industriais. Uma alternativa a essa técnica é a utilização de plasmídeos integrativos. Dessa forma, uma estabilidade muito maior pode ser alcançada em sistemas de integração por recombinação no DNA cromossomal da levedura . A integração de fragmentos de DNA num organismo requer a ação de um mecanismo de reparação de cadeia dupla (DSB- double-strand break mechanism). Em Eukarya, dois mecanismos foram identificados: a recombinação homóloga (homologous recombination, HR), que resulta numa integração direcionada, e a ligação de extremidades não homólogas (non-homologous end joining, NHEJ), que resulta numa integração casual. As diferenças na eficiência de integração direcionada nos diferentes organismos podem ser explicadas pela maior atividade de um destes mecanismos. A levedura modelo $S$. cerevisiae apresenta um mecanismo de recombinação homóloga extremamente eficiente, resultando numa freqüência de inserção de genes direcionada elevada (perto dos 100\%) e requer apenas 40 pares de bases de homologia com o gene alvo nas extremidades do cassete de inserção (Baudin et al. 1993). No entanto, S. cerevisiae neste aspecto é uma exceção à regra, uma vez que os fungos filamentosos e organismos eucariotos superiores, apresentam na generalidade um sistema de recombinação homóloga ineficiente. No caso dos fungos filamentosos, por exemplo, a recombinação homóloga ocorre a muito baixa freqüência $(0,1-20 \%)$ e requer a utilização de cassetes com regiões ladeadoras com mais de 2000 pares de base de homologia ao DNA alvo, caso se deseje inserir um fragmento de DNA de forma direcionada . A levedura $K$. lactis, próxima de S. cerevisiae e de K. marxianus, possui um grau intermediário de recombinação homóloga. Geralmente, com fragmentos de DNA possuindo centenas de pares de bases de homologia, a eficiência da integração é mais de 50\%, embora alguns casos tenham sido descritos com integração homóloga em menos de $1 \%$ dos transformantes (Zeeman e Steensma, 2003). A ineficiência do sistema de recombinação homóloga dificulta não só a interrupção de genes, dificultando o estudo fisiológico destes organismos, como também dificulta a integração de cassetes de expressão em locais pré-definidos.

Como referido anteriormente, a integração de cassetes de expressão em múltiplas cópias pode ser conseguida de forma aleatória, mas a integração nãodirecionada poderá afetar aspectos essenciais da fisiologia do hospedeiro. Assim, no contexto do desenvolvimento de um sistema de expressão eficiente para $K$. marxianus, é importante estudar este aspecto com vista ao desenvolvimento de 
vetores que integrem os cassetes de expressão em sítios pré-determinados e que não afetem o normal funcionamento da célula. Outro fator relevante é a eficiência da recombinação homóloga. Kooistra et al. (2004) publicaram uma eficiência de integração direcionada de $0 \%$ quando as zonas ladeadoras do gene da marca de seleção continham apenas 50 pb de homologia ao gene alvo em K. lactis. No caso em que foram usadas regiões homólogas de 600 pb, a eficiência de recombinação homóloga subiu para 88\%. Em contrapartida, Ribeiro et al. (2007) alcançaram apenas 34\% de eficiência de recombinação homóloga em $K$. marxianus, usando regiões homólogas ainda maiores que no caso anterior: 723 e 713 pb.

A estabilidade dos vetores integrativos é geralmente muito alta (as taxas de perda da integração são freqüentemente menores que 1\% por geração (Hensing et al., 1995). Uma desvantagem que pode ser citada quanto às construções integrativas é o seu baixo número de cópias por célula. Uma alternativa descrita por Pecota et al. (2007), que permite a integração do gene de interesse em múltiplas cópias ao genoma de K. marxianus, é o emprego de um cassete de seleção reutilizável. Neste caso, o marcador de seleção auxotrófico URA3 (confere capacidade de crescimento de linhagens ura3 em meios desprovidos de uracila) é envolvido a montante e a jusante por duas repetições do gene hisG de Salmonella, formando o cassete URA3blaster (UB). Esse método também foi usado com sucesso em integrações seqüenciais de genes heterólogos em $S$. cerevisiae (Lee e Da Silva, 1997) e em K. lactis (Wang et al., 2003).

Além de requerer vetores eficientes, a expressão de genes heterólogos também depende do promotor e eventualmente de uma seqüência sinal de secreção que direcione a proteína sintetizada para o meio externo, o que geralmente facilita o processo de purificação da mesma (Fonseca et al., 2008).

Um promotor clássico, utilizado em expressão de genes heterólogos em leveduras, é o PGK (phosphoglycerate kinase) de S. cerevisiae. Esse promotor é constitutivo e provoca alta expressão gênica quando o meio de cultura contém glicose. Em conjunto com o terminador do mesmo gene e a seqüência sinal $k_{1}$ de $K$. lactis, constitui o cassete de expressão do plasmídeo pSPGK1, (Fleer et al., 1991) utilizado neste trabalho.

Já o promotor INU1 de K. marxianus é responsável pelo controle da expressão da enzima inulinase nessa espécie. Este promotor contém uma seqüência prepro que confere a sinalização para a secreção da proteína expressada ao meio 
extracelular. Essa seqüência sinal também já foi aplicada com sucesso na secreção de proteínas heterólogas em S. cerevisiae (Chung et al. 1996), mostrando-se mais eficaz do que a seqüência sinal do fator alfa, cuja utilização se encontra generalizada. Além disso, o promotor INU1 é regulado de acordo com a fonte de carbono existente no meio. Não promove transcrição na presença de lactose e em contrapartida promove a expressão na presença de sacarose. Dados da literatura sobre a síntese heteróloga de proteínas sob controle do promotor e seqüência prepro INU1 demonstram a obtenção de $60 \mathrm{mg} / \mathrm{L}$ de interferon humano $\alpha-2 a$ no meio extracelular (Cai et al., 2005). Outro estudo realizado por Bergkamp et al. (1993) relata a produção e secreção para o meio extracelular de $150 \mathrm{mg} / \mathrm{L}$ de agalactosidase. Neste mesmo estudo também é destacado que a eficiência de secreção da enzima heteróloga sob controle de INU1 alcançou 99\% (o que inclui as frações periplásmica e do sobrenadante).

No presente trabalho, objetivou-se o desenvolvimento de dois vetores epissomais e um integrativo para a expressão separada de dois genes heterólogos: a esterase de Thermus thermophilus e a glicose oxidase (GOX) de Aspergillus niger nas leveduras $K$. marxianus e $K$. lactis. Os promotores utilizados foram o ScPGK ou - KmINU1. A linhagem de K. marxianus selecionada para este estudo foi a CBS 6556, de acordo com estudos fisiológicos prévios, descritos no capítulo 2 desta tese.

\section{Materiais e métodos}

\subsection{Microrganismos}

As diferentes células utilizadas neste trabalho estão listadas na Tabela 3.1. A linhagem $K$. lactis PM5-3C é derivada da CBS 2359, com genótipo apresentado na Tabela 3.1, e foi utilizada como linhagem hospedeira dos genes heterólogos como $K$. lactis CBS 2359 ura-. Já a linhagem K. marxianus SLC33 foi desenvolvida neste trabalho, tendo sido derivada da linhagem $K$. marxianus CBS 6556, possuindo o gene URA3 não funcional. 
Tabela 3.1. Lista das linhagens utilizadas neste trabalho.

\begin{tabular}{|c|c|c|}
\hline Linhagem & Genótipo & Origem \\
\hline E. coli DH10b & $\begin{array}{c}F-m c r A \Delta(m r r-h s d R M S-m c r B C) \\
\varphi 80 d l a c Z \Delta M 15 \Delta l a c X 74 \text { recA1 } \\
\text { endA1 ara } \Delta 139 \Delta(\text { ara, leu }) 7697 \\
\text { galU galK } \lambda \text { - rpsL (StrR) nupG }\end{array}$ & Gifco-BRL-Invitrogen \\
\hline K. marxianus SLC33 & ura3 & Este trabalho \\
\hline K. marxianus CBS 6556 & Wild type & $\begin{array}{l}\text { Centraal Bureau voor } \\
\text { Schimmelcultures }\end{array}$ \\
\hline K. marxianus CBS 397 & Wild type & $\begin{array}{l}\text { Centraal Bureau voor } \\
\text { Schimmelcultures }\end{array}$ \\
\hline K. marxianus CBS 712 & Wild type & $\begin{array}{l}\text { Centraal Bureau voor } \\
\text { Schimmelcultures }\end{array}$ \\
\hline K. lactis PM5-3C & MATa uraA Rag & $\begin{array}{c}\text { Dra. Micheline Wesolowski- } \\
\text { Louvel }\end{array}$ \\
\hline S. cerevisiae BY4742 & $\begin{array}{c}\text { MATa his3D1 leu2D0 lys2Do } \\
\text { ura3D0 }\end{array}$ & Euroscarf \\
\hline
\end{tabular}

\subsection{Meios de cultivo}

A seguir será descrita a composição dos meios de cultivo utilizados para o crescimento de bactérias e leveduras. Os meios líquidos foram preparados em água destilada e os meios sólidos foram suplementados com ágar bacteriológico a 1,5\% para preparo em placas de Petri. A esterilização dos meios foi feita em autoclave durante 20 minutos a $121^{\circ} \mathrm{C}$.

\subsubsection{Yeast extract, tryptone (YT)}

Trata-se se um meio líquido empregado para a indução do estado de competência em bactérias. Sua composição é a seguinte (em $\mathrm{g} \mathrm{L}^{-1}$ ): bacto-triptona (10), extrato de levedura (5) e peptona (5).

3.2.2. Luria-Bertani (LB), Luria-Bertani-Ampicilina (LBA), Luria-Bertani-Ampicilina-XGal (LBA-X-Gal)

É um meio para crescimento de bactérias. Sua composição é a seguinte: (em g L-1): bacto-triptona (10), extrato de levedura (5), cloreto de sódio (5) e glicose (1). Para seleção de bactérias transformadas com o gene de resistência a ampicilina $(a m p R)$, adicionou-se ampicilina a uma concentração final de $40 \mathrm{mg} \mathrm{L}^{-1}$. Esse meio 
suplementado foi denominado Luria-Bertani-Ampicilina (LBA). Também poderia ser adicionado X-Gal e IPTG ao meio LBA à concentração de 40 e 92 mg/L, respectivamente, para seleção de bactérias transformadas pelo sistema branco/azul. Esse último meio foi denominado LBA-X-Gal.

\subsubsection{Yeast extract, peptone, dextrose (YPD)}

Meio complexo usado no crescimento de leveduras. Sua composição (em g $\mathrm{L}^{-1}$ ): glicose (20), extrato de levedura (10) e peptona (20).

\subsubsection{Meio Completo (CM)}

Este meio sintético definido, descrito por Zitomer et al. (1976), foi utilizado na seleção das leveduras transformadas, cuja marca de seleção era a auxotrofia a algum aminoácido. Neste trabalho, o meio CM desprovido de uracila foi denominado CM-URA.

\subsubsection{Placas 5-FOA}

Este meio, descrito por Boeke et al. (1984), foi utilizado na seleção de células que possuíam o gene URA3 inativo. Este gene codifica para a enzima orotidina-5'fosfato decarboxilase (OMP), presente na via biossintética das pirimidinas. Linhagens deficientes neste gene tornam-se resistentes ao composto ácido 5fluorótico (5-FOA).

\subsubsection{Meio YPHSM}

Meio usado nos cultivos de seleção dos transformantes. Desenvolvido para garantir uma maior estabilidade plasmidial. Sua composição foi (em g L-1): glicerol (30), extrato de levedura (10), peptona (80), mais a fonte de carbono (10), que poderia ser glicose (YPHSM-GLC) ou sacarose (YPHSM-SUC). 


\subsection{Oligonucleotídeos}

Os diferentes oligonucleotídeos utilizados neste trabalho, bem como sua função, estão listados na Tabela 3.2.

Tabela 3.2. Lista de oligonucleotídeos utilizados nestes trabalho.

\begin{tabular}{|c|c|}
\hline \multicolumn{2}{|l|}{ Oligonucleotídeos } \\
\hline $\begin{array}{l}\text { Nome } \\
\text { Seqüência }\end{array}$ & Função \\
\hline $\begin{array}{l}\text { KmURA3F } \\
\text { 5'- AGCATCTTGGTCTTCTGAGCT } \\
\text { KmURA3R } \\
\text { 5'- TGTGACGCAATGCCATTACA }\end{array}$ & $\begin{array}{c}\text { Amplificar o gene URA3 de } K \text {. } \\
\text { marxianus CBS6556 }\end{array}$ \\
\hline $\begin{array}{l}\text { PSEST1KF } \\
\text { 5'- GAATTCAGGGCCTCGAGGCCTTCTGG } \\
\text { PSEST1KR } \\
\text { 5'- GAATTCTCAAGGCCGCACCCGGGGGG }\end{array}$ & $\begin{array}{l}\text { Amplificar o gene da esterase } \\
\text { de T. thermophilus para cloná- } \\
\text { lo no plasmídeo pSPGK1 }\end{array}$ \\
\hline $\begin{array}{l}\text { PSPGOXF } \\
\text { 5'- TTTTTGCTGTCATTCGTTCAAGGTAAAAGAAGCAATGGC } \\
\text { ATTGAAGCC }\end{array}$ & $\begin{array}{l}\text { Amplificar o gene GOX do } \\
\text { plasmídeo pBT 86. Possui uma }\end{array}$ \\
\hline $\begin{array}{l}\text { PSPGOXR } \\
\text { 5' - } \text { CACCACCACCAGTAGAGACATGGGAGATCGTCACTGC } \\
\text { ATGGAAGCATA }\end{array}$ & $\begin{array}{l}\text { cauda para recombinação em } \\
\text { pSPGK1 (sublinhado) }\end{array}$ \\
\hline $\begin{array}{l}\text { PINU1Fb } \\
\text { 5'- GGATCCGAATTCTCAAACCGAAATGGG } \\
\text { PINU1Rb } \\
\text { 5'- GGATCCACGCCAGACGTCTTGTGTCCG }\end{array}$ & $\begin{array}{l}\text { Amplificar o cassete INU1 } \\
\text { (promotor + sinal de secreção } \\
+ \text { CDS + terminador) de K. } \\
\text { marxianus CBS6556 }\end{array}$ \\
\hline $\begin{array}{l}\text { PINUESTF } \\
\text { 5' - GTCAGTGCTTCAGTTATCAATTACAAGAGAATGAAGCGG } \\
\text { CTTATCGCG } \\
\text { PINUESTR } \\
\text { 5' - TTTTGTCGTTAGTAAAGTAAGCAGATCAGATCAAGGCCG } \\
\text { CACCCGGGG }\end{array}$ & $\begin{array}{l}\text { Amplificar o gene da esterase } \\
\text { de } T \text {. thermophilus. Possui } \\
\text { cauda de recombinação } \\
\text { (sublinhada) para a seqüência } \\
\text { sinal de secreção (PINUESTF) } \\
\text { e terminador (PINUESTR) do } \\
\text { gene INU1 }\end{array}$ \\
\hline $\begin{array}{l}\text { PINUGOXF } \\
\text { 5' - GTCAGTGCTTCAGTTATCAATTACAAGAGAAGCAATGGC } \\
\text { ATTGAAGCC } \\
\text { PINUGOXR } \\
\text { 5' - TTTTGTCGTTAGTAAAGTAAGCAGATCAGATCACTGCAT } \\
\text { GGAAGCATA }\end{array}$ & $\begin{array}{l}\text { Amplificar o gene da GOX de } \\
\text { A. niger. Possui cauda de } \\
\text { recombinação (sublinhada) } \\
\text { para a seqüência sinal de } \\
\text { secreção (PINUGOXF) e } \\
\text { terminador (PINUGOXR) do } \\
\quad \text { gene INU1 }\end{array}$ \\
\hline
\end{tabular}




\subsection{Vetores}

\subsection{1. pSPGK1}

O vetor epissomal utilizado neste trabalho foi o pSPGK1 (ampr oriC $\mathrm{PGK}_{\mathrm{p}} / \mathrm{PGK}_{\mathrm{T}}$ S11 URA3; Figura 3.1a) cedido por H. Fukuhara (Becerra et al., 2001). É um vetor derivado do pKD1 de Kluyveromyces drosophilarum, o qual possui origem de replicação bacteriana e confere às bactérias resistência à ampicilina como sistema de seleção. A origem de replicação em leveduras é a $\mathbf{S 1 1}$, comprovadamente funcional tanto em $K$. lactis quanto em K. marxianus (Bergkamp et al., 1993). Confere às leveduras auxotróficas em uracila fenótipo ura+, fazendo com que esse seja seu sistema de seleção. Esse plasmídeo contém o promotor da fosfoglicerato-quinase ( $P G K$, de S. cerevisiae). Como sinal de secreção, apresenta o da proteína killer $\left(\mathrm{k}_{1}\right)$ de $K$. lactis, e logo após, in-frame à seqüência sinal, existe um único sítio de clonagem EcoRI, seguido pelo terminador do gene PGK.
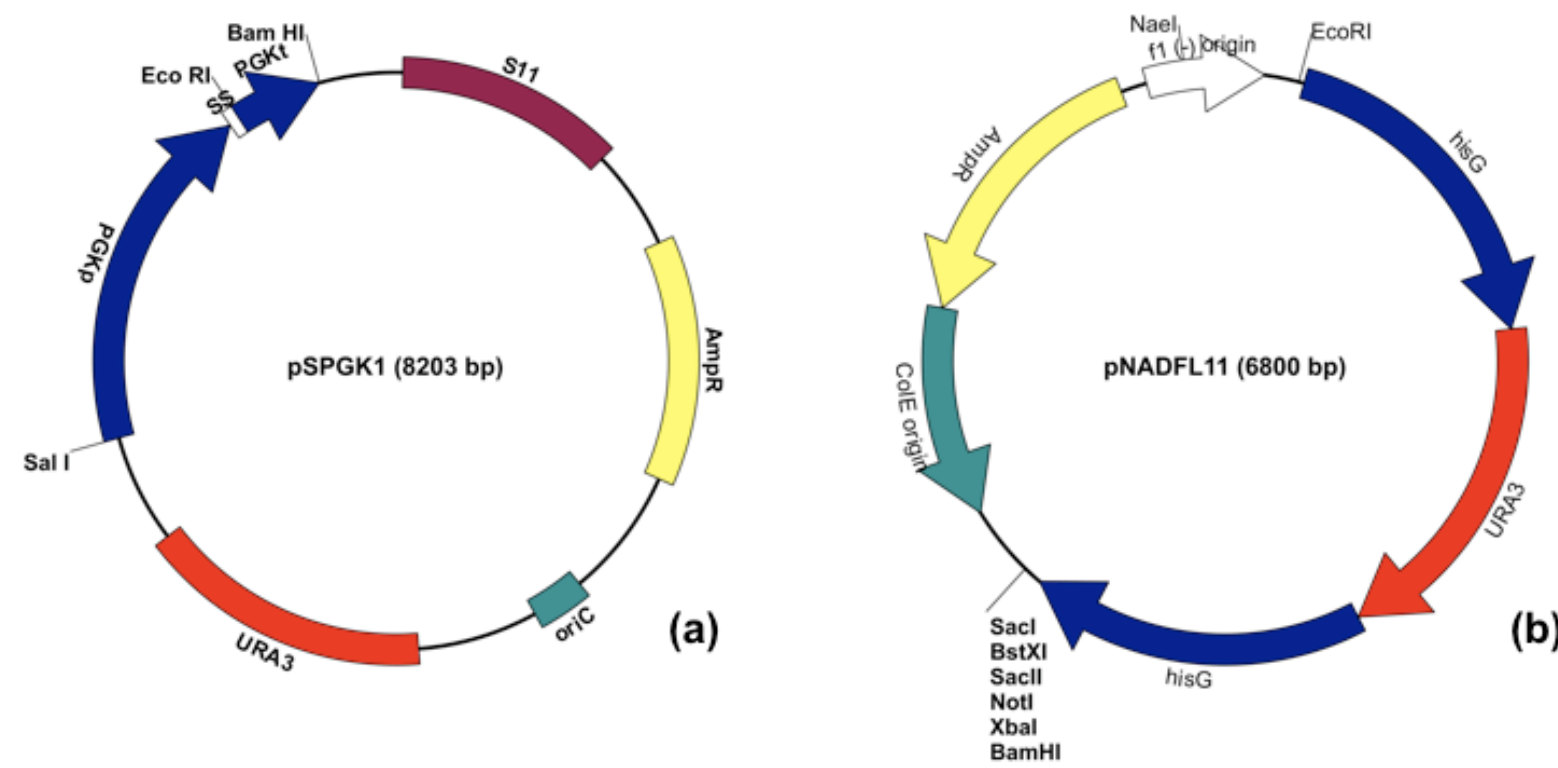

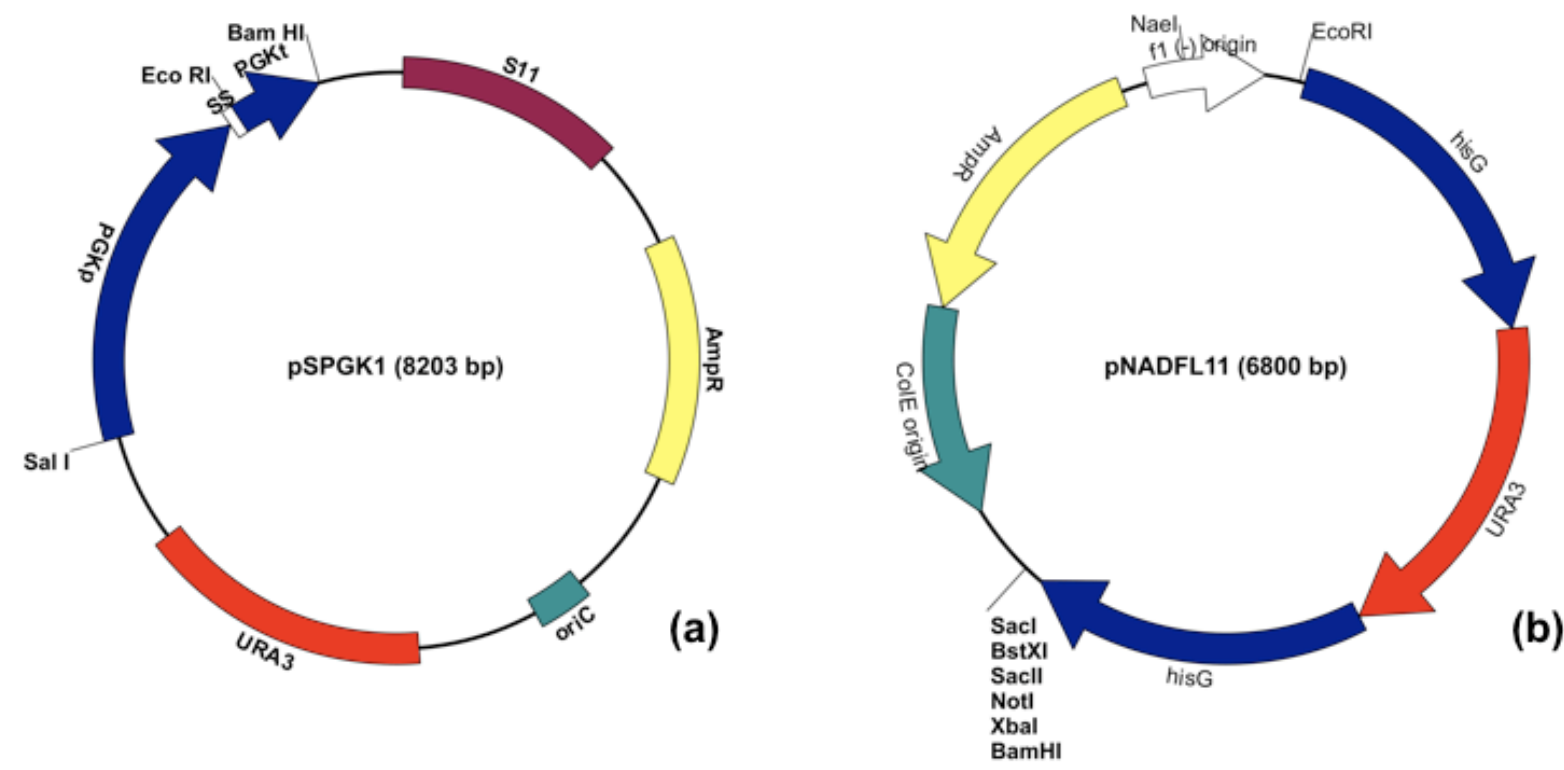

Figura 3.1. Mapas dos plasmídeos (a) pSPGK1 e (b) pNADFL11.

\subsection{2. pNADFL11}

O plasmídeo integrativo pNADFL11 (ampr ColE f1(-) hisG/URA3/hisG; Figura 3.1b) (Pecota et al., 2007) foi gentimente cedido pela Profa. Nancy da Silva, da Universidade da Califórnia em Irvine, EUA. Ele possui como princípio de integração a recombinação do gene URA3 presente no plasmídeo com o do genoma de $K$. marxianus. Possui, à montante e à jusante do gene URA3, seqüências hisG que possibilitam a integração de várias cópias in tandem (Alani et al., 1987). Confere às leveduras auxotróficas em uracila fenótipo ura+, fazendo com que esse seja seu sistema de seleção. Não possui seqüência promotora nem terminador, os quais foram clonados em seu Multiple Cloning Site (MCS) como descrito adiante.

\subsection{3. $\mathrm{pMBL}_{1}-\mathrm{T}$}

Este vetor comercial (Dominon mbl, Espanha; Figura 3.2b) é um sistema utilizado para a clonagem de produtos de PCR amplificados com polimerases que adicionam uma adenina ao extremo 3' da molécula de DNA. 


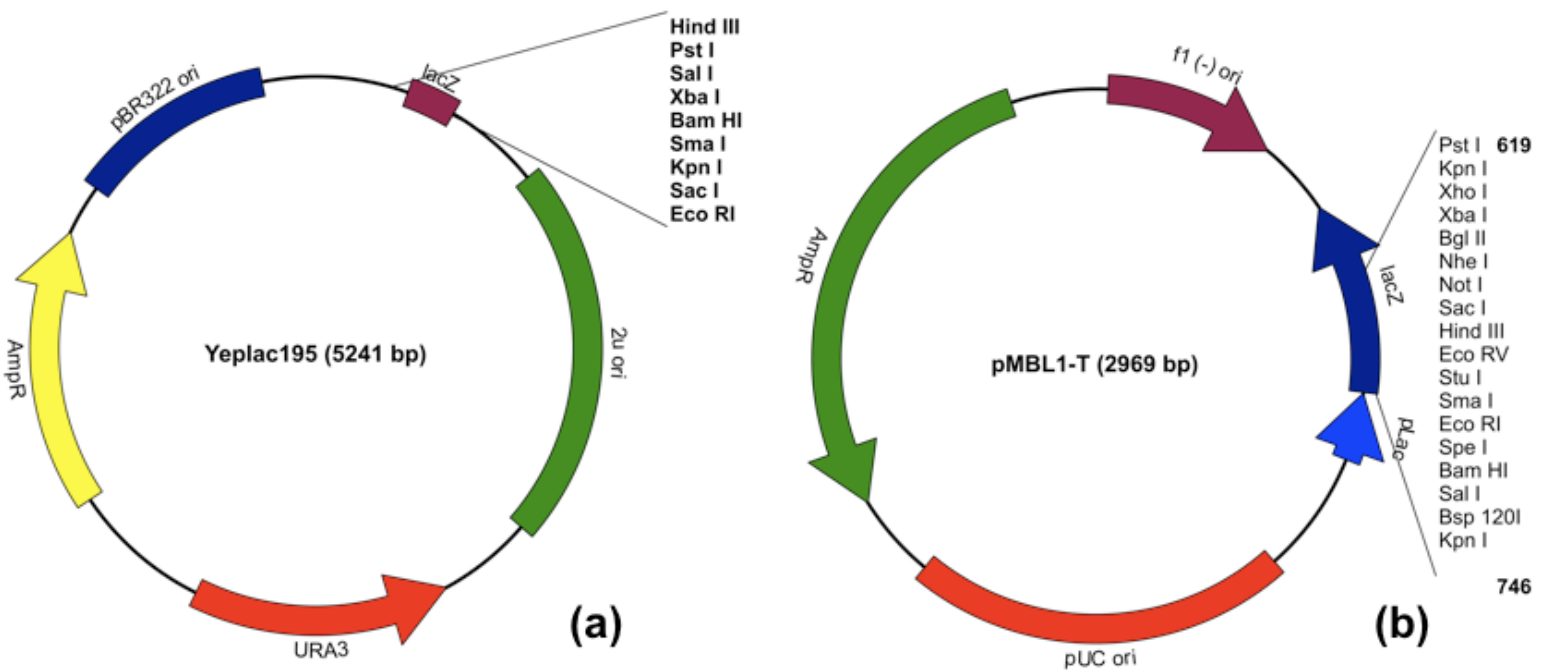

Figura 3.2. Mapas dos plasmídeos (a) Yeplac195 e (b) pMBL1-T.

\subsubsection{Yeplac195}

Este vetor (Figura 3.2a), construído por Gietz e Surgino (1988), foi utilizado para a clonagem do cassete INU1 de K. marxianus e posterior recombinação homóloga dos genes estudados, substituindo a região codificadora da inulinase (INU1) pelas seqüências de interesse. Tal vetor é derivado do $2 \mu$ de $S$. cerevisiae, possuindo portanto origem de replicação para tal levedura. Além disso, possui marcador de seleção para bactérias $\left(A m p^{r}\right)$ e marcador auxotrófico para leveduras (URA3).

\subsection{Técnicas de biologia molecular}

Todos os protocolos de biologia molecular utilizados foram os já publicados no manual escrito por Sambrook e Russell (2001). Em todas as eletroforeses, o marcador de peso molecular utilizado foi o DNA de bacteriófago $\lambda$ digerido pela enzima BstEll (New England Biolabs, EUA), que gerou o padrão de bandas utilizado em todas as eletroforeses. 


\subsection{Obtenção de mutantes nulos ura3 $\Delta$}

Os sistemas de expressão projetados para serem utilizados neste trabalho possuíam o gene URA3 como marcador de seleção. Ou seja, conferiam a capacidade da síntese de uracila em leveduras com deficiência nessa via metabólica, devido à ausência da enzima orotidina-5'-fosfato descarboxilase (OMP), codificada pelo gene URA3. Após transformadas, as células devem ser dispostas em meio seletivo - ausente de uracila - a fim de selecionar somente as células transformadas.

O método utilizado para gerar linhagens ura` foi baseado no descrito por Pecota et al. (2007) que, por sua vez, baseia-se na substituição do gene URA3 funcional por uma seqüência de extremidades homólogas, 162 bases menor, resultando em um gene não funcional.

Para isso, o gene URA3 foi amplificado a partir do DNA cromossomal de Kluyveromyces marxianus CBS 6556 utilizando os primers PURA3F e PURA3R (Tabela 3.2) e, posteriormente, purificado usando sais e etanol. O fragmento foi ligado ao plasmídeo $\mathrm{pMBL}_{1}-\mathrm{T}$, formando o plasmídeo pURA3 (Figura 3.3a). Transformou-se E. coli DH10b. Logo após, o plasmídeo pURA3 sofreu um digestão com a enzima de restrição EcoRV, que apresenta, neste caso, dois sítios de corte distantes 162 pb e relativamente no centro do gene URA3. Purificou-se utilizando kit comercial e o plasmídeo digerido foi submetido a uma reação de autoligamento, formando o novo plasmídeo pURA3A (Figura 3.3b) contendo o gene URA3A.

O fragmento URA3A foi amplificado por PCR preparativa utilizando os mesmos primers anteriores (PURA3F, PURA3R). O DNA foi purificado e utilizado para transformar células de K. marxianus CBS 6556, K. marxianus CBS 397 e K. marxianus CBS 712 pelo método de acetato de lítio. Após a transformação, as células foram passadas a placas contendo meio 5-FOA. Controles negativos (não transformados com o fragmento (URA3A) também foram utilizados em cada transformação.

Para analisar os mutantes, foi extraído o DNA cromossomal e amplificou-se o gene URA3 de cada candidato. A amplificação gera um fragmento de 1469 pb caso 
o gene fosse o selvagem e de $1307 \mathrm{pb}$ caso o fragmento URA3A tivesse sido corretamente integrado. Essa diferença foi checada em géis de eletroforese a uma concentração de agarose de 1,5\% (m/v).
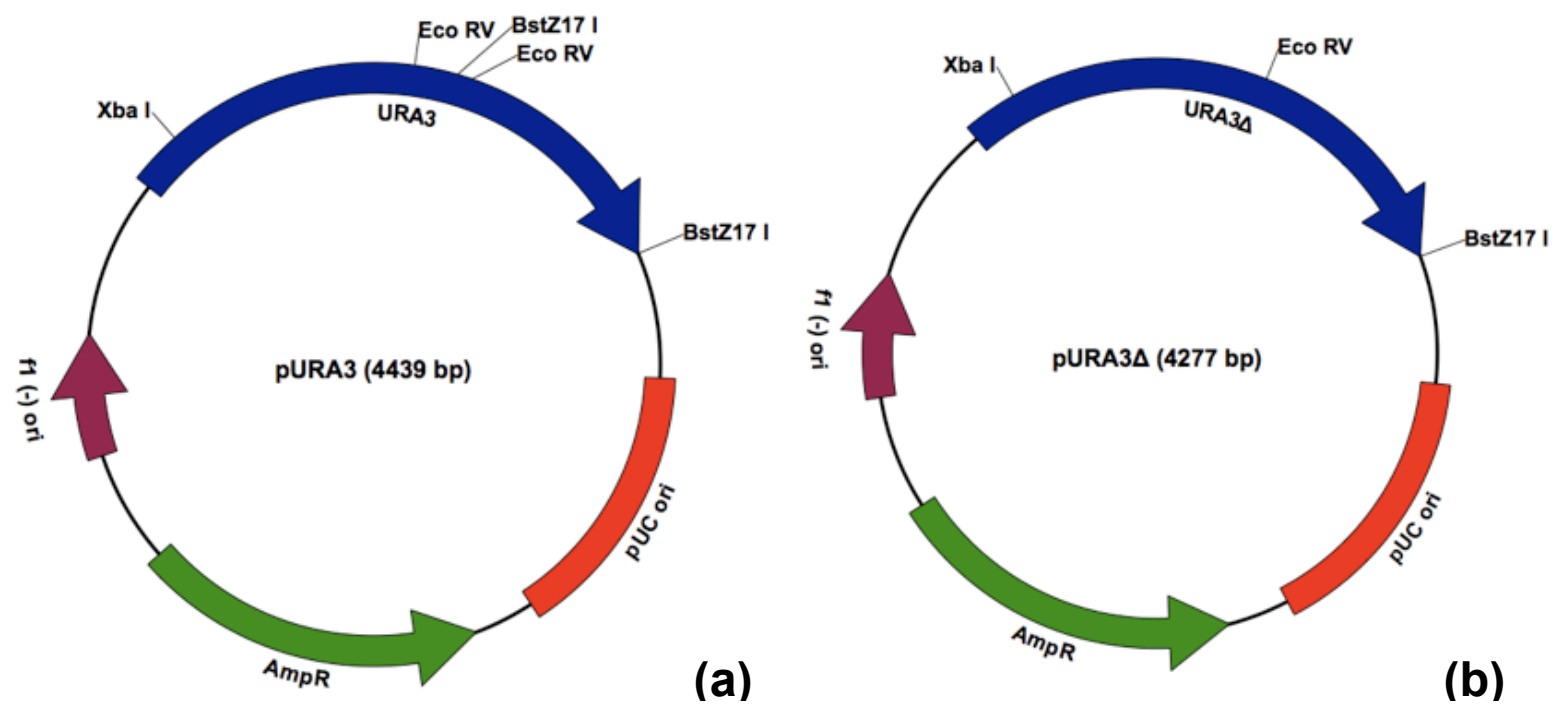

(a)

(b)

Figura 3.3. Mapas dos plasmídeos (a) pURA e (b) pURA3 $\Delta$.

3.7. Estratégias de construção dos vetores de expressão

\subsubsection{Utilizando vetor $\mathrm{pSPGK1}$ e promotor/terminador PGK}

Toda a estratégia está ilustrada na Figura 3.4. Primeiramente, foi realizada a amplificação dos genes que seriam expressos neste sistema. O gene da esterase termófila foi amplificado a partir do DNA cromossomal de Thermus thermophilus HB27 utilizando os primers PSEST1KF e PSEST1KR, os quais possuem nas suas extremidades sítios de restrição para a enzima EcoRI. Da mesma forma, o gene GOX foi amplificado a partir do plasmídeo pBT86 gentilmente cedido por Oscar Bañuelos, Puleva Biotech S.A., Espanha. Neste caso, os primers utilizados para a amplificação da seqüência foram o PSPGOXF e o PSPGOXR, que possuíam uma ponta para recombinação da seqüência codificadora de GOX em pSPGK1. Isso teve que ser feito pois GOX possuía um sítio de restrição para EcoRI.

O produto de PCR da amplificação da esterase foi purificado utilizando sais e etanol e depois ligado ao plasmídeo $\mathrm{pMBL}_{1}-\mathrm{T}$, resultando no plasmídeo $\mathrm{pMBEST}$. 
Essa construção intermediária foi realizada afim de que se fosse possível possuir uma fonte estável dos fragmentos, sem que fosse necessário ser feito uma PCR a cada vez que precisasse manipular cada seqüência. Além disso, tornar-se-ia possível concentrar ainda mais que em uma simples PCR os genes da esterase. Isso facilitaria o ligamento ou recombinação no vetor final (pSPGK1). O sucesso no ligamento foi checado pela digestão do plasmídeo pMBEST com a enzima EcoRI. Em caso da existência da banda relativa ao vetor $(8,0 \mathrm{~kb})$ e ao inserto $(1,0 \mathrm{~kb})$, o candidato era considerado positivo.

Para o próximo passo, partiu-se de 2-5 $\mu \mathrm{g}$ de pMBEST e digeriu-se com Eco RI. Realizou-se uma eletroforese preparativa, retirando a banda relativa à seqüências codificadora da esterase. Purificou-se utilizando kit comercial para purificação de DNA de eletroforese. Em paralelo, digeriu-se pSPGK1 com EcoRI, que em seguida foi purificado com kit comercial de purificação de PCR. Então, a seqüência codificadora da esterase foi ligada ao plasmídeo em reação com a enzima T4 DNA ligase e, após a reação, a mistura foi utilizada para transformar $E$. coli DH10b. Várias colônias eram selecionadas como candidatas a conter a construção correta. Esses candidatos eram crescidos em placas contendo meio LBA por 24h. Após, extraía-se os plasmídeos de cada candidato. Digeriu-se os plasmídeos com a enzima de restrição EcoRI a fim de liberar o fragmento respectivo ao gene da esterase. Caso na eletroforese fossem visualizados tais fragmentos (aproximadamente $1000 \mathrm{pb}$ ), o candidato era considerado positivo e os plasmídeos seriam utilizados para transformar K. marxianus SLC33 e K. lactis PM5-3C (cujos fenótipos são ura-).

No caso da GOX, partiu-se do produto de PCR purificado diretamente para realizar a recombinação homóloga, já que era necessária uma menor concentração de inserto. A recombinação foi realizada em $K$. lactis PM5-3C utilizando mesma proporção de pSPGK1 digerido por Eco RI (purificado) e GOX. A correta recombinação gerou células que expressavam GOX, as quais foram detectadas por top-agar para detecção de atividade de GOX extracelular. Os plasmídeos formados, denominados pSPGOX foram extraídos e inseridos em E. coli DH10b para multiplicação e armazenamento. Então, a recombinação de GOX em pSPGK1 foi confirmada por PCR e o plasmídeo pSPGOX utilizado para transformar $K$. marxianus SLC33. 


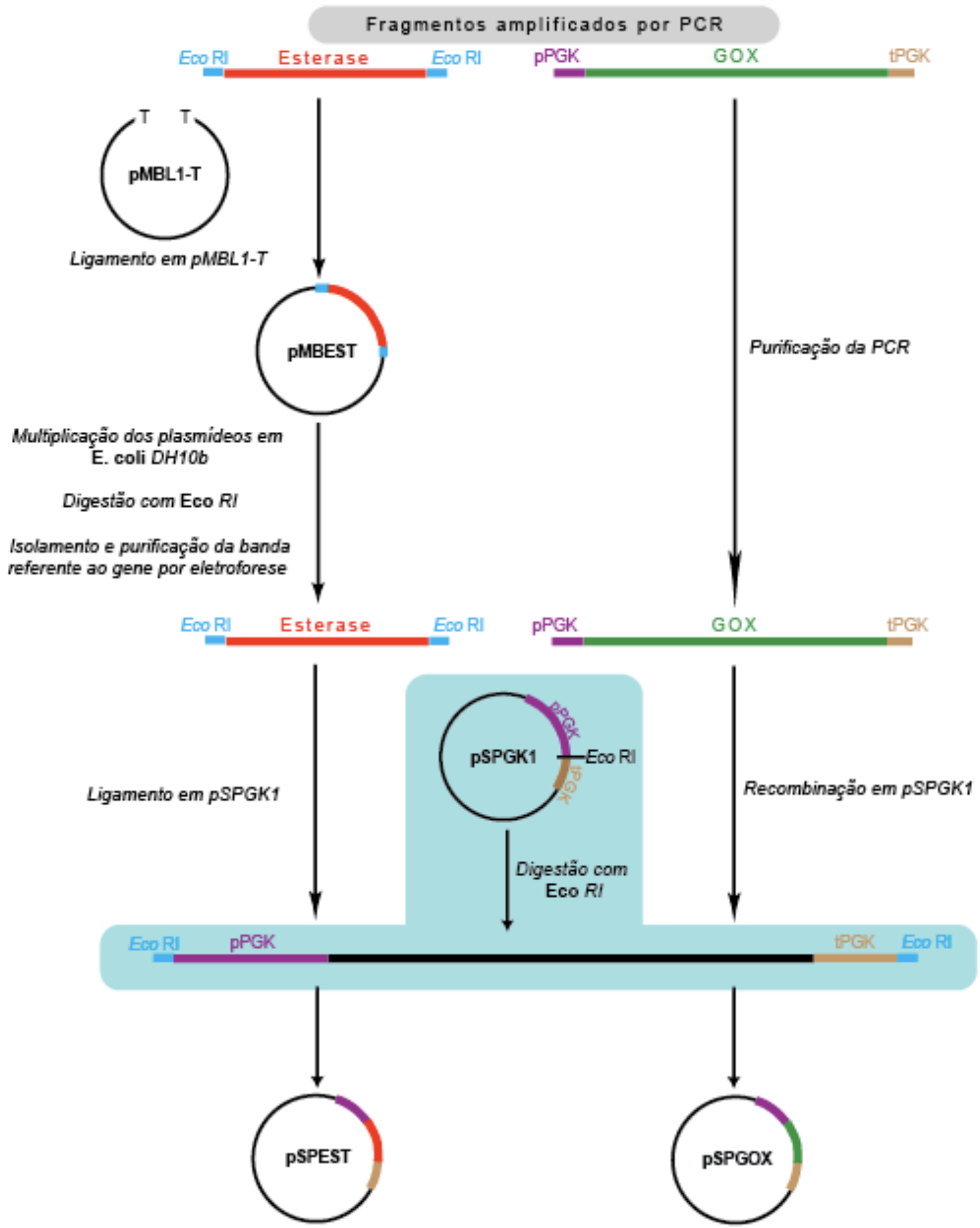

Figura 3.4. Ilustração da estratégia utilizada para a construção dos vetores derivados de pSPGK1. 


\subsubsection{Construção dos cassetes derivados de INU1}

Para construir os cassetes cuja expressão fosse controlada por promotor, seqüência sinal de secreção e terminador do gene da inulinase (INU1) de $K$. marxianus, foi utilizada a estratégia que será descrita a seguir e está ilustrada na Figura 3.5.

Primeiramente, amplificou-se o cassete de expressão do gene INU1 a partir do DNA cromossomal de $K$. marxianus CBS6556 utilizando os primers PINU1Fb e PINU1Rb. Depois de amplificado, o fragmento de $3,4 \mathrm{~kb}$ foi ligado no vetor $p M B L_{1}-T$, obtendo-se o plasmídeo pMBINU. Este plasmídeo foi multiplicado em E. coli DH10b, extraído das bactérias e digerido com $\mathrm{BamHI}$, para liberar o fragmento referente ao cassete. $\mathrm{O}$ plasmídeo pMBINU teve suas partes separadas por eletroforese e a banda relativa a INU1 foi extraída e purificada para ligamento em Yeplac195.

Em paralelo, o plasmídeo Yeplac195 foi também digerido com BamHI e desfosforilado. Em seguida, realizou-se uma reação de ligamento entre o plasmídeo digerido e desfosforilado com o cassete purificado a partir de eletroforese na proporção de 1:5, respectivamente. Dessa reação, transformou-se E.coli DH10b e checou-se os candidatos contendo plasmídeos por digestão com BamHI. Uma vez selecionado um clone contendo o inserto, o novo plasmídeo Yeplac195 contendo o cassete INU1 foi denominado pYINU.

Após a montagem do plasmídeo pYINU, o gene da esterase foi amplificado a partir do DNA cromossomal de $T$. thermophilus HB27 utilizando os primers PINUESTF e PINUESTR. Também foi amplificado o gene GOX a partir do plasmídeo pBT86 utilizando os primers PINUGOXF e PINUGOXR. Ambas amplificações geram fragmentos contendo os genes e também uma ponta adicional de 30 pares de base a montante e a jusante do gene. Essas pontas foram idealizadas para que fossem homólogas à seqüência sinal de INU1 (ponta a montante) e ao terminador de INU1 (ponta a jusante). Dessa forma, uma vez digerido o plasmídeo PYINU na região codificadora do gene INU1, tornaria-se possível a recombinação homóloga de esterase e GOX, substituindo a CDS existente. Além disso, em caso de uma correta recombinação, não se perderia o framing correto do gene recombinado com o promotor INU1, garantindo uma correta expressão dos genes heterólogos a posteriori. Os fragmentos amplificados foram 
purificados utilizando sais e etanol.

O plasmídeo pYINU possui um único sítio de restrição para a enzima Tth111I, justamente na região codificadora da inulinase. Assim, este foi digerido com esta enzima e purificado utilizando kit comercial. Com o vetor linearizado e as seqüências contendo pontas homólogas ao plasmídeo, seguiu-se com a transformação de $S$. cerevisiae BY4742, que foi realizada adicionando iguais proporções de plasmídeo e inserto a recombinar (esterase ou GOX). O método utilizado para a transformação foi o de acetato de lítio.

Uma vez transformadas, as células foram dispostas em meio seletivo CM-URA. Algumas colônias eram selecionadas e cultivadas em meio YPHSM contendo sacarose como fonte de carbono. A presença de atividade para esterase ou GOX indicava a presença da construção. O plasmídeo contendo o cassete de expressão com o gene da esterase termófila foi denominado pYINEST e com o gene da GOX, pYINGOX. Candidatos positivos eram crescidos por $24 \mathrm{~h}$ em meio CM-URA, dos quais se extraíam os plasmídeos. Com a suspensão de plasmídeos, transformaramse E. coli competentes. A presença dos plasmídeos pYINEST e PYINGOX foi confirmada pela extração dos plasmídeos dessas bactérias e posterior digestão com BamHI. Os cassetes construídos foram utilizados para a construção de vetores de expressão derivados de pSPGK1 e pNADFL11, utilizando procedimentos que serão descritos nos ítens 3.7 .3 e 3.7 .4 a seguir. 
Cassete INU1 de K. marxianus amplificado por PCR

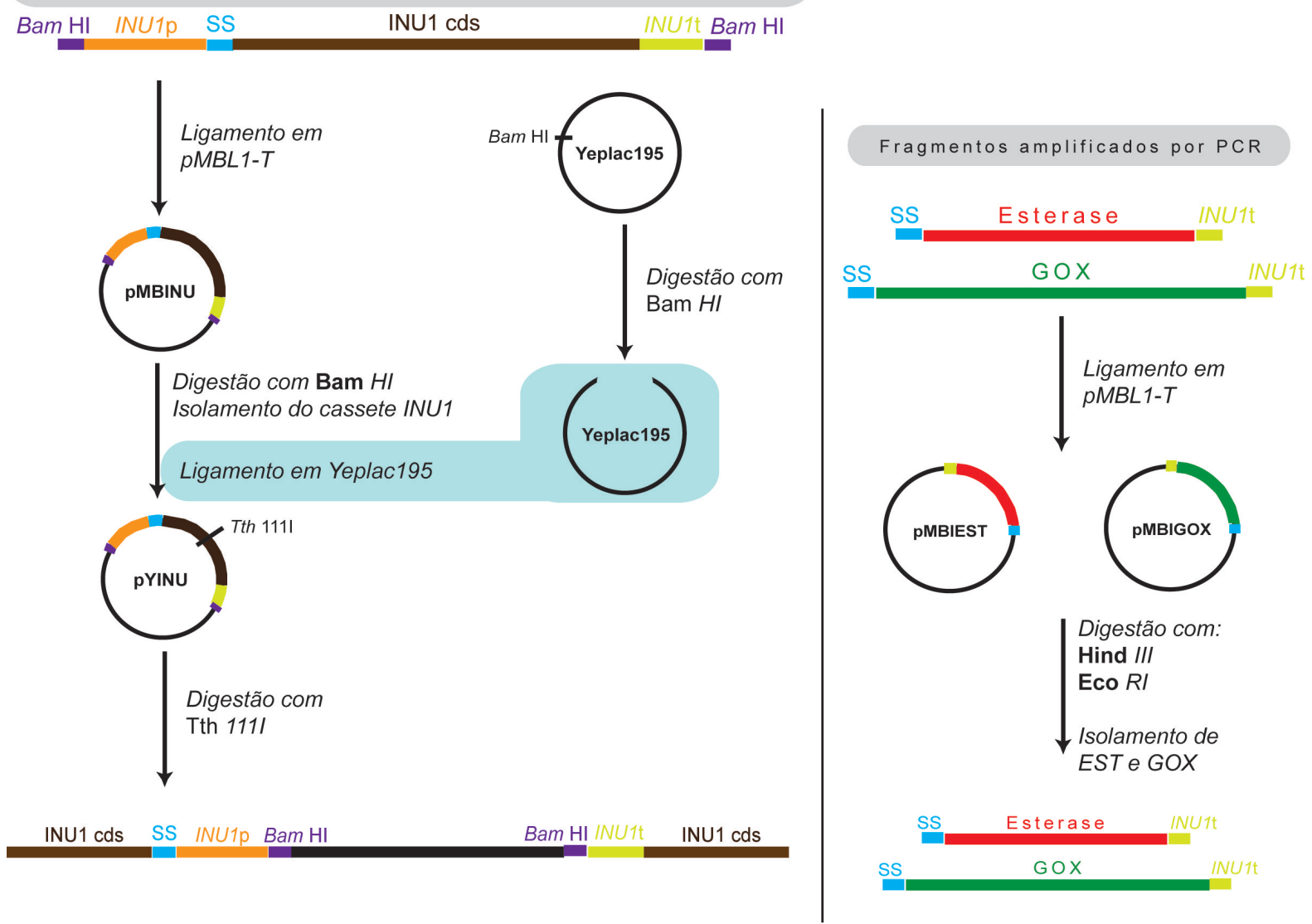

Recombinação dos genes Esterase e GOX com pYINU em S. cerevisiae
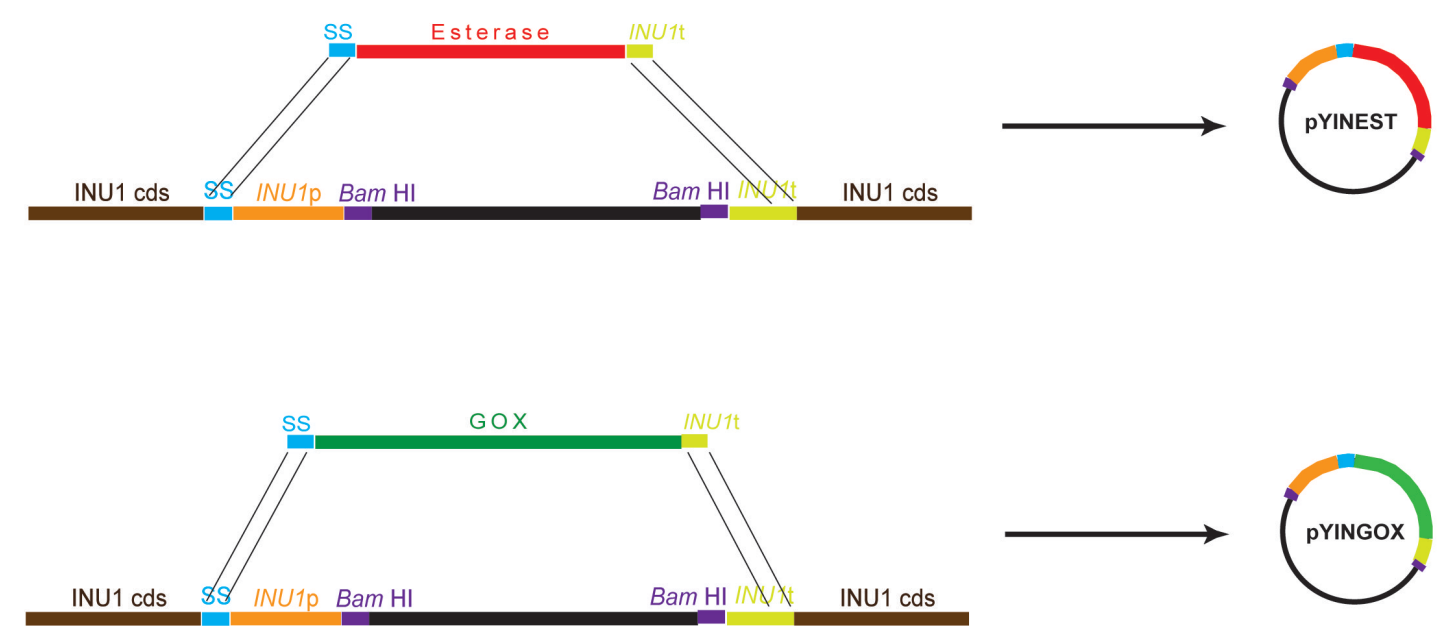

Figura 3.5. Esquema da estratégia de construção dos cassetes de expressão de esterase e GOX sobre o controle de INU1 de K. marxianus. Os tamanhos dos fragmentos estão fora de escala. 


\subsubsection{Utilizando o vetor pNADFL11 e promotor/terminador INU1}

A adição dos cassetes de expressão derivados de INU1 ao vetor pNADFL11 foi feita por ligamento. Os cassetes foram retirados dos plasmídeos pYINEST e pYINGOX por restrição com BamHI. Logo após, os fragmentos formados foram separados por eletroforese e a banda relativa aos cassetes contendo esterase e GOX foram purificados utilizando kit comercial para purificação de DNA de eletroforese. Paralelamente, o plasmídeo pNADFL11 também foi digerido com BamHI e em seguida desfosforilado, para evitar auto-ligamento. Plasmídeo (pNADFL11) e insertos (esterase ou GOX) foram submetidos a uma reação de ligamento na proporção de 1:5. Logo após, transformou-se bactérias competentes $E$. coli DH10b e confirmou-se o sucesso de cada construção com a digestão dos plasmídeos com BamHI.

Logo a seguir, os plasmídeos formados foram digeridos com Nael e Sacll a fim de linearizá-los para a integração e retirar um fragmento dispensável na expressão dos genes heterólogos das leveduras. Foram transformadas as espécies $K$. lactis PM5-3C e K. marxianus SLC33. A primeira foi transformada usando o método de acetato de lítio. Já a segunda, devido ao insucesso após três tentativas de se obter mutantes utilizando a técnica de transformação química, foi transformada por eletroporação. As colônias mutantes foram selecionadas utilizando top-agar. As que apresentaram maior intensidade de halo de atividade enzimática foram selecionadas para um teste comparativo entre os candidatos em cultivo líquido.

\subsubsection{Utilizando o vetor PSPGK1 e promotor/terminador INU1}

Os cassetes derivados de INU1 que contêm os genes de esterase e GOX também foram ligados ao plasmídeo pSPGK1 para que fosse criado um sistema de expressão epissomal sob controle do referido promotor. Para isso, foi aproveitado o único sítio de restrição $B a m H I$ que este plasmídeo contém para ligar todo o cassete de expressão. 
O plasmídeo pSPGK1 foi digerido com Bam $\mathrm{HI}$, purificado utilizando kit comercial, desfosforilado e em seguida, novamente purificado. Em paralelo, os cassetes de expressão contidos nos plasmídeos pYINEST e pYINGOX foram sacados dos respectivos vetores por restrição usando Bam $\mathrm{HI}$ e separados por eletroforese. As bandas relativas às seqüências de expressão foram extraídas do gel de eletroforese e purificadas. Preparados, vetor e insertos (esterase e GOX) foram submetidos a uma reação de ligamento, sendo que a proporção entre vetor e inserto em cada reação foi de 1:10. As colônias transformantes foram selecionadas inicialmente utilizando-se a técnica de top-agar para determinação de atividade enzimática. Os candidatos positivos quanto à atividade de esterase ou GOX foram, logo após, submetidos a uma seleção em meio líquido para verificar o melhor candidato que fosse capaz de expressar cada uma das duas enzimas.

\subsection{Determinação da atividade da esterase termófila}

\subsubsection{De amostras líquidas}

A atividade lipolítica da esterase de Thermus thermophilus foi determinada espectrofotometricamente seguindo a liberação dos produtos da hidrólise do laurato de p-nitrofenil conforme descrito por Fuciños et al. (2005).

Para isso, é preparada uma solução de laurato de p-nitrofenil em etanol à concentração de $50 \mathrm{mM}$. Em seguida, em um microtubo são dispostos $800 \mu \mathrm{de}$ tampão Tris- $\mathrm{HCl} 50 \mathrm{mM}\left(\mathrm{pH} \mathrm{8,0} \mathrm{a} 65^{\circ} \mathrm{C}\right.$ ) com $\mathrm{CaCl}_{2} 40 \mathrm{mM}$ e $100 \mu \mathrm{l}$ da solução de substrato. Mistura-se por inversão. Incuba-se a mistura em um banho termostatizado a $65^{\circ} \mathrm{C}$ a fim de estabilizar a temperatura da reação. Passados os dez minutos, adiciona-se $100 \mu \mathrm{l}$ da amostra, misturando com a ponta da pipeta rapidamente. Incuba-se por 20 minutos.

Pára-se a reação inativando a enzima com a adição de $250 \mu \mathrm{l}$ de $\mathrm{Na}_{2} \mathrm{CO}_{3} 1 \mathrm{M}$, mantido em um banho de gelo com agitação suave para que não se precipite. Os tubos são passados a um banho de gelo e mantidos por 15 minutos e, a seguir, sofrem centrifugação por 10 minutos a 13000 x g, para eliminar o precipitado formado. No sobrenadante, determina-se a absorbância a $400 \mathrm{~nm}$ contra um branco. 
O branco deve ser feito a partir de uma amostra de mesma cor que as amostras estudadas. Nessas condições, o coeficiente de extinção molar $(\varepsilon)$ do p-nitrofenolato (produto da reação) é de $17,215 \mathrm{mM}^{-1} \mathrm{~cm}^{-1}$. Define-se uma unidade de atividade de esterase termófila $(1 \mathrm{U})$ como a quantidade de enzima que libera $1 \mu \mathrm{mol}$ de produto p-nitrofenolato por 1 minuto de reação.

\subsubsection{Em placas de Petri (top-agar)}

Este método, desenvolvido neste trabalho, consiste em detectar colônias de células com atividade de esterase, pela hidrólise do laurato de p-nitrofenil contido em uma matriz de agarose. Na presença dessa enzima, a região da colônia torna-se amarelada. A intensidade da cor amarela está relacionada com a atividade da enzima presente.

Primeiramente, as células eram cultivadas em meio CM-URA contendo glicose como fonte de carbono no caso dos plasmídeos derivados de pSPGK1, sob controle do promotor PGK; e sacarose, nos casos em que as construções eram reguladas pelo promotor INU1. Antes de cobrir as placas-problema com agarose contendo os elementos de determinação de atividade enzimática, as mesmas eram replicadas. A seguir era efetuado o método, que consistiu no seguinte. Adicionou-se 0,1 g de agarose a $9 \mathrm{~mL}$ de tampão Tris-HCl $50 \mathrm{mM}$ com acetato de sódio $40 \mathrm{mM}$, pH 8 a $65^{\circ} \mathrm{C}$. A mistura foi levada à fervura em microondas. Logo após, resfriou-se até a temperatura de $50^{\circ} \mathrm{C}$, ponto no qual adicionou-se $1 \mathrm{~mL}$ de uma solução de laurato de $p$-nitrofenil em etanol a $25 \mathrm{mM}$. Imediatamente, dispô-se a agarose e seus componentes sobre uma placa de Petri contendo as colônias que seriam selecionadas. Aguardou-se a solidificação do polissacarídeo e a placa foi selada e levada a um banho a $65^{\circ} \mathrm{C}$ por 20 minutos. Após este tempo, as colônias que apresentavam coloração amarelada (detectada a olho nu) eram marcadas e seus clones eram separados a partir da placa de réplica. 


\subsection{Determinação da atividade da glicose oxidase}

\subsubsection{De amostras líquidas}

O método para a medição da atividade da enzima glicose oxidase (GOX) foi realizado conforme descrito por Malherbe et al. (2003), baseado na transferência de elétrons do $\mathrm{H}_{2} \mathrm{O}_{2}$ (formado a partir da oxidação da glicose pela GOX) para um composto que, quando reduzido, muda de cor (di-hidrocloreto de o-dianisidina).

Em cada tubo de amostra, foram adicionados $500 \mu \mathrm{l}$ de tampão citrato-fosfato $\mathrm{pH} 4,5,1 \mathrm{M} ; 100 \mu \mathrm{l}$ de glicose $1 \mathrm{M} ; 33 \mu \mathrm{l}$ de peroxidase de Armoracia rusticana $60 \mathrm{U} / \mathrm{mL}$; e $333 \mu \mathrm{l}$ de di-hidrocloreto de o-dianisidina $0,31 \mathrm{mM}$. Misturou-se por inversão e incubou-se por 10 minutos a $37^{\circ} \mathrm{C}$. Adicionou-se $10 \mu \mathrm{l}$ de amostra. Incubou-se por 30 minutos a $37^{\circ} \mathrm{C}$ e logo após, parou-se a reação em gelo, adicionando $100 \mu \mathrm{l}$ de $\mathrm{H}_{2} \mathrm{SO}_{4}$. A absorbância foi medida a $500 \mathrm{~nm}\left(\mathrm{~A}_{500}\right)$ e as unidades de glicose oxidase por $\mathrm{mL}$ produzidas eram determinadas em relação a uma curva padrão de $A_{500}$ versus quantidade de enzima (GOX de A. niger, Sigma, EUA). Uma unidade de atividade de glicose oxidase é a quantidade de enzima necessária para oxidar $1 \mu \mathrm{mol}$ de glicose por minuto.

\subsubsection{Em placas de Petri (top-agar)}

Este método foi baseado no descrito por Malherbe et al. (2003) e, assim como o método de detecção de atividade de esterase, baseia-se no mesmo conjunto de reações que ocorrem quando é determinada a atividade de GOX em meio líquido, sendo que neste caso, ao invés de medir a absorbância relativa à redução do dihidrocloreto de o-dianisidina, a cor escura formada por essa reação era observada em halos que se formavam ao redor das colônias as quais apresentavam atividade de GOX extracelular.

As linhagens que possuíam os genes heterólogos sob controle do promotor PGK foram cultivadas por 48 horas em meio CM-URA contendo glicose como fonte de carbono. Por sua vez, as células que continham construções sob controle do 
promotor INU1, foram cultivadas sob as mesmas condições, porém contendo sacarose como fonte de carbono. As placas eram então cobertas com tampão citrato-fosfato (tampão de Mcllvane) 0,1 M, pH 7,0 contendo agarose $1 \%(\mathrm{p} / \mathrm{v}$ ); glicose $10 \mathrm{~g} / \mathrm{L}$; hidrocloreto de o-dianisidina $100 \mathrm{mg} / \mathrm{L}$; e $15 \mathrm{U} / \mathrm{mL}$ de peroxidase tipo II de Armoracia rusticana.

\section{Resultados e Discussão}

Nesta etapa do trabalho, objetivou-se a construção de leveduras capazes de expressar as enzimas esterase de Thermus thermophilus e glicose oxidase de Aspergillus niger. Para isso, foi necessário primeiramente obter mutantes de $K$. marxianus CBS 6556 com o gene URA3 inativo, já que as marcas de seleção utilizadas em todos os plasmídeos seriam o tal gene. Ao todo, foram realizadas construções epissomais e integrativas com os dois genes, utilizando dois conjuntos de promotor, sinal de secreção e terminador diferentes e duas espécies de leveduras (K. marxianus e K. lactis)

\subsection{Obtenção de uma linhagem de K. marxianus auxotrófica para uracila}

Como os marcadores de seleção dos sistemas de expressão construídos funcionam por complementação sobre a auxotrofia em uracila, foi necessário, primeiramente, obter linhagens K. marxianus CBS 6556 ura3. Não foi necessário obter uma nova linhagem $K$. lactis CBS 2359 deficiente na síntese de uracila, pois ela já se encontrava no laboratório sob a denominação de K. lactis PM5-3C. Para tal tarefa, conforme descrito no item 3.6, o gene URA3 de K. marxianus CBS 6556 (1469 pb) foi amplificado, um fragmento de 162 pb da seqüência codificadora foi retirado, e após o religamento, obteve-se uma seqüência de 1307 pb com extremidades homólogas a URA3 (URA3A).

A transformação de K. marxianus CBS 6556, CBS 712 e CBS 397 com o fragmento URA3 $\Delta$ amplificado a partir de pURA3 $\Delta$ foi tentada 5 vezes pelo método de acetato de lítio. Um controle sem transformar foi sempre semeado em outra placa 
5-FOA a cada transformação.

A linhagem K. marxianus CBS 6556 apresentou em média 30 mutantes por placa tanto de transformantes quanto de controle a cada tentativa. Foram analisadas a ocorrência da recombinação em 12 colônias da placa de transformantes de cada tentativa, totalizando 60 candidatos testados. Nenhum apresentou o inserto recombinado. Todos os candidatos possuíam modificações pontuais no gene URA3, de forma que esses mutantes possuíam a capacidade de crescer em meio contendo 5-FOA e não apresentavam crescimento em meio CM-URA. Isso poderia sugerir uma baixa eficiência na recombinação homóloga em $K$. marxianus ou também uma baixa eficiência do método de transformação com acetato de lítio.

Levando-se em consideração o método químico utilizado para transformar as leveduras, poder-se-ia questionar a sua eficiência neste caso. Pecota et al. (2007) realizaram o mesmo procedimento de recombinação do mesmo cassete URA3 $\Delta$ em K. marxianus KM1 pelo método de eletroporação e relataram que houve grande discrepância entre o número de colônias formadas na placa de transformantes e na placa controle. E de fato, confirmaram a interrupção do gene URA3 em alguns candidatos testados. Além disso, posteriormente, neste trabalho, foi verificado que as construções integrativas só transformaram eficientemente $K$. marxianus SLC33 (mutante ura3 pontual) quando empregado o método de eletroporação em detrimento do método de acetato de lítio. Com isso, após tantos fatores indicando que o problema da não obtenção de mutantes por interrupção poderia ser o método de transformação, a eletroporação utilizando o cassete URA3 foi tentada, porém não se obteve sucesso. Coincidentemente, nas duas placas (transformantes e controle) cresceram 8 colônias com o gene URA3 não funcional, porém nenhuma apresentou o gene substituído pelo fragmento URA3 $\Delta$. Não se descarta que o método de transformação influenciou na eficiência da transformação, até pelo fato observado na integração dos genes da esterase e GOX posteriormente descritos, porém o insucesso desta técnica pode ter sido causado também pela baixa eficiência de K. marxianus para efetuar recombinação homóloga.

Essa ineficiência em K. marxianus já foi discutida por Ribeiro et al. (2007). Neste caso, foi alcançada uma eficiência de rompimento do gene $L A C 4$ de $34 \%$ por recombinação homóloga utilizando um sistema Cre-loxP contendo 723 e 713 bases 
ladeando o gene da marca de seleção. Essa eficiência já é muito menor que a relatada em K. lactis, de 88\%, utilizando 600 pares de bases homólogas (Kooistra et al., 2004). Em nosso caso, o fragmento URA3 $\Delta$ possuía 735 e 570 pares de bases homólogas, inferior ao número de bases homólogas usadas por Ribeiro et al. (2007), o que reduz a eficiência da recombinação homóloga. Além disso, não existe informação disponível sobre a ploidia em K. marxianus. Ribeiro et al. (2007), em seus estudos, levantaram a possibilidade de que esta espécie seja diplóide. Esse fato dificultaria a deleção do gene URA3. Por outro lado, Pecota et al. (2007) relataram o sucesso da mesma técnica utilizada neste caso para a deleção de URA3 de K. marxianus, porém, a linhagem utilizada naquele caso (KM1) era diferente da usada neste estudo (CBS 6556), o que pode justificar a diferença na eficiência do método.

Contudo, foram obtidos mutantes K. marxianus CBS 6556 ura3 pontuais. Um desses mutantes foi selecionado ao acaso e crescido em bateladas sucessivas por 120 gerações em meio não seletivo (YPD). Nenhuma reversão da mutação foi observada durante esse período. Com isso, esse candidato foi utilizado em todo o estudo como K. marxianus CBS 6556 ura3 e foi denominado K. marxianus SLC33. Em todos os controles negativos realizados posteriormente, a cada transformação, não foi observada reversão da mutação.

Nos casos de K. marxianus CBS 397 e CBS 712, não foi obtido nenhum mutante com o gene URA3 inativo por nenhuma das duas técnicas: deleção com fragmento homólogo modificado de URA3 ou seleção em meio com 5-FOA. A falta de transformantes, somado ao fato de que essas duas linhagens não foram selecionadas como as com melhor potencial para a produção de proteínas heterólogas no trabalho descrito no capítulo 2, fizeram com que os estudos de transformação de $K$. marxianus fossem realizados apenas com a linhagem SLC33.

\subsection{Construção de $p S P E S T$ e $p S P G O X$ e transformação das leveduras}

Os vetores derivados de pSPGK1 contendo o gene da esterase termófila de $T$. thermophilus (pSPEST) e glicose oxidase de $A$. niger (pSPGOX) foram construídos conforme descritos na seção 3.7 e a confirmação da presença dos 
genes no vetor foi realizada por digestão com EcoRI (no caso do pSPEST) e por PCR utilizando os primers PSPGOXF e PSPGOXR (no caso de pSPGOX). Ambas confirmações estão mostradas na Figura 3.6.
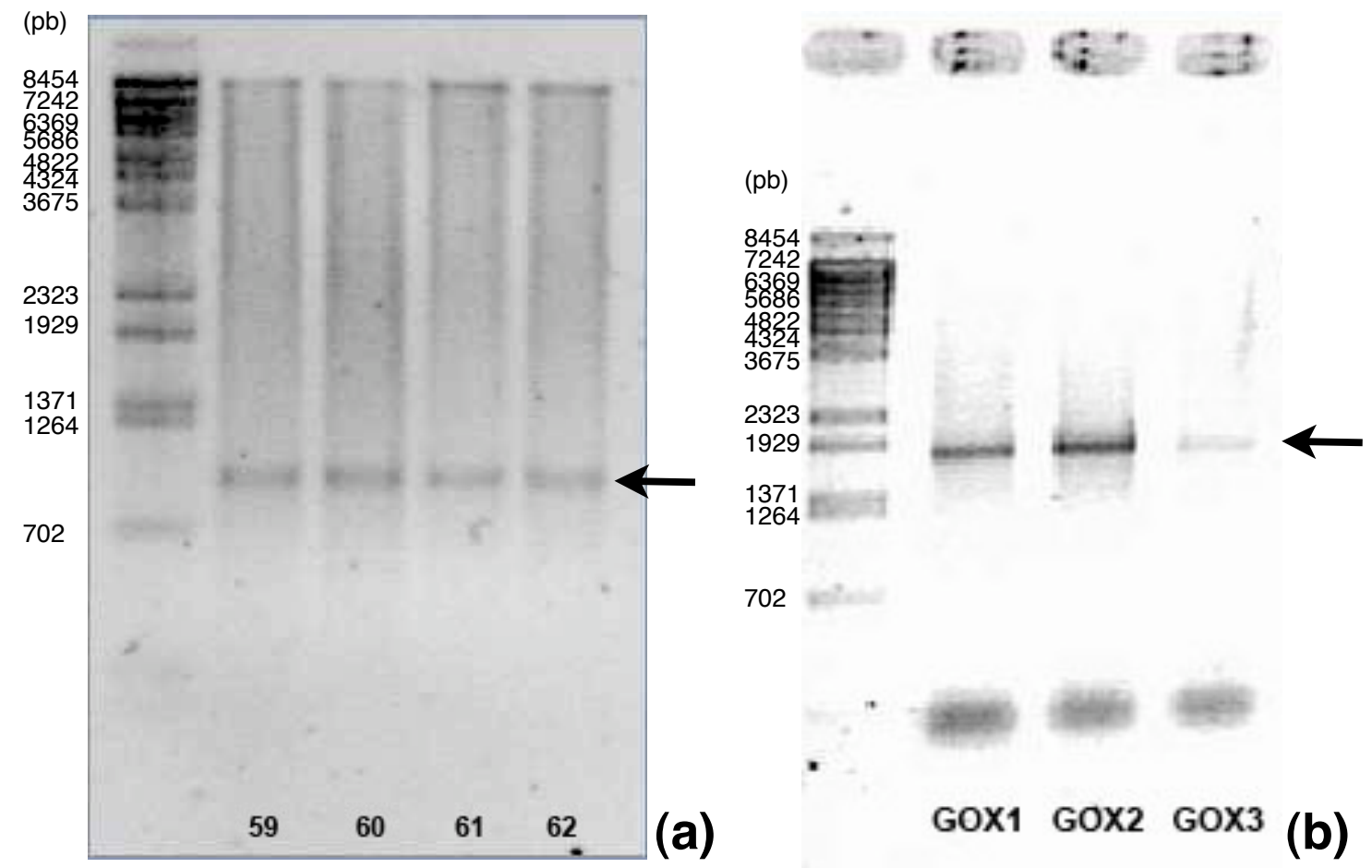

Figura 3.6. Confirmação da construção (a) pSPEST - pela separação por digestão da banda de $1 \mathrm{~kb}$ (seta) do vetor de $8 \mathrm{~kb}$ nos candidatos 59 a 62; e (b) pSPGOX - pela amplificação do gene GOX $(1,8 \mathrm{~kb}$, mostrado pela seta) nos três candidatos testados.

A transformação das leveduras $K$. marxianus SLC 33 e K. lactis PM5-3C com o gene da esterase, contido no plasmídeo pSPEST gerou 22 colônias transformantes no primeiro caso e 31 colônias no segundo. Esse dado não pode ser utilizado como comparativo de eficiência de transformação, já que a concentração de células utilizadas para a inserção de DNA heterólogo, apesar de controlada pela medida de absorbância antes da transformação, não era rigorosamente igual, já que era possível usar cultivos em que a $\mathrm{DO}_{600}$ da suspensão celular variava entre 0,6 e 1,0. Essas colônias foram selecionadas por top-agar com laurato de p-nitrofenilo (ver em materiais e métodos, item 3.8.1). Foram selecionadas 3 colônias de cada linhagem que apresentaram maior intensidade da cor amarela (indicadora da atividade de esterase).

Apesar de existir a linhagem $K$. marxianus CBS 1553, relatada como produtora de esterases (Monti et al., 2008), tanto a linhagem K. marxianus SLC 33 
quanto a K. lactis PM5-3C não apresentaram atividade detectável tanto em placas quanto em cultivo líquido, não interferindo nos dados de atividade obtidos pelas linhagens transformadas.

No caso da construção pSPGOX, a recombinação foi realizada diretamente na levedura $K$. lactis PM5-3C. Com isso, cresceram 12 colônias transformadas que foram testadas quanto à capacidade de expressão de GOX. As três linhagens que apresentaram maior intensidade do halo de atividade foram selecionadas para realização do estudo comparativo de atividade dos candidatos em meio líquido. $A$ linhagem $K$. marxianus SLC 33 foi transformada com os plasmídeos extraídos de $K$. lactis PM5-3C e multiplicados em E. coli DH10b. Ao todo foram 19 colônias das quais, levadas ao teste com top-agar, foram selecionadas as três que apresentavam maior halo de atividade.

\subsection{Construção de pINESTi e pINGOXi e transformação do hospedeiro}

Conforme descrito na seção 3.7.2, a montagem dos vetores de expressão pINESTi e pINGOXi iniciou-se pela amplificação do cassete de expressão INU1 de K. marxianus CBS6556. Em seguida, esse cassete foi ligado ao plasmídeo Yeplac195, formando o vetor pYINU. A partir deste último vetor digerido com Tth 111I, os genes da esterase e GOX foram recombinados para formar os plasmídeos pYINEST e pYINGOX. A correta construção foi confirmada por atividade enzimática extracelular de células de S. cerevisiae BY4742 e por digestão com BamHI, conforme está mostrado na Figura 3.7. 


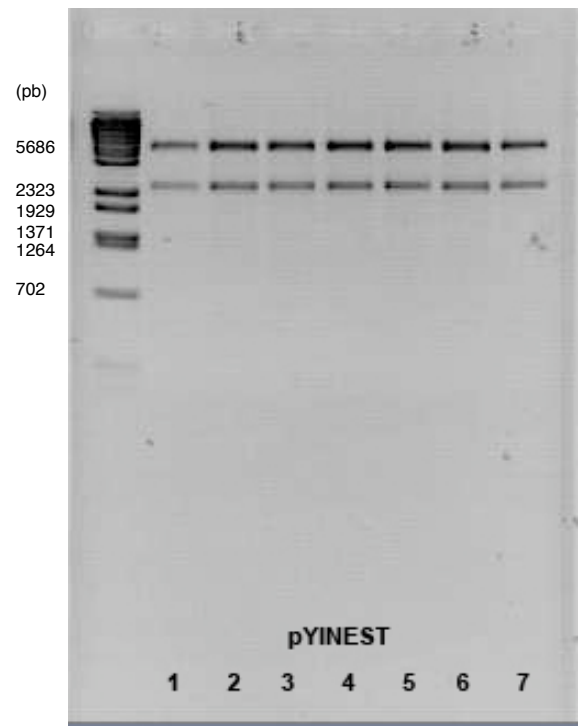

(a)

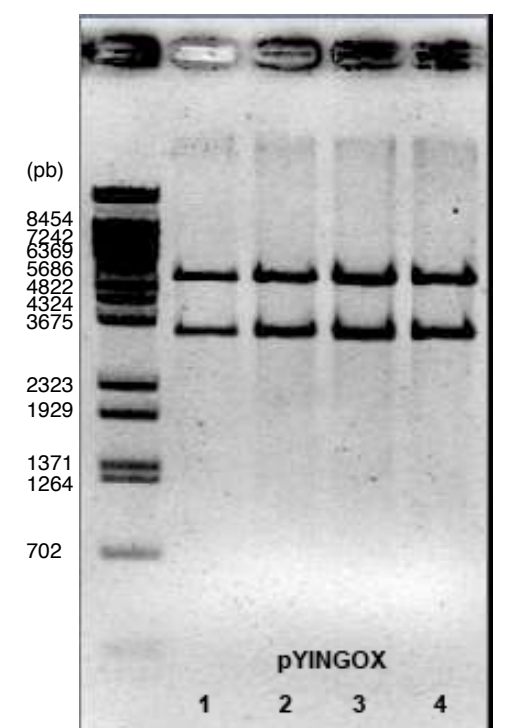

(b)

Figura 3.7. Confirmação por digestão com BamHI da recombinação de (a) EST (b) GOX (banda inferior em todos os candidatos) entre a seqüência sinal de secreção e o terminador INU1 de $K$. marxianus. As bandas de 2,6 kb (EST) e 3,4 kb (GOX) confirmam a substituição da CDS (seqüência codificadora) do gene da inulinase pela CDS do gene da esterase e GOX, além da confirmação por atividade enzimática extracelular.

A seguir, partiu-se para o ligamento do cassete de expressão de esterase e GOX sob controle do promotor/terminador INU1 (INEST e INGOX) ao plasmídeo integrativo pNADFL11. O ligamento foi realizado a uma proporção de plasmídeo defosforilado:inserto de 1:10. Após transformadas as células de $E$. coli, 16 candidatos foram testados quanto a existência de um correto ligamento. A comprovação foi realizada por digestão com a enzima BamHI, a qual liberaria o fragmento INEST $(2,6 \mathrm{~kb})$ ou INGOX $(3,4 \mathrm{~kb})$. Os candidatos que continham o inserto estão mostrados na Figura 3.8a (EST) e 3.8b (GOX). Os novos plasmídeos e objetivos finais dessa seqüência de construções foram denominados pINESTi e pINGOXi, respectivamente.
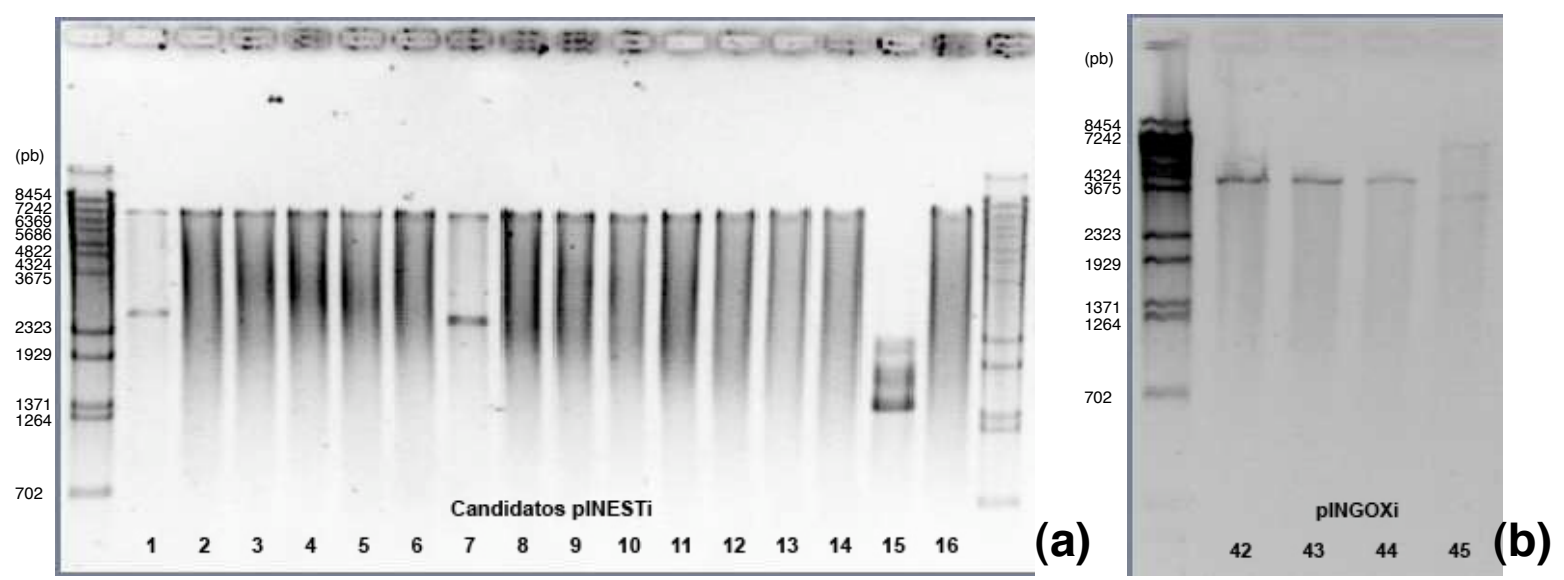

Figura 3.8. Confirmação por digestão com BamHI do ligamento de (a) INEST e (b) INGOX em pNADFL11. Os candidatos (a) 1 e 7 e (b) 45 mostram o padrão de bandas esperado: 6,8 kb para o plasmídeo e (a) 2,6 kb ou (b) 3,4 kb para o inserto. 
Inicialmente, foram realizadas tentativas de transformação de $K$. marxianus SLC33 e K. lactis PM5-3C com pINESTi e pINGOXi utilizando o método de acetato de lítio. Entretanto, só foi observado o aparecimento de colônias de K. lactis transformadas com ambos plasmídeos. Em cada caso, colônias que exibiam atividade de esterase extracelular ou de glicose oxidase foram selecionadas utilizando-se top-agar. No caso de $K$. lactis PM5-3C transformada com pINESTi, a seleção resultou em apenas uma colônia, a qual exibia atividade extracelular. Essa única colônia foi selecionada como a construção contendo o gene da esterase de Thermus thermophilus integrado ao DNA cromossomal de K. lactis. Já no caso da construção contendo o gene GOX, foram observadas 22 colônias de K. lactis PM53C cultivadas no meio seletivo CM-URA. Porém, apenas uma apresentou atividade extracelular, a qual foi detectada pelo método de top-agar. Esta linhagem foi selecionada como a produtora de GOX partindo da construção pINGOXi.

Contudo, permanecia o problema de não haver nenhum candidato de $K$. marxianus SLC33 contendo os genes de esterase ou GOX integrado ao seu DNA cromossomal, mesmo após 3 tentativas de transformação com o método de acetato de lítio. Apesar de a homologia entre a região de recombinação do plasmídeo e cromossomo consistir de $1,5 \mathrm{~kb}$, a integração não foi observada em nenhum caso com os dois genes. Como discutido anteriormente na integração do fragmento $U R A 3 \Delta$, o tamanho da região de homologia é um fator que influencia na recombinação. Ribeiro et al., (2007) descreveram uma baixa eficiência de recombinação homóloga em $K$. marxianus. Entretanto, esses autores e também Pecota et al. (2007) obtiveram sucesso na integração, porém utilizando como técnica de transformação a eletroporação.

Dessa forma, foi realizada a eletroporação para inserir os vetores contendo esterase e GOX em K. marxianus. Assim, obtiveram-se 21 candidatos na placa de transformação com o gene da esterase e 47 na placa de transformação com o gene GOX. Três candidatos com halo mais intenso foram selecionados pela técnica de top-agar.

A diferença na eficiência de transformação de $K$. marxianus pelo método de eletroporação em relação ao método de acetato de lítio foi patente. A maior quantidade de DNA transferida ao núcleo das células de $K$. marxianus por 
eletroporação aumentou a probabilidade de recombinação homóloga.

Os candidatos que possuíam os genes integrados ao DNA cromossomal e melhor produção de proteína extracelular (seleção descrita no item 4.5) tiveram a integração confirmada por PCR. A Figura 3.9 mostra a amplificação das bandas referentes ao gene da esterase a partir do DNA cromossomal de $K$. marxianus e $K$. lactis utilizando os primers PINUESTF e PINUESTR.

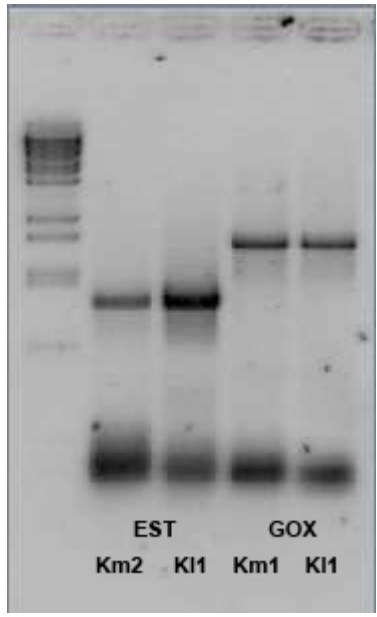

Figura 3.9. Confirmação da integração dos cassetes de expressão INEST e INGOX no DNA cromossomal de K. marxianus SLC33 e K. lactis PM5-3C por PCR. A confirmação da integração foi realizada nos candidatos que apresentaram maior nível de expressão de esterase e GOX em meio YPHSM-SUC.

\subsection{Construção de pSINEST e pSINGOX e transformação dos hospedeiros}

Para a construção desses vetores de expressão aproveitaram-se os cassetes já montados dos genes da esterase e GOX sob controle do promotor INU1 de $K$. marxianus CBS 6556, os quais foram inseridos no vetor epissomal pSPGK1. O ligamento foi confirmado por digestão utilizando a enzima Bam HI (Figura 3.10).

A transformação com pSINEST resultou em 46 colônias na placa contendo células de $K$. marxianus e em 35 colônias na placa contendo $K$. lactis. Já a transformação com pSINGOX resultou em 54 transformantes de K. marxianus e 21 transformantes de $K$. lactis. Em ambos os casos foram selecionadas três colônias pela técnica de top-agar. Porém, no caso da seleção de candidatos expressando esterase, cabe ressaltar que praticamente não se observava cor amarela referente à atividade enzimática, mas ainda assim foram selecionados os três candidatos que mais se destacavam frente aos outros. 

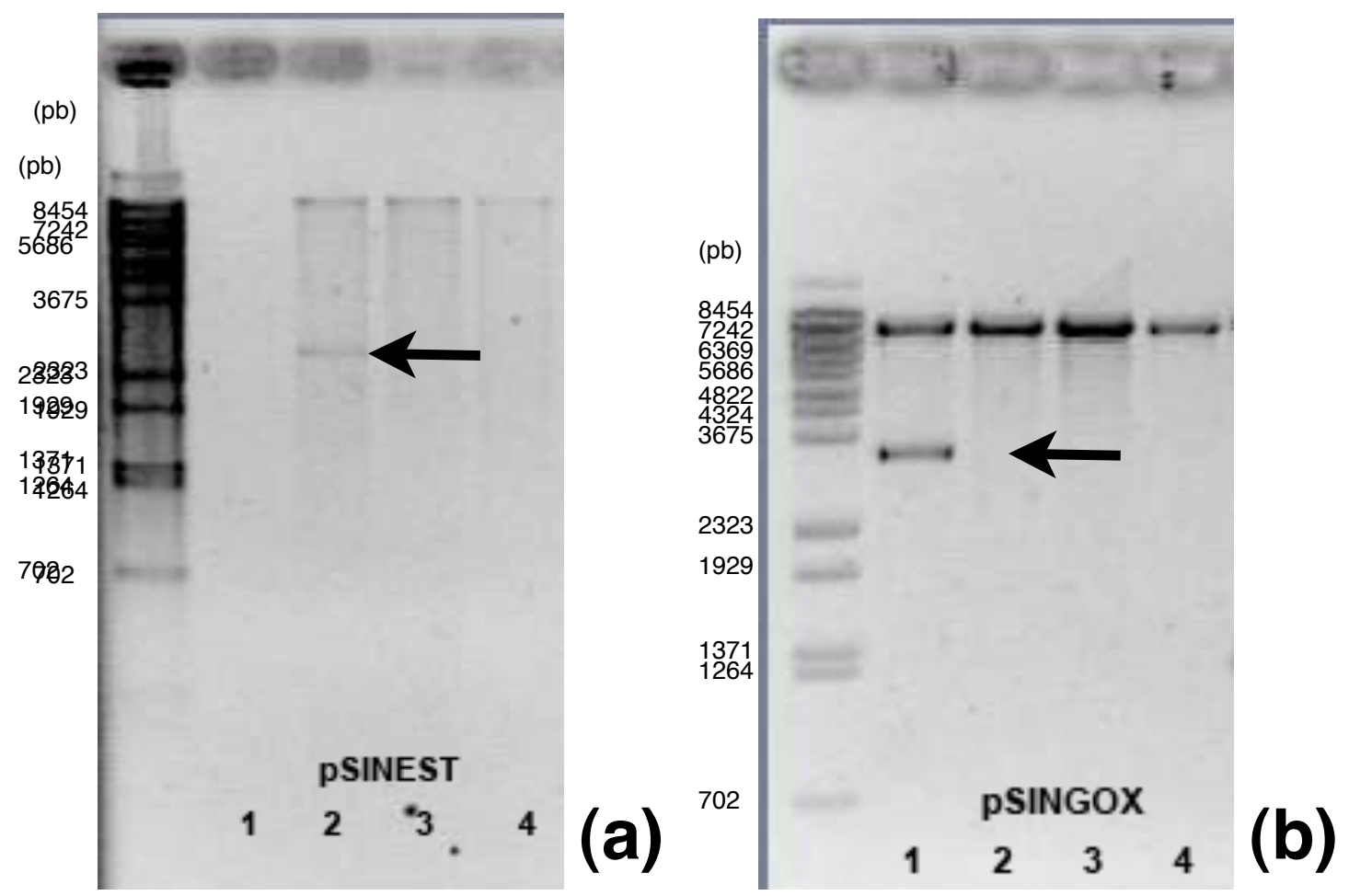

Figura 3.10. (a) Confirmação por digestão com BamHI do ligamento de INEST em pSPGK1. O candidato 2 (flecha) mostrou o padrão de bandas esperado: $8 \mathrm{~kb}$ para o plasmídeo e 2,6 kb para o inserto, resultando no plasmídeo pSINEST. (b) Confirmação por digestão com $B a m H I$ do ligamento de INGOX em pSPGK1. O candidato 1 (flecha) mostrou o padrão de bandas esperado: $8 \mathrm{~kb}$ para o plasmídeo e 3,4 kb para o inserto, resultando no plasmídeo pSINGOX.

\subsection{Seleção dos candidatos transformados}

\subsubsection{Com o gene da esterase termófila}

Após obter as diversas construções e células de $K$. marxianus e $K$. lactis expressando o gene da esterase de $T$. thermophilus, essas foram selecionadas em relação à capacidade de expressão extracelular em meio líquido. Como relatado ao longo do texto, a partir de cada construção, foram selecionados três candidatos de cada espécie em relação ao halo de atividade formado, resultando em um seleção inicial. Posteriormente, cada candidato foi crescido em meio YPHSM-SUC por 36 horas (tempo que corresponde a um ponto de máxima atividade, determinado por estudo cinético anterior) e a atividade de esterase foi medida no sobrenadante do cultivo. As atividades medidas para cada construção e linhagem de levedura estão listadas na Tabela 3.3.

O objetivo principal desta seleção foi o de escolher o candidato que 
expressasse a enzima heteróloga em níveis mais altos, a fim de ser utilizado nos estudos de expressão posteriores. Com isso, conclui-se que, com os dados de atividade específicas mostrados na Tabela 3.3, os candidatos que estão em negrito são os que melhor expressaram e excretaram esterase no meio, e, com isso, foram os utilizados para o estudo comparativo de expressão de cada construção e de caracterização bioquímica da enzima heteróloga. Um dado que se destaca é a alta produção do candidato $\mathrm{Km} 1$ contendo pSPEST frente aos outros dois contendo o mesmo plasmídeo, diferença esta que pode ser explicada por um eventual maior número de cópias do plasmídeo de expressão na linhagem $\mathrm{Km} 1$, em relação aos outros.

Tabela 3.3. Seleção dos candidatos transformados contendo as diferentes construções para expressão de esterase de Thermus thermophilus. Km: Kluyveromyces marxianus SLC33; KI: Kluyveromyces lactis PM5-3C.

\begin{tabular}{|c|c|c|c|c|}
\hline Construção & Candidato & $\mathbf{D O}_{600}$ & Atividade & Atividade Esp. ${ }^{*}$ \\
\hline \multirow{6}{*}{ pSPEST } & $\mathrm{Km} 1$ & 30,6 & $485 \mathrm{U} / \mathrm{L}$ & $23,8 \mathrm{U} / \mathrm{gMS}$ \\
\hline & $\mathrm{Km} 2$ & 26,2 & $19 \mathrm{U} / \mathrm{L}$ & $1,1 \mathrm{U} / \mathrm{gMS}$ \\
\hline & $\mathrm{Km} 3$ & 27,2 & $43 \mathrm{U} / \mathrm{L}$ & $2,4 \mathrm{U} / \mathrm{gMS}$ \\
\hline & $\mathrm{KI} 1$ & 25,8 & 282 U/L & $13,1 \mathrm{U} / \mathrm{gMS}$ \\
\hline & $\mathrm{KI} 2$ & 21,9 & 212 U/L & $11,6 \mathrm{U} / \mathrm{gMS}$ \\
\hline & $\mathrm{KI} 3$ & 27,0 & $307 \mathrm{U} / \mathrm{L}$ & $13,6 \mathrm{U} / \mathrm{gMS}$ \\
\hline \multirow{4}{*}{ pINESTi } & $\mathrm{Km} 1$ & 25,6 & $4 \mathrm{U} / \mathrm{L}$ & $0,2 \mathrm{U} / \mathrm{gMS}$ \\
\hline & $\mathrm{Km} 2$ & 26,2 & $14 \mathrm{U} / \mathrm{L}$ & $0,8 \mathrm{U} / \mathrm{gMS}$ \\
\hline & $\mathrm{Km} 3$ & 28,5 & $7 \mathrm{U} / \mathrm{L}$ & 0,4 U/gMS \\
\hline & KI 1 & 28,1 & $29 \mathrm{U} / \mathrm{L}$ & 1,3 U/gMS \\
\hline \multirow{6}{*}{ pSINEST } & $\mathrm{Km} 1$ & 25,5 & $7 \mathrm{U} / \mathrm{L}$ & $0,4 \mathrm{U} / \mathrm{gMS}$ \\
\hline & $\mathrm{Km} 2$ & 27,1 & $9 \mathrm{U} / \mathrm{L}$ & $0,5 \mathrm{U} / \mathrm{gMS}$ \\
\hline & $\mathrm{Km} 3$ & 26,7 & $14 \mathrm{U} / \mathrm{L}$ & $0,8 \mathrm{U} / \mathrm{gMS}$ \\
\hline & $\mathrm{KI} 1$ & 25,3 & $40 \mathrm{U} / \mathrm{L}$ & 1,9 U/gMS \\
\hline & KI 2 & 26,5 & $190 \mathrm{U} / \mathrm{L}$ & $8,6 \mathrm{U} / \mathrm{gMS}$ \\
\hline & $\mathrm{KI} 3$ & 26,2 & $68 \mathrm{U} / \mathrm{L}$ & $3,1 \mathrm{U} / \mathrm{gMS}$ \\
\hline
\end{tabular}

${ }^{*}$ A atividade específica foi calculada como sendo o quociente entre a atividade no sobrenadante $\mathrm{e}$ uma concentração celular estimada a partir de dados prévios de relação $\mathrm{DO}_{600}$ e massa seca (MS). Para K. marxianus $\mathrm{DO}_{600} / \mathrm{MS}=1,5$. Para $K$. lactis, $\mathrm{DO}_{600} / \mathrm{MS}=1,2$ (determinado a partir de dados experimentais).

Domínguez et al. (2007) atestam uma produção homóloga de esterase extracelular por $T$. thermophilus HB27 de $34 \mathrm{U} / \mathrm{L}$ em cultivo em batelada a $70^{\circ} \mathrm{C}$. A esta temperatura, a concentração celular alcançou o valor de $1 \mathrm{~g} / \mathrm{L}$, exibindo uma atividade específica de $34 \mathrm{U} / \mathrm{g}$ MS. No presente trabalho, em cultivos realizados para expressar alta quantidade de enzima e para caracterizá-la bioquimicamente, os valores de produção em levedura ultrapassaram a produção homóloga por $T$. thermophilus, como apresentado no Capitulo 5. 


\subsubsection{Com o gene da glicose oxidase}

Após obter as diversas construções e células de $K$. marxianus e $K$. lactis expressando o gene da GOX de $A$. niger, essas foram selecionadas em relação à capacidade de expressão extracelular em meio líquido. As atividades enzimáticas extracelulares, medidas após 36 horas de cultivo em meio YPHSM-SUC para cada construção e linhagem de levedura estão listadas na Tabela 3.4.

Tabela 3.4. Seleção dos candidatos transformados contendo as diferentes construções para expressão de GOX de A. niger. Km: Kluyveromyces marxianus SLC33; KI: Kluyveromyces lactis PM53C.

\begin{tabular}{|c|c|c|c|c|}
\hline Construção & Candidato & $\mathrm{DO}_{600}$ & Atividade & Atividade Esp. ${ }^{*}$ \\
\hline \multirow{6}{*}{ pSPGOX } & Km 1 & 26,5 & $75 \mathrm{U} / \mathrm{L}$ & $4,3 \mathrm{U} / \mathrm{gMS}$ \\
\hline & $\mathrm{Km} 2$ & 24,3 & $0 \mathrm{U} / \mathrm{L}$ & $0 \mathrm{U} / \mathrm{gMS}$ \\
\hline & $\mathrm{Km} 3$ & 27,5 & $0 \mathrm{U} / \mathrm{L}$ & $0 \mathrm{U} / \mathrm{gMS}$ \\
\hline & KI 1 & 26,8 & $210 \mathrm{U} / \mathrm{L}$ & 9,4 U/gMS \\
\hline & $\mathrm{KI} 2$ & 25,8 & $150 \mathrm{U} / \mathrm{L}$ & $7,0 \mathrm{U} / \mathrm{gMS}$ \\
\hline & $\mathrm{KI} 3$ & 26,2 & $170 \mathrm{U} / \mathrm{L}$ & 7,6 U/gMS \\
\hline \multirow{4}{*}{ pINGOXi } & $\mathrm{Km} 1$ & 28,3 & $38 \mathrm{U} / \mathrm{L}$ & $2,0 \mathrm{U} / \mathrm{gMS}$ \\
\hline & $\mathrm{Km} 2$ & 29,5 & $0 \mathrm{U} / \mathrm{L}$ & $0 \mathrm{U} / \mathrm{gMS}$ \\
\hline & $\mathrm{Km} 3$ & 28,7 & $14 \mathrm{U} / \mathrm{L}$ & $0,7 \mathrm{U} / \mathrm{gMS}$ \\
\hline & KI 1 & 26,5 & $150 \mathrm{U} / \mathrm{L}$ & 6,8 U/gMS \\
\hline \multirow{6}{*}{ pSINGOX } & Km 1 & 24,1 & $71 \mathrm{U} / \mathrm{L}$ & 4,2 U/gMS \\
\hline & $\mathrm{Km} 2$ & 26,0 & $48 \mathrm{U} / \mathrm{L}$ & $2,8 \mathrm{U} / \mathrm{gMS}$ \\
\hline & $\mathrm{Km} 3$ & 30,8 & $14 \mathrm{U} / \mathrm{L}$ & $0,7 \mathrm{U} / \mathrm{gMS}$ \\
\hline & KI 1 & 25,9 & $21 \mathrm{U} / \mathrm{L}$ & $1,0 \mathrm{U} / \mathrm{gMS}$ \\
\hline & $\mathrm{KI} 2$ & 26,5 & $18 \mathrm{U} / \mathrm{L}$ & $0,8 \mathrm{U} / \mathrm{gMS}$ \\
\hline & KI 3 & 23,5 & $33 \mathrm{U} / \mathrm{L}$ & $1,7 \mathrm{U} / \mathrm{gMS}$ \\
\hline
\end{tabular}

* A atividade específica foi calculada como sendo o quociente entre a atividade no sobrenadante e uma concentração celular estimada a partir de dados prévios de relação $\mathrm{DO}_{600}$ e massa seca (MS). Para K. marxianus $\mathrm{DO}_{600} / \mathrm{MS}=1,5$. Para K. lactis, $\mathrm{DO}_{600} / \mathrm{MS}=1,2$.

As linhagens que expressaram e excretaram maior quantidade de glicose oxidase foram destacadas em negrito na Tabela 3.4. No entanto, as atividades enzimáticas determinadas ficaram muito abaixo de níveis já publicados para outros sistemas de expressão. Malherbe et al. (2003) construíram um sistema integrativo de expressão de GOX em S. cerevisiae em que o gene era expresso sob controle do promotor PGK e possuía o sinal de secreção $M F \alpha$, ambos de $S$. cerevisiae. Com esse sistema, foi obtida apenas uma cópia do gene inserido no DNA cromossomal da levedura. Assim mesmo, níveis de produção de $100 \mathrm{U} / \mathrm{mL}$ ou $50 \mathrm{U} / \mathrm{mgMS}$ foram obtidos. Park et al. (2000), também em S. cerevisiae, obtiveram valores de atividade que variavam entre 34 e $460 \mathrm{U} / \mathrm{mL}$, variando o promotor utilizado entre os dos genes GAL1, GAL7, GAL10 e ADH2 do mesmo organismo. 
Os dados de Park et al. (2000) diferem em ordem de grandeza dos valores obtidos neste trabalho. Alguns problemas podem ter ocorrido nesta seleção. As condições de cultivo podem não ter sido apropriadas para a expressão do gene heterólogo, como a força iônica ou o próprio meio utilizado. O que foi feito para aumentar os níveis de produção (técnica descrita nos Capítulos 4 e 5) foi utilizar a estratégia descrita por Bergkamp et al. (1993), que consistia em crescer as leveduras em um meio seletivo e depois passá-las a um meio complexo não seletivo. Dessa forma, o meio de produção era inoculado apenas por células transformadas.

Apenas para a comparação visual da expressão de GOX nos candidatos selecionados, foram dispostos em uma placa CM-URA contendo sacarose a $2 \%$ como única fonte de carbono todos os candidatos testados por cultivo em meio líquido (Figura 3.11). Verificou-se na placa uma maior expressão de GOX com $K$. lactis contendo pSPGOX. A construção integrativa, na placa de Petri, mostrou maior atividade em K. marxianus em relação a K. lactis, contrariando os dados obtidos em meio líquido. Bem como a construção pSINGOX que em $K$. marxianus mostrou atividade nula em placa. Já em $K$. lactis, apresentou um halo de atividade de pouca intensidade, contrariando também os dados obtidos em meio líquido. Esses dados vêm a corroborar a influência do meio de cultivo na expressão heteróloga de GOX.

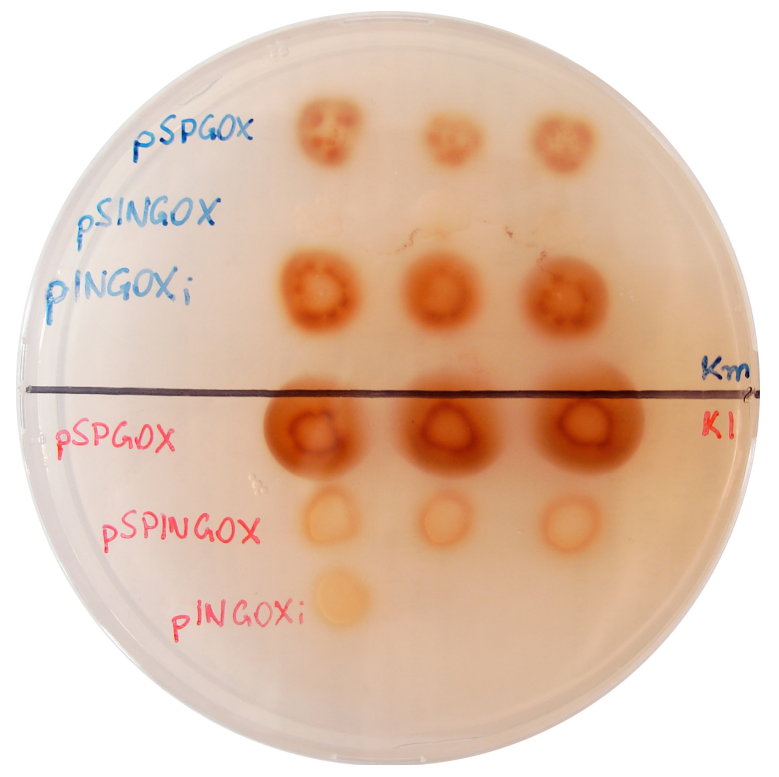

Figura 3.11. Comparativo da expressão de GOX em placa CM-URA (contendo sacarose a $2 \%$ como única fonte de carbono). Os candidatos de $K$. marxianus $(K m)$ estão denominados em tinta azul e os de $K$. lactis $(K I)$, em tinta vermelha. Da esquerda para a direita estão dispostos os candidatos de 1 a 3 de cada construção. $O$ tempo de incubação da placa a $37^{\circ} \mathrm{C}$, neste caso foi de 6 horas. 


\section{Conclusões}

Nesta parte do trabalho, foi obtida uma linhagem derivada de $K$. marxianus CBS 6556 mutante, deficiente na síntese de uracila, por seleção em placas contendo 5-FOA. A tentativa de deleção do gene URA3, o qual codifica para a síntese de uma enzima essencial presente na via de biossíntese dessa base nitrogenada, não foi efetuada com sucesso. Indica-se como causa principal do insucesso a ineficiência da recombinação homóloga em $K$. marxianus, já descrita na literatura e, eventualmente, a ploidia ou existência de mais de um alelo.

Além disso, foram construídos sistemas heterólogos para expressão de uma esterase de Thermus thermophilus e da glicose oxidase de Aspergillus niger, conforme resumido na Tabela 3.5.

Tabela 3.5. Resumo das construções realizadas nesta etapa do trabalho.

\begin{tabular}{lccccc}
\hline Organismo & Vetor & Promotor & $\begin{array}{c}\text { Sinal de } \\
\text { Secreção }\end{array}$ & Terminador & Gene \\
\hline K. marxianus & pSPGK1 & PGK & k1 & PGK & EST \\
& pSPGK1 & PGK & k1 & PGK & GOX \\
& pSPGK1 & INU1 & INU1 & INU1 & EST \\
& pSPGK1 & INU1 & INU1 & INU1 & GOX \\
& pNADFL11 & INU1 & INU1 & INU1 & EST \\
& pNADFL11 & INU1 & INU1 & INU1 & GOX \\
& pSPGK1 & PGK & k1 & PGK & EST \\
& pSPGK1 & PGK & k1 & PGK & GOX \\
& pSPGK1 & INU1 & INU1 & INU1 & EST \\
& pSPGK1 & INU1 & INU1 & INU1 & GOX \\
& pNADFL11 & INU1 & INU1 & INU1 & EST \\
& pNADFL11 & INU1 & INU1 & INU1 & GOX \\
\hline
\end{tabular}


Capítulo 4

\section{Expressão Heteróloga da Glicose Oxidase de A. niger na Levedura Kluyveromyces marxianus}

Artigo aceito para publicação na revista Microbial Cell Factories 


\section{EXPRESSÃO HETERÓLOGA DA GLICOSE OXIDASE DE A. niger NA LEVEDURA Kluyveromyces marxianus}

Saul Nitsche Rocha1, José Abrahão-Neto², María Esperanza Cerdán³, María Isabel González-Siso ${ }^{3}$ e Andreas Karoly Gombert ${ }^{1 \S}$

${ }^{1}$ Departamento de Engenharia Química, Universidade de São Paulo, CP 61548, 05424-970, São Paulo-SP, Brasil

2 Faculdade de Ciências Farmacêuticas, Universidade de São Paulo, Av. Prof. Lineu Prestes, 580, bloco 15, 05508-900, São Paulo-SP, Brasil

${ }^{3}$ Departamento de Bioloxía Celular e Molecular, Facultade de Ciencias, Universidade da

Coruña, Campus da Zapateira s/n, 15071-A Coruña, Espanha

$\S$ Autor para corespondência

E-mail: andreas.gombert@poli.usp.br

FAX: +551130912284

\section{Resumo}

Apesar das propriedades fisiológicas vantajosas para aplicações em bioprocessos, o uso da levedura Kluyveromyces marxianus como hospedeira na produção de proteínas heterólogas vem sendo muito limitado, em contraste à sua congênere $K$. lactis. No presente trabalho, a proteína modelo glicose oxidase (GOX) de Aspergillus niger foi clonada nas linhagens K. marxianus CBS 6556 e K. lactis CBS 2359, utilizando três diferentes sistemas de expressão. O objetivo deste estudo foi verificar como cada sistema de expressão influencia na expressão da proteína, secreção, localização, modificações pós-traducionais e propriedades bioquímicas. Os resultados obtidos mostram que os níveis mais altos de expressão (1552 unidades de atividade de enzima secretada por grama de biomassa seca) foram alcançados utilizando-se um sistema epissomal, no qual o promotor e terminador INU1 foram utilizados para conduzir a expressão heteróloga do gene. Em todos os casos, a GOX foi preferencialmente secretada, sendo encontrada tanto no espaço periplásmico quanto no sobrenadante. Considerando que o uso de elementos genéticos de $S$. cerevisiae para promover a expressão heteróloga resultou em mais altos níveis de expressão em $K$. lactis que em $K$. marxianus, a utilização de elementos genéticos de INU1 nitidamente levou ao resultado oposto. A 
caracterização bioquímica de GOX confirmou a correta expressão da proteína e mostrou que $K$. marxianus tem a tendência de hiperglicosilar a proteína heteróloga de maneira similar ao observado em outras leveduras, embora essa tendência pareça ser menor que em K. lactis. A hiperglicosilação de GOX não afeta sua afinidade ao substrato, tampouco sua atividade, de maneira significativa. Os resultados obtidos indicam que $K$. marxianus é, de fato, um bom hospedeiro para a expressão de proteínas heterólogas, não somente pelas suas propriedades fisiológicas, como também pelo fato de essa espécie ser capaz de secretar e editar esses peptídeos de maneira eficiente.

\section{Introdução}

Kluyveromyces marxianus é uma espécie geneticamente próxima a $K$. lactis, uma levedura Crabtree-negativa modelo, a qual já fora investigada intensivamente pela comunidade científica (Bellaver et al., 2004; Kiers et al., 1998; van Ooyen et al., 2006). Em contrapartida, K. marxianus ainda não foi alvo de muita investigação. Para esta espécie, não há genoma seqüenciado, sistema de clonagem comercial, tampouco uma linhagem referência utilizada em pesquisas básicas (Fonseca et al., 2008). Não obstante, vem sendo constantemente apontada como candidata a aplicações biotecnológicas, devido às suas propriedades fisiológicas, como termotolerância, capacidade de catabolizar mais substratos que $S$. cerevisiae, um metabolismo fortemente Crabtree-negativo (Bellaver et al., 2004; Fonseca et al., 2007), o qual resulta em altas conversões de substrato em biomassa e pequena formação de metabólitos indesejados. Além disso, foi considerada como o eucarioto de mais rápido crescimento do planeta (Groeneveld et al., 2009).

A ausência de uma comunidade de pesquisa organizada em relação à espécie K. marxianus causa dificuldade em se extrair informações objetivas sobre aspectos básicos dessa linhagem. Várias linhagens diferentes foram descritas na literatura, muitas delas não disponíveis em coleções de culturas internacionais. Em contrapartida, existe um amplo campo de exploração dessa espécie para aplicações industriais. Dentre elas, a produção de proteínas heterólogas é especialmente atrativa, tendo em vista as propriedades fisiológicas chave indicadas acima. Outras 
leveduras já foram mais extensivamente estudadas para esse propósito. Além da $S$. cerevisiae, os hospedeiros mais comuns para a expressão de proteínas heterólogas são a Pichia pastoris, Hansenula polymorpha, Yarrowia lipolytica e também K. lactis (van Ooyen et al., 2006; Daly e Hearn, 2005; Cox et al., 2000; Madzak et al., 2005; Müller et al., 2005; Porro et al., 1998). Para muitas dessas espécies, a pesquisa está relativamente avançada, com trabalhos atuais focando em aspectos como a humanização das vias secretórias, também referida como glico-engenharia, essencial para a produção de proteínas terapêuticas (Wildt e Gerngross, 2005; Hamilton e Gerngross, 2007) e para a procura de fenótipos super-secretores (Raimondi et al., 2008).

A expressão de genes heterólogos em $K$. marxianus foi reportada em alguns poucos artigos. Após o trabalho pioneiro de Bergkamp et al. (1993), os quais expressaram a enzima alfa-galactosidase da planta Cyamopsis tetragonoloba à concentração de 153 mg/L com 99\% de eficiência de secreção (incluindo ambas frações periplásmica e extracelular), levou um certo tempo antes que Ball et al. (1999) reportassem a expressão de $\beta$-glucosidase intracelular a $10 \mathrm{U} / \mathrm{mg}$ de proteína total do extrato (dado obtido a partir de um gráfico). Após, Almeida et al. (2003) expressaram o gene que codifica para a enzima giceraldeído-3-fosfato desidrogenase de uma linhagem floculenta de $K$. marxianus em outra linhagem da mesma espécie que não flocula, provocando a floculação desta. Pecota et al. (2005) reportaram a produção intracelular de $\beta$-glucuronidase heteróloga em K. marxianus. Na mesma época, Cai et al. (2005) publicaram a expressão extracelular de interferon a-2a a 60 mg/L numa linhagem de $K$. cicerisporus (sinônima de K. marxianus). Em seguida, Pecota et al. (2007) expressaram lactato desidrogenase de Bacillus megaterium em $K$. marxianus utilizando a primeira construção integrativa reportada para esta espécie. Hong et al. (2007), por sua vez, expressaram simultaneamente as seguinte enzimas termoestáveis: endo- $\beta$-1,4-glucanase, celobioidrolase e $\beta$ glucosidase, construindo uma linhagem capaz de crescer utilizando celobiose ou carboximetilcelulose como únicas fontes de carbono. Mais recentemente, Nonklang et al. (2008) publicaram a expressão de $\alpha$-amilase de Aspergillus oryzae em $\mathrm{K}$. marxianus.

Em relação à capacidade de $K$. marxianus de glicosilar proteínas, existe muito 
pouca informação disponível. Siekstele et al. (1999) expressaram o gene da endopoligalacturonase (EPG1) de K. marxianus em uma linhagem que possuía o mesmo gene inativo. Em contraste à linhagem que expressava o gene EPG1 nativo, a expressão heteróloga levou à formação de uma proteína de peso molecular mais alto, além de uma similar à nativa, sugerindo que a primeira forma estivesse mais glicosilada que a última. Schwan et al. (1997) estudaram a secreção de poligalacturonases nativas em K. marxianus. Pelo menos quatro isoenzimas foram identificadas a partir do peso molecular, o que pode ser devido a diferentes padrões de glicosilação da mesma enzima, segundo os autores. Rouwenhorst et al. (1990) verificaram a dispersão das bandas de inulinase de $K$. marxianus CBS 6556 em géis de eletroforese, tanto de enzimas presentes no sobrenadante quanto no periplasma. Essa observação foi atribuída à heterogeneidade do tamanho da cadeia de açúcares ligados ao peptídeo da inulinase.

Neste estudo, a enzima glicose oxidase (EC 1.1.3.4), a qual catalisa a oxidação de glicose para gluconolactona e a subseqüente redução de oxigênio para peróxido de hidrogênio, foi utilizada como proteína-modelo para expressão heteróloga em Kluyveromyces marxianus. Essa enzima possui um grupamento FAD ligado em cada monômero com forte interação, porém não covalente. Além disso, é um dímero com massa molecular que varia entre 130-320, dependendo dos tamanhos das cadeias de açúcares nas glicosilações. A enzima nativa é glicosilada, sendo que a porcentagem de carboidrato em massa é de 16-25\% (Kohen et al., 1993). A enzima expressada em S. cerevisiae gerou um produto altamente glicosilado, com massa de carboidrato relativa ao peso total da proteína de 60\% (Frederick et al., 1990). Com o objetivo de avaliar o potencial de K. marxianus como hospedeira na síntese de proteínas heterólogas, não somente em termos de produtividade, mas também em termos de glicosilação, localização e propriedades bioquímicas do produto, foi clonado o gene da GOX de Aspergillus niger BT18 em K. marxianus CBS 6556 e em K. lactis CBS 2359, utilizando-se construções epissomais e integrativas. Esta proteína oferece um grande potencial de comparação com outros sistemas de expressão. Até onde se conhece, este é o primeiro trabalho que relata um estudo de produção heteróloga de proteínas em $K$. marxianus em que o padrão de glicosilação, localização, estabilidade e propriedades cinéticas foram investigadas. Três diferentes sistemas de expressão foram usados para a expressão de GOX, 
paralelamente em $K$. marxianus e em $K$. lactis, o que permite realizar uma comparação direta entre os dois organismos.

\section{Materiais e métodos}

\subsection{Linhagens e meios de cultivo}

Escherichia coli DH10b (Invitrogen, EUA) foi utilizada para a construção e propagação dos plasmídeos. Kluyveromyces marxianus CBS 6556 foi adquirida do Centraal Bureau voor Schimmelcultures (Ultrecht, Holanda). Kluyveromyces lactis PM5-3C (MATa uraA $\mathrm{Rag}^{+}$) foi gentilmente cedida pela Dra. Micheline WesolowskiLouvel (Lyon, França). Saccharomyces cerevisiae BY4742 (MATa his3D1 leuD0 lys2D0 ura3D0) (Brachmann et al., 1998) foi fornecida pelo Euroscarf (Frankfurt, Alemanha). A linhagem K. marxianus SLC33 é um mutante ura3 de K. marxianus CBS 6556, construída neste trabalho por seleção em ágar contendo 5-FOA (a estabilidade do fenótipo ura- foi comprovada por 120 gerações).

A linhagem de $E$. coli foi cultivada em meio LB ( $1 \%$ triptona, $0,5 \%$ extrato de levedura, $0,5 \% \mathrm{NaCl}, 0,1 \%$ glicose), em meio líqüido ou sólido ( $2 \%$ bacto-agar) a 37 ${ }^{\circ} \mathrm{C}$. Para seleção de transformantes, ampicilina foi adicionada a concentração final de $40 \mathrm{mg} / \mathrm{L}$. Para a seleção das leveduras que apresentam expressão de URA3, foi utilizado o meio CM (Zitomer et al., 1976) sem uracila (CM-URA). As placas contendo 5-FOA para a seleção de mutantes ura3 foram feitas segundo descrito por Boeke et al., 1984). O primeiro screening das leveduras que expressavam GOX foi feito em meio YPHSM-SUC (8\% peptona, 1\% extrato de levedura, 3\% glicerol, 1\% sacarose). Para os estudos de expressão de GOX, as linhagens foram cultivadas em meio definido (MD) descrito por Verduyn et al. (1992) e em seguida em meio YPS ( $1 \%$ extrato de levedura, $2 \%$ peptona, $2 \%$ sacarose). 


\subsection{Isolamento e manipulação de ácidos nucléicos}

DNA plasmidial de E. coli foi obtido utilizando o kit Spin Clean Plasmid Miniprep (Mbiotech, Coréia do Sul). O DNA plasmidial das células de levedura foi extraído utilizando-se o mesmo kit comercial da extração em bactérias, com a diferença dos seguintes passos: antes da miniprep normal, $10 \mathrm{~mL}$ de um cultivo de $24 \mathrm{~h}$ em meio $\mathrm{CM}$ foram centrifugados. O pellet foi ressuspendido em $250 \mu \mathrm{L}$ de tampão de ressuspensão e $250 \mu \mathrm{L}$ de tampão de lise (fornecidos com o kit) e aproximadamente $250 \mu \mathrm{L}$ de pérolas de vidro (425-600 $\mu \mathrm{m}$, Sigma, EUA). A mistura foi agitada em vórtex vigorosamente por 2 minutos e mantida em gelo por mais 5 minutos. Logo após, o protocolo de miniprep foi seguido. A suspensão final de DNA foi utilizada diretamente para transformação de $E$. coli para propagação do plasmídeo. A transformação das leveduras por acetato de lítio foi realizada conforme descrito por Ito et al. (1983). Já o método de transformação por eletroporação foi adaptado do protocolo descrito por Kooistra et al. (2004), como descrito a seguir. $10 \mathrm{~mL}$ de uma cultura de leveduras no início da fase exponencial foram centrifugados (4000 x g, 5 minutos) e lavados com $1 \mathrm{~mL}$ de água ultrapura. Em seguida, as células foram ressuspendidas em $1 \mathrm{~mL}$ de tampão de pré-tratamento (meio YPD contendo 200 mM DTT e $300 \mathrm{mM}$ HEPES) e incubadas a $30^{\circ} \mathrm{C}$ por 30 minutos. Então, as células foram centrifugadas ( $4000 \times \mathrm{g}, 5$ minutos) e ressuspendidas em $1 \mathrm{~mL}$ de tampão de eletroporação (10 mM Tris- $\mathrm{HCl} \mathrm{pH} \mathrm{7,5,} \mathrm{sacarose} 270 \mathrm{mM}$, acetato de lítio $1 \mathrm{mM}$ ). O choque elétrico foi realizado segundo os seguintes parâmetros: $25 \mu \mathrm{F}, 550 \mathrm{~V}, 600 \Omega$.

As reações de PCR foram realizadas em um volume final de $25 \mu \mathrm{L}$ que continham $20 \mathrm{ng}$ do DNA molde, $30 \mathrm{pmol}$ de cada primer (Tabela 4.1), 1,75 nmol de cada dNTP, $\mathrm{KCl} 50 \mathrm{mM}, \mathrm{MgCl}_{2}$ 2,5 mM, 0,25 U de Taq DNA polimerase (Roche Diagnostics, Alemanha). A mistura foi tamponada em tampão Tris- $\mathrm{HCl} 10 \mathrm{mM}, \mathrm{pH}$ 8,3. Após, as reações foram executadas em 30 ciclos: desnaturação $\left(94^{\circ} \mathrm{C}\right.$ por 30 segundos), anelamento $\left(50{ }^{\circ} \mathrm{C}\right.$ para o gene da GOX e $53{ }^{\circ} \mathrm{C}$ para o cassete INU1 por 60 segundos) e extensão a $72{ }^{\circ} \mathrm{C}$ por 2,5 minutos (GOX) e 3 minutos (INU1). Todas as outras manipulações foram executadas conforme descrito por Sambrook et al. (2001). 
Tabela 4.1. Lista dos primers utilizados nas construções de DNA.

\begin{tabular}{|c|c|c|}
\hline Primer & Seqüência & Detalhes \\
\hline PSPGOXR & $\begin{array}{l}\text { 5' - TTTTTGCTGTCATTCGTTCAAGG } \\
\text { TAAAAGAAGCAATGGCATTGAAGCC } \\
\text { 5' - CACCACCACCAGTAGAGACATG } \\
\text { GGAGATCGTCACTGCATGGAAGCATA }\end{array}$ & $\begin{array}{l}\text { Amplificar o gene GOX do plasmídeo } \\
\text { pBT86. Possui uma cauda para } \\
\text { recombinação em pSPGK1 (sublinhado) }\end{array}$ \\
\hline PINU1Fb & $\begin{array}{l}\text { 5’- GGATCCGAATTCTCAAACCGAA } \\
\text { ATGGG }\end{array}$ & \multirow{2}{*}{$\begin{array}{l}\text { Amplificar o cassete INU1 (promotor + } \\
\text { sinal de secreção + CDS + terminador) } \\
\text { de K. marxianus CBS6556. A região } \\
\text { sublinhada se refere a um sítio de } \\
\text { restrição BamHI adicionado. }\end{array}$} \\
\hline PINU1Rb & $\begin{array}{l}\text { 5'- GGATCCACGCCAGACGTCTTGTGT } \\
\text { CCG }\end{array}$ & \\
\hline PINUGOXF & $\begin{array}{l}5^{\prime} \text {-GTCAGTGCTTCAGTTATCAATTAC } \\
\text { AAGAGA AGCAATGGCATTGAAGCC }\end{array}$ & \multirow{2}{*}{$\begin{array}{l}\text { Amplificar o gene da GOX de A. niger. } \\
\text { Possui cauda de recombinação } \\
\text { (sublinhada) para a seqüência sinal de } \\
\text { secreção (PINUGOXF) e terminador } \\
\text { (PINUGOXR) do gene INU1 }\end{array}$} \\
\hline PINUGOXR & $\begin{array}{l}\text { 5'- TTTTGTCGTTAGTAAAGTAAGCAG } \\
\text { ATCAGA TCACTGCATGGAAGCATA }\end{array}$ & \\
\hline
\end{tabular}

\subsection{Construção dos plasmídeos e transformação das leveduras}

O vetor epissomal pSPGOX (Figura 4.1A) foi construído como descrito a seguir. O gene GOX de A. niger BT18 foi amplificado por PCR do plasmídeo pBT86 (cedido pelo Dr. Oscar Bañuelos, Puleva Biotech Inc., Espanha) utilizando os primers PRPGOXF e PSPGOXR (Tabela 4.1). O fragmento de 1,8 kb amplificado foi clonado no plasmídeo replicativo pSPGK1 (Fleer et al., 1991). Esse plasmídeo possui a origem de replicação S11 de K. lactis, apresentado habilidade de se replicar tanto em células de $K$. lactis quanto de $K$. marxianus. A inserção da CDS de GOX foi realizada por recombinação homóloga do produto de PCR com pSPGK1 linearizado com EcoRI. Quantidades iguais de plasmídeo e inserto (500 ng) foram utilizados para transformar $K$. lactis PM5-3C pelo método de acetato de lítio. Os transformantes apresentaram capacidade de crescimento no meio seletivo CM-URA. A confirmação da recombinação foi feita por PCR, amplificando a CDS de GOX a partir dos plasmídeos com os primers PSPGOXF e PSPGOXR e também pela expressão extracelular de GOX em top-agar, conforme descrito por Malherbe et al. (2003). Finalmente, os plasmídeos foram extraídos de $K$. lactis e utilizados para transformar K. marxianus SLC33 pelo método de acetato de lítio.

As construções que utilizaram o cassete INU1 para a expressão de GOX iniciaram com a amplificação do cassete INU1 a partir do DNA cromossomal de $K$. marxianus CBS 6556 utilizando os primers PINU1Fb e PINU1Rb (Tabela 4.1). Ambos os primers possuíam em suas extremidades 5' um sítio de restrição BamHI. 
Após a amplificação, o cassete INU1 foi ligado no vetor pMBL1-T (Mbiotech, Coréia do Sul) para propagação. Então o inserto foi retirado por digestão com BamHI e o cassete clonado no vetor Yeplac 195. A construção resultante foi linearizada com Tth111I. Em paralelo, a CDS da GOX foi amplificada a partir do plasmídeo pBT86 utilizando os primers PINUGOXF e PINUGOXR (Tabela 4.1). Esses dois primers eram capazes de adicionar extremidades ao gene amplificado, as quais eram homólogas ao sinal de secreção e terminador INU1. O fragmento resultante foi clonado no vetor pMBL1-T para propagação. Para a inserção da CDS de GOX em INU1, o vetor Yeplac195 contendo INU1 linearizado e o fragmento amplificado de GOX foram fundidos por recombinação homóloga em S. cerevisiae BY4727, transformada com igual proporção de plasmídeo e inserto (500 ng) pelo método de acetato de lítio. A construção foi extraída de células de $S$. cerevisiae e digeridas com BamHI, o que fez com que o cassete de expressão de GOX fosse liberado. Após propagação do cassete de 3,4 kb em pMBL1-T, esse fragmento foi clonado nos plasmídeos de expressão pSPGK1 e pNADFL11 no sítio BamHI, resultando nas construções epissomal e integrativa mostradas nas Figuras 4.1B e 4.1C, respectivamente. Mais detalhes sobre todas estas construções genéticas encontram-se no capítulo 3 desta tese.

Os vetores de expressão foram usados para transformar K. marxianus SLC 33 e K. lactis PM5-3C pelo método de acetato de lítio, com exceção da construção integrativa em K. marxianus. Neste caso, a levedura foi transformada por eletroporação, já que o método químico não foi eficiente. As construções estão detalhadas na Tabela 4.2 e na Figura 4.1.

Após a transformação das leveduras com cada construção, os transformantes que apresentaram maior atividade de GOX extracelular foram selecionados por topagar. As colônias que apresentaram maiores atividades eram circundadas por um halo marrom maior. Três transformantes de cada construção que apresentaram maior atividade foram selecionados. Na seqüência, os candidatos escolhidos foram crescidos em meio líquido YPHSM-SUC por $36 \mathrm{~h}$ e a atividade de GOX foi determinada. Os candidatos de cada construção que apresentaram maior atividade foram selecionados para os estudos posteriores. 
Tabela 4.2. Lista das seis construções obtidas neste trabalho e seus detalhes.

\begin{tabular}{|c|c|c|c|c|c|c|}
\hline Construção & $\begin{array}{c}\text { Espécie } \\
\text { hospedeira }\end{array}$ & $\begin{array}{l}\text { Nome do } \\
\text { plasmídeo }\end{array}$ & Tipo & Promotor & $\begin{array}{l}\text { Sinal de } \\
\text { secração }\end{array}$ & Terminador \\
\hline $\mathrm{Km} 1$ & K. marxianus & pSPGOX & Epissomal & Sc PGK & $K / \mathrm{k} 1$ & Sc PGK \\
\hline $\mathrm{Km} 2$ & K. marxianus & pSPINGOX & Epissomal & Km INU1 & Km INU1 & Km INU1 \\
\hline $\mathrm{Km} 3$ & K. marxianus & pINGOXi & Integrativo & Km INU1 & Km INU1 & Km INU1 \\
\hline $\mathrm{K} / 1$ & K. lactis & pSPGOX & Epissomal & Sc PGK & $K / \mathrm{k} 1$ & Sc PGK \\
\hline $\mathrm{K} 12$ & K. lactis & pSPINGOX & Epissomal & Km INU1 & Km INU1 & Km INU1 \\
\hline $\mathrm{KI} 3$ & K. lactis & pINGOXi & Integrativo & Km INU1 & Km INU1 & Km INU1 \\
\hline
\end{tabular}

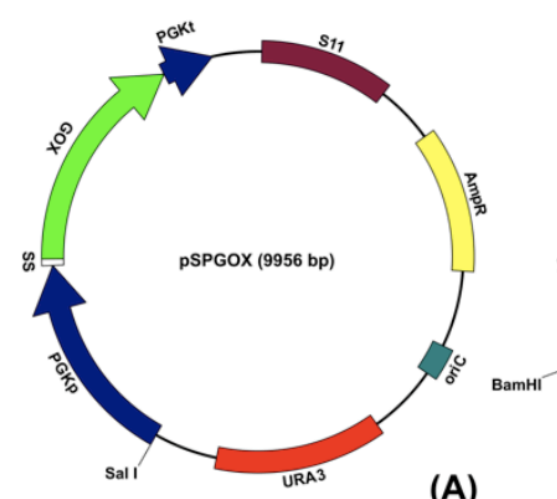

(A)

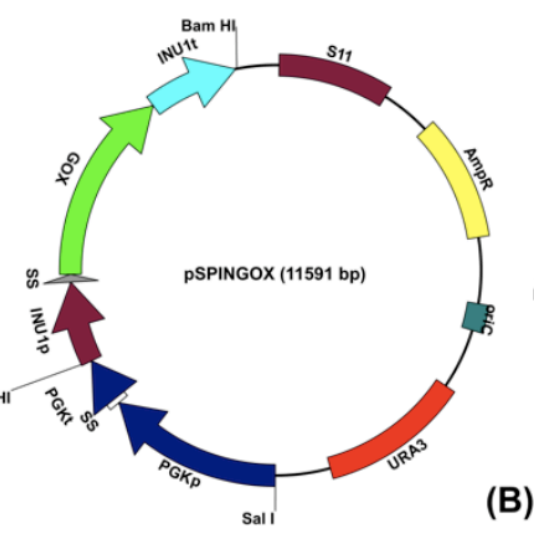

(B)

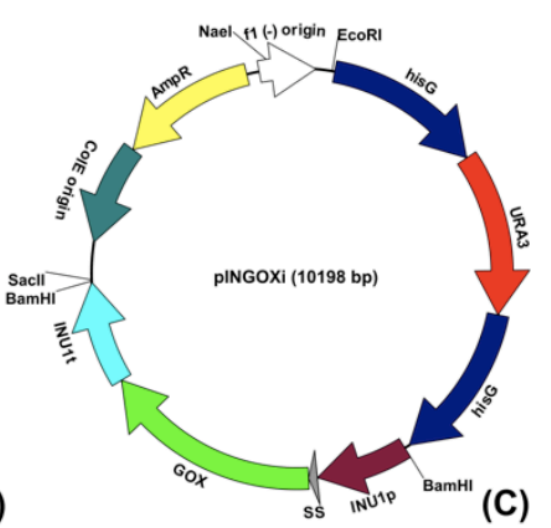

Figura 4.1. Sistemas de expressão desenvolvidos neste trabalho. (A) pSPGOX promove expressão epissomal de GOX sob controle do promotor ScPGK; (B) pSPINGOX é um vetor epissomal que permite a expressão de GOX sob controle do promotor KmINU1; (C) pINGOXi é um plasmídeo integrativo que confere à célula capacidade de expressar GOX sob controle do promotor KmINU1. (A) e (B) derivam do vetor pSPGK1 (Fleer et al., 1991) e (C) do pNADFL11 (Pecota et al., 2007). Legenda: $p$, promotor; $t$, terminador; $S S$, sinal de secreção.

\subsection{Análise da produção de GOX em cultivos submersos}

As condições descritas por Bergkamp et al. (1993), as quais resultaram em uma produção extracelular eficiente da enzima alfa-galactosidase em $K$. marxianus, foram adotadas com pequenas modificações. Os transformantes foram crescidos em frascos chicanados de $500 \mathrm{~mL}$ contendo $100 \mathrm{~mL}$ de meio, agitados a $300 \mathrm{rpm}$ e incubados a $30{ }^{\circ} \mathrm{C}$. Primeiramente, as células foram cultivadas por $24 \mathrm{~h}$ em MD (utilizando $2 \%$ de glicose como fonte de carbono). Depois, as células foram diluídas na proporção de 1:10 em meio YPS e cultivadas por outras 48 h. Todos os cultivos 
foram realizados em duplicata. Na seqüência, a enzima heteróloga presente no sobrenadante, a enzima retida no espaço periplásmico e a fração intracelular da enzima foram separadas de acordo com o método descrito por Rouwenhorst et al. (1988). A liberação da fração periplásmica foi induzida pela suspensão das células em $10 \mathrm{~mL}$ do tampão de liberação (tampão fosfato $50 \mathrm{mM}, \mathrm{pH}$ 7, 2-mercaptoetanol $10 \mathrm{mM}$, ditiotreitol $10 \mathrm{mM} \mathrm{e} \mathrm{MgCl}_{2}$ ). A fração intracelular foi liberada incubando as células, das quais já tinha sido extraída a fração periplásmica, em tampão fosfato $100 \mathrm{mM} \mathrm{pH} 7$, contendo $2 \mathrm{mM}$ de $\mathrm{MgCl}_{2}$, DTT 2\%, e $5 \%$ de coquetel de inibidores de protease (Produto no. P8215, Sigma, USA). Pérolas de vidro $(425-600 \mu \mathrm{m})$ foram adicionadas e o rompimento total das células foi realizado agitando a mistura em vórtex por 5 períodos de 1 minuto, sendo que entre cada dois períodos, a amostra era incubada em gelo por 1 minuto. Os debris celulares foram separados por centrifugação e o sobrenadante foi utilizado como contendo a fração intracelular da proteína heteróloga.

A atividade de GOX foi determinada espectrofotometricamente nessas três frações, relativas a uma curva padrão de absorbância versus atividade de enzima, pelo método da redução da o-dianisidina (Malherbe et al., 2003). O conteúdo de proteína em todas as frações foi medido pelo método de Bradford (produto B6916, Sigma, EUA), utilizando albumina bovina como padrão, de acordo com as instruções do fabricante. A biomassa seca de cada amostra de $5 \mathrm{~mL}$ foi determinada para cada frasco de cultivo, utilizando-se filtração da suspensão celular em membranas de 0,45 $\mu \mathrm{m}$ e posterior secagem em forno de microondas ( $180 \mathrm{~W}, 15 \mathrm{~min}$ ) (Olsson e Nielsen, 1997).

\subsection{Análise de glicosilação da GOX}

A glicose oxidase expressada pelas seis diferentes construções de $K$. marxianus e $K$. lactis (Tabela 4.2) foi analisada em relação ao grau de glicosilação nas frações do sobrenadante e periplásmica. Para tal, o sobrenadante e a fração periplásmica foram concentrados em ultrafiltros de corte $10 \mathrm{kDa}$ (Millipore, EUA). Para desglicosilar GOX, $15 \mu \mathrm{g}$ da proteína foram desnaturados por incubação por 5 
minutos a $100{ }^{\circ} \mathrm{C}$ em $10 \mu \mathrm{L}$ de reação que continha SDS a 0,5\% e 2-mercaptoetanol a $40 \mathrm{mM}$. Após o resfriamento, foram adicionados Tergitol NP-40, tampão fosfato $\mathrm{pH}$ 7,5 e PNGase $F$ (New England Biolabs, EUA) às respectivas concentrações de 1\%, $50 \mathrm{mM}$ e $5 \mathrm{U} / \mu \mathrm{L}$, em um volume final de reação de $20 \mu \mathrm{L}$. A mistura foi incubada por 1 hora a $37^{\circ} \mathrm{C}$. Os padrões de migração das formas glicosilada e desglicosilada da GOX foram comparados em géis de SDS-PAGE a 10\%, corados com coomassie blue, conforme descrito por Laemmli et al. (1970).

\subsection{Caracterização bioquímica da GOX}

A enzima sintetizada pelos transformantes de cada espécie, tanto $K$. lactis quanto $K$. marxianus, que exibiram maior atividade enzimática por massa de células nas frações sobrenadante e periplásmica, foram sujeitas à caracterização bioquímica, na qual o $\mathrm{pH}$ de atividade ótima e a estabilidade a diferentes $\mathrm{pHs} \mathrm{e}$ temperaturas foram estudados. A atividade de GOX foi determinada nos seguintes valores de $\mathrm{pH}: 3$, 4, 5 (tampão acetato $50 \mathrm{mM}$ ), 6, 7, 8 (tampão HEPES 50 mM), 9, 10, 11, 12 (tampão Tris $50 \mathrm{mM}$ ). Em cada tampão, foram adicionados glicose a uma concentração final de 100 mM, 2 U de peroxidase (Tipo II, Sigma, EUA) e dihidrocloreto de o-dianisidina para uma concentração final de $100 \mu \mathrm{M}$. A estabilidade térmica foi determinada durante quatro horas de incubação a $37{ }^{\circ} \mathrm{C}, 55^{\circ} \mathrm{C}$ e $60{ }^{\circ} \mathrm{C}$. As amostras foram retiradas nos tempos 0, 1, 2 e 4 horas e a atividade da enzima foi determinada imediatamente. A estabilidade ao $\mathrm{pH}$ foi determinada após 2 horas de incubação da enzima a $37{ }^{\circ} \mathrm{C}$ nos tampões (de pH 3 a 12) mencionados acima. Para a determinação da constante de Michaelis aparente, relativa ao substrato glicose ( $\mathrm{K}_{M}$ (app)), as frações do sobrenadante e periplásmica foram purificadas em uma coluna de gel permeação contendo a matriz Sephacryl S-300-HR, a fim de se eliminar eventuais interferentes. As amostras foram eluídas a $0,5 \mathrm{~mL} / \mathrm{min}$ em tampão citrato $50 \mathrm{mM}\left(\mathrm{pH}\right.$ 4,8). $\mathrm{K}_{\mathrm{M}}$ (app) foi determinado com a medição do incremento da absorbância por minuto, incubando a enzima com tampão citrato-fosfato $50 \mathrm{mM} \mathrm{pH}$ 4,5, $2 \mathrm{U}$ de peroxidase, $100 \mu \mathrm{M}$ de di-hidrocloreto de o-dianisidina e glicose nas seguintes concentrações: 2 mM, 5 mM, 10 mM, 15 mM, 20 mM, 30 mM, 50 mM, 75 
$\mathrm{mM}, 100 \mathrm{mM}$. Todos os ensaios bioquímicos foram também executados com uma GOX comercial obtida de A. niger (G6125, Sigma, EUA), considerada neste trabalho como padrão.

\section{Resultados e Discussão}

\subsection{Níveis de expressão de GOX}

No presente estudo foi possível detectar atividade de GOX em todas as construções, apesar de que, em uma delas (Km1), a atividade de GOX se mostrou muito baixa em relação às outras (Tabela 4.3). Em todos os casos, a grande maioria da enzima ( $>80 \%$ ) foi secretada (Tabela 4.4 ), tanto para o espaço periplásmico, quanto para o sobrenadante. $O$ uso de elementos de $S$. cerevisiae para promover a expressão de GOX acarretou em níveis de expressão maiores em $K$. lactis que em K. marxianus. Essa observação está de acordo com o que foi previamente observado por Bergkamp et al. (1992, 1993), os quais observaram uma expressão de alfa-galactosidase recombinante muito maior em K. lactis CBS 2359 (90 mg/L) que em K. marxianus CBS 6556 (2 mg/L), quando utilizaram os promotores GLC7 ou $P G K$, ambos de $S$. cerevisiae. Como o nível de expressão de GOX na construção Km1 foi tão baixo, não foi possível verificar se o sinal de secreção $k 1$ de $K$. lactis funciona satisfatoriamente em $K$. marxianus.

Um grande aumento nos níveis de GOX heteróloga foi obtido em $K$. marxianus quando o promotor e o sinal de secreção homólogos INU1 foram utilizados para promover a expressão do gene, quando comparado com o uso do promotor de $S$. cerevisiae e sinal de secreção de $K$. lactis. Esse dado também corrobora o observado por Bergkamp et al. (1993), que obtiveram $153 \mathrm{mg} / \mathrm{L}$ de alfagalactosidase heteróloga (incluindo as frações periplásmica e do sobrenadante) em K. marxianus, utilizando o promotor e sinal de secreção INU1, comparados aos 2 $\mathrm{mg} / \mathrm{L}$ produzidos com os elementos de $\mathrm{S}$. cerevisiae já mencionados acima. Esses autores estimaram, nos seus estudos, o número de cópias do plasmídeo de expressão como sendo 25 . Contudo, esse nível de expressão de alfa-galactosidase 
mais alto obtido não pode ser explicado exclusivamente pelo número de cópias (o nível de expressão aumentou 75 vezes em relação à situação anteriormente descrita) e também deve ser causado pela estabilidade do plasmídeo e a força do promotor no hospedeiro. Vale ressaltar que a quantidade de proteína heteróloga produzida no presente trabalho é similar ao que foi obtido no trabalho de Bergkamp et al. (1993). Não foi determinada a quantidade de glicose oxidase em mg/L, mas se assumirmos uma conversão de $80-172 \mathrm{U} / \mathrm{mg}$ de proteína (Wong et al., 2008), podese estimar que a produção de glicose oxidase extracelular na construção Km2 esteve entre 90 a 194 mg/L. Da mesma maneira, Bergkamp et al. (1993) não mediram a alfa-galactosidase em $\mathrm{mg} / \mathrm{L}$, mas os valores de concentração publicados foram estimados utilizando um fator de conversão, que no caso foi de $100 \mathrm{U} / \mathrm{mg}$ (Bergkamp et al., 1992).

Tabela 4.3. Produção heteróloga de GOX no sobrenadante, periplasma e intracelular nas diferentes construções de $K$. marxianus e $K$. lactis.

\begin{tabular}{|c|c|c|c|c|c|c|c|c|}
\hline \multirow{3}{*}{$\begin{array}{l}\text { Cons- } \\
\text { tru- } \\
\text { ção }^{(a)}\end{array}$} & \multirow{3}{*}{$\begin{array}{c}\text { Biomassa } \\
\text { Final }^{(\mathbf{b})} \\
(\mathrm{gMS} / \mathrm{L})\end{array}$} & \multicolumn{7}{|c|}{ Atividade de GOX ${ }^{(\mathrm{c})}$} \\
\hline & & \multicolumn{2}{|c|}{ Sobrenadante } & \multicolumn{2}{|c|}{ Periplasma } & \multicolumn{2}{|c|}{ Intracelular } & Total \\
\hline & & $\mathrm{U} / \mathrm{mgProt}$ & U/gMS & U/mgProt & U/gMS & U/mgProt & U/gMS & U/gMS \\
\hline $\mathrm{Km} 1$ & $7,4 \pm 0,3$ & $0,3 \pm 0,1$ & $0,5 \pm 0,1$ & $2,4 \pm 0,1$ & $1,9 \pm 0,1$ & $0,03 \pm 0,02$ & $4,0 \pm 1,4$ & $7,4 \pm 2,5$ \\
\hline $\mathrm{Km} 2$ & $12,1 \pm 0,2$ & $251 \pm 72$ & $407 \pm 16$ & $180 \pm 24$ & $1145 \pm 35$ & $1,3 \pm 0,2$ & $171 \pm 44$ & $1722 \pm 62$ \\
\hline $\mathrm{Km} 3$ & $12,0 \pm 0,1$ & $171 \pm 44$ & $255 \pm 1$ & $187 \pm 8$ & $850 \pm 70$ & $2,4 \pm 0,3$ & $291 \pm 27$ & $1395 \pm 42$ \\
\hline $\mathrm{KI} 1$ & $9,9 \pm 0,2$ & $40 \pm 3$ & $161 \pm 17$ & $16 \pm 1$ & $13 \pm 1$ & $0,3 \pm 0,1$ & $31 \pm 2$ & $205 \pm 16$ \\
\hline $\mathrm{KI} 2$ & $11,2 \pm 0,0$ & $32 \pm 1$ & $94 \pm 6$ & $64 \pm 5$ & $49 \pm 8$ & $0,1 \pm 0,0$ & $16 \pm 3$ & $158 \pm 17$ \\
\hline $\mathrm{KI} 3$ & $9,6 \pm 0,2$ & $29 \pm 1$ & $94 \pm 12$ & $76 \pm 4$ & $64 \pm 0$ & $0,1 \pm 0,0$ & $13 \pm 1$ & $170 \pm 11$ \\
\hline
\end{tabular}

(a) ver seção de Materiais e Métodos, Tabela 4.1 e Figura 4.1. para descrição das construções genéticas;

(b) ver seção de Materiais e Métodos para descrição das condições de cultivo;

(c) fracionamento celular realizado de acordo com Rouwenhorst et al. (1988).

Tabela 4.4. Distribuição subcelular de GOX heteróloga nas diferentes construções de K. marxianus e K. lactis.

\begin{tabular}{lccc}
\hline Construção $^{\text {(a) }}$ & \multicolumn{3}{c}{ Atividade de GOX por gMS em cada fração relativa à atividade total } \\
\cline { 2 - 4 } & Sobrenadante & Periplasma & Intracelular \\
\hline $\mathrm{Km} 1$ & $9 \% \pm 3 \%$ & $31 \% \pm 8 \%$ & $62 \% \pm 11 \%$ \\
$\mathrm{Km} 2$ & $23 \% \pm 2 \%$ & $67 \% \pm 1 \%$ & $10 \% \pm 3 \%$ \\
$\mathrm{Km} 3$ & $19 \% \pm 1 \%$ & $61 \% \pm 3 \%$ & $21 \% \pm 2 \%$ \\
$\mathrm{KI} 1$ & $79 \% \pm 2 \%$ & $6 \% \pm 0 \%$ & $16 \% \pm 2 \%$ \\
$\mathrm{KI} 2$ & $60 \% \pm 2 \%$ & $31 \% \pm 2 \%$ & $10 \% \pm 0 \%$ \\
$\mathrm{Kl} 3$ & $50 \% \pm 3 \%$ & $38 \% \pm 3 \%$ & $10 \% \pm 3 \%$ \\
\hline
\end{tabular}

(a) ver seção de Materiais e Métodos, Tabela 4.1 e Figura 4.1. para descrição das construções genéticas;

(b) ver seção de Materiais e Métodos para descrição das condições de cultivo;

(c) fracionamento celular realizado de acordo com Rouwenhorst et al. (1988).

O aumento da expressão de GOX quando utilizados promotor e sinal de secreção INU1 foi exclusivo para K. marxianus, já que nas construções de $K$. lactis 
que utilizaram esse sistema (KI2 e $\mathrm{KI} 3$ ), os níveis totais de GOX produzida foram ligeiramente inferiores que os níveis obtidos na construção $\mathrm{Kl} 1$, que utilizou $\mathrm{O}$ promotor $P G K$ de $S$. cerevisiae e sinal de secreção $k 1$ de $K$. lactis (Tabela 4.3).

Quando ambos sistemas baseados em INU1 são comparados em $K$. marxianus, pode-se notar que a quantidade de GOX produzida está ao redor do mesmo nível, ligeiramente superior na construção epissomal (Km2) que na construção integrativa (Km3) (Tabela 4.3). Embora a integração ocorra normalmente em simples cópia e os plasmídeos epissomais sejam capazes de se multiplicar de forma autônoma no citoplasma, esta semelhança nos níveis de expressão de GOX pode estar relacionada ao efeito de um maior número de cópias de pSPINGOX em Km2 (em relação ao número de cópias integradas no caso de Km3), combinado com uma perda plasmidial ao longo dos cultivos, o que não ocorre no caso da construção integrativa. De acordo com os estudos realizados sobre a estabilidade dos plasmídeos, a totalidade das células transformadas seria perdida após aproximadamente 38 gerações, que é equivalente ao tempo de cultivo de $48 \mathrm{~h}$.

A Tabela 4.5 mostra uma visão geral dos sistemas desenvolvidos para a expressão heteróloga de GOX em diferentes microrganismos. Uma comparação direta entre os diferentes sistemas de expressão é difícil, devido às diferentes estratégias de cultivo utilizadas em cada caso. Levando-se isso em consideração, os níveis de atividade de GOX alcançados neste trabalho com K. marxianus estão num patamar médio-inferior, se considerarmos os níveis mais altos (30000 U/g MS, assumindo uma concentração final de biomassa de $15 \mathrm{~g} / \mathrm{L}$, Park et al., 2000) e o mais baixo (27,9 U/g MS, Hellmuth et al., 1995) publicados (Tabela 4.5). No entanto, o objetivo do presente trabalho não foi o de otimizar os níveis de expressão de GOX, havendo, portanto, certamente espaço para aumentar estes níveis com as construções aqui descritas, caso desejado, em trabalhos futuros. 
Tabela 4.5. Visão geral dos diferentes sistemas microbianos empregados para a expressão heteróloga da glicose oxidase de $A$. niger.

\begin{tabular}{|c|c|c|c|c|c|c|c|c|c|c|}
\hline $\begin{array}{c}\text { GOX } \\
\text { de }\end{array}$ & $\begin{array}{c}\text { Expressada } \\
\text { em }\end{array}$ & Sistema & $\begin{array}{l}\text { Promo- } \\
\text { tor }\end{array}$ & $\begin{array}{l}\text { Sinal de } \\
\text { secreção }\end{array}$ & $\begin{array}{l}\text { Nível } \\
\text { Extra- } \\
\text { celular }\end{array}$ & Meio de cultivo & $\begin{array}{c}\text { Cultivo } \\
\text { em }\end{array}$ & $\begin{array}{l}\text { Processo } \\
\text { otimizado? }\end{array}$ & $\begin{array}{l}\text { Estudo sobre } \\
\text { glicosilação? }\end{array}$ & Referência \\
\hline $\begin{array}{l}\text { A. } \\
\text { niger }\end{array}$ & $\begin{array}{l}\text { Hansenula } \\
\text { polymorpha }\end{array}$ & Epissomal & MOX1 & $\begin{array}{l}\text { A. oryzae } \\
\alpha \text {-amilase }\end{array}$ & NP & $\begin{array}{l}\text { CM-LEU + 2\% GLC } \\
\text { (12h, inóculo); } \\
\text { Complexo + } 2 \% \\
\text { metanol (36h, } \\
\text { cultivo) }\end{array}$ & $\begin{array}{l}\text { Frasco } \\
\text { agitado }\end{array}$ & Não & $\begin{array}{l}\text { GOX de } H . \\
\text { polymorpha }(200 \\
\text { kDa). De } S . \\
\text { cerevisiae }(220 \\
\text { kDa), De } A . \text { niger } \\
(160 \mathrm{kDa}) .\end{array}$ & $\begin{array}{l}\text { Kim et al. } \\
(2004)\end{array}$ \\
\hline $\begin{array}{l}\text { A. } \\
\text { niger }\end{array}$ & $\begin{array}{l}\text { Hansenula } \\
\text { polymorpha }\end{array}$ & Epissomal & MOX1 & $\begin{array}{l}\text { A. oryzae } \\
\alpha \text {-amilase }\end{array}$ & NP & $\begin{array}{l}\text { Complexo + } 2 \% \\
\text { GLC (12h, inóculo); } \\
\text { Complexo + } 2 \% \\
\text { metanol (36h, } \\
\text { cultivo) }\end{array}$ & $\begin{array}{l}\text { Frasco } \\
\text { agitado }\end{array}$ & Não & $\begin{array}{l}\text { GOX de } H \text {. } \\
\text { polymorpha ficou } \\
\text { menos glicosilada } \\
\text { quando a levedura } \\
\text { foi cultivada em } \\
\text { meio contendo } \\
\text { sorbitol (aprox. } 190 \\
\text { kDa). }\end{array}$ & $\begin{array}{l}\text { Kim et al. } \\
(2007)\end{array}$ \\
\hline $\begin{array}{l}\text { A. } \\
\text { niger }\end{array}$ & $\begin{array}{l}\text { Mucor } \\
\text { circinelloide } \\
s\end{array}$ & Epissomal & $\begin{array}{l}\text { A. } \\
\text { nidulans } \\
\text { gpd1 }\end{array}$ & $\begin{array}{l}\text { A. niger } \\
\text { gox }\end{array}$ & $\begin{array}{l}\text { Presente, } \\
\text { mas não } \\
\text { quantifi- } \\
\text { cado }\end{array}$ & $\begin{array}{l}\text { Complexo + } 2 \% \\
\text { GLC (cultivo) }\end{array}$ & Biorreator & Não & Não & $\begin{array}{l}\text { Wolff e } \\
\text { Arnau } \\
(2002)\end{array}$ \\
\hline $\begin{array}{l}\text { A. } \\
\text { niger }\end{array}$ & A. niger & Epissomal & $\begin{array}{l}\text { A. } \\
\text { nidulans } \\
\text { gpd1 }\end{array}$ & $\begin{array}{l}\text { A. oryzae } \\
\alpha \text {-amilase }\end{array}$ & $\begin{array}{l}27.9 \\
\text { U/gMS }\end{array}$ & $\begin{array}{l}\text { Mínimo }+0.2 \% \\
\text { extrato de levedura } \\
+ \text { GLC } 8 \%(60 \mathrm{~h}, \\
\text { cultivo) }\end{array}$ & Biorreator & $\begin{array}{l}\text { Sim. De frascos } \\
\text { agitados para } \\
\text { biorreator. A } \\
\text { composição do } \\
\text { meio também foi } \\
\text { otimizada }\end{array}$ & Não & $\begin{array}{l}\text { Hellmuth et } \\
\text { al. (1995) }\end{array}$ \\
\hline $\begin{array}{l}\text { A. } \\
\text { niger }\end{array}$ & $\begin{array}{l}\text { S. } \\
\text { cerevisiae }\end{array}$ & Epissomal & $\begin{array}{l}\text { GAL1, } \\
\text { GAL10, } \\
\text { GPD, } \\
\text { AG } \\
\text { (ADH2 } \\
\text { UAS:: } \\
\text { GPD } \\
\text { TATA) }\end{array}$ & $\begin{array}{l}\text { Parte do } \\
\text { A. niger } \\
\text { gox -40 bp } \\
\text { montante } \\
\text { do códon } \\
\text { início }\end{array}$ & $460 \mathrm{U} / \mathrm{mL}$ & $\begin{array}{l}\text { CM-URA + } 2 \% \text { GLC } \\
(24 \mathrm{~h}, \text { inóculo); } \\
\text { complexo }+3 \% \\
\text { xarope de milho } \\
\text { ( } 72 \mathrm{~h}, \text { cultivo) }\end{array}$ & $\begin{array}{l}\text { Frasco } \\
\text { agitado }\end{array}$ & $\begin{array}{l}\text { Sim. GLC e } \\
\text { xarope de milho } \\
\text { foram testados. } \\
\text { Mutagênese em } \\
\text { UV foi utilizada } \\
\text { para aumentar a } \\
\text { produção de } \\
\text { GOX. }\end{array}$ & $\begin{array}{l}\text { GOX de } S \text {. } \\
\text { cerevisiae: } 220 \text { kDa. }\end{array}$ & $\begin{array}{l}\text { Park et al. } \\
(2000)\end{array}$ \\
\hline $\begin{array}{l}\text { A. } \\
\text { niger }\end{array}$ & $\begin{array}{l}\text { S. } \\
\text { cerevisiae }\end{array}$ & $\begin{array}{l}\text { Epissomal } \\
\text { e } \\
\text { Integrativo }\end{array}$ & PGK1 & $\begin{array}{l}\text { S. } \\
\text { cerevisiae } \\
M F \alpha\end{array}$ & $90 \mathrm{U} / \mathrm{mL}$ & $\begin{array}{l}\text { CM-URA + } 2 \% \text { GLC } \\
(24 \mathrm{~h}, \text { cultivo })\end{array}$ & $\begin{array}{l}\text { Frasco } \\
\text { agitado }\end{array}$ & Não. & Não & $\begin{array}{l}\text { Malherbe et } \\
\text { al. (2003) }\end{array}$ \\
\hline
\end{tabular}




\begin{tabular}{|c|c|c|c|c|c|c|c|c|c|c|}
\hline $\begin{array}{c}\text { GoX } \\
\text { de }\end{array}$ & $\begin{array}{c}\text { Expressada } \\
\text { em }\end{array}$ & Sistema & $\begin{array}{l}\text { Promo- } \\
\text { tor }\end{array}$ & $\begin{array}{l}\text { Sinal de } \\
\text { secreção }\end{array}$ & $\begin{array}{l}\text { Nível } \\
\text { Extra- } \\
\text { celular }\end{array}$ & Meio de cultivo & $\begin{array}{l}\text { Cultivo } \\
\text { em }\end{array}$ & $\begin{array}{l}\text { Processo } \\
\text { otimizado? }\end{array}$ & $\begin{array}{l}\text { Estudo sobre } \\
\text { glicosilação? }\end{array}$ & Referência \\
\hline $\begin{array}{l}\text { A. } \\
\text { niger }\end{array}$ & A. nidulans & Integrativo & $x \ln B$ & $\begin{array}{l}\text { A. niger } \\
\text { gox }\end{array}$ & $2.3 \mathrm{U} / \mathrm{mL}$ & $\begin{array}{l}\text { Mínimo para } \\
\text { Aspergillus } \\
\text { (Pontecorvo et al., } \\
\text { 1953). Xilose como } \\
\text { indutor.(cultivo) }\end{array}$ & Biorreator & $\begin{array}{l}\text { Sim. Investigado } \\
\text { o melhor pH e a } \\
\text { melhor fonte de } \\
\text { carbono. }\end{array}$ & Não & $\begin{array}{l}\text { Luque et al. } \\
(2004)\end{array}$ \\
\hline $\begin{array}{l}\text { A. } \\
\text { niger }\end{array}$ & $\begin{array}{l}H . \\
\text { polymorpha }\end{array}$ & Epissomal & $\begin{array}{l}P M A 1 \\
\text { and } \\
\text { MOX }\end{array}$ & $\begin{array}{l}\text { S. } \\
\text { cerevisiae } \\
M F \alpha\end{array}$ & $\begin{array}{l}298 \\
\text { U/gMS }\end{array}$ & $\begin{array}{l}\text { Fed batch usando } \\
\text { meio mínimo DW } \\
\text { (Hodgkins et al., } \\
\text { 1993) + } 2 \% \text { GLC. } \\
\text { Alimentação com } \\
50 \% \text { da fonte de } \\
\text { carbono }\end{array}$ & Biorreator & $\begin{array}{l}\text { Sim. Realizada } \\
\text { batelada } \\
\text { alimentada para } \\
\text { alta densidade de } \\
\text { células. O pH foi } \\
\text { otizado em } 5.0 \mathrm{e} \\
\text { a temperatura em } \\
30^{\circ} \mathrm{C}\end{array}$ & Não & $\begin{array}{l}\text { Cox et al. } \\
(2000)\end{array}$ \\
\hline $\begin{array}{l}\text { A. } \\
\text { niger }\end{array}$ & $\begin{array}{l}\text { K. } \\
\text { marxianus }\end{array}$ & Epissomal & INU1 & $\begin{array}{l}\text { K. } \\
\text { marxianus } \\
\text { INU1 }\end{array}$ & $\begin{array}{l}1316 \\
\text { U/gMS }\end{array}$ & $\begin{array}{l}\text { Mínimo + } 2 \% \text { GLC } \\
(24 \mathrm{~h} \text {, inóculo); } \\
\text { complexo }+2 \% \text { SUC } \\
\text { ( } 36 \mathrm{~h} \text {, cultivo) }\end{array}$ & $\begin{array}{l}\text { Frasco } \\
\text { agitado }\end{array}$ & Não & $\begin{array}{l}\text { Sim. Massa da } \\
\text { GOX: aprox. } 200 \\
\text { kDa. }\end{array}$ & $\begin{array}{l}\text { Este } \\
\text { trabalho }\end{array}$ \\
\hline $\begin{array}{l}\text { A. } \\
\text { niger }\end{array}$ & K. lactis & Epissomal & $P G K$ & $\begin{array}{l}\text { K. lactis } \mathrm{k}_{\mathrm{l}} \\
\text { killer } \\
\text { protein }\end{array}$ & $\begin{array}{l}174 \\
\text { U/gMS }\end{array}$ & $\begin{array}{l}\text { Mínimo + } 2 \% \text { GLC } \\
(24 \mathrm{~h} \text {, inóculo); } \\
\text { complexo }+2 \% \text { SUC } \\
\text { ( } 36 \mathrm{~h} \text {, cultivo) }\end{array}$ & $\begin{array}{l}\text { Frasco } \\
\text { agitado }\end{array}$ & Não & $\begin{array}{l}\text { Sim. Massa da } \\
\text { GOX: aprox. } 300 \\
\text { kDa. }\end{array}$ & $\begin{array}{l}\text { Este } \\
\text { trabalho }\end{array}$ \\
\hline
\end{tabular}




\subsection{Caracterização bioquímica da GOX heteróloga}

A caracterização bioquímica da GOX realizada neste trabalho, em termos da estimativa do peso molecular utilizando géis desnaturantes (Figura 4.4), da atividade em diferentes valores de $\mathrm{pH}$ e da estabilidade frente a diferentes valores de $\mathrm{pH}$ e temperatura (Figuras 4.2 e 4.3) e em termos da constante de Michaelis-Menten aparente para glicose (Tabela 4.6) confirma que ambas as leveduras são capazes de expressar e secretar a proteína heteróloga esperada. $\mathrm{O} \mathrm{pH}$ em que a atividade de GOX é máxima está entre 4 e 6 para todos os casos investigados (Figura 4.2A). A enzima produzida por $K$. marxianus apresentou um perfil de atividade versus $\mathrm{pH}$ mais próximo ao da GOX padrão na região de $\mathrm{pH}$ entre 3 e 7, quando comparada com a GOX de K. lactis. O pH ótimo determinado por Zia et al. (2007a) foi de 5,5. $\mathrm{Em}$ pH alcalino, a GOX padrão se mostrou mais ativa que as heterólogas. A GOX secretada por $K$. marxianus é apenas parcialmente afetada em pH alcalino (Figura 4.2B), já que após 2 horas de exposição a essa condição, a atividade pode ser restaurada incubando a enzima em tampão usado para determinação de atividade de GOX (citrato-fosfato $100 \mathrm{mM} \mathrm{pH} \mathrm{4,5).} \mathrm{A} \mathrm{enzima} \mathrm{secretada} \mathrm{por} \mathrm{K.} \mathrm{lactis} \mathrm{é}$ diferente, pois apenas uma pequena parcela da sua atividade original foi recuperada sob tais condições. Dessa forma, o fato de as enzimas produzidas em $K$. lactis estarem mais glicosiladas pode ter provocado uma mudança conformacional suficiente para modificar a atividade de $\mathrm{GOX} \mathrm{em} \mathrm{pH}$ alcalino. Não obstante, é possível afirmar que, em geral, o comportamento de ambas enzimas heterólogas é muito similar à enzima padrão, principalmente entre $\mathrm{pH} 4$ e 8.
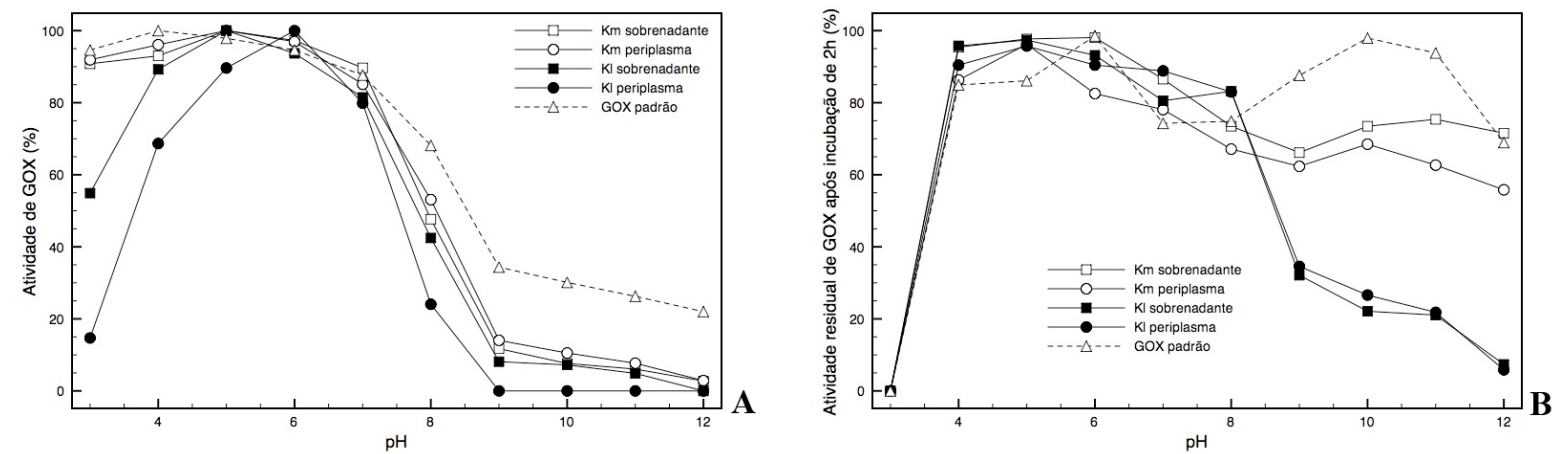

Figura 4.2. Atividade e estabilidade a diferentes $\mathrm{pHs}$. (A) A atividade de GOX foi determinada em $\mathrm{pH}$ de 3 a 12; e (B) atividade residual de GOX determinada depois de 2 horas de incubação da enzima a $37{ }^{\circ} \mathrm{C}$ na mesma faixa de $\mathrm{pH}$. Cada ponto é a média de uma duplicata. $\mathrm{Km}$ sobrenadante e $\mathrm{Km}$ periplasma: GOX produzida pela construção $\mathrm{Km} 2$. KI sobrenadante e $\mathrm{KI}$ periplasma: GOX produzida pela construção KI1. GOX padrão: GOX comercial de A. niger (Produto B6916, Sigma, EUA). 
Em termos de estabilidade frente à temperatura, todas as enzimas apresentaram comportamento similar. As enzimas mantiveram-se estáveis após 4 horas de incubação a $37^{\circ} \mathrm{C}$. Já nas temperaturas de $55^{\circ} \mathrm{C}$ e $60^{\circ} \mathrm{C}$, principalmente nesta última, a estabilidade foi drasticamente afetada (Figura 4.3). Um padrão de inativação térmica similar foi obtido por Gouda et al. (2003), os quais observaram perdas significativas de atividade a temperaturas maiores que $50{ }^{\circ} \mathrm{C}$.
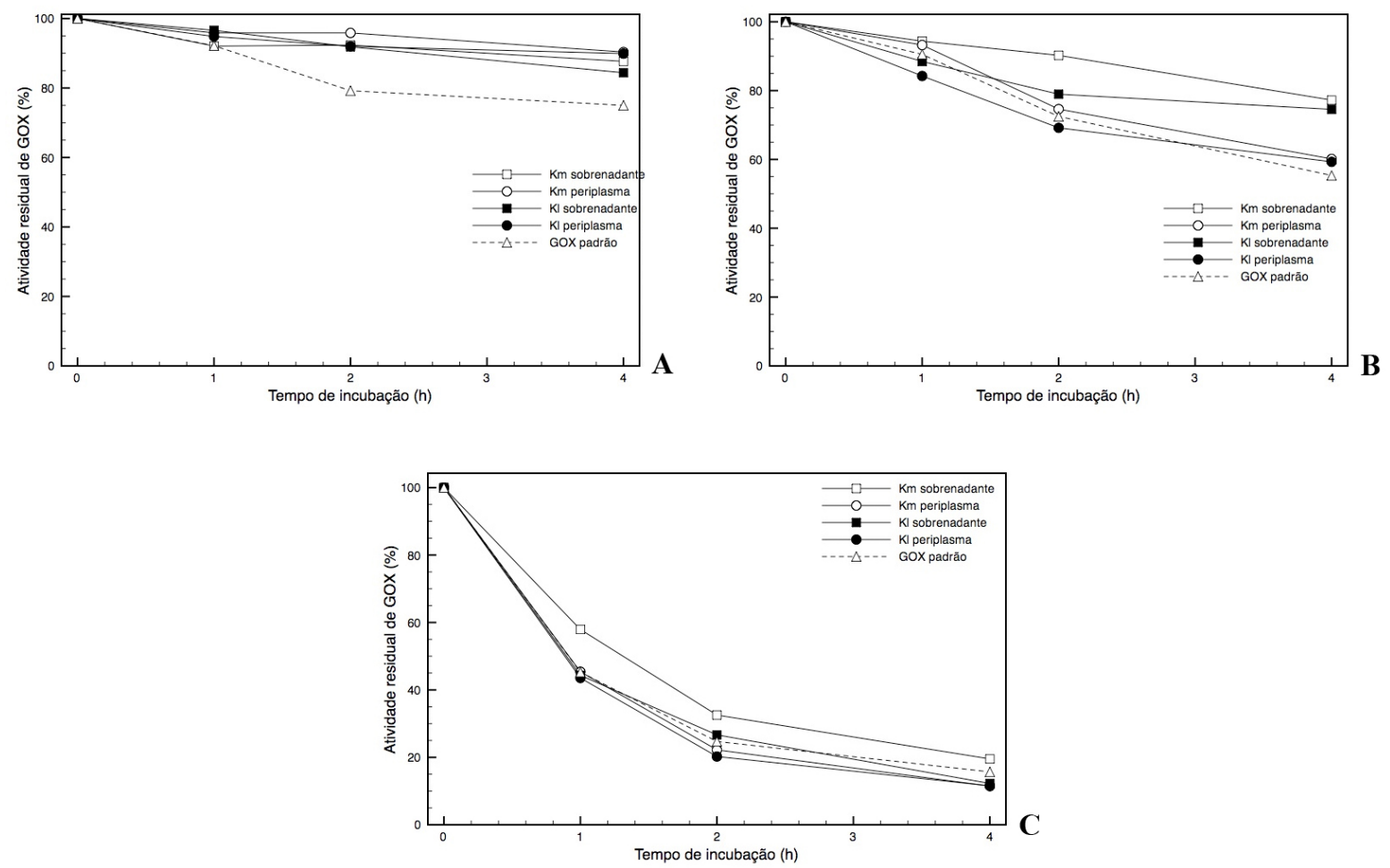

Figura 4.3. Estabilidade de GOX a diferentes temperaturas. A atividade residual de GOX foi medida após manter a enzima incubada a (A) $37^{\circ} \mathrm{C}$; (B) $55^{\circ} \mathrm{C}$; (C) $60^{\circ} \mathrm{C}$. Cada ponto é a média de uma duplicata. $\mathrm{Km}$ sobrenadante e $\mathrm{Km}$ periplasma: GOX produzida pela construção $\mathrm{Km} 2$. $\mathrm{KI}$ sobrenadante e KI periplasma: GOX produzida pela construção KI1. GOX padrão: GOX comercial de A. niger (Produto B6916, Sigma, EUA).

A constante de Michaelis-Menten aparente para glicose $\left(\mathrm{K}_{\mathrm{M}(\mathrm{app})}\right)$ foi similar em todos os casos estudados (Tabela 4.6) e próxima ao valor obtido com a GOX padrão, a qual pode ser considerada muito pura, como se pode verificar nos géis da Figura 4.4. Não existe um consenso na literatura em relação ao $\mathrm{K}_{\mathrm{M}}$ exato da GOX. Wong et al. (2008) revisou vários autores que publicaram valores que variavam entre $33 \mathrm{mM}\left(\right.$ a $25^{\circ} \mathrm{C}$ ) até $248 \mathrm{mM}$ (a $30^{\circ} \mathrm{C}$ ). Zia et al. (2007a) publicaram um valor de $\mathrm{K}_{\mathrm{M}}$ de $2,56 \mathrm{mM}\left(\mathrm{a} 40^{\circ} \mathrm{C}\right.$ ) para GOX produzida por $A$. niger UAF-1. Os mesmos autores obtiveram um $\mathrm{K}_{\mathrm{M}}$ de $28 \mathrm{mM}$ para a enzima produzida por $A$. niger BCG-5, a qual era 
uma linhagem que havia sofrido mutagênese por UV (Zia et al., 2007b). Mirón et al. (2002) estimaram o valor de $18 \mathrm{mM}$ (a $30^{\circ} \mathrm{C}$ ). Kohen et al. (1997) calcularam um $\mathrm{K}_{\mathrm{M}}$ de $28 \mathrm{mM}$ a $25^{\circ} \mathrm{C}$. Essa grande variedade de valores é provavelmente devida às diferentes condições empregadas nos ensaios de atividade.

Tabela 4.6. Valores de KM (app) determinados em relação à glicose pelo método de linearização de Lineweaver-Burk.

\begin{tabular}{lc}
\hline Origem da GOX & $\mathbf{K}_{\mathbf{M} \text { (app) }}$ \\
\hline Km2 sobrenadante & $22,8 \mathrm{mM}$ \\
Km2 periplasma & $17,4 \mathrm{mM}$ \\
KI1 sobrenadante & $24,4 \mathrm{mM}$ \\
KI1 periplasma & $22,6 \mathrm{mM}$ \\
GOX padrão & $16,4 \mathrm{mM}$ \\
\hline
\end{tabular}

Na Figura 4.4 é possível observar que, após a remoção dos carboidratos da GOX heteróloga utilizando PNGase $F$, duas bandas aparecem nos géis correspondentes a $K$. marxianus (indicadas pelas setas, Figuras 4.4A e 4.4B), enquanto apenas uma banda é visível no gel correspondente a $K$. lactis (Figuras 4.4C e 4.4D). Já que apenas uma banda é visível após a desglicosilação da GOX padrão com a mesma PNGase, isso indica que os padroes de glicosilação em $K$. marxianus e $K$. lactis são diferentes. É possível que a GOX produzida em $K$. marxianus possua também O-glicosilações (Strahl-Bolsinger et al., 1999; Lommel e Strahl, 2009) além das $N$-glicosilações, o que não ocorre em $K$. lactis. Outra observação é que a GOX glicosilada em $K$. lactis tem um maior peso molecular que a de K. marxianus, indicando que esta última apresenta uma menor tendência de hiperglicosilar proteínas que aquela, e que, conseqüentemente, essa tendência é menor que em S. cerevisiae (Chiba e Jigami, 2007). Bergkamp et al. (1993) também observaram que o peso molecular de uma alfa-galactosidase expressada em $S$. cerevisiae era maior que o da mesma enzima produzida por $K$. marxianus, o que é devido às glicosilações. A Tabela 4.5 mostra que os níveis de glicosilação de GOX em $K$. marxianus são similares aos observados em $H$. polymorpha, os quais foram os menores observados para GOX heterólogas produzidas em leveduras. Também é possível verificar nos géis que as frações periplásmica e extracelular da GOX apresentam enzimas de peso molecular semelhante em ambas as espécies de leveduras. 

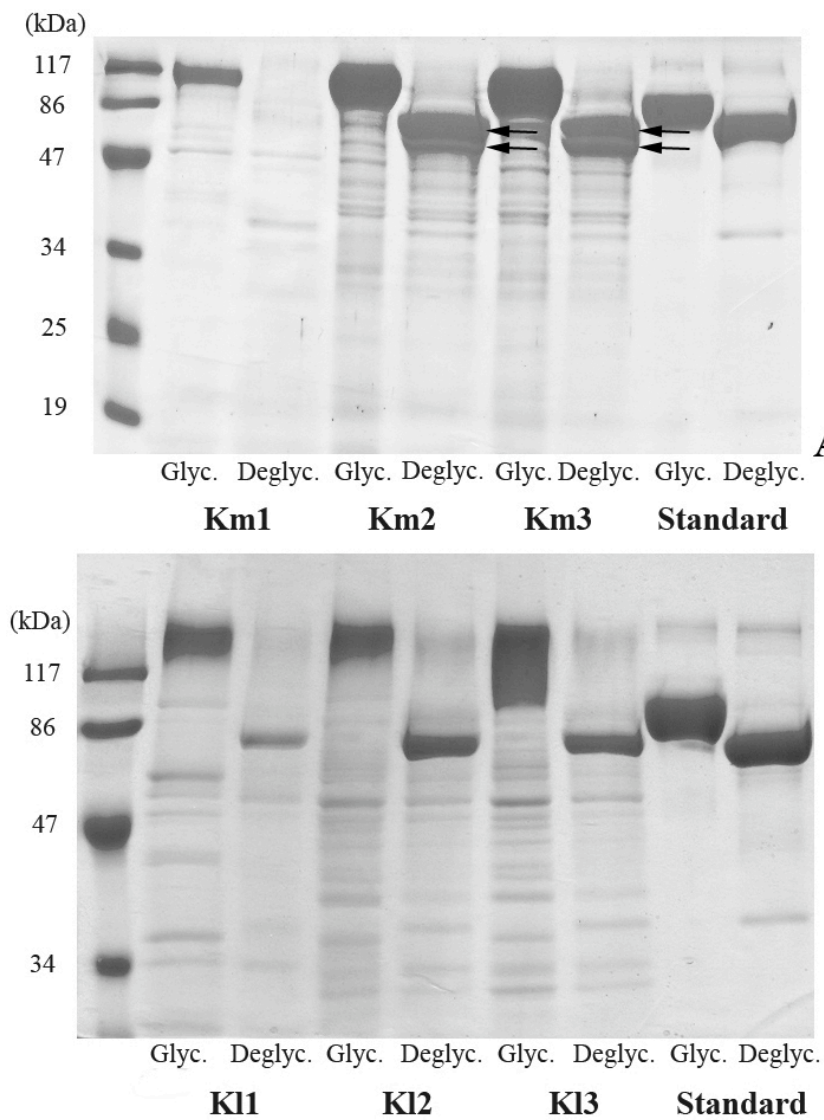

A

19

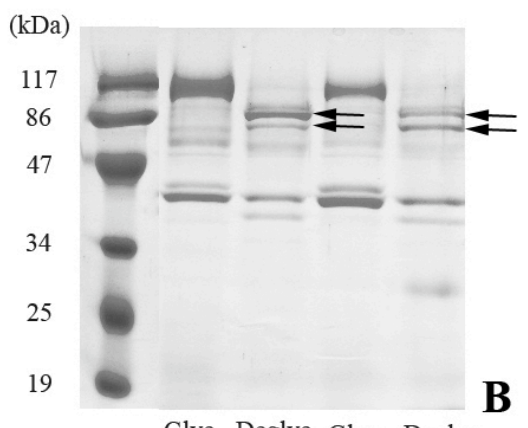

Glyc. Deglyc. Glyc. Deglyc.

$\mathrm{Km} 2 \quad \mathrm{Km} 3$

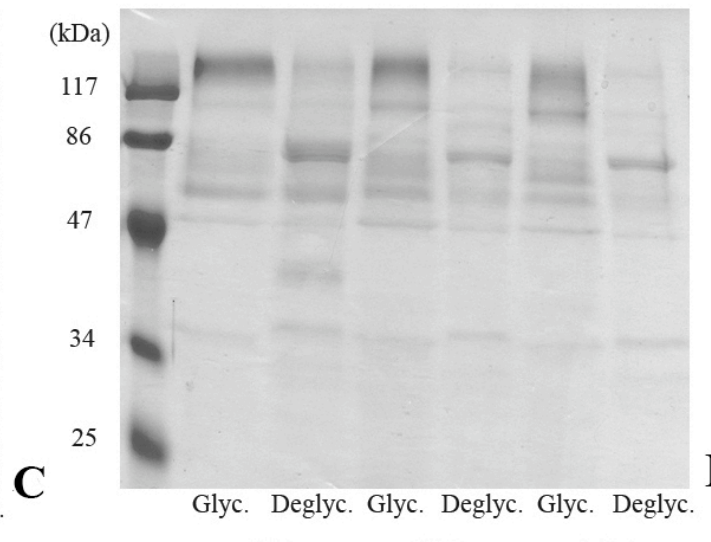

D

$\mathrm{Kl3}$

Figura 4.4. SDS-PAGE corada com coomassie blue para a análise do padrão de glicosilação da GOX expressada em $(A, B) K$. marxianus e $(C, D) K$. lactis. (A) GOX do periplasma de K. marxianus; (B) GOX do sobrenadante do cultivo de K. marxianus; (C) GOX do periplasma de K. lactis; (D) GOX do sobrenadante do cultivo de K. lactis. Glyc: enzima glicosilada. Deglyc: enzima desglicosilada com PNGase $\mathrm{F}$, como descrito nos métodos. Os códigos das construções estão listados na Tabela 4.2. Standard: GOX comercial de A. niger (Produto B6916, Sigma, EUA). As setas indicam as duas bandas resultantes da desglicosilação de GOX expressada em K. marxianus.

As bandas correspondentes à GOX de $K$. lactis são mais difusas que as de $K$. marxianus. Isso se deve à degradação da enzima durante a sua extração do espaço periplásmico. Quando as bandas que correspondem ao sobrenadante dos cultivos de K. marxianus e $K$. lactis (Figuras 4.4B e 4.4D, respectivamente) são comparadas com as bandas que correspondem às amostras do periplasma de $K$. marxianus e $K$. lactis (Figuras 4.4A e 4.4C, respectivamente), pode ser observado que há menor número de proteínas no primeiro caso, quando comparado ao último. Isso se deve provavelmente à liberação de proteínas do periplasma durante o procedimento de extração.

O padrão de glicosilação de uma proteína heteróloga pode ser um critério importante no desenho de um sistema de produção comercial. No caso particular de 
GOX, Kohen et al. (1997) discutiram que a glicosilação não afeta os parâmetros catalíticos da enzima (ligação do substrato e liberação do produto) quando glicose é usada como substrato. Além disso, os autores afirmam que não há evidência que a glicosilação cause uma mudança drástica na estrutura da proteína. As cadeias de polissacarídeos muito provavelmente não interagem com a superfície da proteína ou com seu sítio ativo, devido à sua preferência de solvatação pela água. Os resultados obtidos neste trabalho corroboram essa hipótese. A noção que $K$. marxianus apresenta uma menor tendência de hiperglicosilar uma proteína heteróloga necessita ser confirmada pela expressão de outras proteínas neste organismo e, caso seja confirmada, pode contribuir para tornar este hospedeiro atrativo para a expressão de proteínas terapêuticas.

\section{Conclusões}

A proteína-modelo glicose oxidase (GOX) de Aspergillus niger foi utilizada para avaliar o potencial da levedura $K$. marxianus como hospedeira na produção de proteínas heterólogas. $\mathrm{O}$ uso desta proteína permite comparar os dados obtidos em K. marxianus não somente com $K$. lactis (também estudada neste trabalho), mas também com os variados sistemas de expressão heteróloga de GOX já desenvolvidos e reportados na literatura. Como a GOX possui oito sítios de $\mathrm{N}$ glicosilação, essa enzima torna-se adequada para um estudo comparativo de glicosilação nos sistemas de expressão de $K$. marxianus e $K$. lactis. Para esse propósito, foram construídos dois diferentes sistemas de expressão heteróloga epissomais e um integrativo, contendo elementos genéticos de $S$. cerevisiae, de $K$. lactis e de $K$. marxianus, em diferentes combinações. Esses sistemas de expressão foram utilizados para transformar células de $K$. marxianus e $K$. lactis, a fim de se comparar diretamente os níveis de expressão de GOX em ambas as leveduras. A caracterização bioquímica da enzima secretada, em termos de localização celular, do padrão de glicosilação, da atividade em diferentes $\mathrm{pHs}$, da estabilidade frente a diferentes temperaturas e pHs e da constante de Michaelis-Menten aparente para glicose mostraram que a GOX foi expressada de forma ativa nas duas espécies. O maior valor de GOX secretada foi de $1552 \mathrm{U} / \mathrm{g}$ de biomassa seca de $K$. marxianus 
CBS 6556, utilizando um sistema de expressão epissomal, com promotor, sinal de secreção e terminador do gene homólogo INU1. A expressão promovida com elementos de INU1 resultou em um maior nível de expressão em $K$. marxianus que em $K$. lactis. Esta última apresentou uma maior capacidade de secreção de GOX para o sobrenadante dos cultivos, quando comparada a $K$. marxianus, o que pode indicar que a parede celular deste organismo esteja agindo como uma barreira para a retenção da proteína no periplasma. Em relação à glicosilação, aparentemente a enzima expressada em $K$. marxianus é menos glicosilada que a produzida pela sua congênere. Em suma, este trabalho traz informações importantes sobre o potencial da levedura K. marxianus como hospedeira para a síntese de proteínas heterólogas. Esta levedura deveria ser mais explorada para esta finalidade do que tem sido até o momento, já que possibilitou níveis médios de expressão de uma proteína altamente glicosilada como é a GOX de A. niger, sem que tenha sido realizada uma otimização da produção desta proteína. Além disto, apresentou menor tendência de hiperglicosilação, se comparada à $K$. lactis. 
Capítulo 5

\section{Expressão heteróloga de uma esterase} termofílica na levedura Kluyveromyces

\section{marxianus}

Artigo a ser submetido 


\section{EXPRESSÃO HETERÓLOGA DE UMA ESTERASE TERMOFÍLICA NA LEVEDURA Kluyveromyces marxianus}

Saul Nitsche Rocha, José Abrahão-Neto², María Esperanza Cerdán ${ }^{3}$, Andreas Karoly Gombert $^{1}$ e María Isabel González-Siso ${ }^{3 \S}$

${ }^{1}$ Departamento de Engenharia Química, Universidade de São Paulo, CP 61548, 05424-970, São Paulo-SP, Brasil

2 Faculdade de Ciências Farmacêuticas, Universidade de São Paulo, Av. Prof. Lineu Prestes, 580, bloco 15, 05508-900, São Paulo-SP, Brasil

${ }^{3}$ Departamento de Bioloxía Celular e Molecular, Facultade de Ciencias, Universidade da

Coruña, Campus da Zapateira s/n, 15071-A Coruña, Espanha

$\S$ Autor para corespondência

E-mail:migs@udc.es

FAX: +551130912284

\section{Resumo}

Apesar das propriedades fisiológicas vantajosas para aplicações em bioprocessos, o uso da levedura Kluyveromyces marxianus como hospedeira na produção de proteínas heterólogas vem sendo muito limitado, em contraste à sua congênere $K$. lactis. Além disso, K. marxianus é um organismo termotolerante, característica que pode auxiliar na expressão de enzimas de organismos termófilos. No presente trabalho, uma esterase termofílica de Thermus thermophilus HB27 foi clonada em K. marxianus CBS 6556 e em K. lactis CBS 2359, utilizando três diferentes sistemas de expressão. O objetivo foi avaliar o potencial de $K$. marxianus para expressar uma proteína termofílica e compará-la a K. lactis, um hospedeiro já bem caracterizado para a síntese de proteínas heterólogas. Além disso, foram avaliados os níveis de enzima produzida a partir de cada construção e as propriedades bioquímicas das enzimas expressadas, como atividade e estabilidade a diferentes valores de temperatura e $\mathrm{pH}$ e níveis de glicosilação da proteína. $K$. lactis apresentou os maiores níveis de produção de esterase (294 U/g MS) num sistema epissomal, no qual o promotor e terminador ScPGK foram utilizados para proporcionar a expressão da esterase. Nos cultivos de $K$. marxianus, a parcela de enzima presente no sobrenadante foi maior que nos cultivos em $K$. lactis. A análise 
de $N$-glicosilação mostrou que $K$. marxianus e $K$. lactis editaram a esterase em três diferentes padrões: totalmente desglicosilada, glicosilada em um ponto e glicosilada em dois pontos. A inserção de cadeias de açúcares pelas leveduras pode ter sido responsável por modificações em sua termoestabilidade. As esterases produzidas apresentaram atividade máxima em pH entre 8,0 e 9,0 e a temperaturas de $50{ }^{\circ} \mathrm{C}$ e $45{ }^{\circ} \mathrm{C}$ para $\mathrm{K}$. marxianus e $\mathrm{K}$. lactis, respectivamente. Os resultados obtidos neste trabalho indicam que K. marxianus é capaz de expressar uma enzima termofílica, mas as modificações pós-traducionais podem interferir nas propriedades bioquímicas das proteínas.

\section{Introdução}

A expressão de genes heterólogos em $K$. marxianus foi reportada em alguns poucos artigos. Após o trabalho pioneiro de Bergkamp et al. (1993), os quais expressaram a enzima alfa-galactosidase da planta Cyamopsis tetragonoloba à concentração de $153 \mathrm{mg} / \mathrm{L}$ com 99\% de eficiência de secreção (incluindo ambas frações periplásmica e extracelular), levou um certo tempo antes que Ball et al. (1999) reportassem a expressão de $\beta$-glucosidase a $10 \mathrm{U} / \mathrm{mg}$ de proteína (dado obtido a partir de gráfico). Após, Almeida et al. (2003) expressaram o gene que codifica para a enzima giceraldeído-3-fosfato desidrogenase de uma linhagem floculenta de K. marxianus em outra linhagem da mesma espécie que não flocula, provocando a floculação desta. Pecota et al. (2005) reportaram a produção intracelular de $\beta$-glucuronidase heteróloga em $K$. marxianus. Na mesma época, Cai et al. (2005) publicaram sobre a expressão extracelular de interferon $\alpha-2 a$ a $60 \mathrm{mg} / \mathrm{L}$ numa linhagem de $K$. cicerisporus (sinônima de $K$. marxianus). Em seguida, Pecota et al. (2007) expressaram lactato desidrogenase de Bacillus megaterium em $\mathrm{K}$. marxianus utilizando a primeira construção integrativa reportada para esta espécie. Mais recentemente, Nonklang et al. (2008) publicaram a expressão de $\alpha$-amilase de Aspergillus oryzae em K. marxianus.

O sistema desenvolvido por Hong et al. (2007), para expressão heteróloga de celulares termofilicas em $K$. marxianus, aproveitou a característica termotolerante 
desta levedura (Fatichenti e Berardi, 1987; Rouwenhorst et al., 1988; Hari-Krishna et al., 2001). Foram clonados e expressos, simultaneamente, os genes codificadores das seguintes enzimas termoestáveis: endo- $\beta$-1,4-glucanase, celobioidrolase e $\beta$ glucosidase, gerando uma linhagem capaz de crescer utilizando celobiose ou carboximetilcelulose como únicas fontes de carbono. A capacidade de crescimento a altas temperaturas apresentada por K. marxianus é interessante para aplicações industriais, pois resulta num menor custo de resfriamento das dornas e numa menor possibilidade de desenvolvimento de organismos contaminantes. Seria este o caso do processo de hidrólise da celulose e subsequente sacarificação, no qual uma temperatura de processo de $50{ }^{\circ} \mathrm{C}$ diminui a energia necessária para resfriamento do reator e diminuem as chances de contaminação do mesmo (Hong et al., 2007). Essa capacidade também pode ser aproveitada na expressão de enzimas termoestáveis, como a esterase de $T$. thermophilus (EST), reportada no presente trabalho, já que, provavelmente, tal organismo apresente melhor capacidade para executar uma correta edição da proteína termofílica.

Carboxilesterases (esterases, EC 3.1.1.1) e lipases (EC 3.1.1.3) são enzimas que catalisam a hidrólise de carboxil-ésteres e são encontradas em vários organismos, incluindo animais, plantas, fungos e bactérias. As esterases são enzimas capazes de hidrolisar ésteres de ácidos graxos de cadeia curta. A definição de cadeia curta pode variar entre estruturas de 6 (Bornscheuer, 2002) e 10 (Choi et al., 2004; Fuciños et al., 2005) átomos de carbono. Além disso, Arpigny e Jaeger (1999) adicionaram a essa classificação o fato que esterases são capazes de hidrolisar somente moléculas solúveis em água, enquanto as lipases necessitam de uma concentração mínima de substrato para ativar o sítio ativo. Este é liberado com a abertura de uma tampa, a qual torna possível o acesso da enzima a moléculas na fase orgânica (Bornscheuer, 2002). Com isso, uma esterase termofílica une as características de hidrolisar carboxil-ésteres com a termoestabilidade. Esta última característica é somente possível devido à estrutura única das proteínas termofílicas, as quais possuem uma grande quantidade de pontes salinas e ligações intercadeias, além de uma grande fração de seus resíduos na conformação de $\alpha$ hélice (Kumar et al., 2000; Sadeghi et al., 2006). Uma aplicação potencial para esterases termofílicas está na produção de biodiesel, atuando como catalisador na remoção do glicerol dos triglicérides (Al-Zuhair et al., 2007), processo que 
normalmente é conduzido utilizando-se metanol ou etanol para remoção química do glicerol a temperaturas de até $60^{\circ} \mathrm{C}$.

Com o objetivo de avaliar o potencial de $K$. marxianus como hospedeira na produção heteróloga de uma proteína termofílica, não somente em termos de níveis de expressão, mas também em relação a $\mathrm{N}$-glicosilações (a esterase possui dois potenciais sítios para adição de açúcares $N$-ligados), localização subcelular e propriedades termocinéticas da proteína heteróloga, foi clonado o gene da esterase de Thermus thermophilus HB27 em K. marxianus CBS 6556 e em K. lactis CBS 2359, utilizando dois diferentes sistemas epissomais e um integrativo. Até onde se conhece, este é o primeiro relato de uma enzima termotolerante expressada em $K$. marxianus no qual o padrão de glicosilação, a localização subcelular, a estabilidade e as propriedades cinéticas são estudadas. Como as construções foram estabelecidas tanto para $K$. marxianus quando para $K$. lactis, será possível verificar a influência de utilizar um organismo termotolerante na expressão de uma enzima termofílica, já que esta última levedura não cresce acima dos $40^{\circ} \mathrm{C}$, ao contrário da primeira.

\section{Materiais e métodos}

\subsection{Linhagens e meios de cultivo}

Escherichia coli DH10b (Invitrogen, EUA) foi utilizada para a construção e propagação dos plasmídeos. Kluyveromyces marxianus CBS 6556 foi adquirida do Centraal Bureau voor Schimmelcultures (Ultrecht, Holanda). Kluyveromyces lactis PM5-3C (MATa uraA Rag ${ }^{+}$) foi gentilmente cedida pela Dra. Micheline WesolowskiLouvel (Lyon, França). Saccharomyces cerevisiae BY4742 (MATa his3D1 leuD0 lys2D0 ura3D0) (Brachmann et al., 1998) foi fornecida pelo Euroscarf (Frankfurt, Alemanha). A linhagem $K$. marxianus SLC33 é um mutante ura3 de $K$. marxianus CBS 6556, construída neste trabalho por seleção em ágar 5-FOA (a estabilidade do fenótipo ura- foi comprovada por 120 gerações). 
A linhagem de $E$. coli foi cultivada em meio LB ( $1 \%$ triptona, $0,5 \%$ extrato de levedura, $0,5 \% \mathrm{NaCl}, 0,1 \%$ glicose), em meio líqüido ou sólido ( $2 \%$ bacto-agar) a 37 ${ }^{\circ} \mathrm{C}$. Para seleção de transformantes, ampicilina foi adicionada a concentração final de $40 \mathrm{mg} / \mathrm{L}$. Para a seleção das leveduras que apresentam expressão de URA3, foi utilizado o meio CM (Zitomer et al., 1976) sem uracila (CM-URA). As placas 5-FOA para a seleção de mutantes ura3 foram feitas segundo descrito por Boeke et al., 1984). O primeiro screening das leveduras que expressavam EST foi feito em meio YPHSM-SUC ( $8 \%$ peptona, $1 \%$ extrato de levedura, 3\% glicerol, $1 \%$ sacarose). Para os estudos de expressão da esterase, as linhagens foram cultivadas em meio definido (MD) descrito por Verduyn et al. (1992) e em seguida em meio YPS (1\% extrato de levedura, $2 \%$ peptona, $2 \%$ sacarose).

\subsection{Isolamento e manipulação de ácidos nucléicos}

DNA plasmidial de E. coli foi obtido utilizando o kit Spin Clean Plasmid Miniprep (Mbiotech, Coréia do Sul). O DNA plasmidial das células de levedura foram extraídos utilizando o mesmo kit comercial da extração em bactérias, com a diferença dos seguintes passos: antes da miniprep normal, $10 \mathrm{~mL}$ de um cultivo de $24 \mathrm{~h}$ em meio $\mathrm{CM}$ foi centrifugado. O pelet foi ressuspendido em $250 \mu \mathrm{L}$ de tampão de ressuspensão e $250 \mu \mathrm{L}$ de tampão de lise (fornecidos com o kit) e aproximadamente $250 \mu \mathrm{L}$ de pérolas de vidro (425-600 $\mu \mathrm{m}$, Sigma, EUA). A mistura foi agitada em vórtex vigorosamente por 2 minutos e mantida em gelo por mais 5 minutos. Logo após, o protocolo de miniprep foi seguido. A suspensão final de DNA foi utilizada diretamente para transformação de E. coli propagação do plasmídeo. A transformação das leveduras por acetato de lítio foi realizada conforme descrito por Ito et al. (1983). Já o método de transformação foi adaptado do protocolo descrito por Kooistra et al. (2004), como descrito a seguir. $10 \mathrm{~mL}$ de uma cultura de leveduras no início da fase exponencial foram centrifugados ( $4000 \mathrm{x} \mathrm{g,} 5$ minutos) e lavados com $1 \mathrm{~mL}$ de água ultra pura. Em seguida, as células foram ressuspendidas em $1 \mathrm{~mL}$ de tampão de pré-tratamento (meio YPD contendo $200 \mathrm{mM}$ DTT e $300 \mathrm{mM}$ HEPES) e incubado a $30{ }^{\circ} \mathrm{C}$ por 30 minutos. Então, as células foram centrifugadas (4000 x g, 5 minutos) e ressuspendidas em $1 \mathrm{~mL}$ de tampão de eletroporação (10 
$\mathrm{mM}$ Tris- $\mathrm{HCl} \mathrm{pH}$ 7,5, sacarose $270 \mathrm{mM}$, acetato de lítio $1 \mathrm{mM}$ ). O choque elétrico foi realizado segundo os seguintes parâmetros: $25 \mu \mathrm{F}, 550 \mathrm{~V}, 600 \Omega$.

As reações de PCR foram realizadas em um volume final de $25 \mu \mathrm{L}$ que continham $20 \mathrm{ng}$ do DNA molde, $30 \mathrm{pmol}$ de cada primer (Tabela 5.1), $5 \mathrm{nmol}$ (para o gene da esterase) ou 1,75 (para o cassete INU1) nmol de cada dNTP, KCl 50 mM, $\mathrm{MgCl}_{2}$ 2,5 mM, $1 \mu \mathrm{L}$ de DMSO (somente para EST), $1 \mathrm{U}$ (EST) ou 0,25 U (INU1) de Taq DNA polimerase (Roche Diagnostics, Alemanha). A mistura foi tamponada em tampão Tris- $\mathrm{HCl} 10$ mM, pH 8,3. Após, as reações foram executadas em 30 ciclos: a desnaturação foi realizada a $95{ }^{\circ} \mathrm{C}$ (EST) ou $94{ }^{\circ} \mathrm{C}$ (INU1) por 30 segundos, já o anelamento, a $55^{\circ} \mathrm{C}$ por 30 segundos (EST) ou a $53^{\circ} \mathrm{C}$ para o cassete INU1 por 60 segundos). A extensão ocorreu a $72{ }^{\circ} \mathrm{C}$ por 1 minutos (EST) e 3 minutos (INU1). Todas as outras manipulações foram executadas conforme descrito por Sambrook et al. (2001).

Tabela 5.1. Lista dos primers utilizados nas construções de DNA.

\begin{tabular}{|c|c|c|}
\hline Primer & Seqüência & Detalhes \\
\hline PSEST1KF & 5'- GAATTCAGGGCCTCGAGGCCTTCTGG & \multirow{2}{*}{$\begin{array}{l}\text { Amplificar o gene da esterase de } T \text {. } \\
\text { thermophilus para cloná-lo no } \\
\text { plasmídeo pSPGK1 }\end{array}$} \\
\hline PSEST1KR & 5'- GAATTCTCAAGGCCGCACCCGGGGGG & \\
\hline PINU1Fb & $\begin{array}{l}\text { 5'- GGATCCGAATTCTCAAACCGAA } \\
\text { ATGGG }\end{array}$ & \multirow{2}{*}{$\begin{array}{l}\text { Amplificar o cassete INU1 (promotor + } \\
\text { sinal de secreção + CDS + terminador) } \\
\text { de K. marxianus CBS6556 }\end{array}$} \\
\hline PINU1Rb & $\begin{array}{l}\text { 5'- GGATCCACGCCAGACGTCTTGTGT } \\
\text { CCG }\end{array}$ & \\
\hline PINUESTF & $\begin{array}{l}\text { ' -GTCAGTGCTTCAGTTATCAATTACA } \\
\text { AGAGAATGAAGCGGCTTATCGCG }\end{array}$ & \multirow{2}{*}{$\begin{array}{l}\text { Amplificar o gene da esterase de } T \text {. } \\
\text { thermophilus. Possui cauda de } \\
\text { recombinação (sublinhada) para a } \\
\text { seqüência sinal de secreção } \\
\text { (PINUESTF) e terminador (PINUESTR) } \\
\text { do qene INU1 }\end{array}$} \\
\hline PINUESTR & $\begin{array}{l}\text { 5' - TTTTGTCGTTAGTAAAGTAAGCAGA } \\
\text { TCAGATCAAGGCCGCACCCGGGG }\end{array}$ & \\
\hline
\end{tabular}

3.3. Construção dos plasmídeos e transformação das leveduras

O vetor epissomal pSPEST (Figura 5.1A) foi construído como descrito a seguir. A CDS da esterase de Thermus thermophilus HB27 foi amplificada por PCR a partir do DNA cromossomal da bactéria utilizando os primers PSEST1KF e PSEST1KR (Tabela 5.1). O fragmento de $990 \mathrm{pb}$ amplificado foi clonado no plasmídeo replicativo pSPGK1 (Fleer et al., 1991). Esse plasmídeo possui a origem de replicação S11 de 
$K$. lactis, apresentado habilidade de se replicar tanto em células de $K$. lactis quanto de K. marxianus. O plasmídeo resultante (pSPEST, Figura $5.1 \mathrm{~A}$ ) foi utilizado para transformar células de $K$. marxianus SLC33 e de $K$. lactis PM5-3C. Os transformantes exibiram capacidade de crescer em placas CM-URA e a seleção dos que expressavam maior quantidade de esterase foi realizada por cultivo em meio YPHSM-SUC e por medição da atividade extracelular de esterase por miligrama de biomassa. A linhagem que apresentou maior atividade de cada construção foi utilizada para os estudos posteriores.

As construções que utilizaram o cassete INU1 para a expressão da esterase iniciaram com a amplificação do cassete INU1 a partir do DNA cromossomal de $K$. marxianus CBS 6556 utilizando os primers PINU1Fb e PINU1Rb (Tabela 5.1). Ambos os primers possuíam em suas extremidades 5' um sítio de restrição BamHI. Após a amplificação, o cassete INU1 foi ligado no vetor pMBL1-T (Mbiotech, Coréia do Sul) para propagação. Então o inserto foi retirado por digestão com $B a m H I$ e o cassete clonado no vetor Yeplac 195. A construção resultante foi linearizada com Th1111. Em paralelo, a CDS da esterase de T. thermophilus HB27 foi amplificada a partir do DNA cromossomal da bactéria utilizando os primers PINUESTF e PINUESTR (Tabela 5.1). Esses dois primers eram capazes de adicionar extremidades ao gene amplificado, as quais eram homólogas ao sinal de secreção e terminador INU1. O fragmento resultante foi clonado no vetor pMBL1-T para propagação. Para a inserção da CDS da esterase em INU1, o vetor Yeplac195 contendo INU1 linearizado e o fragmento amplificado de EST foram fundidos por recombinação homóloga em S. cerevisiae BY4727. Uma suspensão de célular com densidade ótica de 0,6 foi transformada com igual proporção de plasmídeo e inserto (500 ng) pelo método de acetato de lítio. A construção foi extraída de células de $S$. cerevisiae e digerida com BamHI, o que fez com que o cassete de expressão de EST fosse liberado. Após propagação do cassete de 2,6 kb em pMBL1-T, esse fragmento foi clonado nos plasmídeos de expressão pSPGK1 e pNADFL11 no sítio $B a m H I$, resultando nas construções epissomal e integrativa mostradas nas Figuras 5.1B e 5.1C, respectivamente.

Os vetores de expressão foram usados para transformar K. marxianus SLC 33 e $K$. lactis PM5-3C pelo método de acetato de lítio, com exceção da construção integrativa em $K$. marxianus. Neste caso, a levedura foi transformada por 
eletroporação, já que o método químico não foi eficiente. As construções estão detalhadas na Tabela 5.2 e na Figura 5.1.

Após a transformação das leveduras, as linhagens selecionadas foram cultivadas em meio YPHSM-SUC por $36 \mathrm{~h}$ e a atividade de esterase foi determinada. Os candidatos de cada construção que apresentaram maior atividade foram selecionados para os estudos posteriores.

Tabela 5.2. Lista das seis construções obtidas neste trabalho e seus detalhes.

\begin{tabular}{|c|c|c|c|c|c|c|}
\hline Construção & $\begin{array}{c}\text { Espécie } \\
\text { hospedeira }\end{array}$ & $\begin{array}{l}\text { Nome do } \\
\text { plasmídeo }\end{array}$ & Tipo & Promotor & $\begin{array}{l}\text { Sinal de } \\
\text { secração }\end{array}$ & Terminador \\
\hline $\mathrm{Km} 1$ & K. marxianus & pSPEST & Episomal & Sc PGK & $K / \mathrm{k} 1$ & Sc PGK \\
\hline $\mathrm{Km} 2$ & K. marxianus & pSPINEST & Episomal & Km INU1 & Km INU1 & Km INU1 \\
\hline $\mathrm{Km} 3$ & K. marxianus & pINESTi & Integrative & Km INU1 & Km INU1 & Km INU1 \\
\hline $\mathrm{KI} 1$ & K. lactis & pSPEST & Episomal & Sc PGK & $K / \mathrm{k} 1$ & Sc PGK \\
\hline $\mathrm{K} / 2$ & K. lactis & pSPINEST & Episomal & Km INU1 & Km INU1 & Km INU1 \\
\hline $\mathrm{KI} 3$ & K. lactis & pINESTi & Integrative & Km INU1 & Km INU1 & $\mathrm{Km} I N U 1$ \\
\hline
\end{tabular}
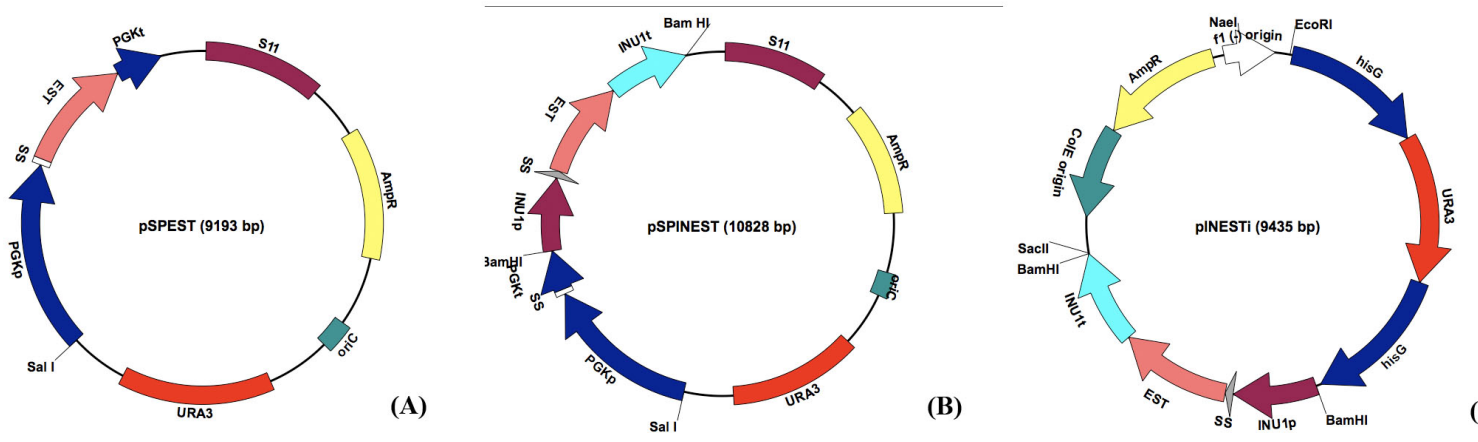

Figura 5.1. Sistemas de expressão desenvolvidos neste trabalho. (A) pSPEST promove expressão epissomal de esterase termofílica sob controle do promotor SCPGK; (B) pSPINEST é um vetor epissomal que permite a expressão de EST sob controle do promotor KmINU1; (C) pINESTi é um plasmídeo integrativo que confere à célula capacidade de expressar esterase sob controle do promotor KmINU1. (A) e (B) derivam do vetor pSPGK1 (Fleer et al., 1991) e (C) do pNADFL11 (Pecota et al., 2007). Legenda: p, promotor; t, terminador; SS, sinal de secreção.

\subsection{Determinação da atividade de esterase}

A atividade de esterase foi determinada usando o laurato de p-nitrofenil como substrato, de acordo com o método descrito por Fuciños et al. (2005). Em um tubo 
de ensaio, foram adicionados $800 \mu \mathrm{L}$ do tampão Tris-HCl (pH 8 a $65^{\circ} \mathrm{C}$ ) contendo $40 \mathrm{mM}$ de $\mathrm{CaCl}_{2}$ e $100 \mu \mathrm{L}$ de uma solução etanólica de laurato de p-nitrofenil a 25 $\mathrm{mM}$. O tubo foi incubado a $65^{\circ} \mathrm{C}$ por 10 minutos para estabilização da temperatura. Finalmente, $100 \mu \mathrm{L}$ da amostra foram adicionados. A reação de hidrólise foi mantida incubada por 10 minutos a $65^{\circ} \mathrm{C}$ e, ao cabo do tempo, $250 \mu \mathrm{L}$ de uma solução $2 \mathrm{M}$ de $\mathrm{Na}_{2} \mathrm{CO}_{3}$ foram adicionados para parar a reação. $\mathrm{A}$ mistura foi mantida em gelo por 15 minutos antes de ser centrifugada ( $2500 \times$ g por 15 minutos). A absorbância do sobrenadante foi determinada a $400 \mathrm{~nm}$ em um espectrofotômetro Thermo Genesys 20 (Waltham, EUA). Nessas condições, o coeficiente de extinção molar do produto é $17,215 / \mathrm{mM} / \mathrm{cm}$. Uma unidade de atividade da esterase é definida como a quantidade de enzima necessária para liberar $1 \mu \mathrm{mol}$ de produto por minuto nas condições supracitadas.

\subsection{Análise da produção de esterase em cultivos submersos}

As condições descritas por Bergkamp et al. (1993), as quais resultaram em uma produção extracelular eficiente da enzima alfa-galactosidase em K. marxianus, foram adotadas com pequenas modificações, para avaliar a expressão e secreção da esterase de $T$. thermophilus em $K$. marxianus CBS 6556 e em $K$. lactis CBS 2359. Os transformantes foram crescidos em frascos chicanados de $500 \mathrm{~mL}$ contendo $100 \mathrm{~mL}$ de meio, agitados a $300 \mathrm{rpm}$ e incubados a $30^{\circ} \mathrm{C}$. Primeiramente, as células foram cultivadas por $24 \mathrm{~h}$ em MD (utilizando $2 \%$ de glicose como fonte de carbono). Depois, as células foram diluídas na proporção de 1:10 em meio YPS e cultivadas por outras $48 \mathrm{~h}$. Todos os cultivos foram realizados em duplicata. $\mathrm{Na}$ seqüência, a enzima heteróloga presente no sobrenadante, a fração retida no espaço periplásmico e a fração intracelular foram separadas de acordo com o método descrito por Rouwenhorst et al. (1988). A liberação da fração periplásmica foi induzida pela suspensão das células em $10 \mathrm{~mL}$ do tampão de liberação (tampão fosfato $50 \mathrm{mM}, \mathrm{pH}$ 7, 2-mercaptoetanol $10 \mathrm{mM}$, ditiotreitol $10 \mathrm{mM} \mathrm{e} \mathrm{MgCl}_{2}$ ). A fração intracelular foi liberada incubando as células, das quais já tinha sido extraída a fração periplásmica, em tampão fosfato $100 \mathrm{mM} \mathrm{pH} \mathrm{7,} \mathrm{contendo} 2 \mathrm{mM}$ de $\mathrm{MgCl}_{2}$, 
DTT $2 \%$, e $5 \%$ de coquetel de inibidores de protease (Produto no. P8215, Sigma, USA). Pérolas de vidro $(425-600 \mu \mathrm{m})$ foram adicionadas e o rompimento total das células foi realizado agitando a mistura em vórtex por 5 períodos de 1 minuto, sendo que entre cada dois períodos, a solução era incubada em gelo por 1 minuto. Os debris celulares foram separados por centrifugação e o sobrenadante foi utilizado como contendo a fração intracelular.

A atividade de esterase foi determinada espectrofotometricamente nessas três frações. O conteúdo de proteína em todas as frações foi medido pelo método de Bradford (produto B6916, Sigma, EUA), utilizando albumina bovina como padrão, de acordo com as instruções do fabricante. A biomassa seca de cada amostra de $5 \mathrm{~mL}$ foi determinada para cada frasco de cultivo, utilizando-se filtração da suspensão celular em membranas de $0,45 \mu \mathrm{m}$ e posterior secagem em forno de microondas (180 W, $15 \mathrm{~min}$ ) (Olsson e Nielsen, 1997).

\subsection{Análises de glicosilação da esterase}

A esterase expressada pelas seis diferentes construções de $K$. marxianus e $K$. lactis (Tabela 5.2) foi analisada em relação ao grau de glicosilação nas frações do sobrenadante e periplásmica. Para tal, o sobrenadante e a fração periplásmica foram concentrados em ultrafiltros de corte $10 \mathrm{kDa}$ (Millipore, EUA). Para esse propósito, $15 \mu \mathrm{g}$ da proteína foi desnaturada por incubação por 30 minutos a $100{ }^{\circ} \mathrm{C}$ em $10 \mu \mathrm{L}$ de reação que continha SDS a 0,5\% e 2-mercaptoetanol a $40 \mathrm{mM}$. Após o resfriamento, foram adicionados Tergitol NP-40, tampão fosfato $\mathrm{pH}$ 7,5 e PNGase F (New England Biolabs, EUA) às respectivas concentrações de $1 \%, 50 \mathrm{mM}$ e $5 \mathrm{U} / \mu \mathrm{L}$, em um volume final de reação de $20 \mu \mathrm{L}$. A mistura foi incubada por 2 horas a $37^{\circ} \mathrm{C}$. Os padrões de migração das formas glicosiladas e desglicosiladas foram comparadas em géis de SDS-PAGE a $10 \%$. A atividade de esterase foi determinada diretamente no gel utilizando o substrato $\alpha$-naftil-acetato, conforme descrito anteriormente (Schmidt-Dannert et al., 1996), com a diferença que a reação foi incubada a $65{ }^{\circ} \mathrm{C}$. Após a incubação, esterases ativas apareciam em bandas avermelhadas. Depois dessa reação específica, os géis foram submetidos a 
coloração com coomassie blue R-250, conforme descrito por Laemmli et al. (1970), para revelar as outras proteínas presentes em cada raia da eletroforese.

\subsection{Caracterização bioquímica da esterase}

A enzima sintetizada pelos transformantes de cada espécie, tanto $K$. lactis quanto $K$. marxianus, que exibiram maior atividade enzimática por massa de células nas frações sobrenadante e periplásmica, foram sujeitas à caracterização bioquímica, na qual o $\mathrm{pH}$ e temperatura de atividade ótima e a estabilidade a diferentes $\mathrm{pHs}$ e temperaturas foram estudados. A atividade de EST foi determinada nos seguintes valores de $\mathrm{pH}: 3,4,5$ (tampão acetato $50 \mathrm{mM}$ contendo $\mathrm{CaCl}_{2} 40$ mM), 6, 7, 8 (tampão HEPES 50 mM contendo $\mathrm{CaCl}_{2} 40 \mathrm{mM}$ ), 8,6, 9, 9,5, 10,2 (tampão Tris $50 \mathrm{mM}$ contendo $\mathrm{CaCl}_{2} 40 \mathrm{mM}$ ). A estabilidade térmica foi determinada durante quatro horas de incubação a $80{ }^{\circ} \mathrm{C}, 85^{\circ} \mathrm{C}$ e $90{ }^{\circ} \mathrm{C}$. As amostras foram retiradas nos tempos $0,1,2$ e 4 horas e a atividade da enzima foi determinada imediatamente. A estabilidade ao $\mathrm{pH}$ foi determinada medindo-se a atividade residual da enzima após 2 horas de incubação da enzima a $65^{\circ} \mathrm{C}$ nos tampões (de pH 3 a 10,2) mencionados acima. A temperatura ótima para atividade enzimática foi determinada incubando a enzima nas seguintes temperaturas: $40^{\circ} \mathrm{C}, 45^{\circ} \mathrm{C}, 50^{\circ} \mathrm{C}$, $55^{\circ} \mathrm{C}, 60^{\circ} \mathrm{C}, 65^{\circ} \mathrm{C}$ e $75^{\circ} \mathrm{C}$.

\section{Resultados e Discussão}

4.1. Níveis de expressão de esterase

De acordo com a Tabela 5.3, todas as construções foram capazes de promover a expressão e a secreção parcial da esterase heteróloga. Quando K. marxianus foi utilizada como hospedeira, os transformantes $\mathrm{Km} 1$ e $\mathrm{Km} 3$ cresceram até uma concentração final de $11,5 \mathrm{~g} / \mathrm{L}$, o que indica uma conversão normal de biomassa em 
substrato, já que a concentração inicial da fonte de carbono dos cultivos era de aproximadamente $20 \mathrm{~g} / \mathrm{L}$. As células contendo essas duas construções foram capazes de secretar até o sobrenadante aproximadamente a metade da esterase produzida, mas $30 \%$ ficou retida dentro da célula. Em contrapartida, a construção Km2 exibiu uma conversão em biomassa dez vezes inferior ao final do cultivo em batelada. Isso indica que esta construção epissomal exerceu influência sobre a fisiologia da célula, talvez por carregar um plasmídeo grande (maior que $10 \mathrm{~kb}$ ) ou por outro estresse como a resposta à proteína mal-editada (UPR, do inglês unfolded protein response) (Mattanovich et al., 2004). Apesar de o transformante $\mathrm{Km} 2$ secretar uma quantidade maior de esterase relativa à proteína total produzida que $\mathrm{Km} 1$ e Km3, isso ocorreu porque a quantidade de enzima intracelular foi significativamente inferior ao determinado nas duas outras construções em $K$. marxianus. Isso pode indicar que, no caso deste transformante, a proteína sofreu degradação intracelular por UPR.

K. lactis expressou níveis mais altos de esterase que $K$. marxianus em ambos os tipos de construção, ou seja, tanto com o promotor PGK quanto com o promotor INU1. Esse resultado se opõe aos dados publicados por Bergkamp et al. (1993), que observaram uma expressão muito mais alta da enzima $\alpha$-galactosidase em $K$. marxianus quando o promotor homólogo INU1 foi utilizado. Esta levedura produziu $153 \mathrm{mg} / \mathrm{L}$ da enzima, enquanto $K$. lactis expressando a mesma enzima sob controle do promotor $P G K$ produziu $90 \mathrm{~g} / \mathrm{L}$. A mesma lógica foi observada no Capítulo 4 desta Tese, em que K. marxianus expressou GOX em maiores níveis que K. lactis, quando foi utilizado o promotor INU1 e o inverso ocorreu na utilização do promotor PGK.

Tabela 5.3. Produção heteróloga de esterase no sobrenadante, periplasma e intracelular nas diferentes construções de $K$. marxianus e K. lactis.

\begin{tabular}{|c|c|c|c|c|c|c|c|c|}
\hline \multirow{3}{*}{$\begin{array}{l}\text { Cons- } \\
\text { tru- } \\
\text { ção }^{\text {(a) }}\end{array}$} & \multirow{3}{*}{$\begin{array}{c}\begin{array}{c}\text { Biomassa } \\
\text { Final }^{(\mathbf{b})}\end{array} \\
(\mathrm{gMS} / \mathrm{L})\end{array}$} & \multicolumn{7}{|c|}{ Atividade de esterase ${ }^{(c)}$} \\
\hline & & \multicolumn{2}{|c|}{ Sobrenadante } & \multicolumn{2}{|c|}{ Periplasma } & \multicolumn{2}{|c|}{ Intracelular } & Total \\
\hline & & U/mgProt & U/gMS & $\mathrm{U} / \mathrm{mgProt}$ & U/gMS & U/mgProt & U/gMS & U/gMS \\
\hline $\mathrm{Km} 1$ & $11,6 \pm 0,3$ & $5,1 \pm 1,1$ & $22,5 \pm 3,5$ & $7,6 \pm 0,9$ & $8,4 \pm 0,4$ & $0,2 \pm 0,0$ & $18,5 \pm 0,7$ & $49,4 \pm 4,6$ \\
\hline $\mathrm{Km} 2$ & $1,6 \pm 0,0$ & $4,8 \pm 1,1$ & $29,5 \pm 0,7$ & $0,2 \pm 0,0$ & $7,6 \pm 1,1$ & $0,2 \pm 0,0$ & $3,4 \pm 0,2$ & $40,5 \pm 0,1$ \\
\hline $\mathrm{Km} 3$ & $11,4 \pm 0,1$ & $6,1 \pm 0,3$ & $28,5 \pm 0,7$ & $17,2 \pm 0,4$ & $8,9 \pm 0,4$ & $0,6 \pm 0,1$ & $19,5 \pm 0,7$ & $56,9 \pm 1,0$ \\
\hline $\mathrm{K} / 1$ & $9,9 \pm 0,1$ & $11,8 \pm 3,5$ & $35,0 \pm 1,4$ & $98,5 \pm 6,4$ & $62,5 \pm 9,2$ & $2,4 \pm 0,1$ & $192 \pm 8$ & $294 \pm 0$ \\
\hline $\mathrm{KI} 2$ & $9,2 \pm 0,1$ & $3,9 \pm 0,3$ & $11,0 \pm 0,0$ & $3,7 \pm 0,0$ & $3,0 \pm 0,0$ & $0,7 \pm 0,0$ & $38,0 \pm 0,0$ & $52,0 \pm 0,0$ \\
\hline $\mathrm{KI} 3$ & $9,6 \pm 0,1$ & $9,0 \pm 0,8$ & $30,0 \pm 1,4$ & $101 \pm 7$ & $62,5 \pm 0,7$ & $1,6 \pm 0,1$ & $144 \pm 28$ & $237 \pm 25$ \\
\hline
\end{tabular}

(a) ver seção de Materiais e Métodos, Tabela 5.1 e Figura 5.1. para descrição das construções genéticas;

(b) ver seção de Materiais e Métodos para descrição das condições de cultivo;

(c) fracionamento celular realizado de acordo com Rouwenhorst et al. (1988). 
Isso é uma evidência que a expressão heteróloga é dependente da proteína expressada. As proteínas termofílicas não são diferentes porque possuem propriedades estruturais únicas, mas são proteínas atípicas devido à sua intrínseca estabilidade. As evidências indicam que a maior estabilidade das enzimas termofílicas não podem ser atribuídas a um único fator, mas é resultado de uma série de efeitos estabilizadores como alta hidrofobicidade (Haney et al., 1997), pontes de hidrogênio e ligações iônicas (Vogt et al., 1997), pontes dissulfeto e ligações metálicas (Fontana, 1988), e pontes salinas (Haney et al., 1997; Kumar et al., 2000; Sadeghi et al., 2006). Essas características aumentam a probabilidade de a proteína não ser corretamente editada e pode resultar no decaimento do rendimento de expressão. De acordo com Porro et al. (2005), proteínas que contêm um alto número de pontes dissulfeto são geralmente expressadas em menores níveis em leveduras. Se o enrolamento correto parece ser um gargalo na expressão de enzimas termofílicas, um aumento na transcrição pelo uso de um promotor mais forte ou o aumento do número de cópias do gene não irão incrementar o rendimento final de proteína, mas em contrapartida, poderá acarretar na redução da produtividade e gerar um estresse severo às células do hospedeiro (Mattanovich et al., 2004). No caso deste $K$. marxianus, um menor rendimento em relação a $K$. lactis, mesmo quando se utilizou o promotor INU1, pode ter sido causado por estresse causado pelo incorreto enrolamento da proteína. Essa pode ser uma explicação para o baixo conteúdo intracelular de esterase heteróloga observada em $K$. marxianus quando comparada com $K$. lactis (Tabela 5.4). Levando-se conta que as mesmas linhagens de leveduras expressaram GOX utilizando construções idênticas e que $K$. lactis mostrou possui melhor capacidade de secreção das proteínas, o que se vê na Tabela 5.4 pode parecer contraditório. Porém, os baixos níveis de esterase intracelular de K. marxianus, provavelmente causado por degradação da enzima por UPR, levam ao incremento da proporção extracelular, levando-se à impressão que K. marxianus, neste caso, secretaria maior quantidade de proteína que $K$. lactis. 
Tabela 5.4. Distribuição subcelular de esterase heteróloga nas diferentes construções de $K$. marxianus e $K$. lactis.

\begin{tabular}{lccc}
\hline \multirow{2}{*}{ Construção } & (a) & Atividade de esterase por gMS em cada fração relativa à atividade total & (b,c) \\
\cline { 2 - 4 } & Sobrenadante & Periplasma & Intracelular \\
\hline $\mathrm{Km} 1$ & $45 \% \pm 3 \%$ & $17 \% \pm 1 \%$ & $38 \% \pm 2 \%$ \\
$\mathrm{Km} 2$ & $73 \% \pm 2 \%$ & $19 \% \pm 3 \%$ & $8 \% \pm 1 \%$ \\
$\mathrm{Km} 3$ & $50 \% \pm 0 \%$ & $16 \% \pm 1 \%$ & $34 \% \pm 1 \%$ \\
$\mathrm{~K} 11$ & $12 \% \pm 0 \%$ & $23 \% \pm 3 \%$ & $65 \% \pm 3 \%$ \\
$\mathrm{~K} 2$ & $21 \% \pm 0 \%$ & $6 \% \pm 0 \%$ & $73 \% \pm 0 \%$ \\
$\mathrm{Kl} 3$ & $13 \% \pm 2 \%$ & $27 \% \pm 3 \%$ & $61 \% \pm 5 \%$ \\
\hline
\end{tabular}

(a) ver seção de Materiais e Métodos, Tabela 5.1 e Figura 5.1. para descrição das construções genéticas;

(b) ver seção de Materiais e Métodos para descrição das condições de cultivo;

(c) fracionamento celular realizado de acordo com Rouwenhorst et al. (1988).

Levando-se em consideração que uma solução impura contendo esterase pode atingir uma atividade específica de $100 \mathrm{U} / \mathrm{mg}$ Prot, neste trabalho foi alcançada a produção média de apenas $0,5 \mathrm{mgProt} / \mathrm{mgMS}$. Quando se comparam esses números ao que foi observado na expressão de GOX (Capítulo 4), verifica-se que no outro caso foram alcançados valores 20 vezes maior. Sabe-se que a expressão de enzimas termofílicas em leveduras pode ser influenciada pela existência de códon raros no mRNA que codifica para o peptídeo. Códons que são comuns em espécies como $T$. thermophilus podem ser raros em $K$. marxianus e, com isso, a expressão pode ser limitada pela quantidade de aminoacil-tRNA disponíveis na célula da levedura (Romanos et al., 1992; Daly et al., 2005). Por exemplo, os genes de Thermus thermophilus codificam mRNAs com códons raros para leveduras, como o $\mathrm{CCC}_{\text {pro, }}$ o qual ocorre em $4,2 \%$ dos códons que codificam para a esterase de Thermus thermophilus HB27, similar às outras proteínas de Thermus como a manosil-3-fosfoglicerato sintase e a manosil-3-fosfoglicerato fosfatase, nas quais 0 códon $\mathrm{CCC}_{\text {Pro }}$ está presente em $3,8 \%$ e $6,2 \%$ dos códons totais, respectivamente (Empadinhas et al., 2003). No entanto, proteínas homólogas de $K$. marxianus e $K$. lactis possuem, em média, apenas $0,22 \%$ e $0,45 \%$ do códon mencionado em seu mRNA total, respectivamente (Codon Usage Database, 2009). Isso pode resultar em um decréscimo no rendimento da produção de proteína heteróloga, fenômeno também observado em outros hospedeiros, como E. coli expressando proteínas de Thermoplasma acidophilum (Kim e Lee, 2006) e Pichia pastoris expressando o fator de crescimento da epiderme de camundongo (Clare et al., 1991). Isso indica que um aumento no rendimento de produção da enzima heteróloga poderia ser alcançado pela inserção de mutações, trocando os códons raros por seqüências mais comuns às leveduras. 


\subsection{Caracterização bioquímica da esterase heteróloga}

A caracterização bioquímica realizada neste trabalho, em termos da atividade sob diferentes valores de $\mathrm{pH}$ e temperaturas (Figura 5.2), em termos da estabilidade a diferentes temperaturas (Figura 5.3) e valores de $\mathrm{pH}$ e em termos da estimativa do peso molecular em SDS-PAGE, confirmou que ambas linhagens de leveduras foram capazes de expressar e secretar enzimas bioquimicamente semelhantes.

$\mathrm{O}$ pH ótimo da enzima está entre 8 e 9 para todos os casos investigados (Figura 5.2B). O perfil de atividade de esterase versus $\mathrm{pH}$ para ambas as linhagens é similar ao observado em esterases homólogas de Thermus thermophilus HB27 (Fuciños et al., 2005). No entanto, os autores avaliaram uma mistura de duas enzimas (34 kDa e $62 \mathrm{kDa}$ ) que apresentavam atividade de esterase, e concluíram que uma das duas enzimas possui atividade máxima a pH entre 5 e 7 e uma outra apresentava melhor atividade em $\mathrm{pH}$ 9. Como neste trabalho apenas a menor enzima foi expressada, é mais provável que a esterase de $34 \mathrm{kDa}$ seja a responsável por apresentar atividade máxima em valores de $\mathrm{pH}$ alcalinos. Quando a esterase heteróloga produzida por ambas as espécies de levedura foi incubada a 50 ${ }^{\circ} \mathrm{C}$ por 2 horas em diferentes valores de $\mathrm{pH}$, a atividade permaneceu estável durante o período de incubação do $\mathrm{pH} 4$ ao $\mathrm{pH} 9$.
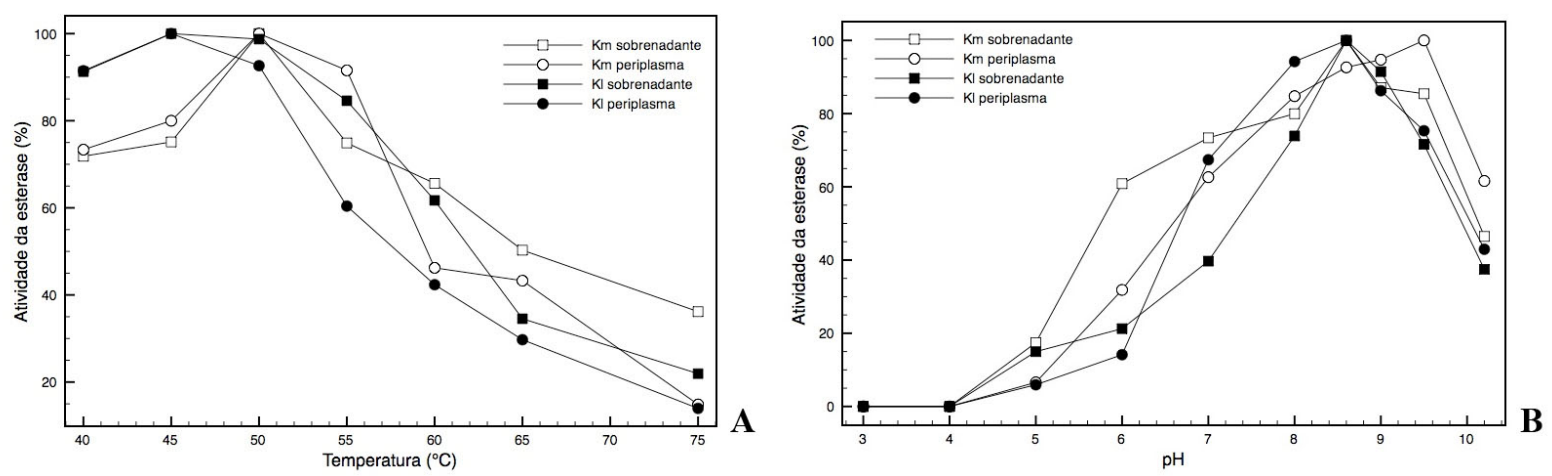

Figura 5.2. Atividade da esterase a diferentes temperaturas e pHs. (A) Gráfico que relaciona a atividade da esterase nas frações subcelulares a temperatura de hidrólise e (B) A atividade de esterase foi determinada em $\mathrm{pH}$ de 3 a 10,6. Cada ponto é a média de uma duplicata. $\mathrm{Km}$ sobrenadante e $\mathrm{Km}$ periplasma: esterase produzida pela construção $\mathrm{Km} 3$. KI sobrenadante e KI periplasma: esterase produzida pela construção KI1.

A análise do efeito da temperatura na atividade ótima das esterases heterólogas foi realizada incubando as enzimas em temperaturas que variavam de 
$40{ }^{\circ} \mathrm{C}$ a $75{ }^{\circ} \mathrm{C}$ (Figura 5.2A). A temperatura ótima de catálise foi de $50{ }^{\circ} \mathrm{C}$ para $\mathrm{K}$. marxianus e de $45^{\circ} \mathrm{C}$ para $K$. lactis para ambas frações: sobrenadante e periplasma. As temperaturas ótimas de atividade foram menores que a determinada por Fuciños et al. (2005), que para a mistura de duas esterases (34 e $62 \mathrm{kDa}$ ), determinaram que a maior velocidade de hidrólise ocorreu a $65{ }^{\circ} \mathrm{C}$. Outra consideração importante é que como as enzimas heterólogas permaneceram estáveis a temperaturas de $80^{\circ} \mathrm{C}$, o decaimento na atividade da enzima que foi incubada a temperaturas acima de 50 ${ }^{\circ} \mathrm{C}$ ocorreu não por desnaturação, mas sim por mudanças reversíveis e parciais na conformação da proteína.

O efeito da temperatura na atividade e estabilidade da enzima heteróloga é uma das mais importantes avaliações quando se expressa uma proteína termofílica. De acordo com a Figura 5.3, a esterase heteróloga de $K$. marxianus permaneceu estável por pelo menos 4 horas a $80^{\circ} \mathrm{C}$. Em contrapartida, a esterase de $K$. lactis que foi secretada ao sobrenadante perdeu praticamente toda sua atividade durante o mesmo período nas mesmas condições. Já a enzima que se manteve no periplasma se apresentou mais estável, perdendo apenas $20 \%$ da atividade no mesmo período. Quando as enzimas foram incubadas a $85{ }^{\circ} \mathrm{C}$ e a $90{ }^{\circ} \mathrm{C}$, elas mostraram perfis de inativação semelhantes e, na última temperatura citada, a atividade de esterase caiu a zero em duas horas de incubação. A esterase heteróloga foi menos estável que aquela produzida pelo próprio $T$. thermophilus, que mantém sua atividade residual em quase $100 \%$ após 2 horas de incubação a $85^{\circ} \mathrm{C}$ (Fuciños et al., 2005). 

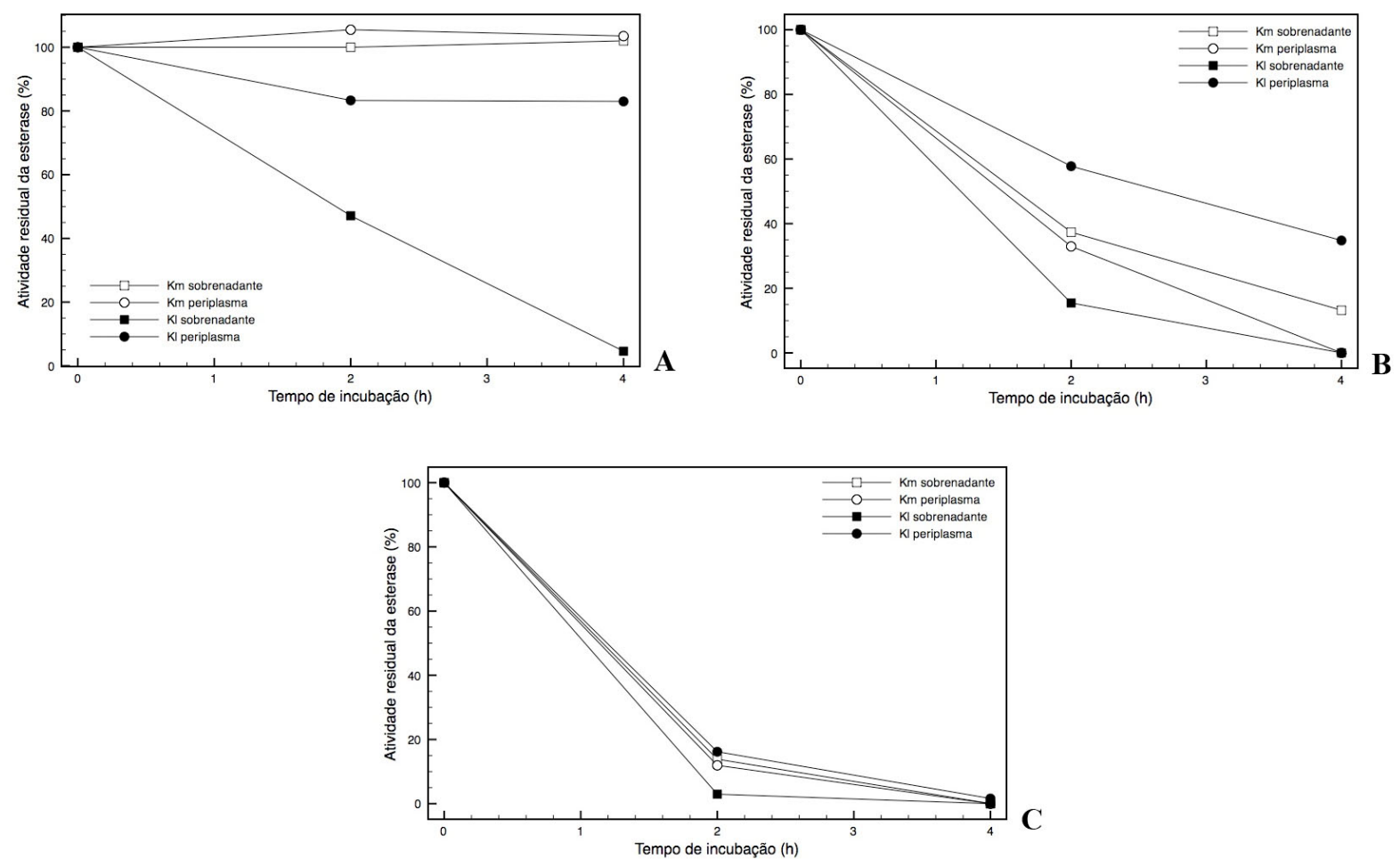

Figura 5.3. Estabilidade da esterase a diferentes temperaturas. A atividade residual da enzima foi medida após mantê-la incubada a (A) $80^{\circ} \mathrm{C}$; (B) $85^{\circ} \mathrm{C}$; (C) $90^{\circ} \mathrm{C}$. Cada ponto é a média de uma duplicata. $\mathrm{Km}$ sobrenadante e $\mathrm{Km}$ periplasma: esterase produzida pela construção $\mathrm{Km} 3$. KI sobrenadante e KI periplasma: esterase produzida pela construção KI1.

Mudanças conformacionais foram provavelmente responsáveis pela perda de estabilidade das proteínas heterólogas frente à temperatura, quando comparadas com as homólogas. Como a esterase de $34 \mathrm{kDa}$ de Thermus thermophilus possui dois sítios para adição de $N$-glicosilações, a inserção de glicídios na estrutura da proteína alterou sua conformação original, sob a qual a enzima possuía maior termoestabilidade. Essas alterações conformacionais levaram ao enfraquecimento das interações eletrônicas responsáveis pela destacada estabilidade das proteínas termófilas. Essa constatação motivou a investigação sobre o padrão de glicosilação das esterases expressadas em $K$. marxianus e $K$. lactis.

Nas Figuras 5.4A e 5.4B é possível verificar que a esterase heteróloga é expressa na forma de três peptídeos ativos tanto em $K$. marxianus quanto em $K$. lactis. Como todos os sistemas de expressão foram desenvolvidos para expressar apenas uma esterase de $34 \mathrm{kDa}$ com dois pontos potenciais para glicosilação, sugere-se que as duas outras bandas mais pesadas são relativas a esterases glicosiladas em dois diferentes níveis, resultando em glicoproteínas de 
aproximadamente 38 kDa e 42 kDa. O mesmo fenômeno já foi observado em outros organismos, como no caso de quitobiosidases homólogas produzidas por Trichoderma harzianum (Harman et al., 1993), em serina proteases extracelulares extraídas do endotélio de veias umbilicais humanas (Rao et al., 1996), e numa lacase produzida por Pleorotus ostreatus (Giardina et al., 1999). Diferentes níveis de glicosilação foram também observados em carboxipeptidase de $S$. cerevisiae (Moehle et al., 1987).
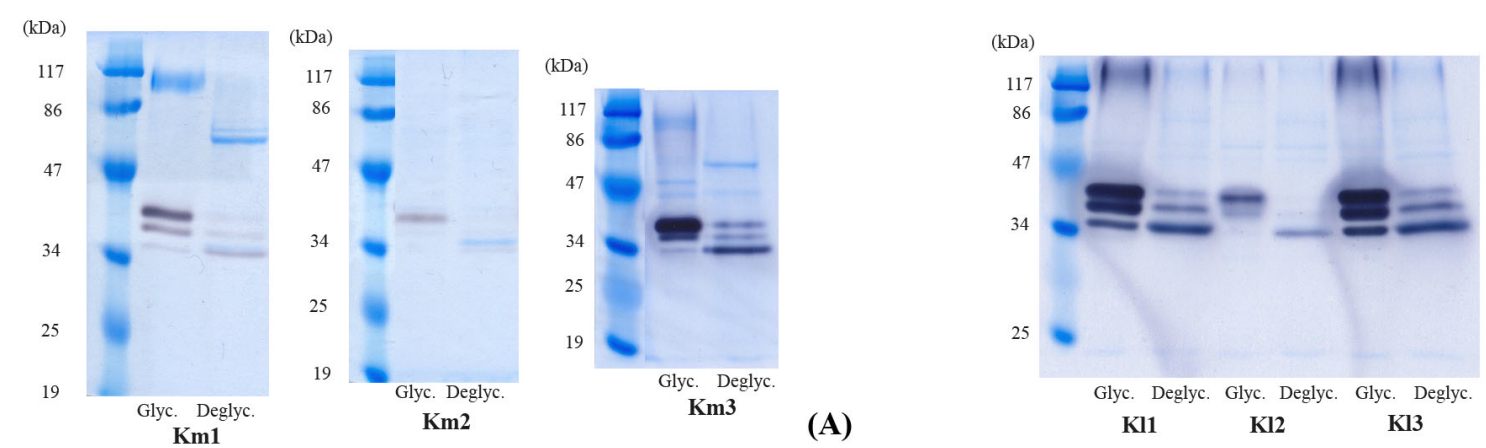

Figura 5.4. SDS-PAGE com duas colorações para a análise do padrão de glicosilação da esterase expressada. Em marrom: bandas com atividade de esterase. Em azul, demais proteínas. (A) Esterase do periplasma de K. marxianus; (B) Esterase do periplasma de K. lactis. Glyc: enzima glicosilada. Deglyc: enzima desglicosilada com PNGase F, como descrito no item sobre métodos. Os códigos das construções estão listados na Tabela 5.2.

Quando as cadeias de carboidrato foram retiradas das esterases heterólogas utilizando-se a enzima PNGaseF, foi possível verificar que em todas as construções, tanto em $K$. marxianus quanto $K$. lactis, a concentração de enzima desglicosilada aumentou em relação às outras duas formas, porém a enzima PNGaseF não foi capaz de clivar todas as ligações Asn-GlcNAc, provavelmente por dificuldade de acesso da enzima de desglicosilação. Vários protocolos, os quais variavam o tempo de desnaturação da enzima e a concentração dos agentes desnaturantes foram testados. Quando a esterase foi incubada por mais de 30 minutos a $100{ }^{\circ} \mathrm{C}$, nenhuma diferença na remoção dos carboidratos foi observada. Além disso, várias concentrações de PNGaseF e tempos de incubação para a hidrólise de glicanos foram testados e não foi observada diferença significativa da remoção dos carboidratos. Dados comunicados verbalmente pela Dra. María Isabel GonzálezSiso, co-autora deste trabalho, trazem a informação de que a retirada total dos açúcares das mesmas três formas de esterase foi realizada com sucesso em seu 
laboratório, utilizando a enzima EndoH, a qual libera as glicosilações, com exceção do resíduo de GIcNAc ligado à asparagina. O resultado foi uma única banda desglicosilada. Portanto, a enzima PNGaseF pode sido impedida de acessar o seu substrato, a ligação GlcNAc-Asn, ao contrário da Endo $\mathrm{H}$, que cliva uma ligação mais periférica, o que pode ter sido o fator que resultou numa maior efetividade da última.

De acordo com a Figura 5.4B, é possível observar que $K$. lactis é capaz de produzir um peptídeo ativo de aproximadamente $130 \mathrm{kDa}$. Esse agregado ativo apresenta peso molecular aproximado de um trímero hipotético da forma mais glicosilada, ou mesmo um tetrâmero formado por peptídeos de $34 \mathrm{kDa}$. Fuciños et al. (2005) mostraram que, a temperatura ambiente, a esterase de $34 \mathrm{kDa}$ de $T$. thermophilus HB27 também existe como um trímero. Como as estruturas das proteínas termofílicas diferem das mesofílicas devido à formação de pontes salinas e de hidrogênio (Sadeghi et al., 2006); Karshikoff et al., 1998), a alta interação eletrostática pode resultar em formação de agregados, como o trímero observado neste caso.

\section{Conclusões}

Foi expressada uma esterase de $34 \mathrm{kDa}$ de Thermus thermophilus em Kluyveromyces marxianus e em Kluyveromyces lactis usando três diferentes sistemas de expressão: dois epissomais e um integrativo. O promotor INU1 foi utilizado em um sistema epissomal ( $\mathrm{Km} 2$ e KI2) e um integrativo ( $\mathrm{Km} 3$ e KI3), enquanto um outro sistema epissomal (inserido em Km1 e Kl1) tinha o promotor PGK de $S$. cerevisiae promovendo a expressão heteróloga da esterase. Os resultados indicaram que os níveis de expressão são dependentes da proteína expressada, já que a expectativa de maior expressão das construções derivadas de INU1 não foram observadas em K. marxianus. Além disso, a termoestabilidade da enzima foi afetada. Enquanto as enzimas heterólogas perderam quase metade de sua atividade quando incubadas a $85{ }^{\circ} \mathrm{C}$ por duas horas, a enzima de Thermus thermophilus não teve sua atividade afetada pelo mesmo período e à mesma 
temperatura. $\mathrm{O} \mathrm{pH}$ ótimo das enzimas produzidas por ambas espécies de Kluyveromyces esteve entre 8 e 9 , valores semelhantes aos determinado em uma das esterases de $T$. thermophilus. A temperatura ótima para atividade de esterase expressada em $K$. marxianus foi de $50{ }^{\circ} \mathrm{C}$, cinco graus mais alta que a temperatura ótima da enzima produzida por $K$. lactis, enquanto a temperatura em que a enzima homóloga apresenta maior atividade é de $65{ }^{\circ} \mathrm{C}$. Sugere-se que essa diferença foi devida à inserção de carboidratos às proteínas pelas leveduras hospedeiras através do mecanismo de glicosilação. Um rearranjo eletrônico nas cargas da proteína pode ter causado modificações nas estruturas essenciais de manutenção da termoestabilidade da molécula. No entanto, não foi possível observar diferenças na quantidade de carboidratos adicionada por cada organismo sobre a enzima. Ambos expressaram esterases em três níveis de glicosilação distintos: desglicosilada, glicosilada em um ponto e glicosilada em dois pontos. Contudo, $K$. marxianus se mostrou capaz de expressar essa enzima termoestável, sendo que esta apresentou uma ligeira diferença em relação à termoestabilidade e à temperatura de máxima atividade que a enzima produzida por $K$. lactis. Essa diferença pode ter sido influenciada pelo caráter termotolerante de $K$. marxianus. 
Conclusões 


\section{Conclusões gerais da Tese}

Este trabalho alcançou os três objetivos principais listados na introdução, que foram:

- Realizar um estudo comparativo entre diferentes linhagens de Kluyveromyces marxianus para verificar qual seria a linhagem mais adequada para ser usada como hospedeira na síntese de proteínas heterólogas;

- Construir sistemas de expressão contendo os genes da glicose oxidase de Aspergillus niger e de uma esterase de Thermus thermophilus. Usar esses sistemas de expressão para transformar células de K. marxianus, cuja linhagem fora selecionada na primeira fase do estudo, e também de $K$. lactis CBS 2359, que serviria para comparar aquela espécie com esta, que é geneticamente próxima e amplamente estudada pela comunidade científica como hospedeira de genes heterólogos;

- Realizar cultivos para verificar os níveis de expressão de cada enzima e caracterizá-las bioquimicamente.

$\mathrm{Na}$ primeira etapa desta Tese, descrita no capítulo 2, foram estudadas 3 linhagens de Kluyveromyces marxianus, sendo que a K. marxianus CBS 6556 se mostrou mais apropriada como hospedeira para a síntese de proteínas heterólogas. Os fatores que levaram a esse resultado foram: a forte característica Crabtreenegativa da linhagem (baixa formação de metabólitos extracelulares em aerobiose e alto fator de conversão de substrato a células) e alta capacidade de produção extracelular da enzima homóloga e glicosilada inulinase.

A segunda etapa, descrita no capítulo 3 , iniciou com a mutação da linhagem $K$. marxianus CBS 6556 para o fenótipo ura-, o que foi realizado por seleção de mutantes estáveis em placas contendo 5-FOA. A partir daí, iniciou-se a construção dos vetores de expressão. Como resultado, foram construídos três sistemas de expressão para cada proteína heteróloga a ser expressa: a glicose oxidase (GOX) de Aspergillus niger e uma esterase de Thermus thermophilus, totalizando 12 sistemas de expressão (já que cada um deles foi inserido tanto na espécie $K$. 
marxianus, como em $K$. lactis). Os sistemas foram: um epissomal, em que os genes estavam sob controle do promotor PGK de S. cerevisiae e com sinal de secreção da proteína killer k1 de K. lactis; outro epissomal, em que os genes estavam sob controle do promotor do gene INU1 de K. marxianus e sinal de secreção da própria inulinase de $K$. marxianus; e um integrativo, com os mesmos elementos genéticos deste último sistema epissomal. Com esse trabalho, foi possível observar fatos antes não descritos, como por exemplo que $K$. lactis é capaz de utilizar o promotor INU1 de K. marxianus para promover síntese de proteínas heterólogas. E também verificou-se que é possível usar um plasmídeo integrativo desenhado para integrar no gene URA3 de K. marxianus, também para integrar no genoma de K. lactis.

$\mathrm{Na}$ terceira etapa, conforme descrito nos capítulos 4 e 5, foi estudada a expressão dos dois genes heterólogos. Verificou-se que a expressão que cada sistema é capaz de conferir depende do gene a ser expresso, pois resultados distintos foram observados quanto à produção das enzimas por cada sistema construído, já que a linhagem Km2 (de K. marxianus) foi a melhor produtora de GOX (1722 U/g MS) e a KI1 (de K. lactis) foi a melhor produtora de esterase (294 U/g MS). Em relação à GOX, foi possível concluir que a enzima heteróloga possuía grande semelhança bioquímica com a enzima homóloga de $A$. niger, apesar de que K. lactis e K. marxianus adicionam mais glicosilações que $A$. niger e a primeira levedura acrescentou um maior número de moléculas de açúcares à cadeia peptídica que a segunda. Em relação à esterase, foi verificado que a enzima produzida em $K$. marxianus apresentou uma estabilidade à temperatura ligeiramente maior que a enzima produzida em $K$. lactis. A temperatura ótima de atividade da esterase foi também mais alta em $K$. marxianus que em $K$. lactis. Porém, ambas se mostraram menos estáveis que a esterase homóloga de Thermus thermophilus.

Ao final, foi possível verificar que a levedura Kluyveromyces marxianus pode ser utilizada como hospedeira na síntese de proteínas heterólogas. Além disso, possui virtudes fisiológicas que podem resultar em maiores produtividades em nível industrial, conforme amplamente demonstrado em vários trabalhos anteriores disponíveis na literatura. Com isso, este trabalho contribuiu para trazer à tona essa alternativa de hospedeiro, aumentando o espectro de leveduras além das já consagradas S. cerevisiae, $K$. lactis, $H$. polymorpha, $P$. pastoris, etc. 


\section{Sugestões para trabalhos futuros}

A seguir, encontram-se algumas sugestões para estudos futuros, que poderão contribuir para o aprofundamento do tema abordado nesta tese:

- Determinar o número de cópias dos plasmídeos de cada construção epissomal, tanto em K. marxianus quanto em K. lactis;

- Determinar a atividade de protease em cada fração celular da levedura;

- Determinar o peso exato de cada glicoproteína por espectometria de massa;

- Seqüenciar as cadeias de açúcares anexadas às proteínas por ambas as leveduras, para comparar seus mecanismos de glicosilação;

- Determinar os níveis de mRNA das duas proteínas e relacionar com os níveis de expressão, principalmente no caso da esterase, em que houve suspeita de degradação de peptídeos mal-formados;

- Realizar estudos estruturais nas esterases para detectar as diferenças que a enzima heteróloga apresenta em relação à homóloga e que eventualmente levaram à perda da termoestabilidade da primeira;

- Realizar mutações silenciosas na seqüência da esterase, alterando os códons raros, por outros comuns às leveduras e verificar se há alteração no nível de expressão;

- Realizar cultivos em batelada alimentada para que seja alcançada alta densidade celular. Testar a indução da expressão dos genes heterólogos nestas condições;

- Testar diferentes meios de cultura, de menor custo, para verificar a capacidade deste hospedeiro em expressar os genes heterólogos em situações mais próximas à realidade industrial. 
Referências Bibliográficas 
Alani, E., L. Cao, et al. A method for gene disruption that allows repeated use of URA3 selection in the construction of multiply disrupted yeast strains. Genetics, v.116, n.4, Aug, p.541-5. 1987.

Almeida, C., T. Branyik, et al. Continuous production of pectinase by immobilized yeast cells on spent grains. J Biosci Bioeng, v.96, n.6, p.513-8. 2003.

Al-Zuhair, S., F. W. Ling, et al. Proposed kinetic mechanism of the production of biodiesel from palm oil using lipase. Process Biochemistry, v.42, n.6, p.951-960. 2007.

Antoniukas, L., H. Grammel, et al. Production of hantavirus Puumala nucleocapsid protein in Saccharomyces cerevisiae for vaccine and diagnostics. J Biotechnol, v.124, n.2, Jul 13, p.347-62. 2006.

Apweiler, R., H. Hermjakob, et al. On the frequency of protein glycosylation, as deduced from analysis of the SWISS-PROT database. Biochim Biophys Acta, v.1473, n.1, Dec 6, p.4-8. 1999.

Arpigny, J. L. e K. E. Jaeger. Bacterial lipolytic enzymes: classification and properties. Biochem J, v.343 Pt 1, Oct 1, p.177-83. 1999.

Ball, M. M., A. Raynal, et al. Construction of efficient centromeric, multicopy and expression vectors for the yeast Kluyveromyces marxianus using homologous elements and the promoter of a purine-cytosine-like permease. $\underline{\mathrm{J} \text { Mol Microbiol }}$ Biotechnol, v.1, n.2, Nov, p.347-53. 1999.

Bao, J., K. Furumoto, et al. A kinetic study on air oxidation of glucose catalyzed by immobilized glucose oxidase for production of calcium gluconate. Biochem Eng $\mathrm{J}$, v.8, n.2, Sep, p.91-102.

Bartkeviciute, D., R. Siekstele, et al. Heterologous expression of the Kluyveromyces marxianus endopolygalacturonase gene (EPG1) using versatile autonomously replicating vector for a wide range of host. Enzyme Microb Technol, v.26, n.9-10, Jun 1, p.653-656. 2000.

Baudin, A., O. Ozier-Kalogeropoulos, et al. A simple and efficient method for direct gene deletion in Saccharomyces cerevisiae. Nucleic Acids Res, v.21, n.14, Jul 11, p.3329-30. 1993.

Becerra, M., S. D. Prado, et al. New secretory strategies for Kluyveromyces lactis beta-galactosidase. Protein Eng, v.14, n.5, May, p.379-86. 2001.

Beggs, J. D. Transformation of yeast by a replicating hybrid plasmid. Nature, v.275, n.5676, Sep 14, p.104-9. 1978.

Bellaver, L. H. 2003. Fisiologia da levedura Kluyveromyces marxianus CBS 6556 em termos da formação de etanol e de atividades enzimáticas em torno da glicose-6fosfato. 2003. Dissertação (Mestrado em Biotecnologia) - Escola Politécnica, Universidade de São Paulo, 2003. 
Bellaver, L. H., N. M. De Carvalho, et al. Ethanol formation and enzyme activities around glucose-6-phosphate in Kluyveromyces marxianus CBS 6556 exposed to glucose or lactose excess. FEMS Yeast Res, v.4, n.7, May, p.691-8. 2004.

Belloch, C., T. Fernandez-Espinar, et al. An analysis of inter- and intraspecific genetic variabilities in the Kluyveromyces marxianus group of yeast species for the reconsideration of the K. lactis taxon. Yeast, v.19, n.3, Feb, p.257-68. 2002.

Benz, I. e M. A. Schmidt. Never say never again: protein glycosylation in pathogenic bacteria. Mol Microbiol, v.45, n.2, Jul, p.267-76. 2002.

Berger, J. L., B. H. Lee, et al. Identification of new enzyme activities of several strains of Thermus species. Appl Microbiol Biotechnol, v.44, n.1-2, Dec, p.81-7. 1995.

Bergkamp, R. J., I. M. Kool, et al. Multiple-copy integration of the alpha-galactosidase gene from Cyamopsis tetragonoloba into the ribosomal DNA of Kluyveromyces lactis. Curr Genet, v.21, n.4-5, Apr, p.365-70. 1992.

Bergkamp, R. J., T. C. Bootsman, et al. Expression of an alpha-galactosidase gene under control of the homologous inulinase promoter in Kluyveromyces marxianus. Appl Microbiol Biotechnol, v.40, n.2-3, Nov, p.309-17. 1993.

Bergh, M. L., C. L. Cepko, et al. Expression of the Saccharomyces cerevisiae glycoprotein invertase in mouse fibroblasts: glycosylation, secretion, and enzymatic activity. Proc Natl Acad Sci U S A, v.84, n.11, Jun, p.3570-4. 1987.

Bianchi M. M., C. Falcone, et al. Transformation of the yeast Kluyveromyces lactis by new vectors derived from the $1.6 \mathrm{~mm}$ circular plasmid pKD1. Curr Genet, v.12, p.185-192. 1987.

Blanco, P., C. Sieiro, et al. Production of pectic enzymes in yeasts. FEMS Microbiol Lett, v.175, n.1, Jun 1, p.1-9. 1999.

Blank, L. M. e U. Sauer. TCA cycle activity in Saccharomyces cerevisiae is a function of the environmentally determined specific growth and glucose uptake rates. Microbiology, v.150, n.Pt 4, Apr, p.1085-93. 2004.

Boeke, J. D., F. Lacroute, et al. A positive selection for mutants lacking orotidine-5'phosphate decarboxylase activity in yeast: 5-fluoro-orotic acid resistance. Mol Gen Genet, v.197, n.2, p.345-6. 1984.

Bornscheuer, U. T. Microbial carboxyl esterases: classification, properties and application in biocatalysis. FEMS Microbiol Rev, v.26, n.1, Mar, p.73-81. 2002.

Branduardi, P., M. Valli, et al. The yeast Zygosaccharomyces bailii: a new host for heterologous protein production, secretion and for metabolic engineering applications. FEMS Yeast Res, v.4, n.4-5, Jan, p.493-504. 2004.

Brachmann, C. B., A. Davies, et al. Designer deletion strains derived from 
Saccharomyces cerevisiae S288C: a useful set of strains and plasmids for PCRmediated gene disruption and other applications. Yeast, v.14, n.2, Jan 30, p.115-32. 1998.

Buckholz, R. G. e M. A. Gleeson. Yeast systems for the commercial production of heterologous proteins. Biotechnology (N Y), v.9, n.11, Nov, p.1067-72. 1991.

Cai, X. P., J. Zhang, et al. Secretory expression of heterologous protein in Kluyveromyces cicerisporus. Applied Genetics and Molecular Biotechnology, v.67, p.364 - 369. 2005.

Chen, X., B. Gao, et al. [Expression and secretion of human interferon alpha $A$ in yeast Kluyveromyces lactis]. Yi Chuan Xue Bao, v.19, n.3, p.284-8. 1992.

Chen, X. J., M. Saliola, et al. Sequence organization of the circular plasmid pKD1 from the yeast Kluyveromyces drosophilarum. Nucleic Acids Res, v.14, n.11, Jun 11, p.4471-81. 1986.

Chen, X.J., M. M. Bianchi, et al. The host range of the pKD1-derived plasmids in yeast. Curr Genet, v.16, p.95-98. 1989.

Chiba, Y. e Y. Jigami. Production of humanized glycoproteins in bacteria and yeasts. Curr Opin Chem Biol, v.11, n.6, Dec, p.670-6. 2007.

Choi, Y. J., C. B. Miguez, et al. Characterization and heterologous gene expression of a novel esterase from Lactobacillus casei CL96. Appl Environ Microbiol, v.70, n.6, Jun, p.3213-21. 2004.

Chung, B. H., S. W. Nam, et al. Highly efficient secretion of heterologous proteins from Saccharomyces cerevisiae using inulinase signal peptides. Biotechnol Bioeng, v.49, n.4, Feb 20, p.473-9. 1996.

Clare, J. J., M. A. Romanos, et al. Production of mouse epidermal growth factor in yeast: high-level secretion using Pichia pastoris strains containing multiple gene copies. Gene, v.105, n.2, Sep 15, p.205-12. 1991.

Codon Usage Database. http://www.kazusa.or.jp/codon/ . Visitado: 20 de Setembro 20 de 2009.

Cox, H., D. Mead, et al. Constitutive expression of recombinant proteins in the methylotrophic yeast Hansenula polymorpha using the PMA1 promoter. Yeast, v.16, n.13, Sep 30, p.1191-203. 2000.

Crabtree, H. G. Observations on the carbohydrate metabolism of tumours. Biochem J, v.23, n.3, p.536-45. 1929.

Crognale, S., Pulci, V., Brozzoli, V., Petruccioli, M., Federici, F. Expression of Penicillium variabile P16 glucose oxidase gene in Pichia pastoris and characterization of the recombinant enzyme. Enz Microbial Technol, v.39, n.6, Oct, p.1230-1235. 2006. 
Cruz-Guerrero, A.; J. Olvera, J, et al. Inulinase-hyperproducing strains of Kluyveromyces sp. Isolated from aguamiel (Agave sp.) and pulque. W. J. Microbiol. Biotechnol. v.22, p.115-117. 2006

Daly, R. e M. T. Hearn. Expression of heterologous proteins in Pichia pastoris: a

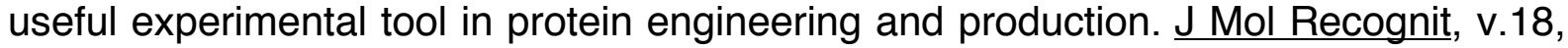
n.2, Mar-Apr, p.119-38. 2005.

Das, S., e C.P. Hollenberg. A high-frequency transformation system for the yeast Kluyveromyces lactis. Curr Genet. v. 6, p. 123-128. 1982

Das, S., E. Kellermann, et al. Transformation of Kluyveromyces fragilis. J Bacteriol, v.158, n.3, Jun, p.1165-7. 1984.

De Carvalho, N. M. B.. Crescimento e formação de metabólitos durante cultivos da levedura Kluyveromyces marxianus CBS 6556 em meio de cultura definido. 2005. Dissertação (Mestrado em Biotecnologia) - Instituto de Ciências Biomédicas, Universidade de São Paulo, 1995.

De Deken, R. H. The Crabtree effect: a regulatory system in yeast. J Gen Microbiol, v.44, n.2, Aug, p.149-56. 1966.

Derycke, D.G., E.J. Vandame. Production and properties of Aspergillus niger inulinase. J Chem Tech Biotechnol, v.34, p.45-51. 1984.

Domínguez, A., et al. Non-conventional yeasts as hosts for heterologous protein production. International Microbiol. v.1, p.131-142, 1998.

Dominguez, A., A. Sanroman, et al. Quantification of intra- and extra-cellular thermophilic lipase/esterase production by Thermus sp. Biotechnol Lett, v.26, n.9, May, p.705-8. 2004.

Dominguez, A., P. Fucinos, et al. Stimulation of novel thermostable extracellular lipolytic enzyme in cultures of Thermus sp. Enzyme Microb Technol, v.40, p.187-194. 2007.

Dujon, B., D. Sherman, et al. Genome evolution in yeasts. Nature, v.430, n.6995, Jul 1, p.35-44. 2004.

Eichenseer, H., M. C. Mathews, et al. Salivary glucose oxidase: multifunctional roles for helicoverpa zea? Arch Insect Biochem Physiol, v.42, n.1, Sep, p.99-109. 1999.

Empadinhas, N., L. Albuquerque, et al. The bacterium Thermus thermophilus, like hyperthermophilic archaea, uses a two-step pathway for the synthesis of mannosylglycerate. Appl Environ Microbiol, v.69, n.6, Jun, p.3272-9. 2003.

Etschmann, M. M., D. Sell, et al. Screening of yeasts for the production of the aroma compound 2-phenylethanol in a molasses-based medium. Biotechnol Lett, v.25, n.7, Apr, p.531-6. 2003. 
Falcone, C., M. Saliola, et al. Analysis of a 1.6-micron circular plasmid from the yeast Kluyveromyces drosophilarum: structure and molecular dimorphism. Plasmid, v.15, n.3, May, p.248-52. 1986.

Fatichenti, F. e E. Berardi. Kluyveromyces fragilis SS-437: an associatively-profiled thermotolerant yeast. Antonie Van Leeuwenhoek, v.53, n.2, p.119-24. 1987.

Fernandes, P. A., M. Sena-Esteves, et al. Characterization of the glyceraldehyde-3phosphate dehydrogenase gene family from Kluyveromyces marxianus--polymerase chain reaction-single-strand conformation polymorphism as a tool for the study of multigenic families. Yeast, v.11, n.8, Jun 30, p.725-33. 1995.

Ferreira, L. F., M. E. Taqueda, et al. Purification of glucose oxidase from Aspergillus niger by liquid-liquid cationic reversed micelles extraction. Biotechnol Prog, v.21, n.3, May-Jun, p.868-74. 2005.

Feng, Y. M., B. Y. Zhang, et al. Secretory Expression of Porcine Insulin Precursor in Kluyveromyces lactis and Its Conversion into Human Insulin. Sheng Wu Hua Xue Yu Sheng Wu Wu Li Xue Bao (Shanghai), v.29, n.2, p.129-134. 1997.

Fleer, R., X. J. Chen, et al. High-level secretion of correctly processed recombinant human interleukin-1 beta in Kluyveromyces lactis. Gene, v.107, n.2, Nov 15, p.28595. 1991.

Flores-Carreón, A., S. H. Hixson, et al. The processing of $\mathrm{N}$-linked glycans in yeast. Mutually exclusive steps in the processing of a Man6 derivative by yeast membrane preparations. J Biol Chem, v.265, n.2, Jan 15, p.754-9. 1990.

Fonseca, G. G. Investigação do metabolismo de Kluyveromyces marxianus utilizando substratos marcados com 13C. 2007. Tese (Doutorado em Biotecnologia) Instituto de Ciências Biomédicas, Universidade de São Paulo, 2007.

Fonseca, G. G., A. K. Gombert, et al. Physiology of the yeast Kluyveromyces marxianus during batch and chemostat cultures with glucose as the sole carbon source. FEMS Yeast Res, v.7, n.3, May, p.422-35. 2007.

Fonseca, G. G., E. Heinzle, et al. The yeast Kluyveromyces marxianus and its biotechnological potential. Appl Microbiol Biotechnol, Apr 22. 2008.

Frederick, K. R., J. Tung, et al. Glucose oxidase from Aspergillus niger. Cloning, gene sequence, secretion from Saccharomyces cerevisiae and kinetic analysis of a yeast-derived enzyme. J Biol Chem, v.265, n.7, Mar 5, p.3793-802. 1990.

Fuciños, P., C. M. Abadin, et al. Identification of extracellular lipases/esterases produced by Thermus thermophilus HB27: partial purification and preliminary biochemical characterisation. J Biotechnol, v.117, n.3, May 25, p.233-41. 2005.

Futcher, A. B. The 2 micron circle plasmid of Saccharomyces cerevisiae. Yeast, v.4, n.1, Mar, p.27-40. 1988. 
Gellissen, G. e C. P. Hollenberg. Application of yeasts in gene expression studies: a comparison of Saccharomyces cerevisiae, Hansenula polymorpha and Kluyveromyces lactis -- a review. Gene, v.190, n.1, Apr 29, p.87-97. 1997.

Gemmill, T. R. e R. B. Trimble. Overview of N- and O-linked oligosaccharide structures found in various yeast species. Biochim Biophys Acta, v.1426, n.2, Jan 6, p.227-37. 1999.

Giardina, P., G. Palmieri, et al. Protein and gene structure of a blue laccase from Pleurotus ostreatus1. Biochem J, v.341 ( Pt 3), Aug 1, p.655-63. 1999.

Gietz, R. D. e A. Sugino. New yeast-Escherichia coli shuttle vectors constructed with in vitro mutagenized yeast genes lacking six-base pair restriction sites. Gene, v.74, n.2, Dec 30, p.527-34. 1988.

Goff, C. G., D. T. Moir, et al. Expression of calf prochymosin in Saccharomyces cerevisiae. Gene, v.27, n.1, Jan, p.35-46. 1984.

González-Siso, M.I., E. Ramil, et al. Respirofermentative metabolism in Kluyveromyces lactis: ethanol production and the Crabtree effect. Enz Microb Technol, v.18, p.585-591. 1996.

Gonzalez-Siso, M. I., M. A. Freire-Picos, et al. Respirofermentative metabolism in Kluyveromyces lactis: Insights and perspectives. Enzyme Microb Technol, v.26, n.910, Jun 1, p.699-705. 2000.

Gouda, M. D., S. A. Singh, et al. Thermal inactivation of glucose oxidase. Mechanism and stabilization using additives. J Biol Chem, v.278, n.27, Jul 4, p.24324-33. 2003.

Groeneveld, P., A. H. Stouthamer, et al. Super life--how and why 'cell selection' leads to the fastest-growing eukaryote. Febs J, v.276, n.1, Jan, p.254-70. 2009.

Grootwassink, J.W.D., Hewitt, G.M. Inducible and constitutiveformation of bfructofuranosidase (inulase) in batch and continuous cultures of the yeastKluyveromyces marxianus. J Gen Microbiol, v.129, p.31-41. 1983

Hamilton, S. R. e T. U. Gerngross. Glycosylation engineering in yeast: the advent of fully humanized yeast. Curr Opin Biotechnol, v.18, n.5, Oct, p.387-92. 2007.

Haney, P., J. Konisky, et al. Structural basis for thermostability and identification of potential active site residues for adenylate kinases from the archaeal genus Methanococcus. Proteins, v.28, n.1, May, p.117-30. 1997.

Hari Krishna, S., T. Janardhan Reddy, et al. Simultaneous saccharification and fermentation of lignocellulosic wastes to ethanol using a thermotolerant yeast. Bioresour Technol, v.77, n.2, Apr, p.193-6. 2001.

Harman, G., C. Hayes, et al. Chitinolytic enzymes of Trichoderma harzianum: purification of chitobiosidase and endochitinase. Phytopathology, v.83, n.3, p.313318. 1993. 
Hellmuth, K., S. Pluschkell, et al. Optimization of glucose oxidase production by Aspergillus niger using genetic- and process-engineering techniques. Appl Microbiol Biotechnol, v.43, n.6, Nov, p.978-84. 1995.

Hensing, M. C., R. J. Rouwenhorst, et al. Physiological and technological aspects of large-scale heterologous-protein production with yeasts. Antonie Van Leeuwenhoek, v.67, n.3, p.261-79. 1995.

Hodgkins, M., D. Mead, et al. Expression of the glucose oxidase gene from Aspergillus niger in Hansenula polymorpha and its use as a reporter gene to isolate regulatory mutations. Yeast, v.9, n.6, Jun, p.625-35. 1993.

Hong, J., Y. Wang, et al. Construction of thermotolerant yeast expressing thermostable cellulase genes. J Biotechnol, v.130, n.2, Jun 15, p.114-23. 2007.

Hsieh, P., M. R. Rosner, et al. Selective cleavage by endo-beta-Nacetylglucosaminidase $\mathrm{H}$ at individual glycosylation sites of Sindbis virion envelope glycoproteins. J Biol Chem, v.258, n.4, Feb 25, p.2555-61. 1983.

Iwata, T., R. Tanaka, et al. Efficient secretion of human lysozyme from the yeast, Kluyveromyces lactis. Biotechnol Lett, v.26, n.23, Dec, p.1803-8. 2004.

Ito, H., Y. Fukuda, et al. Transformation of intact yeast cells treated with alkali cations. J Bacteriol, v.153, n.1, Jan, p.163-8. 1983.

Jars, M. U., S. Osborn, et al. N- and O-glycosylation and phosphorylation of the bar secretion leader derived from the barrier protease of Saccharomyces cerevisiae. $\underline{\mathrm{J}}$ Biol Chem, v.270, n.42, Oct 20, p.24810-7. 1995.

Karshikoff, A. e R. Ladenstein. Proteins from thermophilic and mesophilic organisms essentially do not differ in packing. Protein Eng, v.11, n.10, Oct, p.867-72. 1998.

Kiers, J., A. M. Zeeman, et al. Regulation of alcoholic fermentation in batch and chemostat cultures of Kluyveromyces lactis CBS 2359. Yeast, v.14, n.5, Mar 30, p.459-69. 1998.

Kim, M. W., S. K. Rhee, et al. Characterization of N-linked oligosaccharides assembled on secretory recombinant glucose oxidase and cell wall mannoproteins from the methylotrophic yeast Hansenula polymorpha. Glycobiology, v.14, n.3, Mar, p.243-51. 2004.

Kim, S. e S. B. Lee. Rare codon clusters at 5'-end influence heterologous expression of archaeal gene in Escherichia coli. Protein Expr Purif, v.50, n.1, Nov, p.49-57. 2006.

Kim, S. Y., J. H. Sohn, et al. Variations in protein glycosylation in Hansenula polymorpha depending on cell culture stage. J Microbiol Biotechnol, v.17, n.12, Dec, p.1949-54. 2007.

Kriechbaum, M., H. J. Heilmann, et al. Cloning and DNA sequence analysis of the 
glucose oxidase gene from Aspergillus niger NRRL-3. FEBS Lett, v.255, n.1, Sep 11, p.63-6. 1989.

Kobata, A. Structures and functions of the sugar chains of glycoproteins. Eur J Biochem, v.209, n.2, Oct 15, p.483-501. 1992.

Kohen, A., T. Jonsson, et al. Effects of protein glycosylation on catalysis: changes in hydrogen tunneling and enthalpy of activation in the glucose oxidase reaction. Biochemistry, v.36, n.9, Mar 4, p.2603-11. 1997.

Kooistra, R., P. J. Hooykaas, et al. Efficient gene targeting in Kluyveromyces lactis. Yeast, v.21, n.9, Jul 15, p.781-92. 2004.

Kumar, S., C. J. Tsai, et al. Factors enhancing protein thermostability. Protein Eng, v.13, n.3, Mar, p.179-91. 2000.

Kurtzman, C.P.; Fell, J.W. The yeasts - a taxonomic study. 4 ed. New York: Elsevier. 1998.

Kusai, K., I. Sekuzu, et al. Crystallization of glucose oxidase from Penicillium amagasakiense. Biochim Biophys Acta, v.40, Jun 3, p.555-7. 1960.

Kushi, R. T., R. Monti, et al. Production, purification and characterization of an extracellular inulinase from Kluyveromyces marxianus var. bulgaricus. Journal of Industrial Microbiology \& Biotechnology, v.25, n.2, Aug, p.63-69. 2000.

Lachance, M. A. Current status of Kluyveromyces systematics. FEMS Yeast Res, v.7, n.5, Aug, p.642-5. 2007.

Laemmli, U. K. Cleavage of structural proteins during the assembly of the head of bacteriophage T4. Nature, v.227, n.5259, Aug 15, p.680-5. 1970.

Lagarde, D., H. K. Nguyen, et al. High-throughput screening of thermostable esterases for industrial bioconversions. Org Process Res Develop. v.6, n.4, p.441-5. 2002.

Lages, F., Silva-Graça, M., Lucas, C. Active glycerol uptake is a mechanism underlying halotolerance in yeasts: a study of 42 species. Microbiol, v.145, p.25772585. 1999

Lee, F. W. e N. A. Da Silva. Sequential delta-integration for the regulated insertion of cloned genes in Saccharomyces cerevisiae. Biotechnol Prog, v.13, n.4, Jul-Aug, p.368-73. 1997.

Lehle, L., A. Eiden, et al. Glycoprotein biosynthesis in Saccharomyces cerevisiae: ngd29, an N-glycosylation mutant allelic to och1 having a defect in the initiation of outer chain formation. FEBS Lett, v.370, n.1-2, Aug 14, p.41-5. 1995.

Leiter, E., F. Marx, et al. Penicillium chrysogenum glucose oxidase -- a study on its antifungal effects. J Appl Microbiol, v.97, n.6, p.1201-9. 2004. 
Lis, H. e N. Sharon. Protein glycosylation. Structural and functional aspects. Eur J Biochem, v.218, n.1, Nov 15, p.1-27. 1993.

Liu, J. e J. Wang. A Novel Improved Design for the First-generation Glucose Biosensor. Food technol biotechnol, v.39, n.1, 2001, p.55-58. 2001.

Lommel, M., M. Bagnat, et al. Aberrant processing of the WSC family and Mid2p cell surface sensors results in cell death of Saccharomyces cerevisiae O-mannosylation mutants. Mol Cell Biol, v.24, n.1, Jan, p.46-57. 2004.

Lommel, M. e S. Strahl. Protein O-Mannosylation: Conserved from Bacteria to Humans. Glycobiology, May 9. 2009.

Longhi, L. G., D. J. Luvizetto, et al. A growth kinetic model of Kluyveromyces

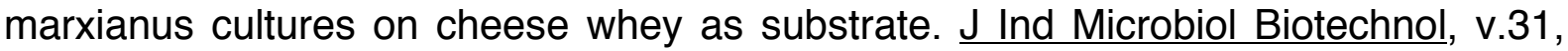
n.1, Jan, p.35-40. 2004.

Luque, R., M. Orejas, et al. $\mathrm{pH}$ control of the production of recombinant glucose oxidase in Aspergillus niger. J Appl Microbiol, v.97, p.332-337. 2004.

Macauley-Patrick, S., M. L. Fazenda, et al. Heterologous protein production using the

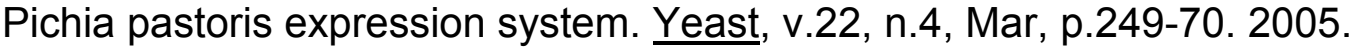

Madzak, C., C. Gaillardin, et al. Heterologous protein expression and secretion in the

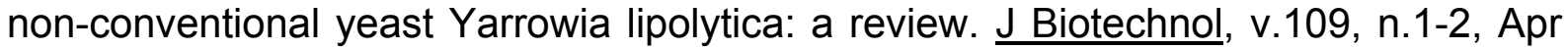
8, p.63-81. 2004.

Madzak, C., L. Otterbein, et al. Heterologous production of a laccase from the basidiomycete Pycnoporus cinnabarinus in the dimorphic yeast Yarrowia lipolytica. FEMS Yeast Res, v.5, n.6-7, Apr, p.635-46. 2005.

Mahmoud MM, Kosikowski FV. Alcohol and single cell protein production by Kluyveromyces in concentrated whey permeates with reduced ash. J. Dairy Sci v.65, p.2082-2087. 1982.

Malherbe, D. F., M. Du Toit, et al. Expression of the Aspergillus niger glucose oxidase gene in Saccharomyces cerevisiae and its potential applications in wine production. Appl Microbiol Biotechnol, v.61, n.5-6, Jun, p.502-11. 2003.

Marks, N. E., A. S. Grandison, et al. Challenge testing of the lactoperoxidase system in pasteurized milk. J Appl Microbiol, v.91, n.4, Oct, p.735-41. 2001.

Mattanovich, D., B. Gasser, et al. Stress in recombinant protein producing yeasts. $\underline{J}$ Biotechnol, v.113, n.1-3, Sep 30, p.121-35. 2004.

Mazutti, M., J.P. Bender, et al. Optimization of inulinase production by solid-state fermentation using sugarcane bagasse as substrate. Enz Microbial Technol v. 39, p. 56-59. 2005. 
Medeiros, A.B.P.; Pandey, A.; Christen, P.; Fontoura, P.S.G.; Freitas, R.J.S.; Soccol, C.R. Aroma compounds produced by Kluyveromyces marxianus in solid state fermentation on a packed bed column bioreactor. World J. Microbiol. Biotechnol. n.17, p.761-771. 2001.

Merico, A., D. Capitanio, et al. How physiological and cultural conditions influence heterologous protein production in Kluyveromyces lactis. J Biotechnol, v.109, n.1-2, Apr 8, p.139-46. 2004.

Mescher, M. F., J. L. Strominger, et al. Protein and carbohydrate composition of the cell envelope of Halobacterium salinarium. J Bacteriol, v.120, n.2, Nov, p.945-54. 1974.

Miller, K. D., J. Weaver-Feldhaus, et al. Production, purification, and characterization of human scFv antibodies expressed in Saccharomyces cerevisiae, Pichia pastoris, and Escherichia coli. Protein Expr Purif, v.42, n.2, Aug, p.255-67. 2005.

Mirón, J.; González, M. P., et al. Diauxic production of glucose oxidase by Aspergillus niger in submerged culture: a dynamic model. Enz Microb Technol. v.31, n.5, Oct, p.615-20. 2002.

Moehle, C. M., M. W. Aynardi, et al. Protease B of Saccharomyces cerevisiae: isolation and regulation of the PRB1 structural gene. Genetics, v.115, n.2, Feb, p.255-63. 1987.

Moens, S. e J. Vanderleyden. Glycoproteins in prokaryotes. Arch Microbiol, v.168, n.3, Sep, p.169-75. 1997.

Monti, D., E. E. Ferrandi, et al. Purification and characterization of the enantioselective esterase from Kluyveromyces marxianus CBS 1553. J Biotechnol, v.133, n.1, Jan 1, p.65-72. 2008.

Moore, J. C. e F. H. Arnold. Directed evolution of a para-nitrobenzyl esterase for aqueous-organic solvents. Nat Biotechnol, v.14, n.4, Apr, p.458-67. 1996.

Mulder, W., I. H. Scholten, et al. Carbon catabolite regulation of transcription of nuclear genes coding for mitochondrial proteins in the yeast Kluyveromyces lactis. Curr Genet, v.28, n.3, Aug, p.267-73. 1995.

Müller, D. Biochem. Z., v.199, p.136. 1928

Muller, S., T. Sandal, et al. Comparison of expression systems in the yeasts Saccharomyces cerevisiae, Hansenula polymorpha, Klyveromyces lactis, Schizosaccharomyces pombe and Yarrowia lipolytica. Cloning of two novel promoters from Yarrowia lipolytica. Yeast, v.14, n.14, Oct, p.1267-83. 1998.

Nakamura, T.; Ogata, Y.; Hamada, S.; Ohta, K. Ethanol production from Jerusalem artichoke tubers by Aspergillus niger and Saccharomyces cerevisiae. J. Ferm. Bioeng. v.81, p.564-566. 1996. 
Nakatsukasa, K., S. Okada, et al. Roles of O-mannosylation of aberrant proteins in reduction of the load for endoplasmic reticulum chaperones in yeast. $\mathrm{J}$ Biol Chem, v.279, n.48, Nov 26, p.49762-72. 2004.

Newman, J. D. e S. J. Setford. Enzymatic biosensors. Mol Biotechnol, v.32, n.3, Mar, p.249-68. 2006.

Niehaus, F., C. Bertoldo, et al. Extremophiles as a source of novel enzymes for industrial application. Appl Microbiol Biotechnol, v.51, n.6, Jun, p.711-29. 1999.

Nissen, T. L., U. Schulze, et al. Flux distributions in anaerobic, glucose-limited continuous cultures of Saccharomyces cerevisiae. Microbiology, v.143 ( Pt 1), Jan, p.203-18. 1997.

Nissen, T. L., C. W. Hamann, et al. Anaerobic and aerobic batch cultivations of Saccharomyces cerevisiae mutants impaired in glycerol synthesis. Yeast, v.16, n.5, Mar 30, p.463-74. 2000.

Nonklang, S., B. M. Abdel-Banat, et al. High-temperature ethanol fermentation and transformation with linear DNA in the thermotolerant yeast Kluyveromyces marxianus DMKU3-1042. Appl Environ Microbiol, v.74, n.24, Dec, p.7514-21. 2008.

Olsson L., J. Nielsen. On-line and in situ monitoring of biomass in submerged cultivations. TIBTECH v.15, p.517-522. 1997.

Overkamp, K. M., B. M. Bakker, et al. Metabolic engineering of glycerol production in Saccharomyces cerevisiae. Appl Environ Microbiol, v.68, n.6, Jun, p.2814-21. 2002.

Pantazaki, A. A., A. A. Pritsa, et al. Biotechnologically relevant enzymes from Thermus thermophilus. Appl Microbiol Biotechnol, v.58, n.1, Jan, p.1-12. 2002.

Parekh, S., Margaritis, A. Inulinase ( $\beta$-fructofuranosidase) production by Kluyveromyces marxianus in batch culture. Appl Microbiol Biotechnol v.22, p.446448. 1985.

Park, E. H., Y. M. Shin, et al. Expression of glucose oxidase by using recombinant yeast. J Biotechnol, v.81, n.1, Jul 28, p.35-44. 2000.

Park, J. P. e J. W. Yun. Utilization of chicory roots for microbial endoinulinase production. Lett Appl Microbiol, v.33, n.3, Sep, p.183-7. 2001.

Parolin, C., A. D. Corso, et al. Heterologous production of five Hepatitis C virusderived antigens in three Saccharomyces cerevisiae host strains. J Biotechnol, v.120, n.1, Oct 17, p.46-58. 2005.

Pecota, D. C. e N. A. Da Silva. Evaluation of the tetracycline promoter system for regulated gene expression in Kluyveromyces marxianus. Biotechnol Bioeng, v.92, n.1, Oct 5, p.117-23. 2005.

Pecota, D. C., V. Rajgarhia, et al. Sequential gene integration for the engineering of 


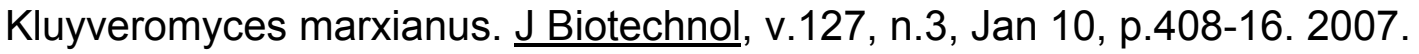

Pessoa Jr., A.; R. Hartmann, R., et al. Recovery of extracellular inulinase by expanded bed adsorption. J. Biotechnol. v.51, p. $89-95.1996$

Pontecorvo, G., J. A. Roper, et al. The genetics of Aspergillus nidulans. Adv Genet, v.5, p.141-238. 1953.

Porro, D., M. Sauer, et al. Recombinant protein production in yeasts. Mol Biotechnol, v.31, n.3, Nov, p.245-59. 2005.

Postma, E., C. Verduyn, et al. Enzymic analysis of the crabtree effect in glucoselimited chemostat cultures of Saccharomyces cerevisiae. Appl Environ Microbiol, v.55, n.2, Feb, p.468-77. 1989.

Raimondi, S., D. Uccelletti, et al. Characterization of the superoxide dismutase SOD1 gene of Kluyveromyces marxianus L3 and improved production of SOD activity. Appl Microbiol Biotechnol, v.77, n.6, Jan, p.1269-77. 2008.

Rao, C. N., P. Reddy, et al. Extracellular matrix-associated serine protease inhibitors (Mr 33,000, 31,000, and 27,000) are single-gene products with differential glycosylation: cDNA cloning of the 33-kDa inhibitor reveals its identity to tissue factor pathway inhibitor-2. Arch Biochem Biophys, v.335, n.1, Nov 1, p.82-92. 1996.

Raschke, W. C. e C. E. Ballou. Characterization of a yeast mannan containing Nacetyl-D-glucosamine as an immunochemical determinant. Biochemistry, v.11, n.20, Sep 26, p.3807-16. 1972.

Ribeiro, O., A. K. Gombert, et al. Application of the Cre-loxP system for multiple gene disruption in the yeast Kluyveromyces marxianus. J Biotechnol, v.131, n.1, Aug 1, p.20-6. 2007.

Rocha, T. L., G. Paterson, et al. Expression and secretion of recombinant ovine betalactoglobulin in Saccharomyces cerevisiae and Kluyveromyces lactis. Biochem J, v.313 ( Pt 3), Feb 1, p.927-32. 1996.

Roitsch, T. e L. Lehle. Structural requirements for protein N-glycosylation. Influence of acceptor peptides on cotranslational glycosylation of yeast invertase and sitedirected mutagenesis around a sequon sequence. Eur J Biochem, v.181, n.2, May 1, p.525-9. 1989.

Romanos, M. A., C. A. Scorer, et al. Foreign gene expression in yeast: a review. Yeast, v.8, n.6, Jun, p.423-88. 1992.

Rouwenhorst, R. J., L. E. Visser, et al. Production, Distribution, and Kinetic Properties of Inulinase in Continuous Cultures of Kluyveromyces marxianus CBS 6556. Appl Environ Microbiol, v.54, n.5, May, p.1131-1137. 1988.

Rua, M. L., C. Schmidt-Dannert, et al. Thermoalkalophilic lipase of Bacillus thermocatenulatus large-scale production, purification and properties: aggregation 
behaviour and its effect on activity. J Biotechnol, v.56, n.2, Aug 11, p.89-102. 1997.

Sadeghi, M., H. Naderi-Manesh, et al. Effective factors in thermostability of thermophilic proteins. Biophys Chem, v.119, n.3, Feb 1, p.256-70. 2006.

Sagt, C. M., B. Kleizen, et al. Introduction of an $\mathrm{N}$-glycosylation site increases secretion of heterologous proteins in yeasts. Appl Environ Microbiol, v.66, n.11, Nov, p.4940-4. 2000.

Sakai, A., Y. Shimizu, et al. Isolation and characterization of mutants which show an oversecretion phenotype in Saccharomyces cerevisiae. Genetics, v.119, n.3, Jul, p.499-506. 1988.

Salgueiro, S. P., I. Sa-Correia, et al. Ethanol-Induced Leakage in Saccharomyces cerevisiae: Kinetics and Relationship to Yeast Ethanol Tolerance and Alcohol Fermentation Productivity. Appl Environ Microbiol, v.54, n.4, Apr, p.903-909. 1988.

Sambrook, J., D.W. Russel. Molecular Cloning: A laboratory manual. Cold Spring Harbor Laboratory Press, New York, 2001.

Schmidt-Dannert, C., M. L. Rua, et al. Thermoalkalophilic lipase of Bacillus thermocatenulatus. I. molecular cloning, nucleotide sequence, purification and some properties. Biochim Biophys Acta, v.1301, n.1-2, May 31, p.105-14. 1996.

Schwan, R. F., R. M. Cooper, et al. Endopolygalacturonase secretion by Kluyveromyces marxianus and other cocoa pulp-degrading yeasts Enzyme Microb Technol, v.21, p.234 - 244. 1997.

Sentandreu, R. e D. H. Northcote. The structure of a glycopeptide isolated from the yeast cell wall. Biochem J, v.109, n.3, Sep, p.419-32. 1968.

Shin, K. S., H. D. Youn, et al. Purification and characterisation of D-glucose oxidase from white-rot fungus Pleurotus ostreatus. Eur J Biochem, v.215, n.3, Aug 1, p.74752. 1993.

Siekstele, R., D. Bartkeviciute, et al. Cloning, targeted disruption and heterologous expression of the Kluyveromyces marxianus endopolygalacturonase gene (EPG1). Yeast, v.15, n.4, Mar 15, p.311-22. 1999.

Singh, R. S., B. S. Sooch, et al. Optimization of medium and process parameters for the production of inulinase from a newly isolated Kluyveromyces marxianus YS-1. Bioresour Technol, v.98, n.13, Sep, p.2518-25. 2007.

Sisak, C., Csanádi, Z., Rónay, E., Szajáni, B. Elimination of glucose in egg white using immobilized glucose oxidase. Enz Microbial Technol, v. 39, n.5, Sep 4, p. 1002-7. 2006.

Souza Jr, C.G., Morais Jr, M.A. The use of the replicating pDblet plasmid as a cloning vector with enhanced stability in Kluyveromyces marxianus. Biotechnol Lett. v.22, p.43-45. 2000. 
Spiro, R. G. Protein glycosylation: nature, distribution, enzymatic formation, and disease implications of glycopeptide bonds. Glycobiology, v.12, n.4, Apr, p.43R-56R. 2002.

Stasyk, O. G., M. M. Maidan, et al. Identification of hexose transporter-like sensor HXS1 and functional hexose transporter HXT1 in the methylotrophic yeast Hansenula polymorpha. Eukaryot Cell, v.7, n.4, Apr, p.735-46. 2008.

Strahl-Bolsinger, S., M. Gentzsch, et al. Protein O-mannosylation. Biochim Biophys Acta, v.1426, n.2, Jan 6, p.297-307. 1999.

Strasser, A. W., R. Selk, et al. Analysis of the alpha-amylase gene of Schwanniomyces occidentalis and the secretion of its gene product in transformants of different yeast genera. Eur J Biochem, v.184, n.3, Oct 1, p.699-706. 1989.

Suárez-Castillo, I. D. 2004. Relatório de Pós-Doutorado. Universidade de São Paulo, Fundação de Amparo à Pesquisa do Estado de São Paulo. 2004.

Swoboda, B. E. e V. Massey. Purification and Properties of the Glucose Oxidase from Aspergillus Niger. J Biol Chem, v.240, May, p.2209-15. 1965.

Thomassen, Y. E., A. J. Verkleij, et al. Specific production rate of VHH antibody fragments by Saccharomyces cerevisiae is correlated with growth rate, independent of nutrient limitation. J Biotechnol, v.118, n.3, Aug 22, p.270-7. 2005.

Tokunaga, M., M. Ishibashi, et al. Secretion of mouse alpha-amylase from Kluyveromyces lactis. Yeast, v.13, n.8, Jun 30, p.699-706. 1997.

Trimble, R. B., F. Maley, et al. GlycoProtein biosynthesis in yeast. protein conformation affects processing of high mannose oligosaccharides on carboxypeptidase $\mathrm{Y}$ and invertase. J Biol Chem, v.258, n.4, Feb 25, p.2562-7. 1983.

Tsuge, H., O. Natsuaki, et al. Purification, properties, and molecular features of glucose oxidase from Aspergillus niger. J Biochem, v.78, n.4, Oct, p.835-43. 1975.

Van den Berg, J. A., et al. Kluyveromyces as a host for heterologous gene expression: Expression and secretion of prochymosin. Biotechnology. n. 8, p. 135139. 1990.

Van Gerpen, J. Biodiesel processing and production. Fuel Processing Technology, v.86, p.1097 - 1107. 2005.

Van Hoek, P., J. P. Van Dijken, et al. Effect of specific growth rate on fermentative capacity of baker's yeast. Appl Environ Microbiol, v.64, n.11, Nov, p.4226-33. 1998.

Van Ooyen, A. J., P. Dekker, et al. Heterologous protein production in the yeast Kluyveromyces lactis. FEMS Yeast Res, v.6, n.3, May, p.381-92. 2006.

Verger, R. Interfacial activation of lipases: facts and artefacts. Tibtech v.15, p.32-38. 1997. 
Verduyn, C., A. H. Stouthamer, et al. A theoretical evaluation of growth yields of yeasts. Antonie Van Leeuwenhoek, v.59, n.1, Jan, p.49-63. 1991.

Verduyn, C., E. Postma, et al. Effect of benzoic acid on metabolic fluxes in yeasts: a continuous-culture study on the regulation of respiration and alcoholic fermentation. Yeast, v.8, n.7, Jul, p.501-17. 1992.

Vogt, G. e P. Argos. Protein thermal stability: hydrogen bonds or internal packing? Fold Des, v.2, n.4, p.S40-6. 1997.

Wacker, M., D. Linton, et al. N-linked glycosylation in Campylobacter jejuni and its functional transfer into E. coli. Science, v.298, n.5599, Nov 29, p.1790-3. 2002.

Wang, Z. X., J. Zhuge, et al. Glycerol production by microbial fermentation: a review. Biotechnol Adv, v.19, n.3, Jun, p.201-23. 2001.

Wang, Y. C., L. L. Chuang, et al. Sequential cloned gene integration in the yeast Kluyveromyces lactis. Appl Microbiol Biotechnol, v.62, n.5-6, Oct, p.523-7. 2003.

Wildt, S. e T. U. Gerngross. The humanization of N-glycosylation pathways in yeast. Nat Rev Microbiol, v.3, n.2, Feb, p.119-28. 2005.

Wilson, R., Turner, A. P. F. Glucose Oxidase: an ideal enzyme. Biosens Bioelectron, v.7, n.3, p. 165-185. 1992.

Witt, S., M. Singh, et al. Structural and kinetic properties of nonglycosylated recombinant Penicillium amagasakiense glucose oxidase expressed in Escherichia coli. Appl Environ Microbiol, v.64, n.4, Apr, p.1405-11. 1998.

Wohlfahrt, G., S. Witt, et al. 1.8 and 1.9 A resolution structures of the Penicillium amagasakiense and Aspergillus niger glucose oxidases as a basis for modelling substrate complexes. Acta Crystallogr D Biol Crystallogr, v.55, n.Pt 5, May, p.969-77. 1999.

Wolff, A. M. e J. Arnau. Cloning of glyceraldehyde-3-phosphate dehydrogenaseencoding genes in Mucor circinelloides (Syn. racemosus) and use of the gpd1 promoter for recombinant protein production. Fungal Genet Biol, v.35, n.1, Feb, p.219. 2002.

Wong, C. M., K. H. Wong, et al. Glucose oxidase: natural occurrence, function, properties and industrial applications. Appl Microbiol Biotechnol, v.78, n.6, Apr, p.927-38. 2008.

Yu, R.J.; Scott, E.V. Method of using gluconic acid or gluconolactone for treating wrinkles. US Patent 5,677,340. 1997.

Zeeman, A. M., M. A. Luttik, et al. Impaired growth on glucose of a pyruvate dehydrogenase-negative mutant of Kluyveromyces lactis is due to a limitation in mitochondrial acetyl-coenzyme A uptake. FEMS Microbiol Lett, v.177, n.1, Aug 1, 
p.23-8. 1999.

Zeeman, A. M. e H. Y. Steensma. The acetyl co-enzyme A synthetase genes of Kluyveromyces lactis. Yeast, v.20, n.1, Jan 15, p.13-23. 2003.

Zeikus, J. G., C. Vieille, et al. Thermozymes: biotechnology and structure-function relationships. Extremophiles, v.2, n.3, Aug, p.179-83. 1998.

Zia, M. A., Khalil-Ur-Rahman, et al. Thermal characterization of purified glucose oxidase from a newly isolated Aspergillus niger UAF-1. Journal of Clinical Biochemistry and Nutrition, v.41, n.2, Sep, p.132-138. 2007a.

Zia, M. A., Khalil-Ur-Rahman, et al. Thermal characterization of hyperproduced glucose oxidase from Aspergillus niger BCG-5 mutant strain. 2007 leee/lcme International Conference on Complex Medical Engineering, Vols 1-4, p.1950-1955 2018. 2007b.

Zitomer, R. S. e B. D. Hall. Yeast cytochrome c messenger RNA. In vitro translation and specific immunoprecipitation of the CYC1 gene product. $\mathrm{J}$ Biol Chem, v.251, n.20, Oct 25, p.6320-6. 1976.

Zock, J., C. Cantwell, et al. The Bacillus subtilis pnbA gene encoding p-nitrobenzyl esterase: cloning, sequence and high-level expression in Escherichia coli. Gene, v.151, n.1-2, Dec 30, p.37-43. 1994. 
Apêndices 


\section{APÊNDICE A - GRÁFICOS DAS CINÉTICAS DE CRESCIMENTO DE}

\section{K. marxianus E K. lactis}

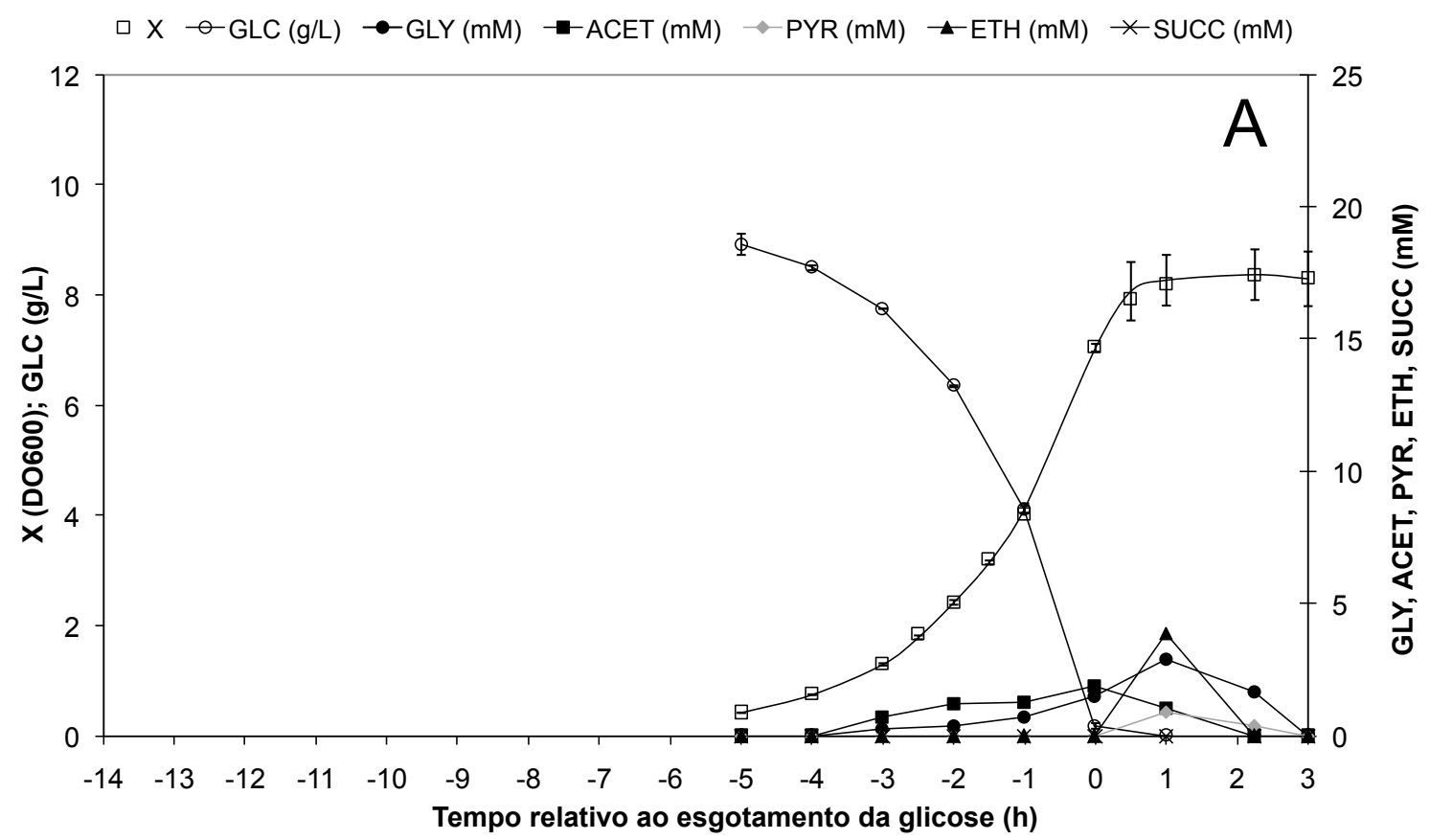

$\square \mathrm{X} \rightarrow \mathrm{GLC}(\mathrm{g} / \mathrm{L}) \rightarrow \mathrm{GLY}(\mathrm{mM}) \rightarrow \mathrm{ACET}(\mathrm{mM}) \rightarrow \mathrm{PYR}(\mathrm{mM}) \rightarrow \mathrm{ETH}(\mathrm{mM}) \quad$ - $\mathrm{SUCC}(\mathrm{mM})$

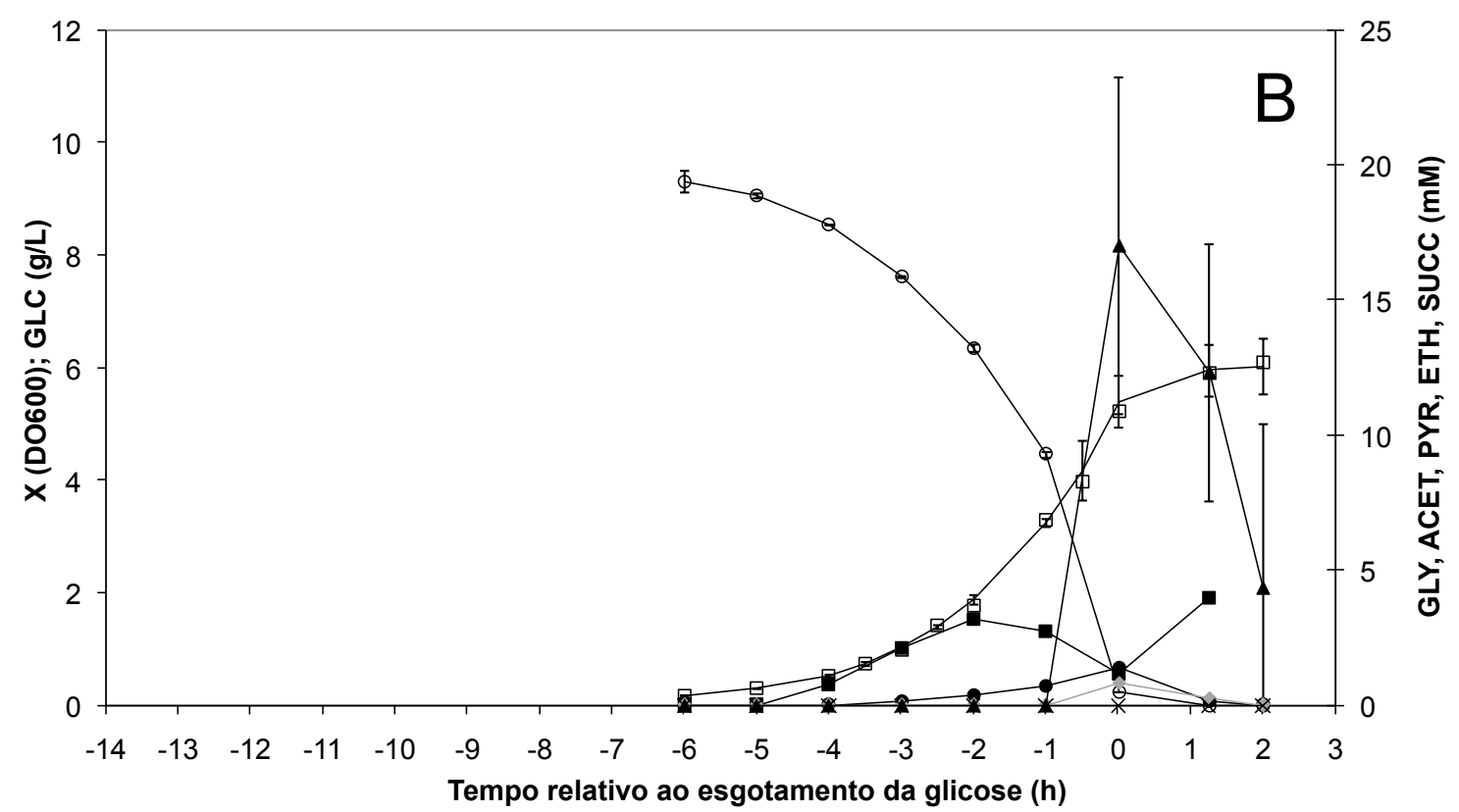

Figura A.1. Curvas de crescimento e formação de metabólitos de (A) K. marxianus CBS 6556 e (B) K. marxianus CBS 397 utilizando glicose $(10 \mathrm{~g} / \mathrm{L})$ como fonte de carbono a $30{ }^{\circ} \mathrm{C}$. Legenda: $(\mathrm{X})$ concentração celular (Absorbância a $600 \mathrm{~nm}$ ); (GLC) glicose (g/L); (GLY, ACET, PYR, ETH, SUCC) glicerol, acetato, piruvato, etanol, succinato $(\mathrm{mM})$, respectivamente. Os pontos apresentados são os valores médios determinados a partir de dois cultivos isolados. 


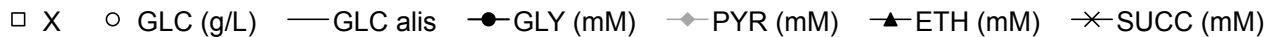

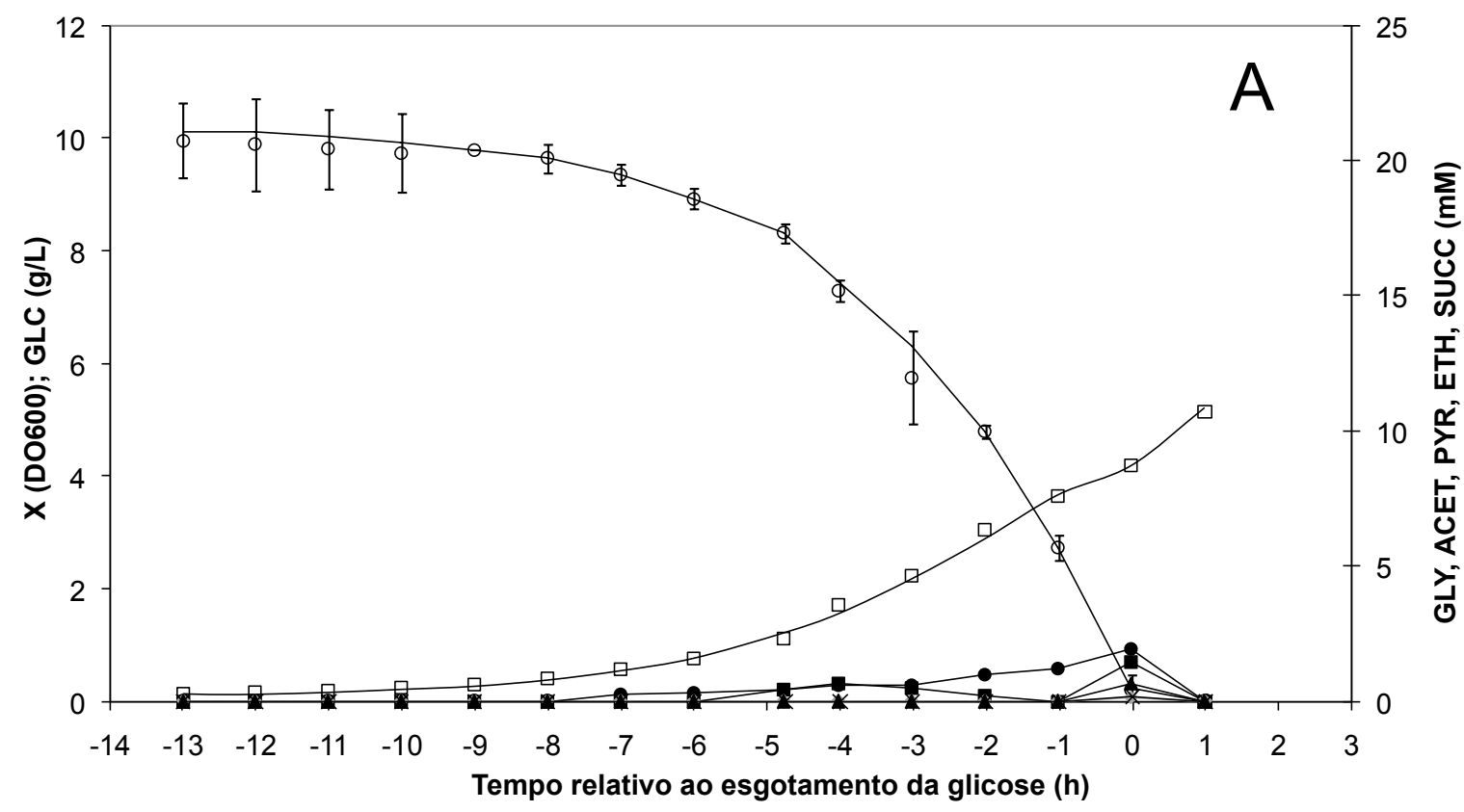

$\square \mathrm{X} \circ \mathrm{GLC}(\mathrm{g} / \mathrm{L}) \longrightarrow \mathrm{GLC}$ alis $\rightarrow$ ACET $(\mathrm{mM}) \rightarrow \mathrm{PYR}(\mathrm{mM}) \multimap \mathrm{ETH}(\mathrm{mM}) \quad$ SUCC $(\mathrm{mM})$

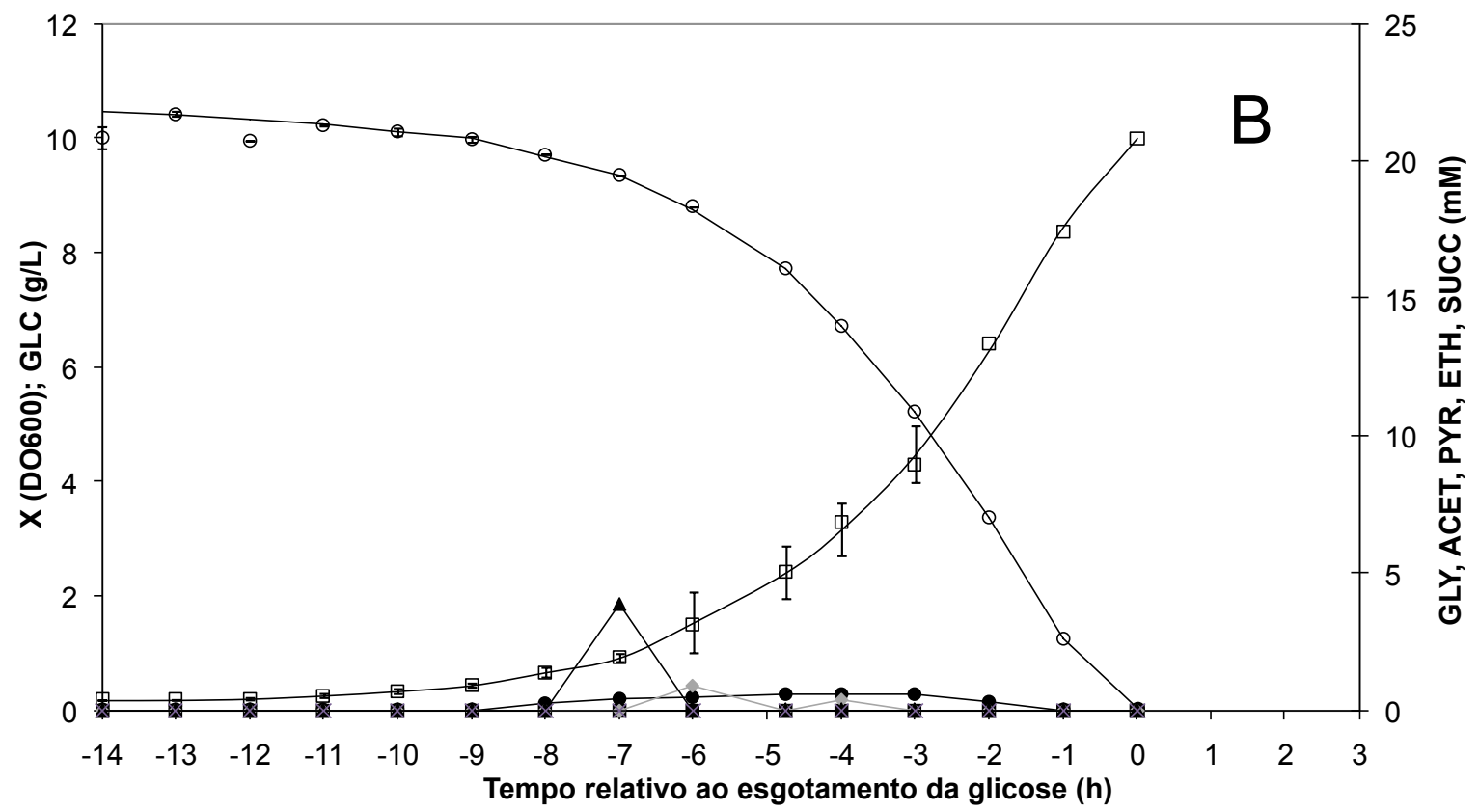

Figura A.2. Curvas de crescimento e formação de metabólitos de (A) K. marxianus CBS 712 e (B) K. lactis CBS 2359 utilizando glicose $(10 \mathrm{~g} / \mathrm{L})$ como fonte de carbono a $30^{\circ} \mathrm{C}$. Legenda: $(X)$ concentração celular (Absorbância a $600 \mathrm{~nm}$ ); (GLC) glicose (g/L); (GLY, ACET, PYR, ETH, SUCC) glicerol, acetato, piruvato, etanol, succinato $(\mathrm{mM})$, respectivamente. Os pontos apresentados são os valores médios determinados a partir de dois cultivos isolados. 

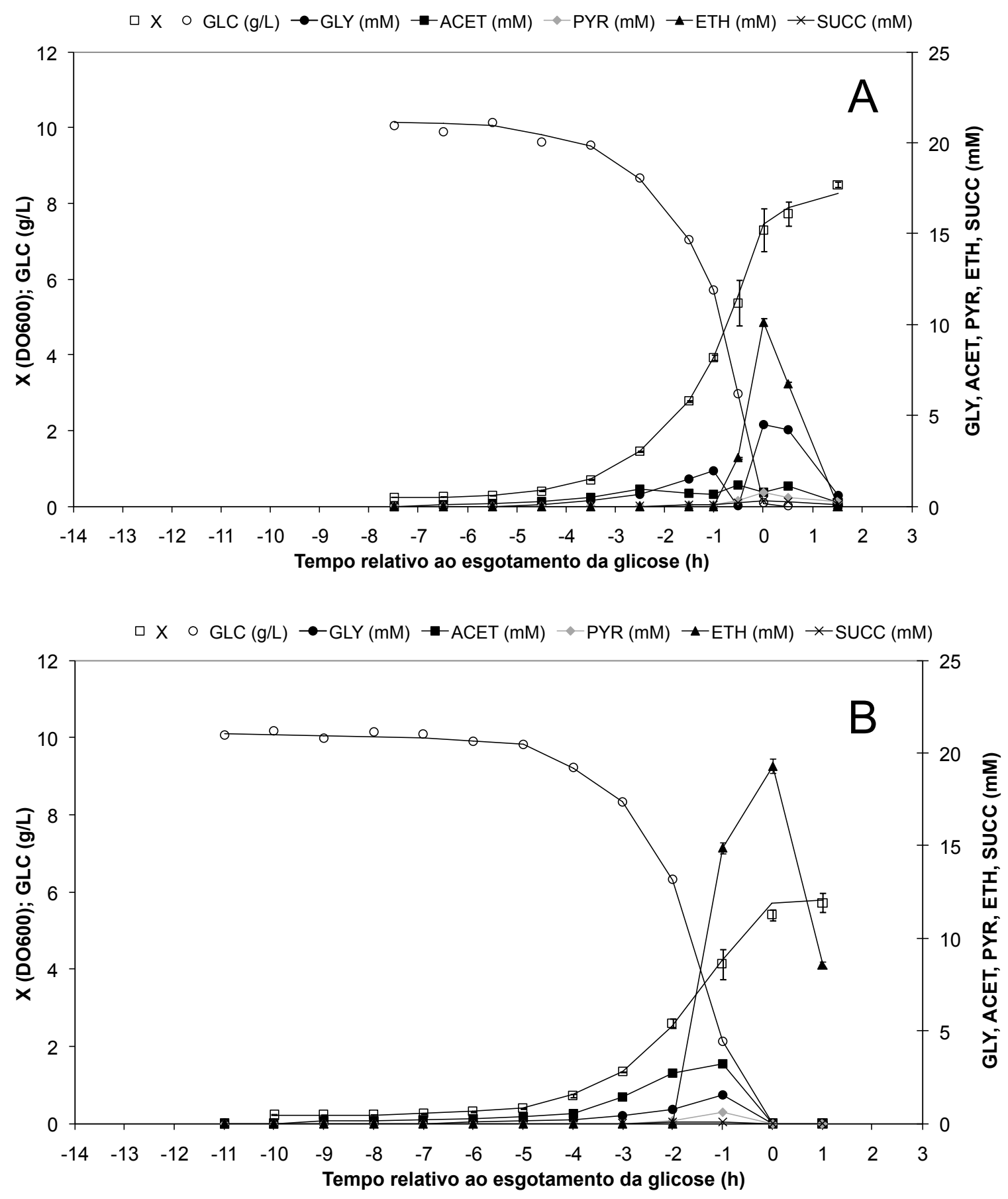

Figura A.3. Curvas de crescimento e formação de metabólitos de (A) K. marxianus CBS 6556 e (B) K. marxianus CBS 397 utilizando glicose $(10 \mathrm{~g} / \mathrm{L})$ como fonte de carbono a $37{ }^{\circ} \mathrm{C}$. Legenda: $(\mathrm{X})$ concentração celular (Absorbância a 600 nm); (GLC) glicose (g/L); (GLY, ACET, PYR, ETH, SUCC) glicerol, acetato, piruvato, etanol, succinato $(\mathrm{mM})$, respectivamente. Os pontos apresentados são os valores médios determinados a partir de dois cultivos isolados. 
$\square \mathrm{X} \quad \circ \mathrm{GLC}(\mathrm{g} / \mathrm{L}) \rightarrow \mathrm{GLY}(\mathrm{mM}) \rightarrow \mathrm{ACET}(\mathrm{mM}) \rightarrow \mathrm{PYR}(\mathrm{mM}) \rightarrow \mathrm{ETH}(\mathrm{mM}) \rightarrow \mathrm{SUCC}(\mathrm{mM})$

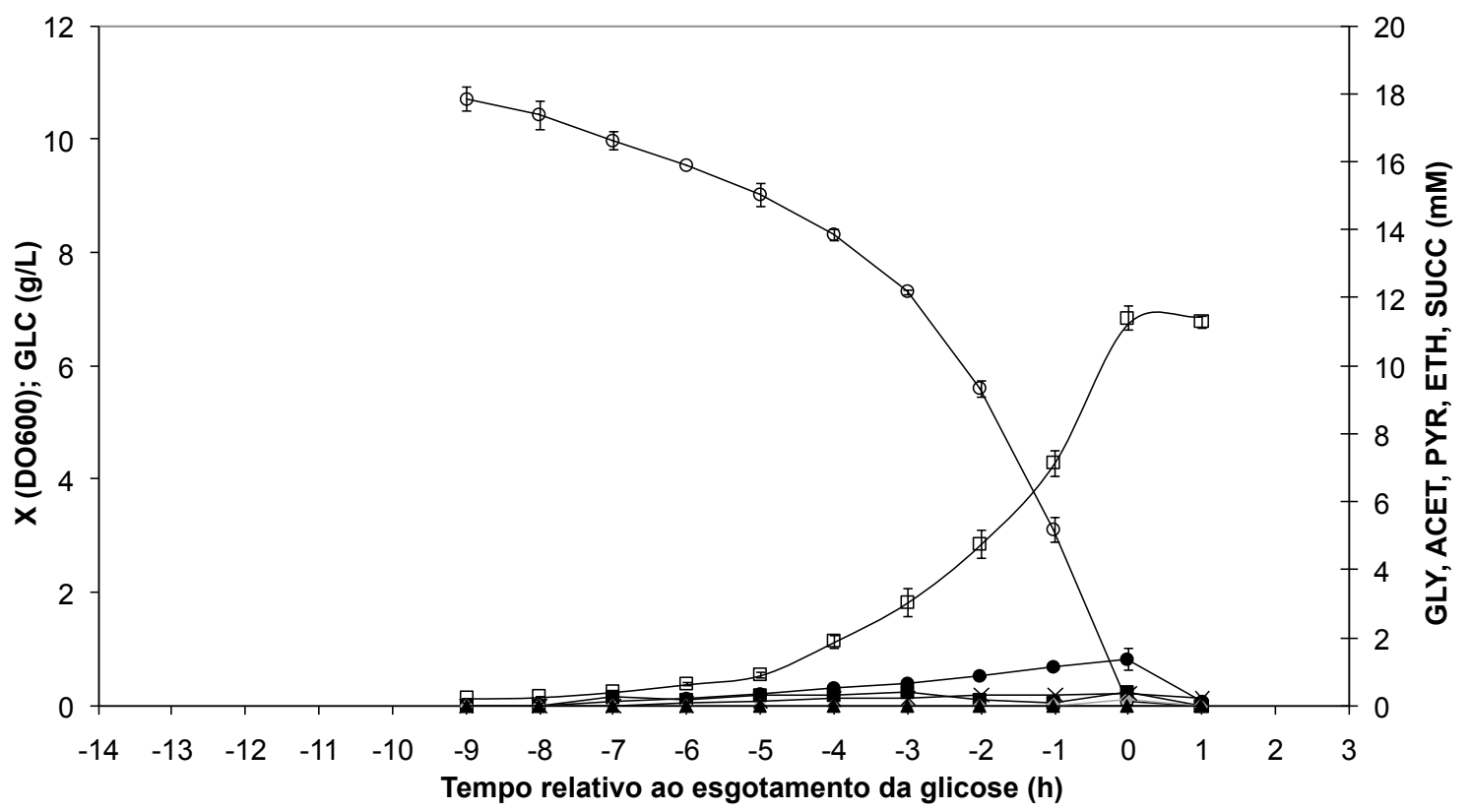

Figura A.4. Curvas de crescimento e formação de metabólitos de K. marxianus CBS 712 utilizando glicose $(10 \mathrm{~g} / \mathrm{L})$ como fonte de carbono a $37^{\circ} \mathrm{C}$. Legenda: (X) concentração celular (Absorbância a $600 \mathrm{~nm}$ ); (GLC) glicose (g/L); (GLY, ACET, PYR, ETH, SUCC) glicerol, acetato, piruvato, etanol, succinato (mM), respectivamente. Os pontos apresentados são os valores médios determinados a partir de dois cultivos isolados. 
$\square \mathrm{X} \quad \circ \mathrm{LAC}(\mathrm{g} / \mathrm{L}) \longrightarrow \mathrm{LAC}$ alis $-\mathrm{ACET}(\mathrm{mM}) \rightarrow \mathrm{PYR}(\mathrm{mM}) \rightarrow \mathrm{ETH}(\mathrm{mM}) \quad$ - SUCC $(\mathrm{mM})$
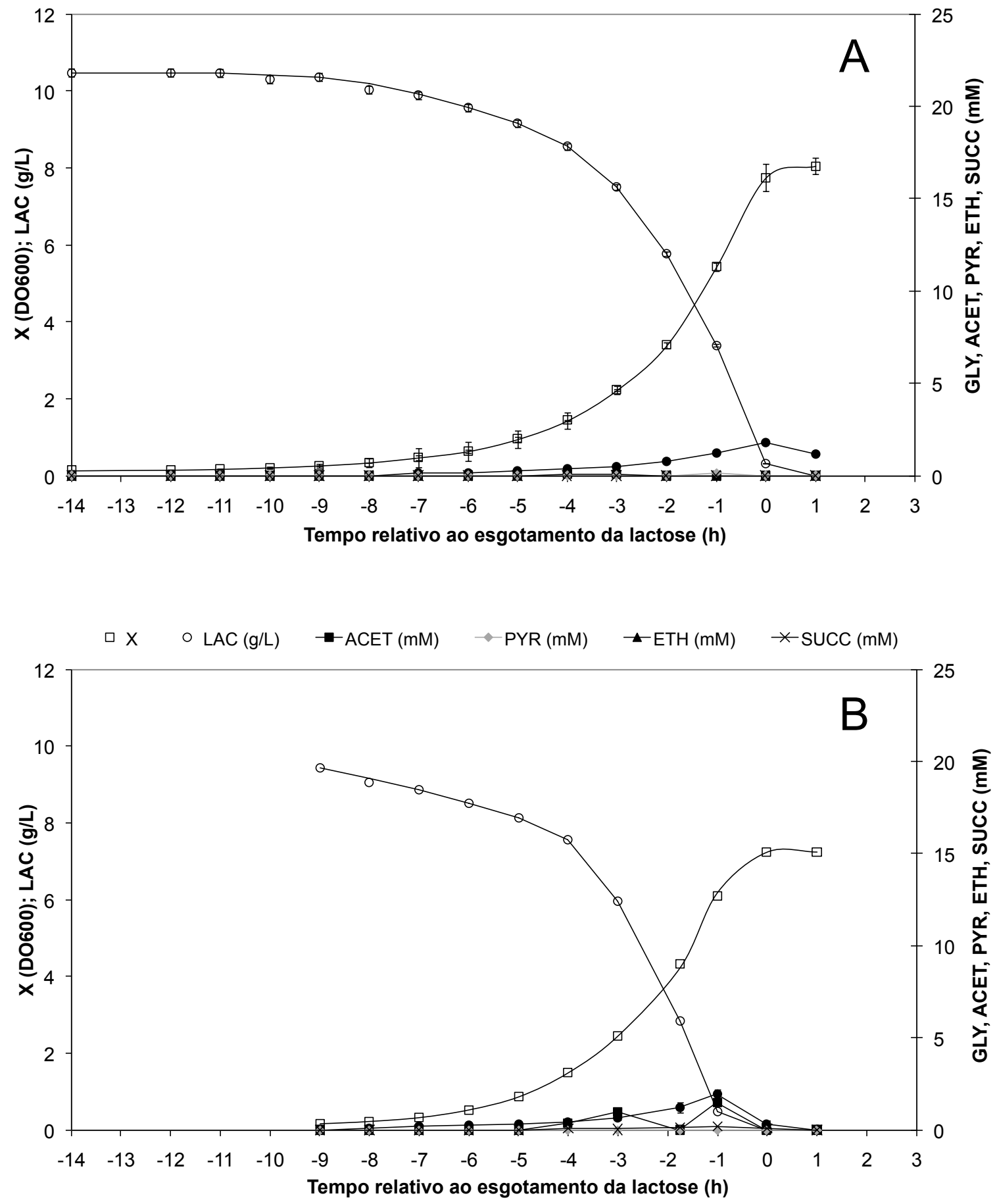

Figura A.5. Curvas de crescimento e formação de metabólitos de (A) K. marxianus CBS 6556 e (B) K. marxianus CBS 397 utilizando lactose $(10 \mathrm{~g} / \mathrm{L})$ como fonte de carbono a $30{ }^{\circ} \mathrm{C}$. Legenda: $(\mathrm{X})$ concentração celular (Absorbância a $600 \mathrm{~nm}$ ); (GLC) glicose (g/L); (GLY, ACET, PYR, ETH, SUCC) glicerol, acetato, piruvato, etanol, succinato $(\mathrm{mM})$, respectivamente. Os pontos apresentados são os valores médios determinados a partir de dois cultivos isolados. 

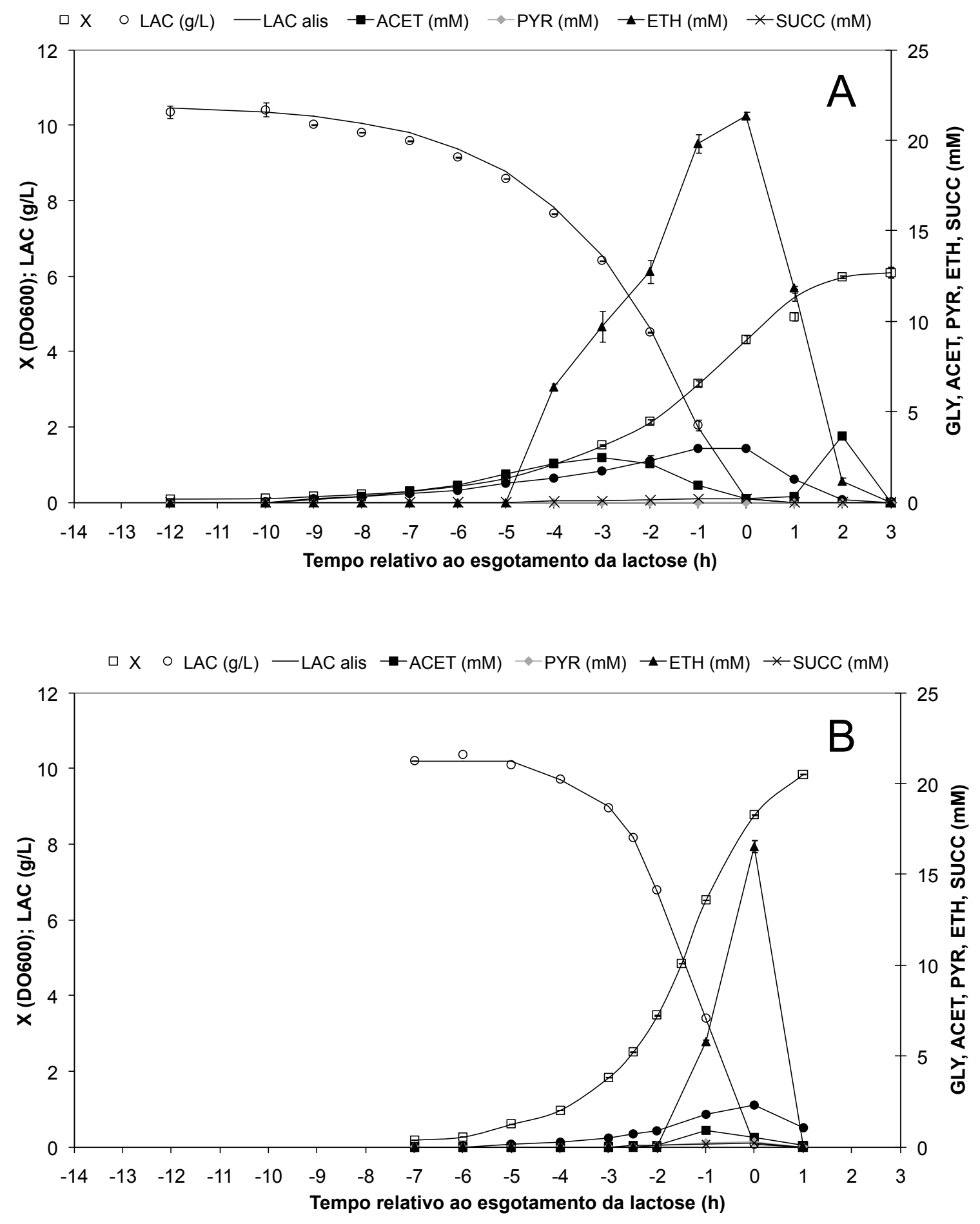

Figura A.6. Curvas de crescimento e formação de metabólitos de (A) K. lactis CBS 2359 e (B) K. marxianus CBS 6556 utilizando lactose $(10 \mathrm{~g} / \mathrm{L})$ como fonte de carbono a (A) $30^{\circ} \mathrm{C}$ e (B) $37^{\circ} \mathrm{C}$. Legenda: (X) concentração celular (Absorbância a $600 \mathrm{~nm}$ ); (GLC) glicose (g/L); (GLY, ACET, PYR, ETH, SUCC) glicerol, acetato, piruvato, etanol, succinato $(\mathrm{mM})$, respectivamente. Os pontos apresentados são os valores médios determinados a partir de dois cultivos isolados. 


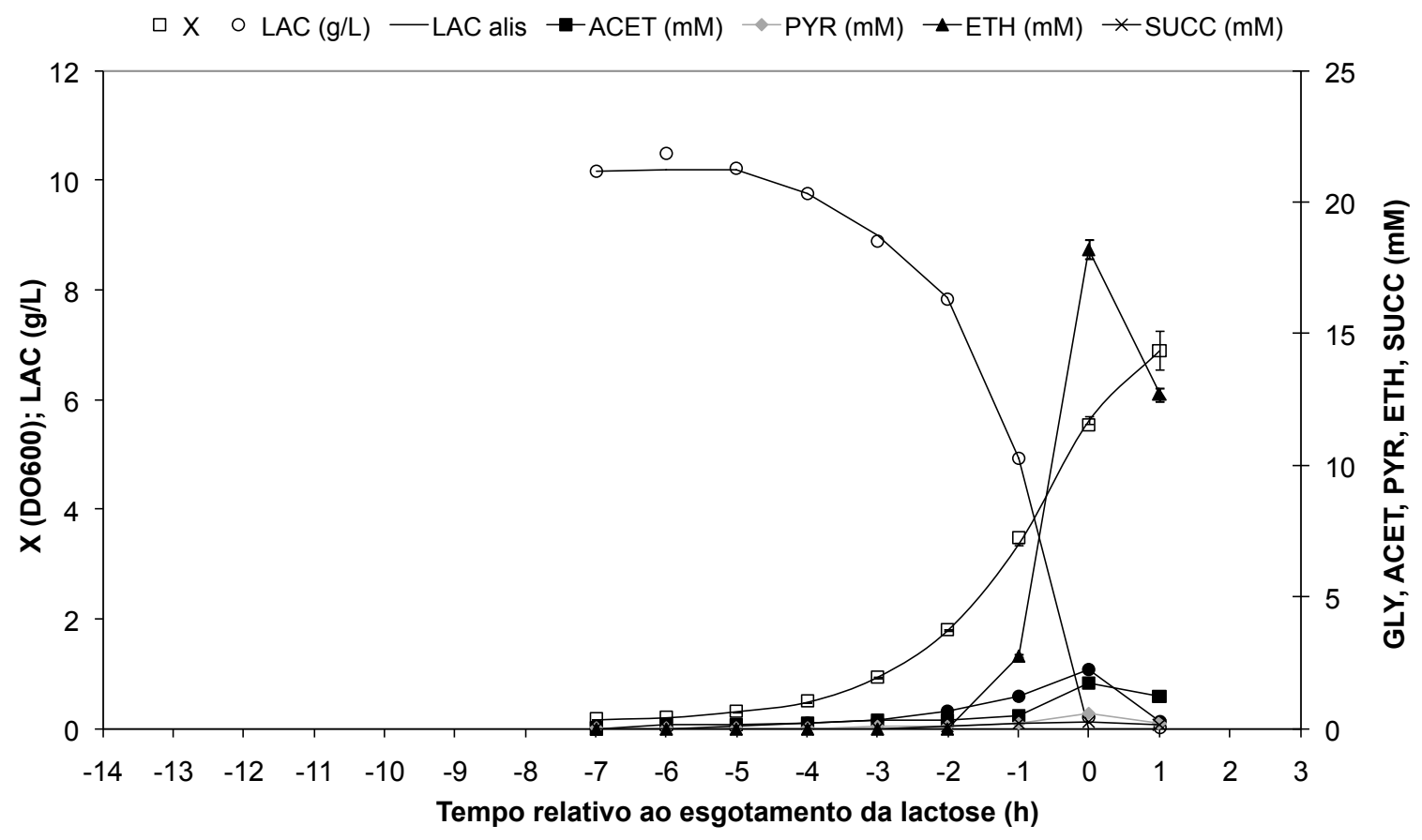

Figura A.7. Curvas de crescimento e formação de metabólitos de K. marxianus CBS 397 utilizando lactose $(10 \mathrm{~g} / \mathrm{L})$ como fonte de carbono a $37^{\circ} \mathrm{C}$. Legenda: (X) concentração celular (Absorbância a $600 \mathrm{~nm}$ ); (GLC) glicose (g/L); (GLY, ACET, PYR, ETH, SUCC) glicerol, acetato, piruvato, etanol, succinato (mM), respectivamente. Os pontos apresentados são os valores médios determinados a partir de dois cultivos isolados. 

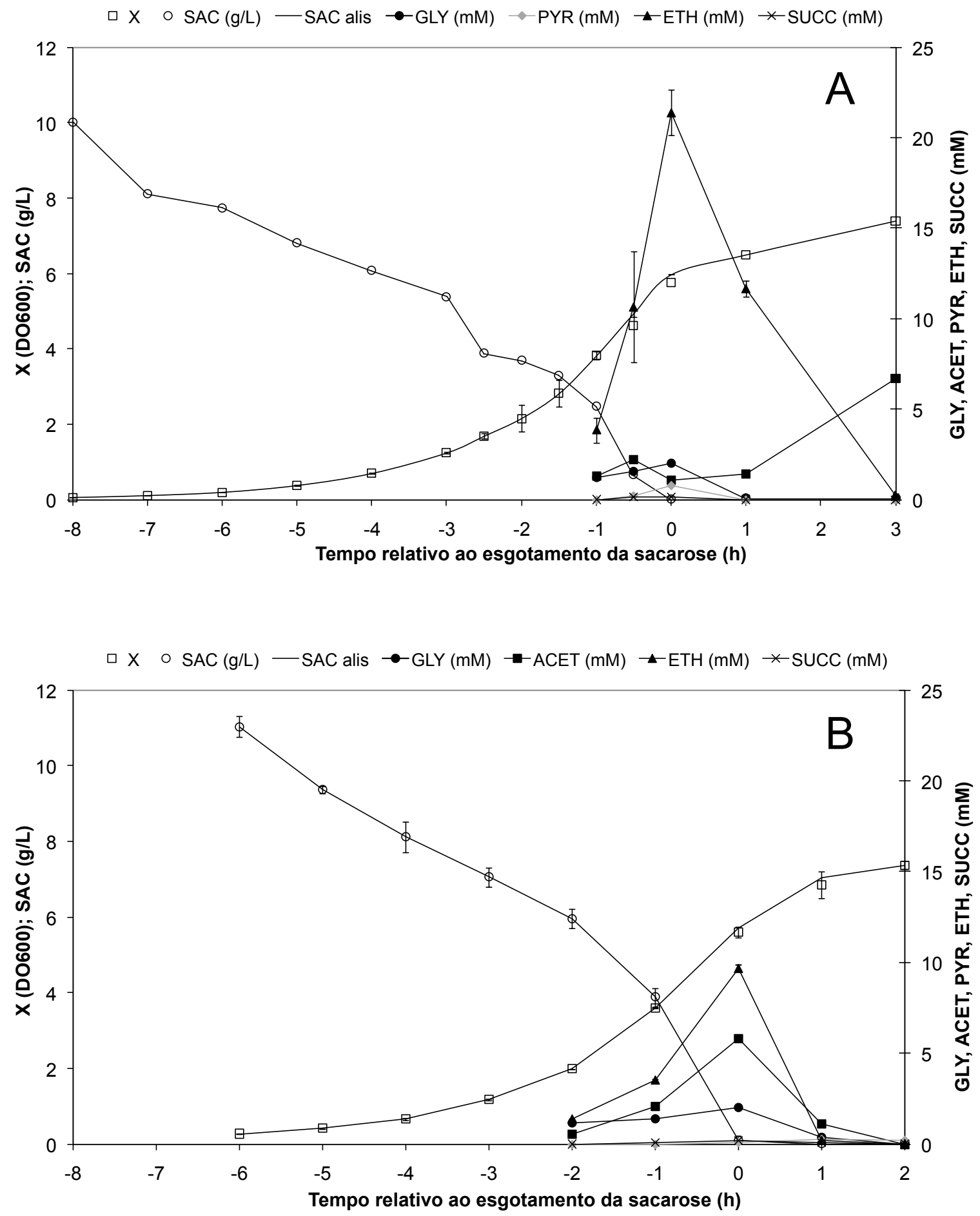

Figura A.8. Curvas de crescimento e formação de metabólitos de (A) K. marxianus CBS 6556 e (B) K. marxianus CBS 397 utilizando sacarose $(10 \mathrm{~g} / \mathrm{L})$ como fonte de carbono a $30{ }^{\circ} \mathrm{C}$. Legenda: $(\mathrm{X})$ concentração celular (Absorbância a $600 \mathrm{~nm}$ ); (GLC) glicose (g/L); (GLY, ACET, PYR, ETH, SUCC) glicerol, acetato, piruvato, etanol, succinato $(\mathrm{mM})$, respectivamente. Os pontos apresentados são os valores médios determinados a partir de dois cultivos isolados. 

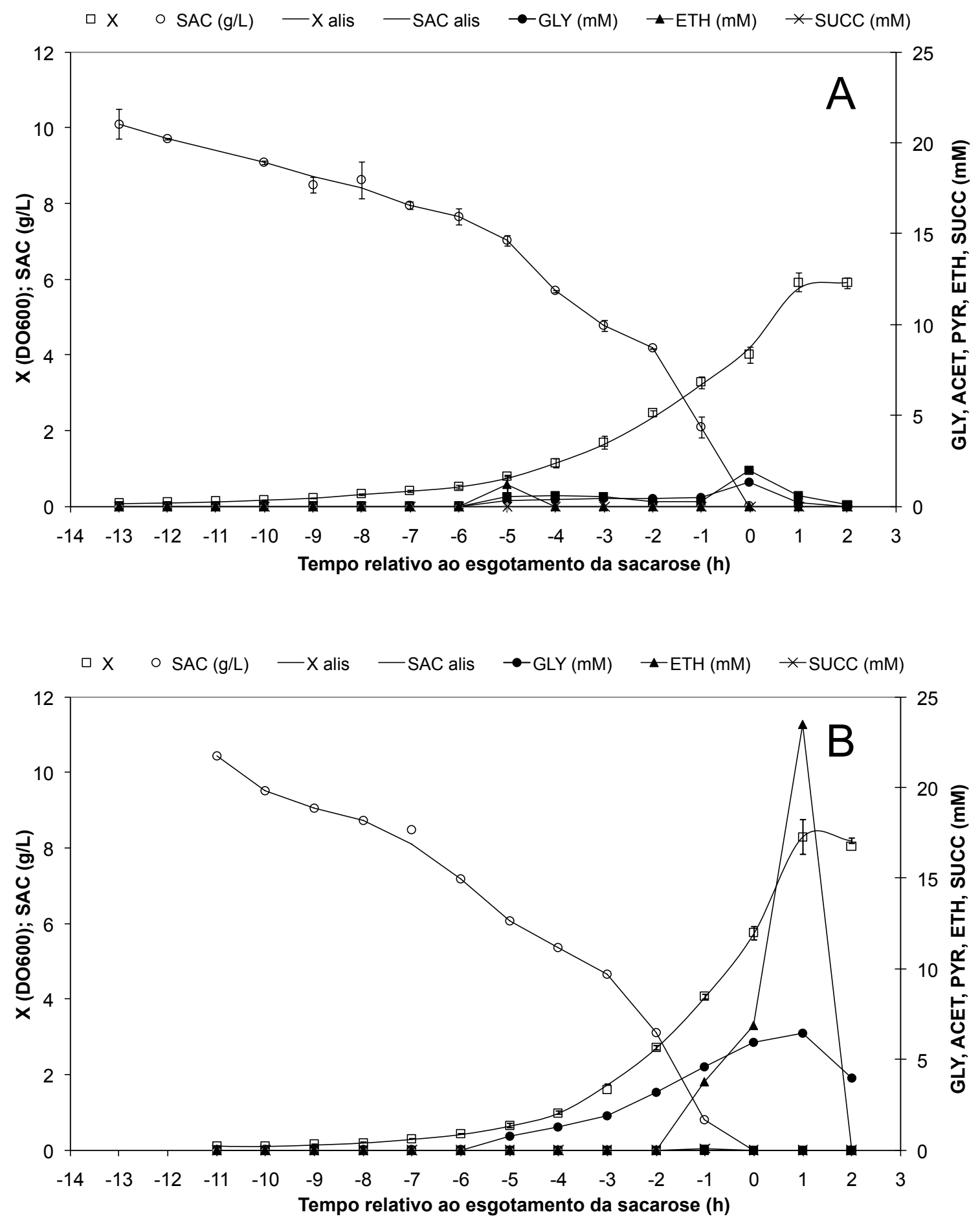

Figura A.9. Curvas de crescimento e formação de metabólitos de (A) K. marxianus CBS 712 e (B) K. lactis CBS 2359 utilizando sacarose $(10 \mathrm{~g} / \mathrm{L})$ como fonte de carbono a $30{ }^{\circ} \mathrm{C}$. Legenda: $(\mathrm{X})$ concentração celular (Absorbância a $600 \mathrm{~nm}$ ); (GLC) glicose (g/L); (GLY, ACET, PYR, ETH, SUCC) glicerol, acetato, piruvato, etanol, succinato $(\mathrm{mM})$, respectivamente. Os pontos apresentados são os valores médios determinados a partir de dois cultivos isolados. 
$\square X \quad \circ \operatorname{SAC}(\mathrm{g} / \mathrm{L}) \longrightarrow \mathrm{SAC}$ alis $\rightarrow \mathrm{GLY}(\mathrm{mM}) \rightarrow$ ACET $(\mathrm{mM}) \rightarrow \mathrm{PYR}(\mathrm{mM}) \rightarrow \mathrm{SUCC}(\mathrm{mM})$

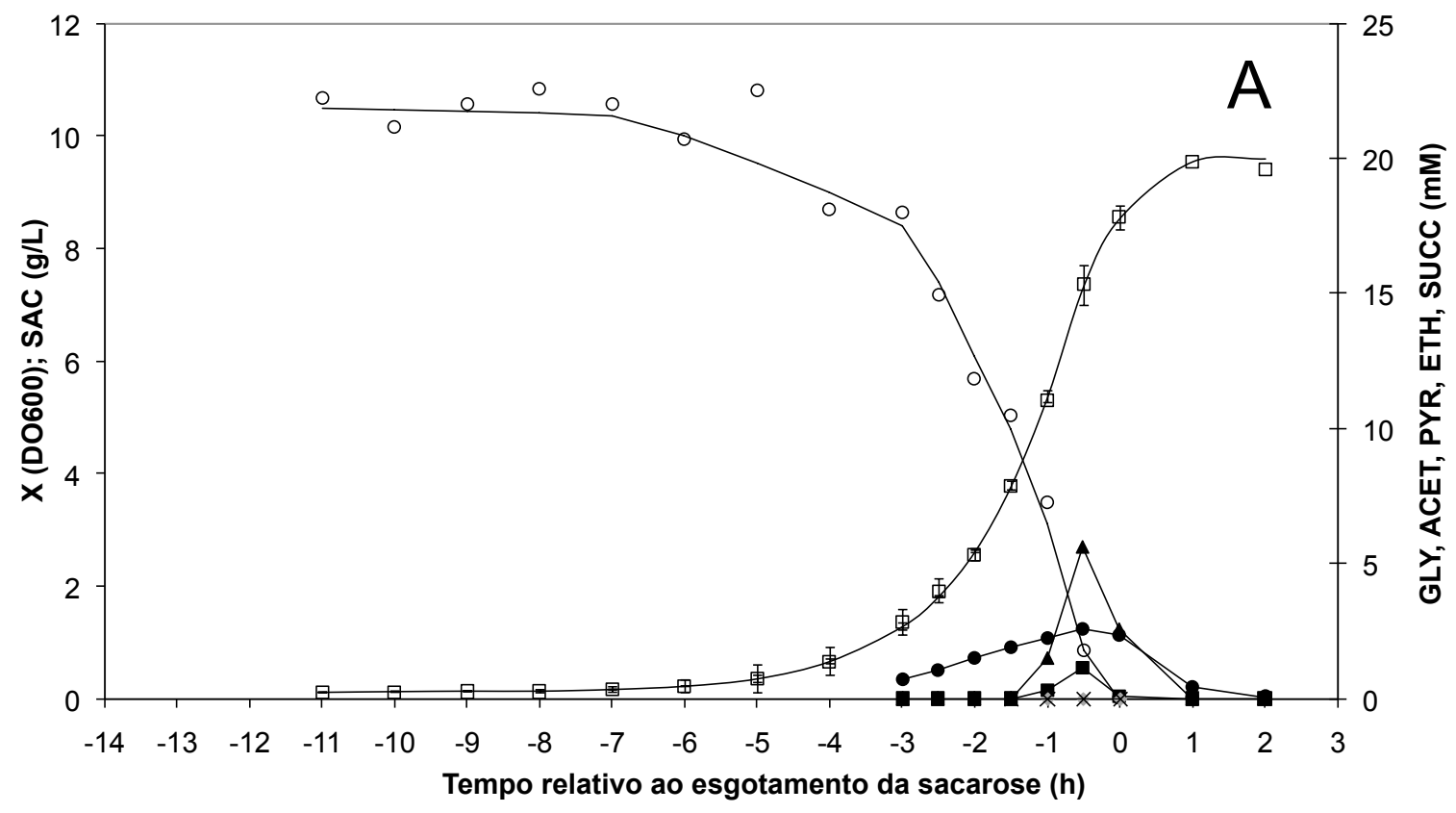

$\square X \circ \operatorname{SAC}(\mathrm{g} / \mathrm{L}) \longrightarrow \mathrm{SAC}$ alis $\rightarrow \mathrm{GLY}(\mathrm{mM}) \rightarrow$ ACET $(\mathrm{mM}) \rightarrow$ PYR $(\mathrm{mM}) \rightarrow \mathrm{SUCC}(\mathrm{mM})$

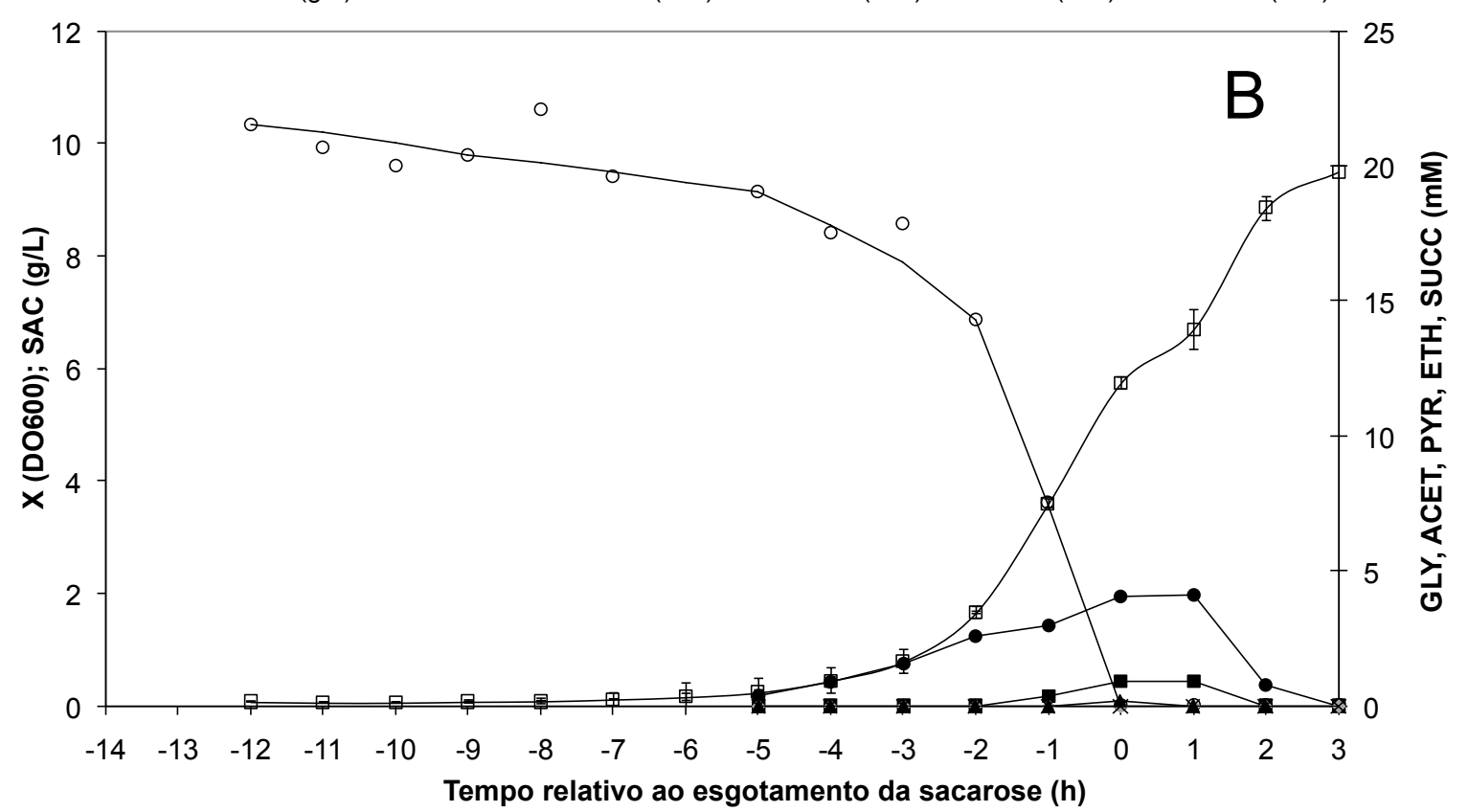

Figura A.10. Curvas de crescimento e formação de metabólitos de (A) K. marxianus CBS 6556 e (B) $K$. marxianus CBS 397 utilizando sacarose (10g/L) como fonte de carbono a $37{ }^{\circ} \mathrm{C}$. Legenda: $(\mathrm{X})$ concentração celular (Absorbância a $600 \mathrm{~nm}$ ); (GLC) glicose (g/L); (GLY, ACET, PYR, ETH, SUCC) glicerol, acetato, piruvato, etanol, succinato $(\mathrm{mM})$, respectivamente. Os pontos apresentados são os valores médios determinados a partir de dois cultivos isolados. 


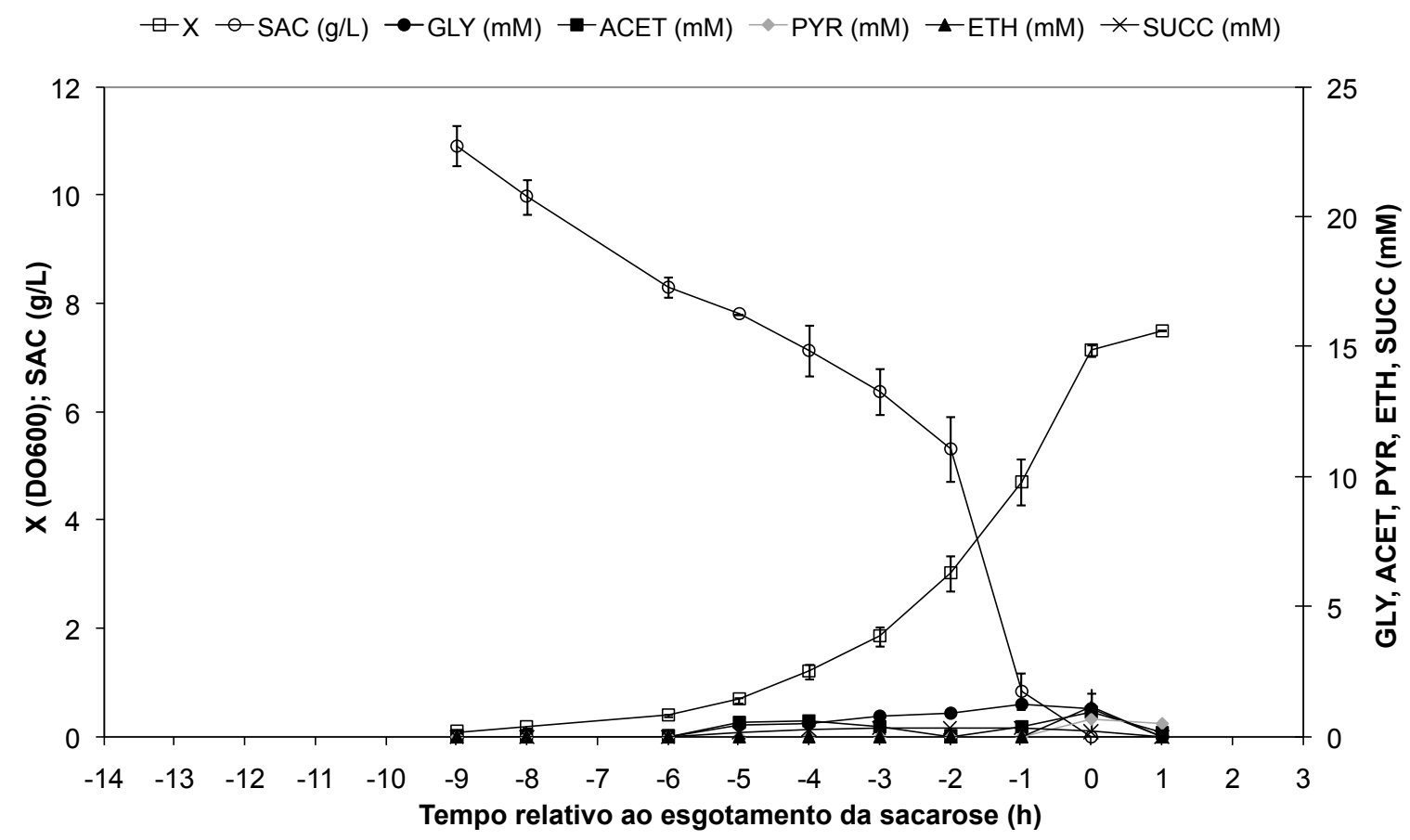

Figura A.11. Curvas de crescimento e formação de metabólitos de K. marxianus CBS 712 utilizando sacarose (10g/L) como fonte de carbono a $37^{\circ} \mathrm{C}$. Legenda: (X) concentração celular (Absorbância a $600 \mathrm{~nm}$ ); (GLC) glicose (g/L); (GLY, ACET, PYR, ETH, SUCC) glicerol, acetato, piruvato, etanol, succinato (mM), respectivamente. Os pontos apresentados são os valores médios determinados a partir de dois cultivos isolados. 


\section{APÊNDICE B - GRÁFICOS DAS CINÉTICAS DE FORMAÇÃO DE INULINASE EM K. marxianus}
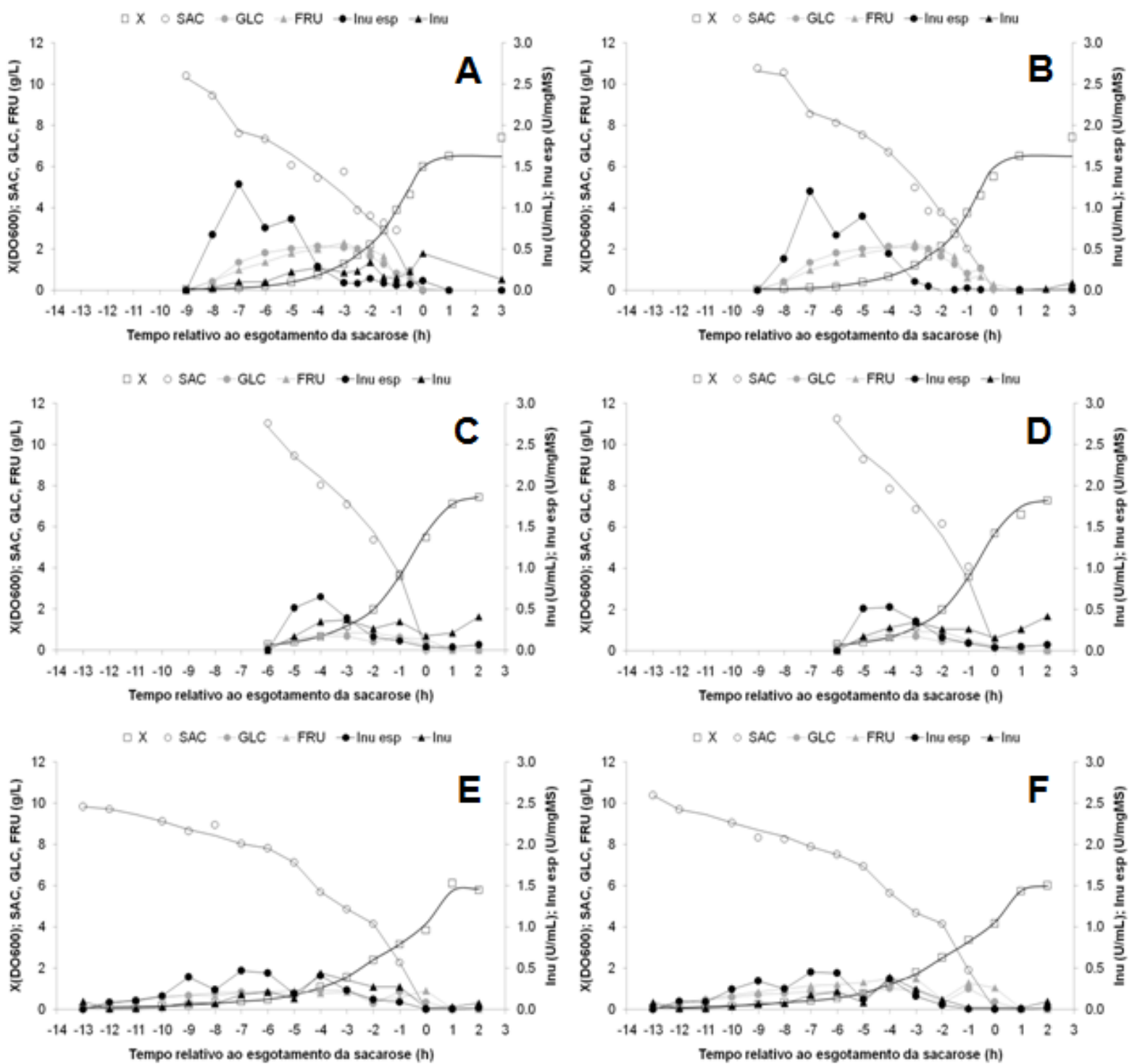

Figura B.1. Curvas de crescimento (das duas repetições de cada condição), consumo e hidrólise da sacarose e formação de inulinase de K.marxianus a $30^{\circ} \mathrm{C}$. (A e B) $K$. marxianus CBS 6556. (C e D) K. marxianus NRRLy2415. (E e F) K .marxianus PYCC 3886. Legenda: (X) concentração celular (DO600); (SAC) sacarose (g/L); (GLC) glicose (g/L); (FRU) frutose (g/L); (Inu esp) Atividade específica de inulinase extracelular (U/mgMS); (Inu) Atividade de inulinase extracelular $(\mathrm{U} / \mathrm{mL})$. 

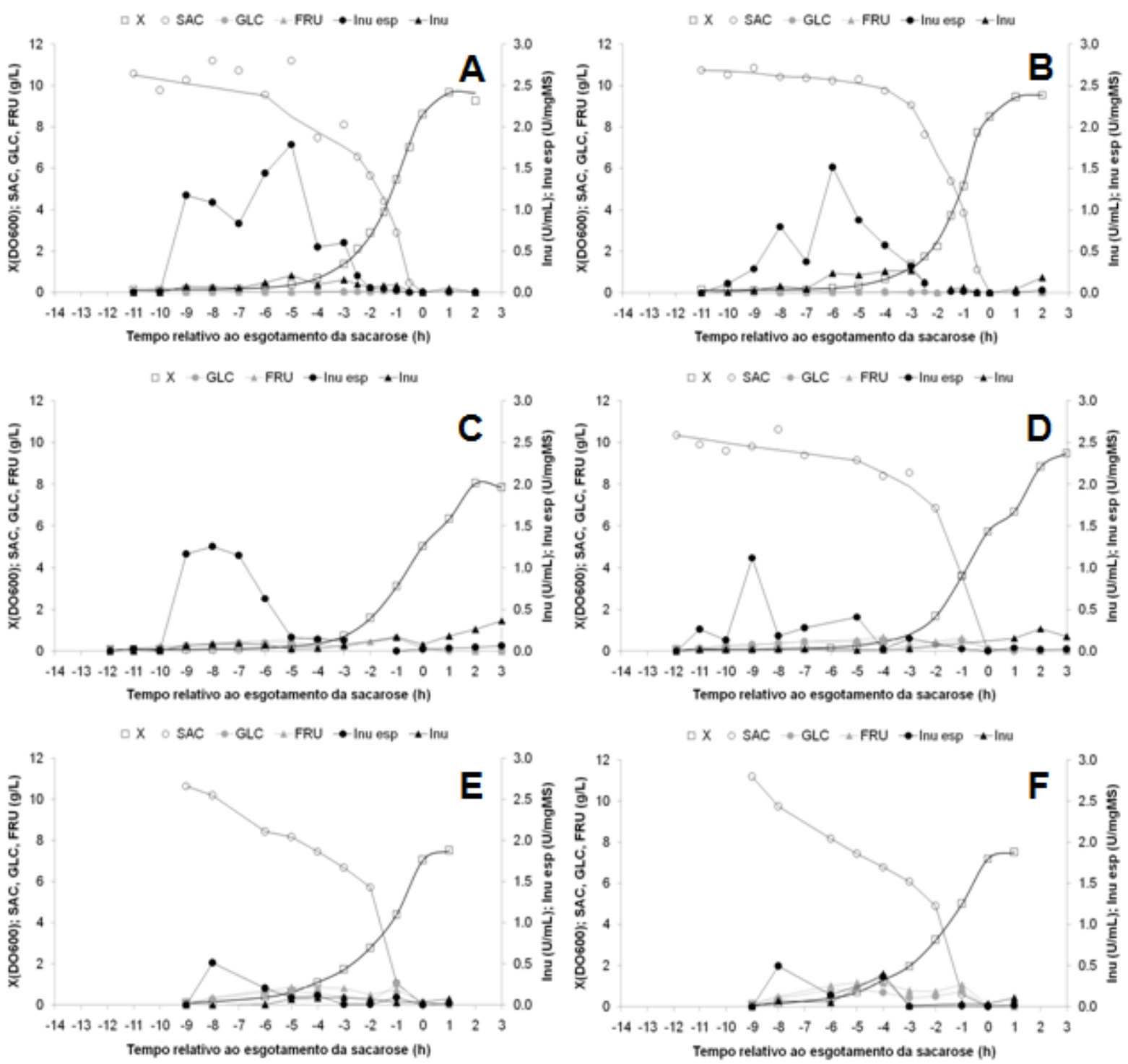

Figura B.2. Curvas de crescimento (das duas repetições de cada condição), consumo e hidrólise da sacarose e formação de inulinase de K.marxianus a $37^{\circ} \mathrm{C}$. (A e B) $K$. marxianus CBS 6556. (C e D) $K$. marxianus NRRLy2415. (E e F) K .marxianus PYCC 3886. Legenda: (X) concentração celular (DO600); (SAC) sacarose (g/L); (GLC) glicose (g/L); (FRU) frutose (g/L); (Inu esp) Atividade específica de inulinase extracelular (U/mgMS); (Inu) Atividade de inulinase extracelular $(\mathrm{U} / \mathrm{mL})$. No diagrama C, a sacarose não foi determinada. 